\title{
Evaluation of the Furnace Method for the production of low carbon ferrochrome
}

\author{
by
}

\author{
H Weitz
}

\section{Supervisor: AM Garbers-Craig}

\author{
Submitted in partial fulfilment of the requirements for the degree Masters of \\ Engineering in Metallurgical Engineering \\ Department of Materials Science and Metallurgical Engineering \\ Faculty of Engineering, Built Environment and Information Technology \\ University of Pretoria \\ Republic of South Africa
}

Submission date: 10 December 2015 


\section{ABSTRACT}

Low carbon ferrochrome is a primary alloying element in the production of stainless steel. The Mixing Method (Perrin and Duplex) processes are most commonly used for the production thereof. However, during the cocktailing step, process temperatures are extremely high, resulting in rapid deterioration of the ladle refractories and fuming of the products. The high temperature is a result of the exothermic silicothermic reduction reactions. A significant amount of energy is lost to the atmosphere.

The Furnace Method, and in particular the Liquid Feed Furnace Method, has the potential to improve on the shortcomings of the Mixing Method. A techno-economic evaluation was performed on the different process routes to identify whether or not there is merit in choosing one over the other.

The evaluation showed that the capital cost for the methods are comparable, but a saving in the operating cost is achievable when using the Furnace Method instead of the Mixing Method. Savings of 7.3 to $7.9 \%$ were calculated for the Solid Feed Furnace Method and 9.6 to $10.7 \%$ for the Liquid Feed Furnace Method, when compared to the Mixing Method. This is largely due to the lower energy requirement and raw material consumptions for the Furnace Method.

The oxidising conditions in the Mixing Method ore-lime melt furnace, combined with a high slag basicity and high operating temperatures, are very conducive for producing hexavalent chromium, which is severely toxic to humans. Leaching tests, performed on a dust sample from an existing facility that uses the Perrin process, confirmed that a significant amount of $\mathrm{Cr}(\mathrm{VI})$ was produced. This poses a severe health and safety risk, as well as a financial burden to properly neutralise and dispose of any Cr(VI) that has formed. A closed furnace with little to no air ingress is used in the Furnace Method, thereby ensuring a more neutral atmosphere. A lower basicity slag, with a lower liquidus temperature is also used, thereby further decreasing the amount of $\mathrm{Cr}(\mathrm{VI})$ that would be likely to form.

Having established that the Furnace Method has definite advantages over the Mixing Method, the preferred refractory-slag system was identified by means of thermochemical modelling. Different combinations of lime and doloma fluxed slag were modelled with magnesia and doloma refractories. Quartz fluxed slag in contact with an alumina lining was also considered to identify any unexpected benefits.

The required slag liquidus temperature, to be compatible with low carbon ferrochrome alloy (which has a very high liquidus temperature), was determined to be between 1550 and $1700^{\circ} \mathrm{C}$. Modelling showed that a quartz fluxed slag had a liquidus temperature well below this range for a very wide basicity range evaluated. Such a slag would therefore not be suitable. While a doloma fluxed slag had a liquidus temperature within this range, the slag basicity for that range would be very low and not be compatible with any of the two basic refractory systems evaluated. Doloma refractories were also found to suffer severe wear at an operating temperature of $1750^{\circ} \mathrm{C}$, the temperature required to ensure that the alloy is molten. 
The required basicity range for a lime fluxed slag that had a liquidus temperature between 1550 and $1700^{\circ} \mathrm{C}$ was found to be 1.68 to 1.90. The slag only became saturated in $\mathrm{MgO}$ above a slag basicity of 1.99. However, in a commercial-size furnace, the temperature at the refractory hot face would be lower than the process temperature, provided that the slag bath was not excessively turbulent. Sidewall cooling would also assist in maintaining a slag freeze lining. Operating with a slag basicity within the 1.68 to 1.90 range should therefore not pose a severe risk.

As the process will be operated on a semi-batch basis, the variation of the slag and alloy composition throughout the heat could potentially result in a material that is not compatible with the refractory lining. Two scenarios were modelled, where FeSiCr was added to an ore-lime mixture, and vice versa. The first was found not to be detrimental to the refractories, but there is a concern regarding the high liquidus temperature of the ore-lime melt at the start of the heat. For the second scenario, magnesium was found to report to the gas and alloy phases at the start of the heat. This is of great concern as it would severely damage the refractory lining. To utilise as much of the exothermic energy as possible, while ensuring the integrity of the refractory lining, it was suggested to feed a portion of the ore-lime mixture first, followed by all of the FeSiCr before feeding the remainder of the ore-lime mixture. Feeding crushed, solid FeSiCr allows for better control. However, the latent heat and sensible heat of the FeSiCr would not be utilised.

Smelting tests were performed with samples that had slag target basicities of 1.5 and 2.0 to investigate the phases that were formed and the severity of the slag-refractory interaction. The composition of the slag with a basicity of 1.5 corresponded well with that predicted by the thermochemical model, while the slag composition for a target basicity of 2.0 was very variable. This was due to the high solids content in the slag, which was operated close to its liquidus temperature. The slag CrO content was much lower and the alloy Cr content much higher for both tests, when compared to the values predicted by modelling. The extent to which the reduction reactions occurred was therefore higher than predicted by modelling. The reasons for this would have to be verified by analysing the mechanism by which the reactions occur.

The complete dissolution of a refractory disc that was placed in the mixture for the test with a slag target basicity of 1.5, along with slag penetration into the high density magnesia crucible, indicates that the 1.5 basicity slag was not compatible with the magnesia. This is in agreement with the model. Although the refractory disc was still discernable for the test at a slag target basicity of 2.0, it was severely worn. Slag penetration into the high density magnesia crucible was also evident. A freeze lining would therefore always be required.

The Furnace Method can be considered as a suitable alternative to the Mixing Method. However, care should be taken to control the slag basicity in the region of 1.70 and a freeze lining should be maintained to protect the refractories. The batch feed sequence is also critical to find a balance between having a liquid slag, while still retaining refractory integrity. 


\section{ACKNOWLEDGEMENTS}

I would like to express my sincere gratitude to my supervisor, Prof. Andrie GarbersCraig, for the valuable guidance and motivation that she provided throughout the study. Her commitment to the project and her support helped me to grow both professionally and personally.

Besides my supervisor, I would like to thank Dr. Robert Cromarty for his assistance with the laboratory experiments and for our discussions about the project. I would also like to thank Prof. Johan de Villiers, Dr. Johan Zietsman and Mr. Markus Erwee for their insights and guidance, as well as Mr. Carel Coetzee, Mr. Caleb Kweto, Ms. Wiebke Grote and Ms. Jeanette Dykstra for their assistance with the SEM, leaching tests, XRD and XRF analyses respectively.

My sincere thanks also go to my colleagues, especially Jacques Beylefeld, Ted Fulton and Tom Curr, for motivating me to commence with this study and for laying the foundation of the project.

Last but not least, I would like to thank my wife Marélene and my children, Micah and Kaleb, for supporting me and enduring the time spent apart while completing this study. I am truly blessed. Finally I would also like to thank the rest of my family and friends for their encouragement and prayers. 


\section{TABLE OF CONTENTS}

1 INTRODUCTION 1

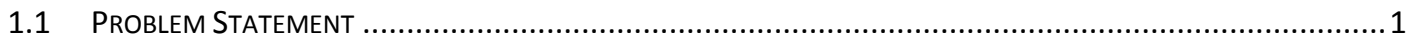

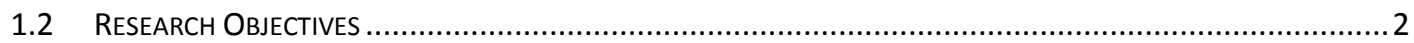

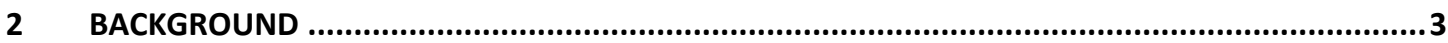

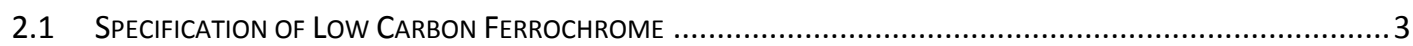

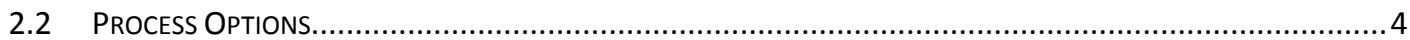

2.2.1 Carbothermic Reduction of Chromite Ore.................................................................... 4

2.2.2 Metallothermic Reduction of Chromite Ore............................................................. 6

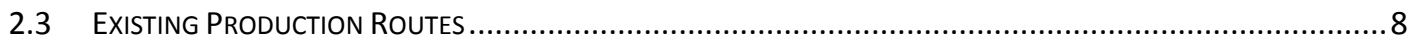

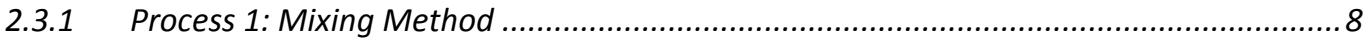

2.3.1.1 Mixing Method: Perrin Process ..................................................................................

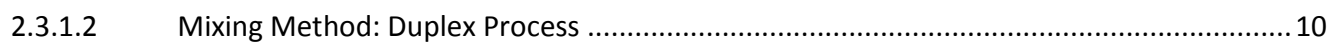

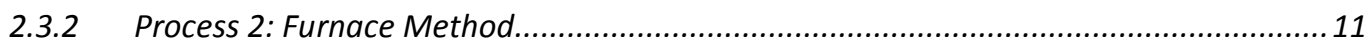

2.3.2.1 Solid Feed Furnace Method (SFFM) ………………..................................................11

2.3.2.2 Liquid Feed Furnace Method (LFFM) ……………………………………………....12

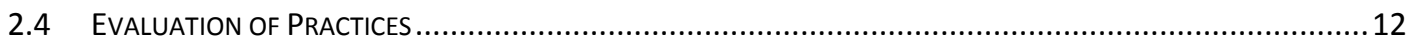

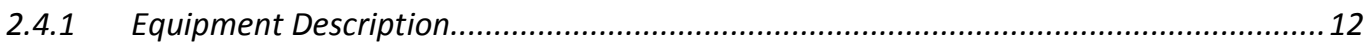

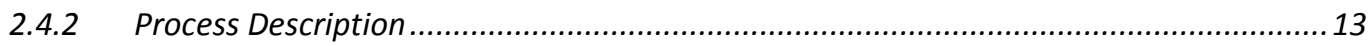

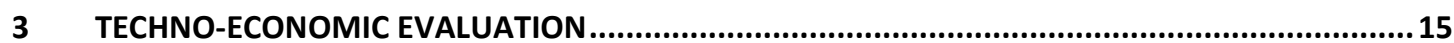

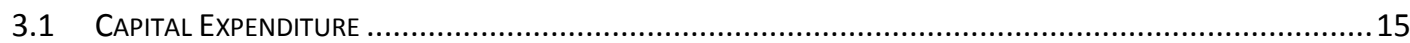

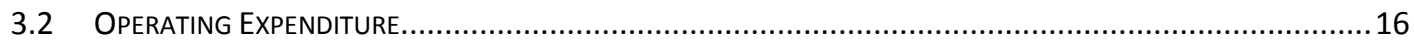

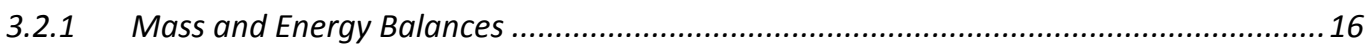

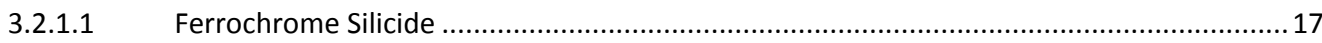

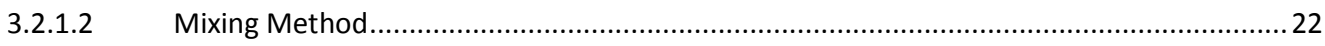

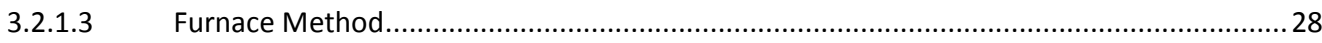

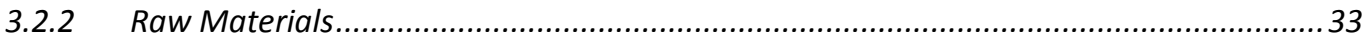

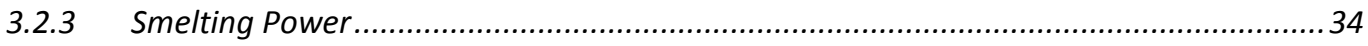

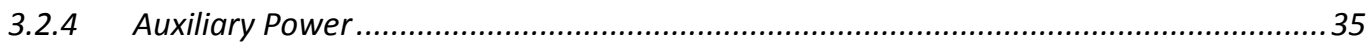

3.2.5 Operational Labour...............................................................................................

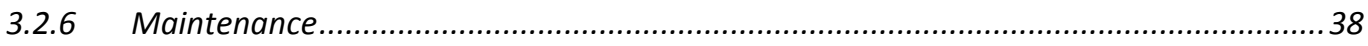

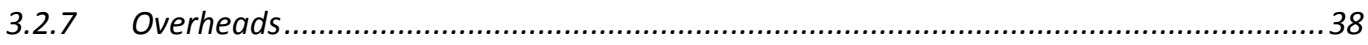

3.2.8 Exclusions

Page iv

(C) University of Pretoria 
3.3.1 Cr(VI) Legislation........................................................................................ 41

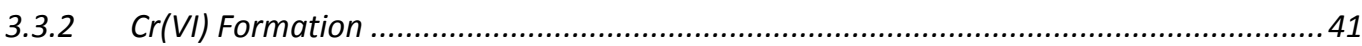

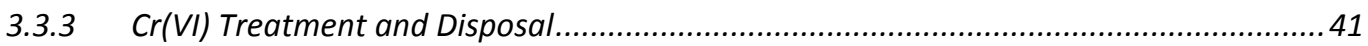

3.3.4 Comparison of $\mathrm{Cr}(\mathrm{VI})$ Formation for Processes ........................................................ 43

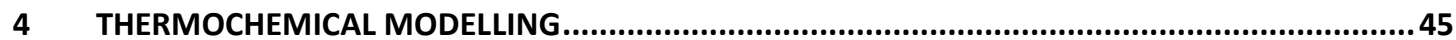

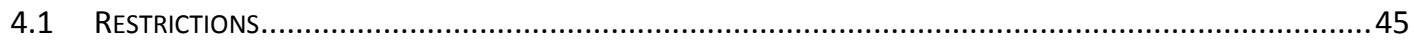

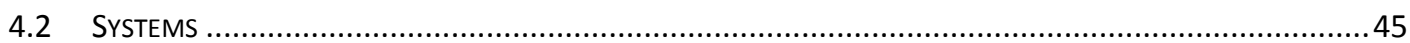

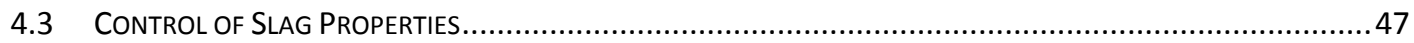

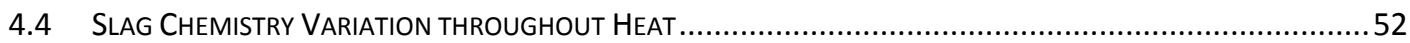

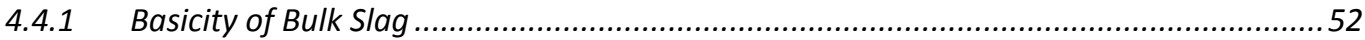

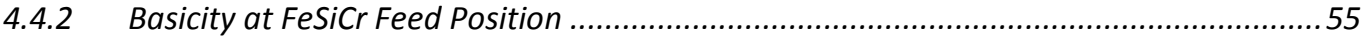

4.4.2.1 Addition of FeSiCr to Ore-Lime Mixture ......................................................................... 55

4.4.2.2 Addition of Ore-Lime Mixture to FeSiCr ..............................................................................57

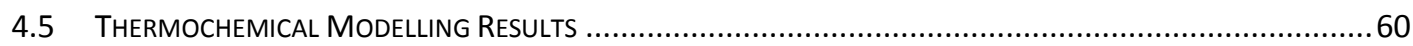

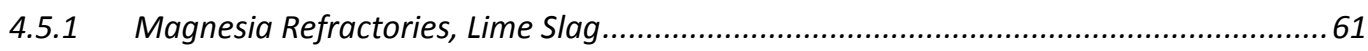

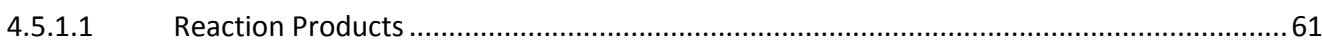

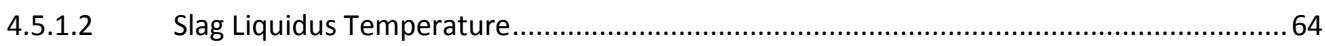

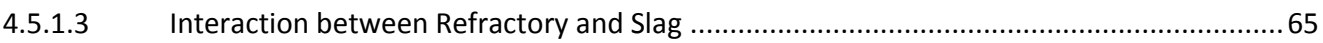

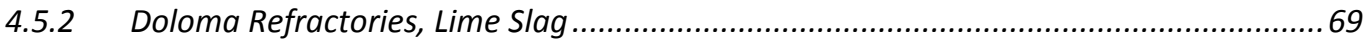

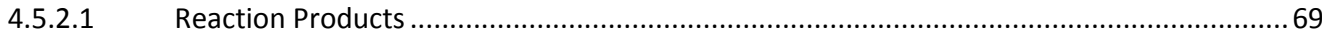

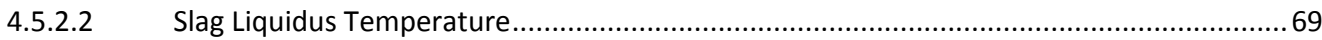

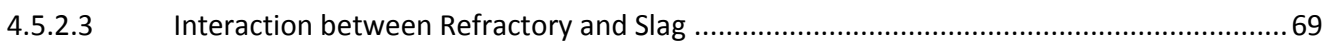

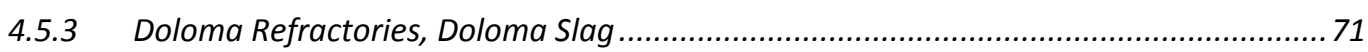

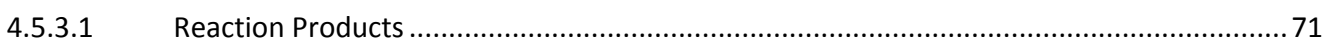

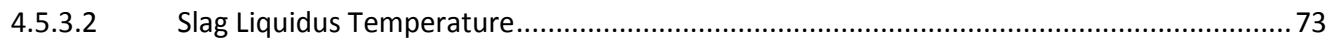

4.5.3.3 Interaction between Refractory and Slag ................................................................... 76

4.5.4 Magnesia Refractories, Doloma Slag.................................................................. 77

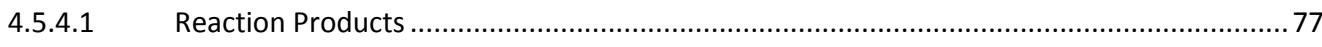

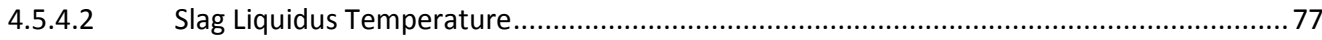

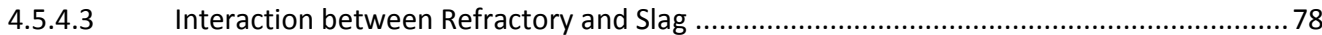

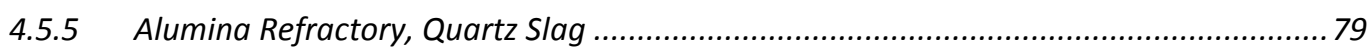

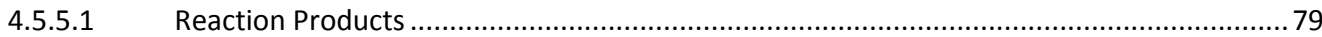

\section{Page v}




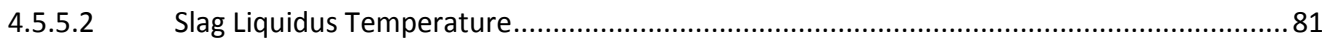

Interaction between Refractory and Slag ......................................................... 83

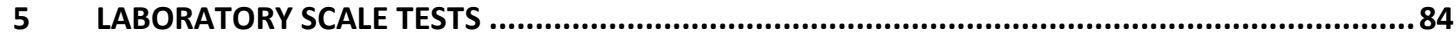

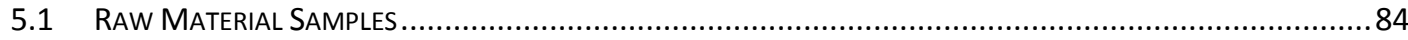

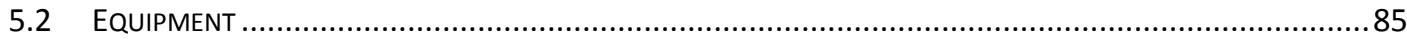

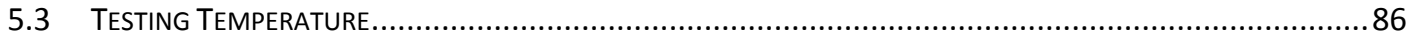

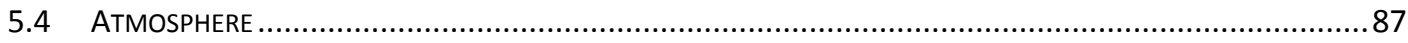

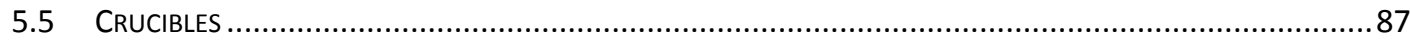

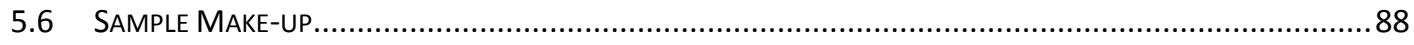

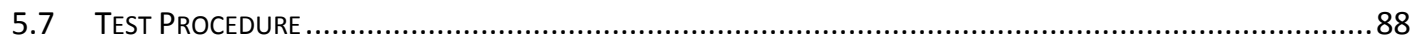

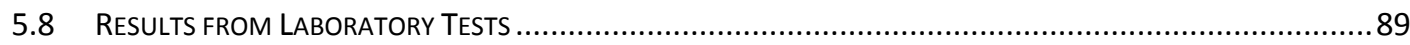

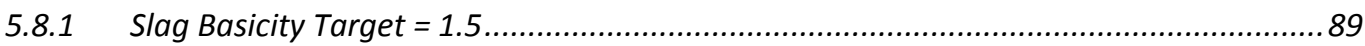

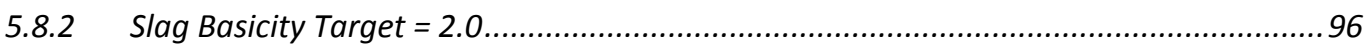

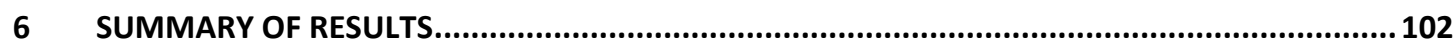

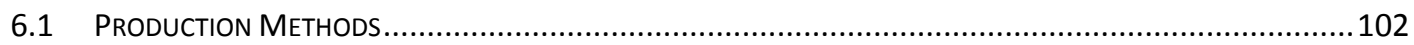

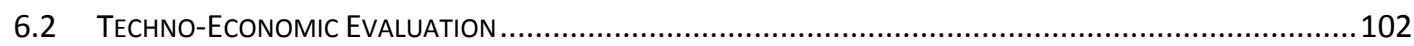

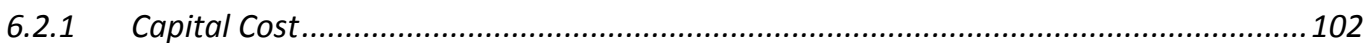

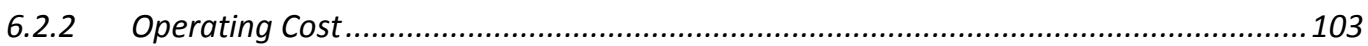

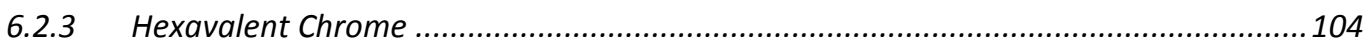

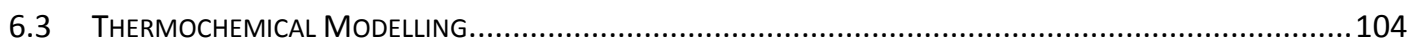

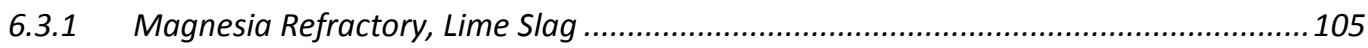

6.3.2 Doloma Refractory ............................................................................................. 106

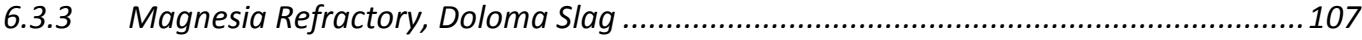

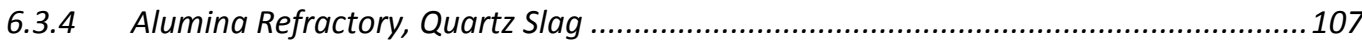

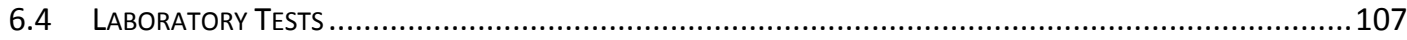

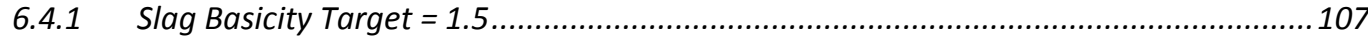

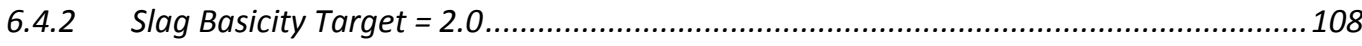

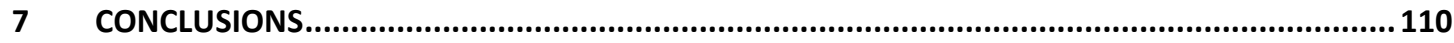

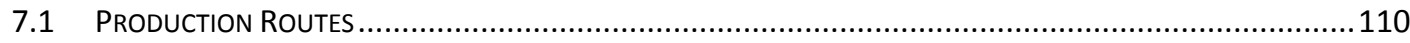

7.2 TECHNO-ECONOMIC EVALUATION ....................................................................................... 110

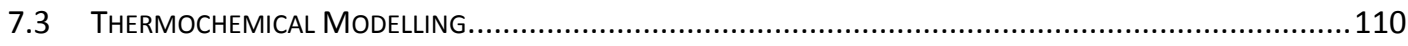

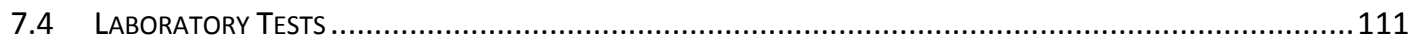

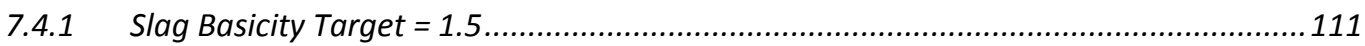

Page vi

(C) University of Pretoria 
7.4.2 Slag Basicity Target $=2.0$.

7.4.3 Comparison of Modelling and Test Work Results.

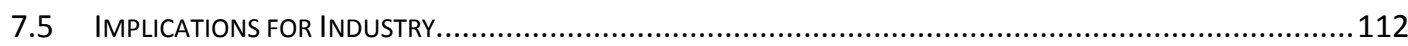

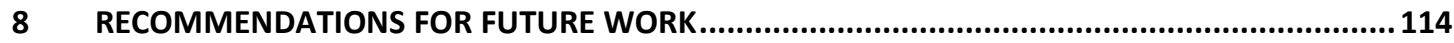

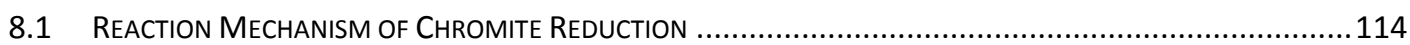

8.2 Aluminium as Alternative to Ferrochrome Silicide.......................................................... 114

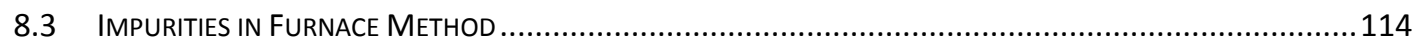

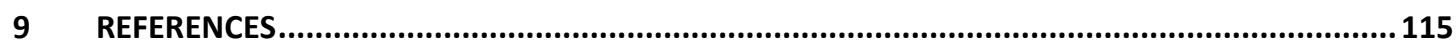

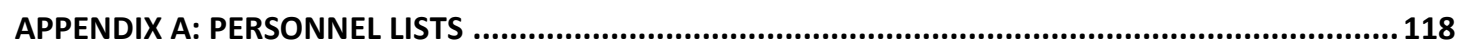

APPENDIX B: THERMOCHEMICAL MODELLING METHODOLOGY ............................................. 120

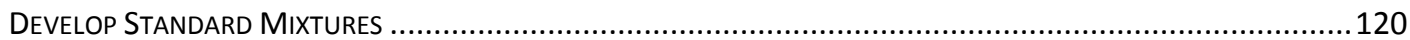

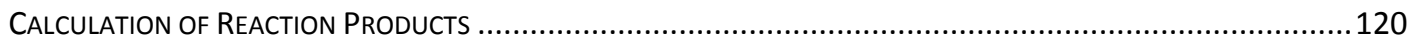

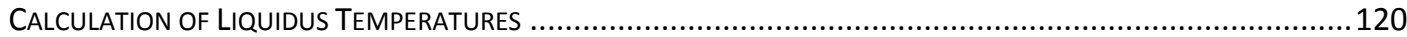

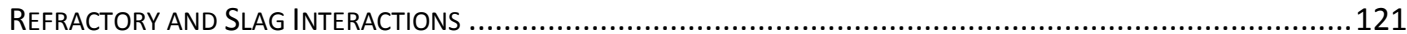

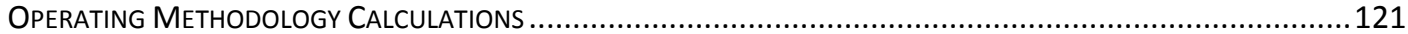

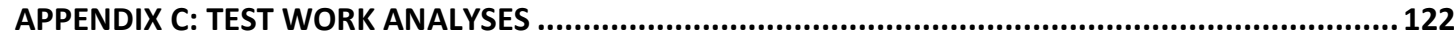

Page vii

(C) University of Pretoria 


\section{List of Tables}

Table 1: Metal consumption for Cr production.

Table 2: Comparison between capital expense items for the Mixing and Furnace Methods.

Table 3: FeSiCr Analysis used in Modelling.

Table 4: Assumptions for FeSiCr mass and energy balance.

Table 5: FeSiCr mass and energy balance.

Table 6: FeSiCr production parameters from literature.

Table 7: Assumptions for Mixing Method mass and energy balances.

Table 8: Mixing Method (Perrin Process) mass and energy balance.

Table 9: Mixing Method (Duplex Process) mass and energy balance. 26

Table 10: LC FeCr production parameters from literature. 27

Table 11: Assumptions for Furnace Method mass and energy balances. 31

Table 12: Solid Feed Furnace Method mass and energy balance. 32

Table 13: Liquid Feed Furnace Method mass and energy balance. 33

Table 14: Raw material unit costs. 34

Table 15: Raw material consumption and cost for all process options. 34

Table 16: Smelting energy consumption and cost for all process options. 35

Table 17: Auxiliary energy consumption and cost for all process options. 36

Table 18: Salary data for South Africa and Australia (USD) (PayScale Inc., 2015).. 37

Table 19: Operating cost range for LC FeCr production. 39

Table 20: Slag-refractory systems modelled. 46

Table 21: Doloma analysis. 46

Table 22: FeSiCr Analysis used in Modelling. 48

Table 23: Composition of final LC FeCr slag with no fluxing. 48

Table 24: Slag liquidus temperature for different fluxes and basicities. 51

Table 25: Starting ore-lime mixture analysis to which FeSiCr was added. 56

Table 26: Typical slag composition for Mixing Method operation.

Table 27: Reaction products from thermochemical modelling, lime flux, temperature $=$ $1750^{\circ} \mathrm{C}$.

Table 28: Lime slag liquidus temperature for different basicities. 64

Table 29: Reaction products from thermochemical modelling, doloma flux, temperature $=1750^{\circ} \mathrm{C}$. 
Table 30: Doloma slag liquidus temperature for different basicities.

Table 31: Reaction products from thermochemical modelling, quartz flux, temperature $=1750^{\circ} \mathrm{C}$. 80

Table 32: Quartz slag liquidus temperature for different basicities. 82

Table 33: Chromite Concentrate and Ferrochrome Silicide sample analysis. 85

Table 34: Sample make-up. 88

Table 35: SEM-EDS analysis of slag matrix, compared with model $(B=1.5)$. 91

Table 36: SEM-EDS analysis of MO (dark grey) phase $(B=1.5)$. 91

Table 37: SEM-EDS analysis of alloy particles $(B=1.5)$. 92

Table 38: SEM-EDS analysis of slag that penetrated into magnesia crucible $(B=1.5)$.

Table 39: SEM-EDS analysis of refractory crucible $(B=1.5)$. 95

Table 40: SEM-EDS analysis of slag matrix, compared with model $(B=2.0)$. 97

Table 41: SEM-EDS analysis of MO (dark grey) phase $(B=2.0)$........................... 98

Table 42: SEM-EDS analysis of alloy particles $(B=2.0)$. .99

Table 43: SEM-EDS analysis of refractory disc $(B=2.0)$ 101

Table 44: Summary of mass and energy balances. 103

Table 45: Operational personnel requirements. 118

Table 46: Administrative and other personnel requirements. 119

Table 47: Slag matrix $(B=1.5)$. 122

Table 48: Slag matrix $(B=2.0)$. 122

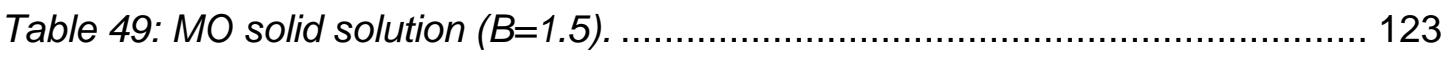

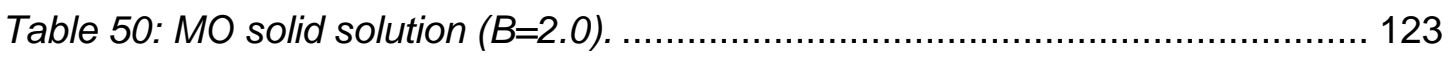

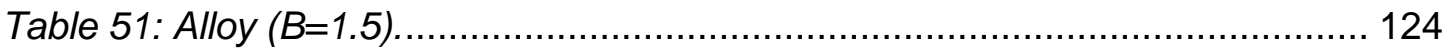

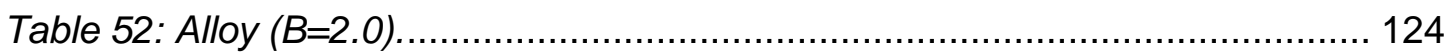

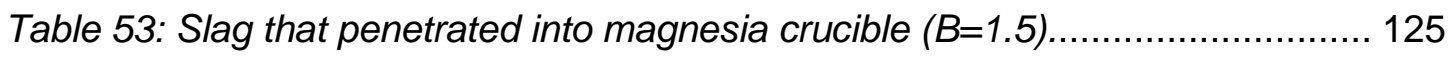

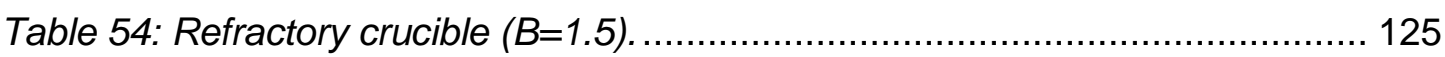

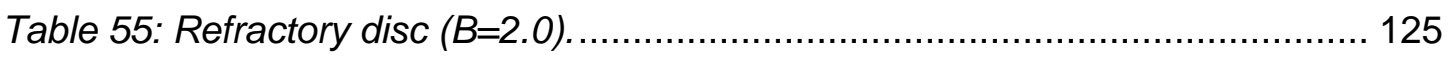

Page ix 


\section{List of Figures}

Figure 1: Research questions.

Figure 2: Low carbon ferrochrome liquidus temperature as a function of chromium content (FactSage 6.4).

Figure 3: Standard Gibbs free energies for reactions for the production of iron and chromium liquid metal and carbides (HSC Chemistry 7.1).

Figure 4: Solubility of carbon in ferrochrome silicide as a function of silicon content at $1600^{\circ} \mathrm{C}$.

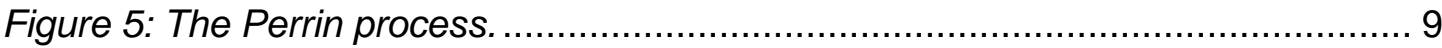

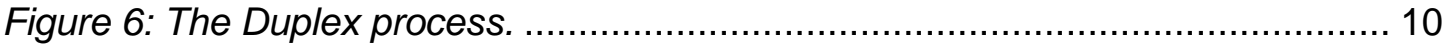

Figure 7: Solid Feed Furnace Method ............................................................. 11

Figure 8: Liquid Feed Furnace Method............................................................ 12

Figure 9: Ternary phase diagram for FeSiCr slag................................................ 18

Figure 10: Liquidus temperature variation with slag $\mathrm{SiO}_{2}$ content........................... 18

Figure 11: Inputs and outputs to the FeSiCr production process. ......................... 20

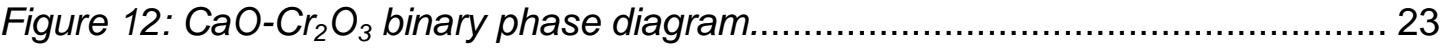

Figure 13: Inputs and outputs to the LC FeCr production process (Mixing Method). 24

Figure 14: $\mathrm{Al}_{2} \mathrm{O}_{3}-\mathrm{CaO}-\mathrm{MgO}-\mathrm{SiO}_{2}$ quaternary phase diagram (15\% $\left.\mathrm{Al}_{2} \mathrm{O}_{3}\right)$.............. 29

Figure 15: $\mathrm{Al}_{2} \mathrm{O}_{3}-\mathrm{CaO}-\mathrm{MgO}-\mathrm{SiO}_{2}$ quaternary phase diagrams (10\% and 5\% $\mathrm{Al}_{2} \mathrm{O}_{3}$ ). 30

Figure 16: Inputs and outputs to the LC FeCr production process (Furnace Method).

Figure 17: Power and total operating cost. ................................................... 40

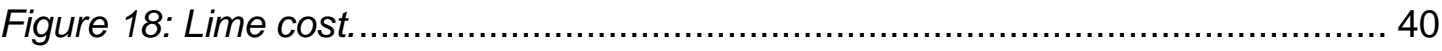

Figure 19: Steps for containing and treating of $\mathrm{Cr}(\mathrm{VI})$ waste.................................. 42

Figure 20: $\mathrm{Al}_{2} \mathrm{O}_{3}-\mathrm{CaO}-\mathrm{MgO}-\mathrm{SiO}_{2}$ quaternary phase diagrams, indicating liquidus temperatures for lime, doloma and quartz flux additions..................................... 50

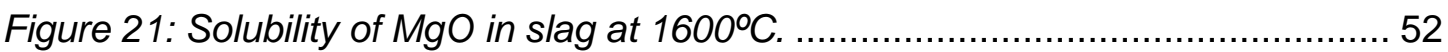

Figure 22: Slag chemistry variation for two basicity target values......................... 54

Figure 23: Slag basicity for systematic FeSiCr addition to ore-lime melt.................. 56

Figure 24: Slag basicity for systematic ore-lime addition to FeSiCr. ....................... 57

Figure 25: Metallic magnesium and silicon contents for basicities of 1.0 to 2.5....... 58

Figure 26: Standard Gibbs free energies for reactions for the dissociation of $\mathrm{MgO}$ and $\mathrm{SiO}_{2}$, as well as the reduction of $\mathrm{Mg}^{2+}$ with $\mathrm{Si}$. 59 
Figure 27: Liquidus temperature for lime slag.

Figure 28: Slag as percentage of mass for all phases for increasing slag additions for slag basicities of 0.75, 1.0, 1.5, 2.0 and 2.5 (lime slag, $\mathrm{MgO}$ refractory) at $1750^{\circ} \mathrm{C} .67$

Figure 29: Solid $\mathrm{MgO}$ as percentage of mass for all phases for increasing slag additions for slag basicities of 0.75, 1.0, 1.5, 2.0 and 2.5 (lime slag, MgO refractory) at $1750^{\circ} \mathrm{C}$

Figure 30: Slag as percentage of mass of all phases for increasing slag additions for slag basicities of 0.75, 1.0, 1.5, 2.0 and 2.5 (doloma refractory, lime slag) at $1750^{\circ} \mathrm{C}$.

Figure 31: Solid $\mathrm{MgO}+\mathrm{CaO}$ as percentage of mass for all phases for increasing slag additions for slag basicities of 0.75, 1.0, 1.5, 2.0 and 2.5 (doloma refractory, lime slag) at $1750^{\circ} \mathrm{C}$. 71

Figure 32: Liquidus temperatures for doloma slag. 75

Figure 33: Liquidus temperatures for lime and doloma slag. 75

Figure 34: Slag as percentage of mass of all phases for increasing slag additions for slag basicities of $0.75,1.0,1.5,2.0$ and 2.5 (doloma refractory, doloma slag) at $1750^{\circ} \mathrm{C}$.

Figure 35: Solid $\mathrm{MgO}+\mathrm{CaO}$ as percentage of mass for all phases for increasing slag additions for slag basicities of 0.75, 1.0, 1.5, 2.0 and 2.5 (doloma refractory, doloma slag) at $1750^{\circ} \mathrm{C}$.

Figure 36: Slag as percentage of mass of all phases for increasing slag additions for slag basicities of $0.75,1.0,1.5,2.0$ and 2.5 (doloma slag, MgO refractory) at $1750^{\circ} \mathrm{C}$.

Figure 37: Solid $\mathrm{MgO}+\mathrm{CaO}$ as percentage of mass for all phases for increasing slag additions for slag basicities of 0.75, 1.0, 1.5, 2.0 and 2.5 (doloma slag, MgO

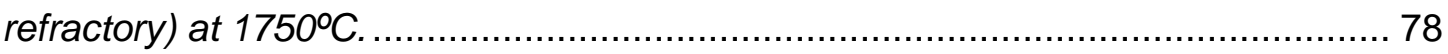

Figure 38: Liquidus temperatures for quartz slag............................................ 82

Figure 39: Liquidus temperatures for lime, doloma and quartz slag....................... 83

Figure 40: Experimental setup: Induction furnace with power supply...................... 86

Figure 41: Photo and illustration of high density sintered magnesia crucible. .......... 87

Figure 42: Illustration of experimental setup (not to scale)..................................... 89

Figure 43: Backscattered Electron Image of slag phases $(B=1.5)$......................... 90

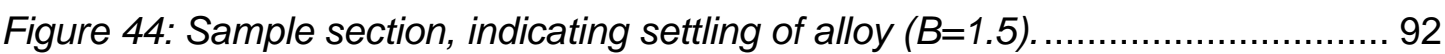

Figure 45: Backscattered Electron Image showing slag penetration in high density

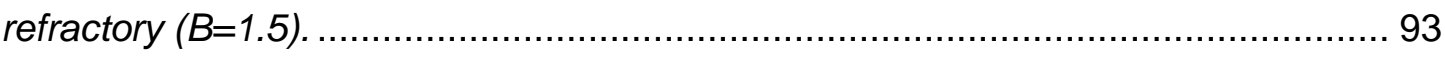

Figure 46: Backscattered Electron Image showing condition of crucible $(B=1.5)$.... 95

Figure 47: Backscattered Electron Image of slag phases $(B=2.0)$. 96

Page $x i$ 
Figure 48: Backscattered Electron Image of $\mathrm{MgO}$-rich structure $(B=2.0)$. 100

Figure 49: Backscattered Electron Image of refractory-slag interface $(B=2.0)$ 101

\section{Definition of Key Terms}

Low carbon ferrochrome (abbreviated to LC FeCr) is an alloy consisting primarily of iron and chromium. For this study, it is considered to contain less than $1 \%$ silicon, less than $0.5 \%$ carbon and at least $70 \%$ chromium.

Ferrochrome silicide (also referred to as ferrosilicon chrome, abbreviated to $\mathrm{FeSiCr}$ ) is a raw material used in the production of low carbon ferrochrome. It consists of 40 to $45 \% \mathrm{Si}, 38$ to $42 \% \mathrm{Cr}$, with the balance being iron.

Basicity: Although there are a number of ways in which slag basicity can be presented, in this document the term refers to the B3 basicity, which is calculated as:

$$
(\text { mass } \% \mathrm{CaO}+\operatorname{mass} \% \mathrm{MgO}) /\left(\operatorname{mass} \% \mathrm{SiO}_{2}\right)
$$




\section{INTRODUCTION}

Ferrochrome is one of the main raw materials used in the production of stainless steel, which typically contains between 10 and $20 \% \mathrm{Cr}$. This has an effect on a number of properties, most notably to increase corrosion and oxidation resistance (Gasik, 2013).

Although high carbon ferrochrome ( $\mathrm{HC} \mathrm{FeCr}$ ) and charge chrome are the cheapest forms of $\mathrm{FeCr}$ units, the high carbon content renders it unsuitable for the production of some steel qualities. Low carbon ferrochrome ( $\mathrm{LC} \mathrm{FeCr}$ ) is therefore used instead.

There are several methods to produce low carbon ferrochrome. However, only two of these (not considering the variations thereof) are considered to be commercially viable, namely the Mixing Method (such as the Perrin process) and the Furnace Method. These have been described extensively in earlier works (Gasik, 2013) and are briefly discussed in Section 2.3 of this document. Of the two methods, the most commonly used process is the Mixing Method (European IPPC Bureau, 2001).

At the time of writing, a project was underway for the first commercial application of the Liquid Feed Furnace Method. This variation of the Furnace Method was developed and patented by Mintek in South Africa (Smith, et al., 1996). Discussions with personnel at engineering companies also indicated that interest in this process has been increasing in recent times.

\subsection{Problem Statement}

The Mixing Method, which is the dominant process used for the production of low carbon ferrochrome, has definite shortcomings. The high temperature of the process and the fact that ladles need to be relined regularly are indicative of high energy losses and the resulting impact on the operating cost. The oxidising conditions in the ore-lime melting furnace are also ideal for the formation of $\operatorname{Cr}(\mathrm{VI})$, which is detrimental to human health. The potential that the Liquid Feed Furnace Method has to address these shortcomings has spurred interest in the process in recent times.

A quantitative and qualitative evaluation of the prevailing methods for the production of low carbon ferrochrome has not been done before. Nor has the process opportunities, risks and operating regime for the Liquid Feed Furnace Method been described in any published literature, due to the fact that it has not been implemented on commercial scale at the time of writing. 


\subsection{Research Objectives}

The questions that have been addressed in this research are diagrammatically displayed in Figure 1.

Firstly, a high level economic evaluation of the Mixing Method and Furnace Method was done to compare their economic feasibilities.

Secondly, the amount of $\mathrm{Cr}(\mathrm{VI})$ generated by the processes was determined and the effect thereof on the techno-economic feasibility of the operations considered.

Finally, different process configurations (basicity, slag composition and refractory type) were evaluated to determine what the most suitable arrangement would be. In each instance, the ability to meet the product specification and maintain the integrity of the refractory system were considered, while maintaining a process temperature that would ensure that the products have adequate superheat to be tapped and handled after smelting.

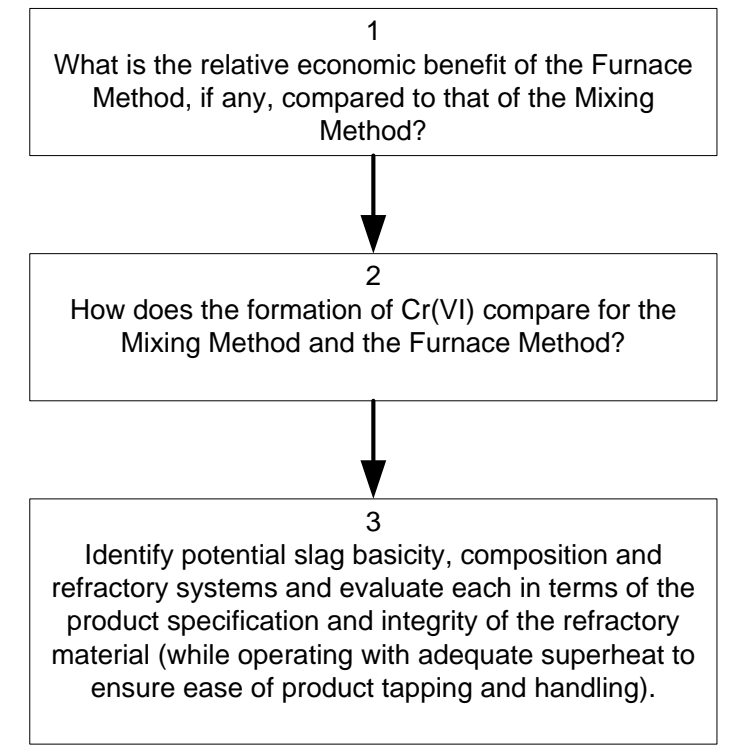

Figure 1: Research questions. 


\section{BACKGROUND}

\subsection{Specification of Low Carbon Ferrochrome}

The three most important elements to be controlled in low carbon ferrochrome are silicon, carbon and chromium.

Silicon is controlled in the process to less than $1 \%$ in the final product by controlling the FeSiCr to ore-lime ratio, as well as ensuring that there is sufficient mixing (turbulence).

Carbon dictates the process to be used as many processes cannot be used to get the desired $0.01-0.5 \%$ carbon.

Chromium is dependent on the ore quality, in particular the $\mathrm{Cr} / \mathrm{Fe}$ ratio and cannot be controlled during the smelting process. The maximum chromium content is dictated by the melting point of the alloy, as this will affect the operating temperature of the process. For an alloy with $1 \% \mathrm{Si}$, the liquidus temperature at $70 \% \mathrm{Cr}$ is just below $1750^{\circ} \mathrm{C}$ (Figure 2). Although some minor elements may affect the liquidus temperature slightly, Figure 2 does indicate that an increase in $\mathrm{Cr}$ content increases the liquidus temperature of the alloy. A higher process temperature would therefore be required to produce high $\mathrm{Cr}$ low carbon ferrochrome.

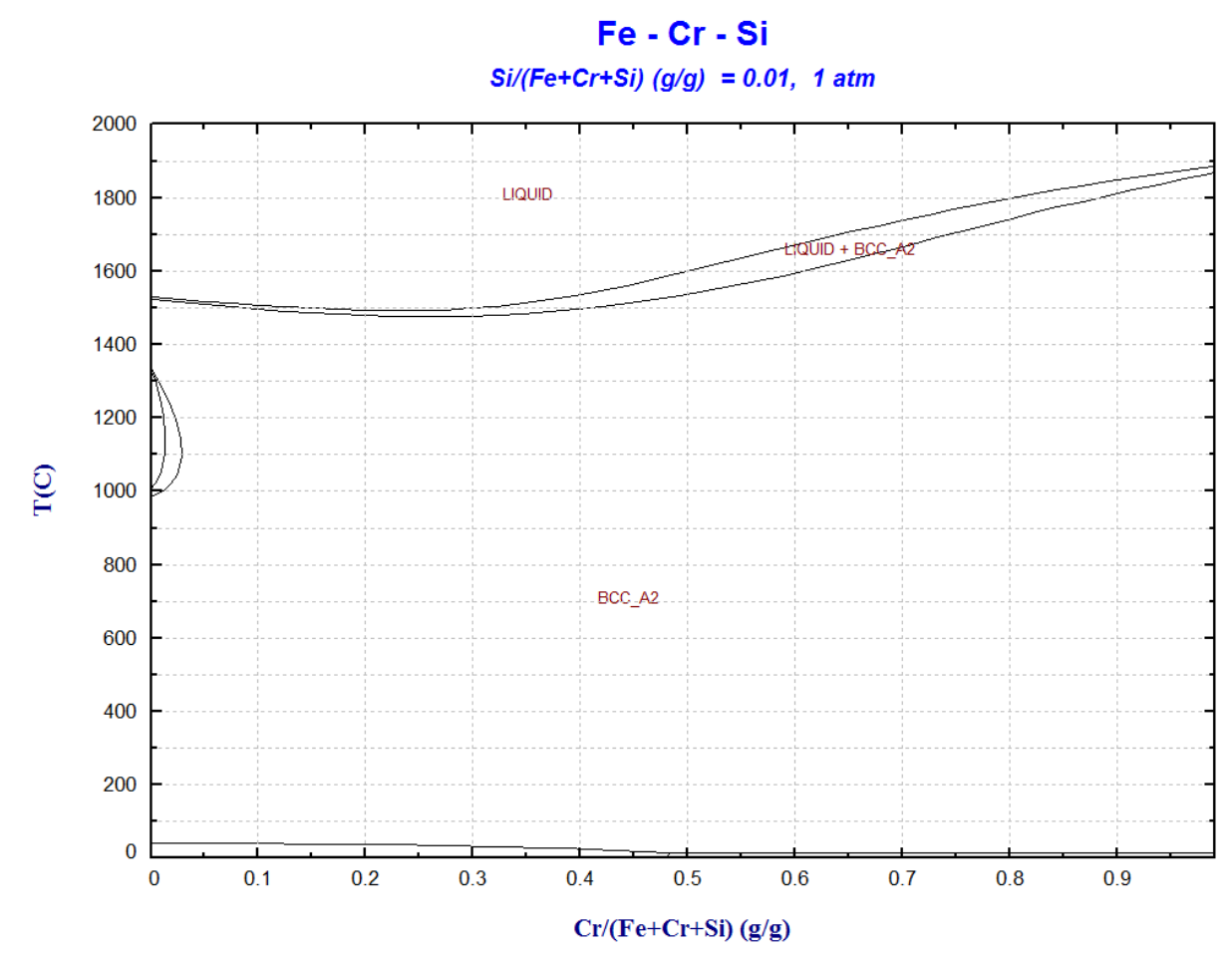

Figure 2: Low carbon ferrochrome liquidus temperature as a function of chromium content (FactSage 6.4). 
These restrictions on the elemental content limit the available process routes and production parameters.

\subsection{Process Options}

A number of processes are available for producing low carbon ferrochrome. However, not all process options are financially and practically feasible. In their paper, Bhonde et al (2007) describe several conventional and non-conventional techniques for the production of low carbon ferrochrome.

Most of the non-conventional techniques involve reaction of chromite or high carbon ferrochrome in the solid state. Although these techniques allow for processing at lower temperatures and do not produce significant amounts of slag and fume, the processes are very slow and oxides are often retained in the product. These processes are therefore not commercially feasible at this stage.

The only options that are currently feasible are the refining of high carbon ferrochrome and metallothermic reduction.

\subsubsection{Carbothermic Reduction of Chromite Ore}

In the production of ferrochrome through carbothermic reduction, the metallic chromium that is formed will tend to further react with available carbon to form $\mathrm{Cr}_{3} \mathrm{C}_{2}$, $\mathrm{Cr}_{7} \mathrm{C}_{3}$ and $\mathrm{Cr}_{23} \mathrm{C}_{6}$ (Robiette, 1973: 155). Similarly, the metallic iron will react with carbon to form $\mathrm{Fe}_{3} \mathrm{C}$ and $\mathrm{Fe}_{2} \mathrm{C}$. These carbides have theoretical carbon contents of between 5.5 to $13.3 \%$, and their presence increases the alloy total carbon content to more than the specified limit. The simplified reactions that take place in the process are:

$$
\begin{array}{lr}
\mathrm{Cr}_{2} \mathrm{O}_{3(l)}+3 \mathrm{C}=2 \mathrm{Cr}_{(l)}+3 \mathrm{CO}_{(\mathrm{g})} & \ldots \text { Eq. } 1 \\
\mathrm{Cr}_{2} \mathrm{O}_{3(l)}+13 / 3 \mathrm{C}=2 / 3 \mathrm{Cr}_{3} \mathrm{C}_{2}+3 \mathrm{CO}_{(\mathrm{g})} & \ldots \text { Eq. } 2 \\
\mathrm{Cr}_{2} \mathrm{O}_{3(l)}+7 / 2 \mathrm{C}=1 / 2 \mathrm{Cr}_{4} \mathrm{C}+3 \mathrm{CO}_{(\mathrm{g})} & \ldots \text { Eq. 3 } \\
\mathrm{Cr}_{2} \mathrm{O}_{3(l)}+27 / 7 \mathrm{C}=2 / 7 \mathrm{Cr}_{7} \mathrm{C}_{3}+3 \mathrm{CO}_{(\mathrm{g})} & \ldots \text { Eq. } 4 \\
\mathrm{Cr}_{2} \mathrm{O}_{3(l)}+81 / 23 \mathrm{C}=2 / 23 \mathrm{Cr}_{23} \mathrm{C}_{6}+3 \mathrm{CO}_{(\mathrm{g})} & \ldots \text { Eq. } 5 \\
\mathrm{Fe}_{2} \mathrm{O}_{3(l)}+3 \mathrm{C}=2 \mathrm{Fe}_{(l)}+3 \mathrm{CO}_{(\mathrm{g})} & \ldots \text { Eq. } 6 \\
\mathrm{Fe}_{2} \mathrm{O}_{3(l)}+11 / 3 \mathrm{C}=2 / 3 \mathrm{Fe}_{3} \mathrm{C}+3 \mathrm{CO}_{(\mathrm{g})} & \ldots \text { Eq. } 7 \\
\mathrm{Fe}_{2} \mathrm{O}_{3(l)}+4 \mathrm{C}=\mathrm{Fe}_{2} \mathrm{C}+3 \mathrm{CO}_{(\mathrm{g})} & \ldots \text { Eq. 8 }
\end{array}
$$

The standard Gibbs free energies for the formation of these carbides (by reaction between $\mathrm{Cr}_{2} \mathrm{O}_{3}$ dissolved in the slag and solid, unreacted carbon) were investigated. The results showed that the Gibbs free energy values for the formation of $\mathrm{Fe}_{3} \mathrm{C}$ (Eq. 7) is lower than that for the formation of metallic iron (Eq. 6) for the entire temperature range evaluated (1500 to $2000^{\circ} \mathrm{C}$ ) (Figure 3). Thermodynamics therefore favour the formation of $\mathrm{Fe}_{3} \mathrm{C}$. Similarly, the reaction Gibbs free energy for 
the formation of $\mathrm{Cr}_{3} \mathrm{C}_{2}$ (Eq. 2) is lower than that of metallic chromium (Eq. 1) for most of the temperature range (up to approximately $1920^{\circ} \mathrm{C}$ ). $\mathrm{Cr}_{7} \mathrm{C}_{3}$ (Eq. 4) and $\mathrm{Cr}_{4} \mathrm{C}$ (Eq. 3) may also form at temperatures below 1650 and $1550^{\circ} \mathrm{C}$, respectively. The formation of these carbides from the magnesia-chrome spinel (instead of the dissolved $\mathrm{Cr}_{2} \mathrm{O}_{3}$ ) shows exactly the same trend. Several carbides therefore form preferentially to the metallic chromium and iron, irrespective of whether chrome oxide or magnesia-chrome spinel is reduced.

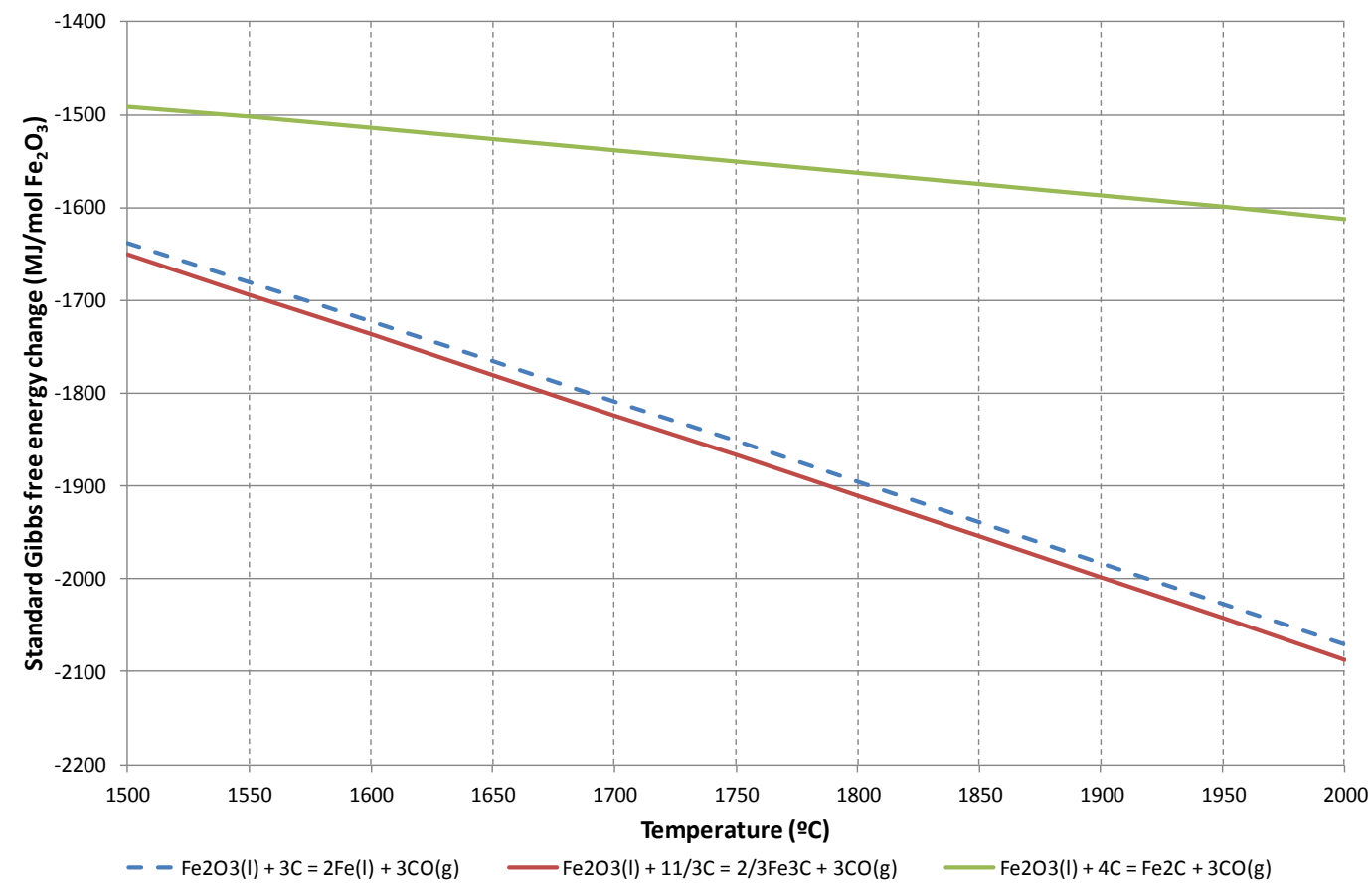

(a) $\mathrm{Fe}_{2} \mathrm{O}_{3}$ reduction

\section{Page 5}




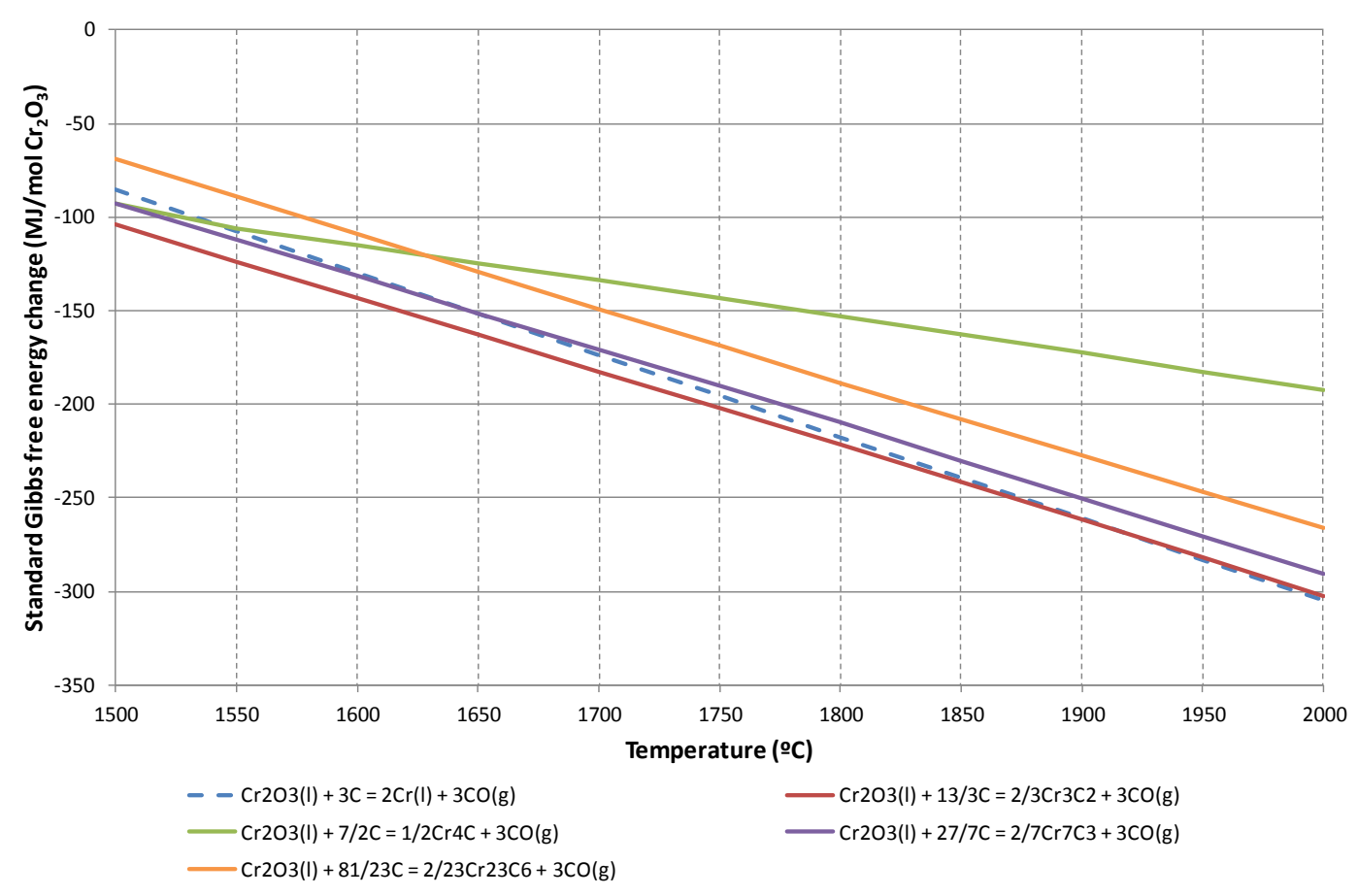

(b) $\mathrm{Cr}_{2} \mathrm{O}_{3}$ reduction

Figure 3: Standard Gibbs free energies for reactions for the production of iron and chromium liquid metal and carbides (HSC Chemistry 7.1).

As a result, low carbon ferrochrome cannot be produced directly through carbothermic reduction of chromite ore. The products from carbothermic reduction are therefore high carbon ferrochrome $(\mathrm{HC} \mathrm{FeCr})$ or charge chrome, depending on the chromium to iron ratio in the ore.

Low carbon ferrochrome can be produced from high carbon ferrochrome or charge chrome (although the chromium content in the latter may be somewhat low). This is done by adding chromite ore or blowing oxygen through high carbon ferrochrome (Bhonde, et al., 2007). The high temperature $(2375 \mathrm{~K})$ required to decrease the carbon content to within the specification for $\mathrm{LC} \mathrm{FeCr}$, as well as the chromium losses, respectively make these processes unattractive (Bhonde, et al., 2007). These methods for decreasing the carbon content of high carbon ferrochrome are therefore generally only used for the production of medium carbon ferrochrome.

That leaves metallothermic production routes as the primary method for producing low carbon ferrochrome.

\subsubsection{Metallothermic Reduction of Chromite Ore}

In order to be a technically suitable reductant, the reduction reaction for chromite with a specific metal, should have a negative Gibbs free energy. The only materials that fall within this criteria and are produced in bulk are aluminium, magnesium, manganese and silicon. The stoichiometric consumption for each is shown in Table 1 , along with their cost per tonne of chromium metal produced. In practice, the 
consumptions may differ slightly, depending on the targeted chromium recovery. However, the values in Table 1 give an indication of the relative reductant costs for producing one tonne of chromium.

Table 1: Metal consumption for Cr production.

\begin{tabular}{|l|c|c|}
\hline Metal & $\begin{array}{c}\text { Consumption } \\
\text { (t/t Cr) }\end{array}$ & $\begin{array}{c}\text { Cost per tonne } \mathbf{C r}^{*} \\
\text { (US\$) }\end{array}$ \\
\hline Aluminium & 0.519 & 891 \\
\hline Magnesium & 0.701 & 1578 \\
\hline Manganese & 1.585 & 2877 \\
\hline Silicon** $^{*}$ & 0.405 & $704-1069$ \\
\hline
\end{tabular}

* Prices from www.metalbulletin.com (15 August 2015).

** Calculated using 75\% FeSi for the lower value and Si metal for the higher value.

From this data, it is evident that aluminium and silicon are economically the most viable options for use as metallothermic reductants. Of the two, only silicon (in the form of ferrochrome silicide) can readily be produced on a smaller scale on site. This is likely the reason for the prevalence in its use. The amount of information available for silicothermic reduction in the ferroalloy industry is therefore significantly more than that of aluminothermic reduction.

It has been shown that the solubility of carbon in molten ferrochrome silicide decreases with an increase in the silicon content (Kossyrev \& Olsen, 1995) (Figure 4). 


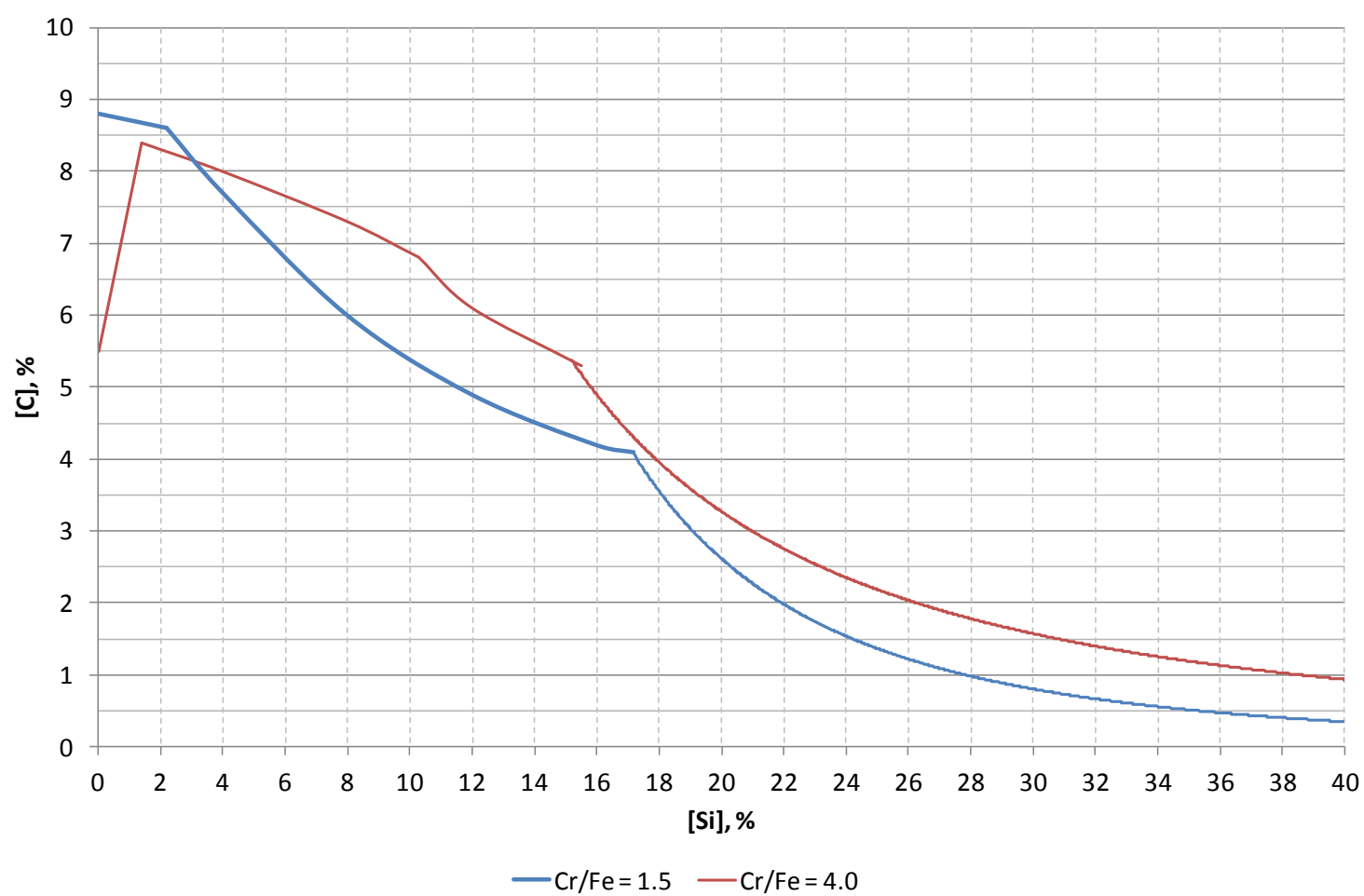

Figure 4: Solubility of carbon in ferrochrome silicide as a function of silicon content at $1600^{\circ} \mathrm{C}$.

(adapted from Kossyrev and Olsen, 1995).

When producing ferrochrome silicide, carbon would therefore not be dissolved in the alloy product to a considerable extent. Ferrochrome silicide is therefore ideally suited to be a reducing agent in the production of low carbon ferrochrome as it does not introduce a significant amount of additional carbon to the product.

\subsection{Existing Production Routes}

Silicothermic reduction of chromite ore involves the mixing of ferrochrome silicide with a mixture of ore and burnt lime. The latter is added to optimise the slag liquidus temperature and promote chromium recovery (Pretorius \& Muan, 1992). $\mathrm{The} \mathrm{Cr}_{2} \mathrm{O}_{3}$ in the liquid slag is reduced by silicon, as shown in the simplified reaction:

$$
2 \mathrm{Cr}_{2} \mathrm{O}_{3}+3 \mathrm{Si}=4 \mathrm{Cr}+3 \mathrm{SiO}_{2}
$$

The two prevalent processes for the production of low carbon ferrochrome have been described in detail in earlier work (Gasik, 2013). A short overview of the processes is discussed in this section.

\subsubsection{Process 1: Mixing Method}

Processes that involve mixing of materials (cocktailing) in ladles will be referred to as the Mixing Method, in agreement with the work by Gasik (2013).

\section{Page 8}


The prevalence of the use of the Mixing Method is indicative of the advantages that it offers. However, it does also have some distinct disadvantages, which include high energy losses due to the exothermic reactions during the ladle cocktailing, high process temperature that results in high refractory wear, as well as material losses due to spillage. The ore-lime melt is also produced under oxidising conditions. This results in the formation of up to $1 \% \mathrm{CrO}_{3}$, in which chromium is present as the harmful Cr(VI) (Gasik, 2013).

The Mixing Method is a three-step process, which can be summarised as follows:

FeSiCr is produced in a semi-open submerged arc furnace. Simultaneously, an orelime melt is produced in an open arc furnace. The products from both of these steps are then mixed (cocktailed) in ladles to produce LC FeCr.

\subsubsection{Mixing Method: Perrin Process}

The Perrin process was developed in the 1930's for deoxidation of steel by cocktailing it with slag (Perrin, 1937). Perrin also realised its potential for the manufacturing of ferroalloys with a low carbon specification, specifically ferrochrome.

The ferrochrome silicide produced in the semi-closed submerged arc furnace contains between 35 and $43 \% \mathrm{Si}, 38$ to $40 \% \mathrm{Cr}$ and 0.03 to $0.05 \% \mathrm{C}$, while the slag from the open arc smelter contains 24 to $26 \% \mathrm{Cr}_{2} \mathrm{O}_{3}$ and 40 to $46 \% \mathrm{CaO}$ (Ghose, et al., 1983). The basic concept of the process is shown in Figure 5.

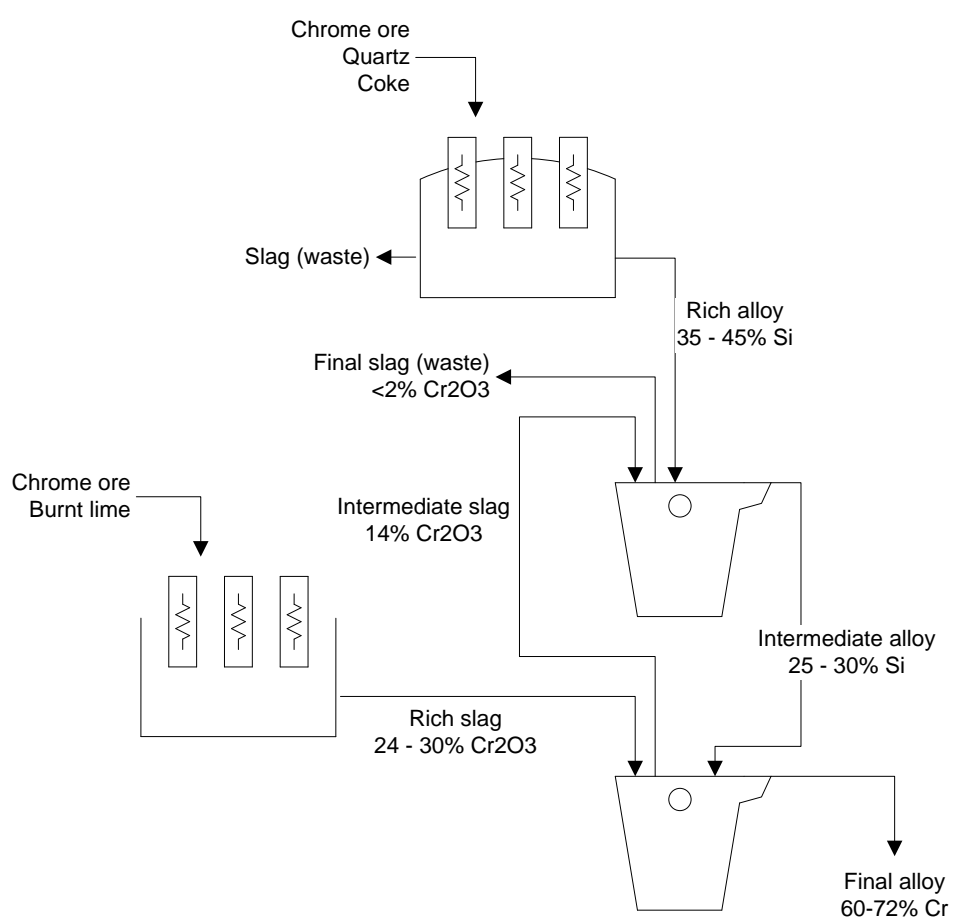

Figure 5: The Perrin process.

(Adapted from Robietta (1973) and Ghose et al, (1983)) 
The FeSiCr and slag are tapped into separate ladles. The alloy is then decanted into the slag, allowing the silicon from the alloy to reduce the $\mathrm{Cr}_{2} \mathrm{O}_{3}$ and $\mathrm{Fe}_{2} \mathrm{O}_{3}$ in the slag. The entire contents of the ladle are then poured back into the other ladle. This can be repeated several times to ensure that the reaction product compositions are within the desired ranges.

For optimal operation, the $\mathrm{Cr}_{2} \mathrm{O}_{3}$-rich slag reacts with the intermediate alloy to produce the final product, while the intermediate slag reacts with the rich alloy in a slag cleaning step. The final slag has a $\mathrm{Cr}_{2} \mathrm{O}_{3}$ content of approximately $2 \%$ (Ghose, et al., 1983).

\subsubsection{Mixing Method: Duplex Process}

The Duplex process is a variation of the Perrin process, developed with the aim of addressing some of the drawbacks from the Perrin process. The process is illustrated in Figure 6.

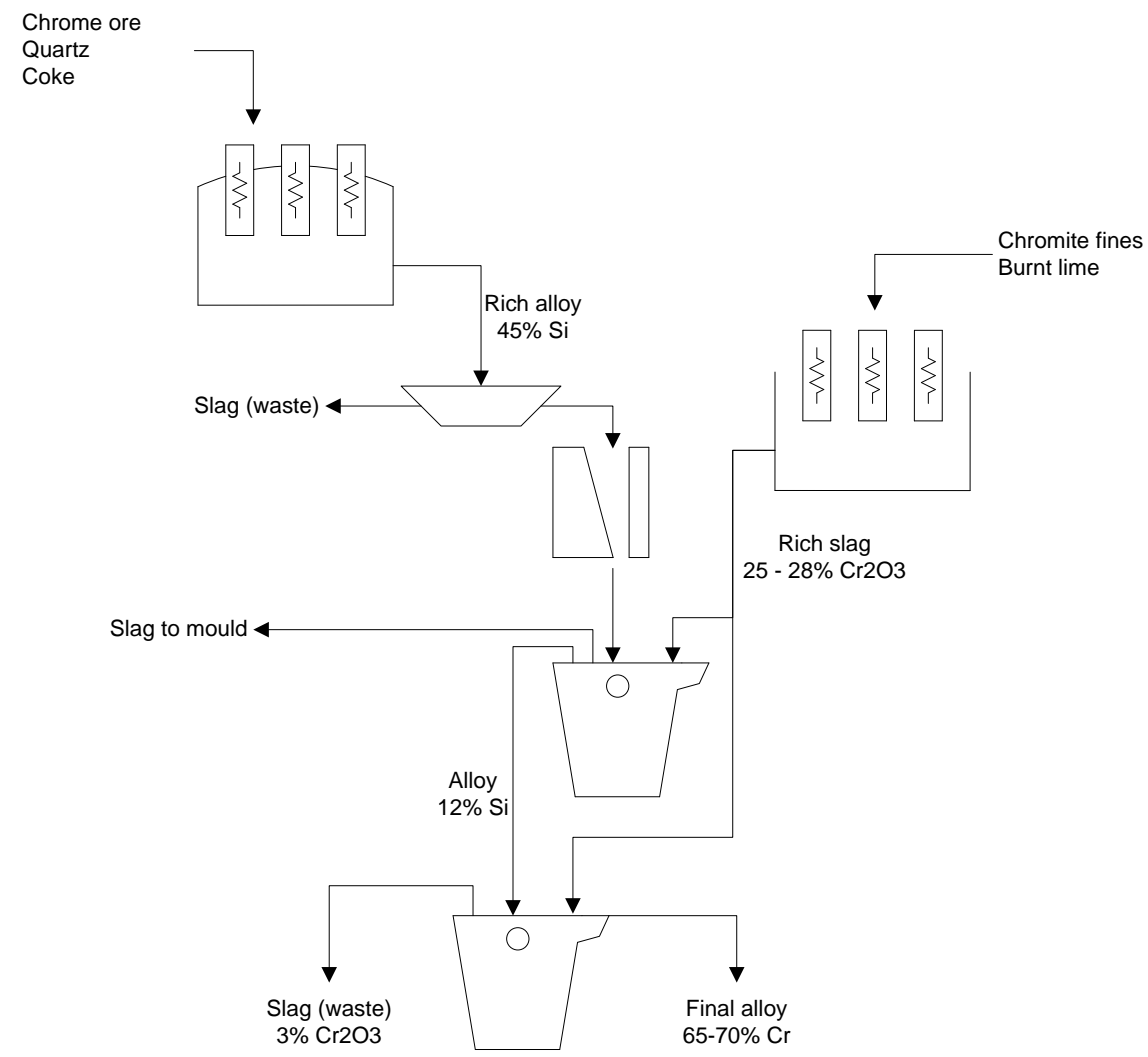

Figure 6: The Duplex process.

(Adapted from Robietta (1973) and Ghose et al, (1983))

Ferrochrome silicide and an ore-lime melt (slag) are produced, similar to the Perrin process. However, the FeSiCr is cast and crushed before being introduced to the process. The Si-rich alloy is fed into a $\mathrm{Cr}_{2} \mathrm{O}_{3}$-rich slag at a controlled rate in order to produce an intermediate alloy, containing 12 to $15 \%$ silicon. The intermediate alloy 
reacts with $\mathrm{Cr}_{2} \mathrm{O}_{3}$-rich slag in order to decrease the silicon content to $<1 \%$. The final slag contains approximately $3 \% \mathrm{Cr}_{2} \mathrm{O}_{3}$ which, although it is higher than that of the Perrin process, is still low enough to be offset against the benefits that are gained.

As with the Perrin process, the exothermic energy from the cocktailing operation is lost. Cooling and crushing of the FeSiCr before crushing allows the two furnaces to be de-linked. The fact that the FeSiCr enters the cocktailing process in the solid state decreases the maximum temperature of the cocktailing process, thereby improving the life of the ladle refractories. The chromium recovery is slightly lower though, likely due to the lower temperature.

\subsubsection{Process 2: Furnace Method}

The Furnace Method is an alternative to the Mixing Method and has the benefit of utilising the exothermic energy from the silicothermic reduction, which is normally lost to the atmosphere in the Mixing Method.

\subsubsection{Solid Feed Furnace Method (SFFM)}

The Solid Feed Furnace Method is shown in Figure 7.

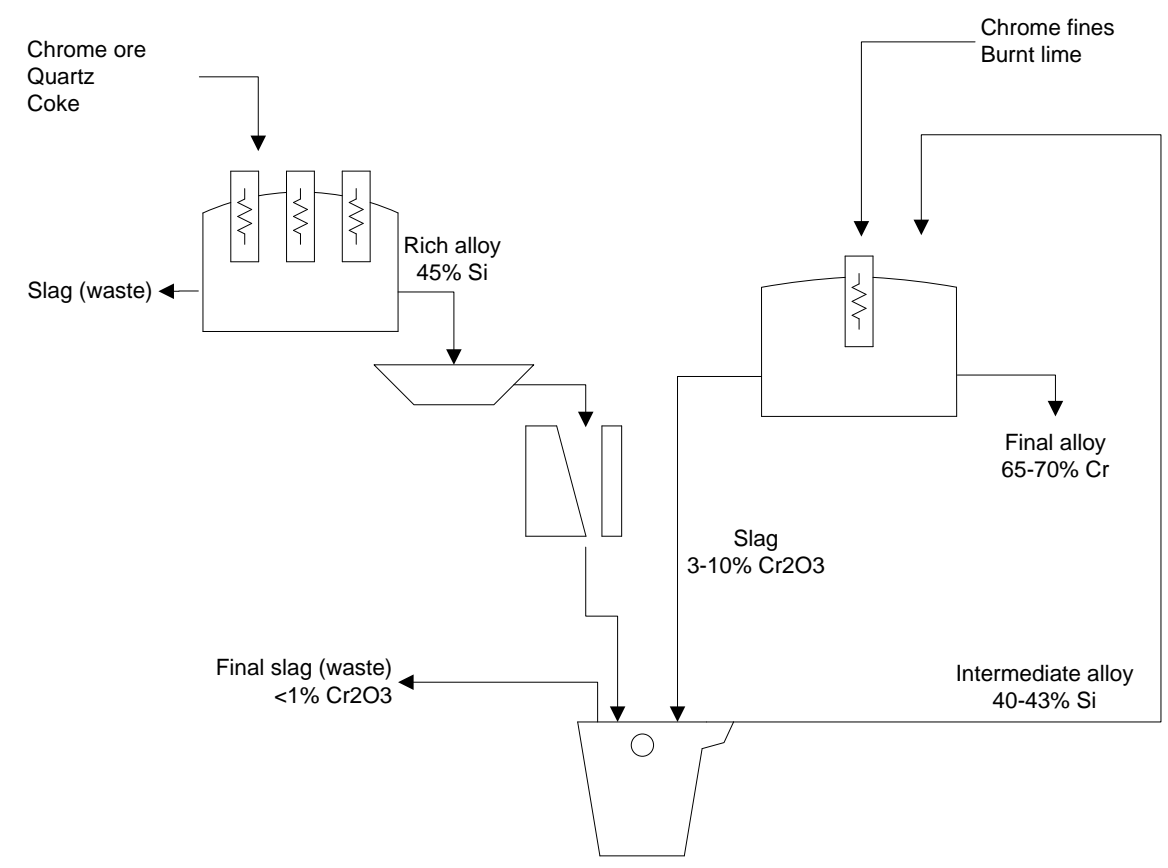

Figure 7: Solid Feed Furnace Method.

This process involves the addition of ferrochrome silicide into a closed ore-lime melt furnace, thereby eliminating the cocktailing step. The FeSiCr is cast, crushed and mixed with the ore and lime before feeding to the LC FeCr furnace. The benefits of this are that the amount of handling of molten material is decreased. 


\subsubsection{Liquid Feed Furnace Method (LFFM)}

A variation of the Furnace Method allows for feeding of liquid ferrochrome silicide instead of cast and crushed alloy (Figure 8). This has the added benefit of utilising not only the exothermic energy, but also the latent and sensible heat of the ferrochrome silicide, which would normally have been lost to the atmosphere.

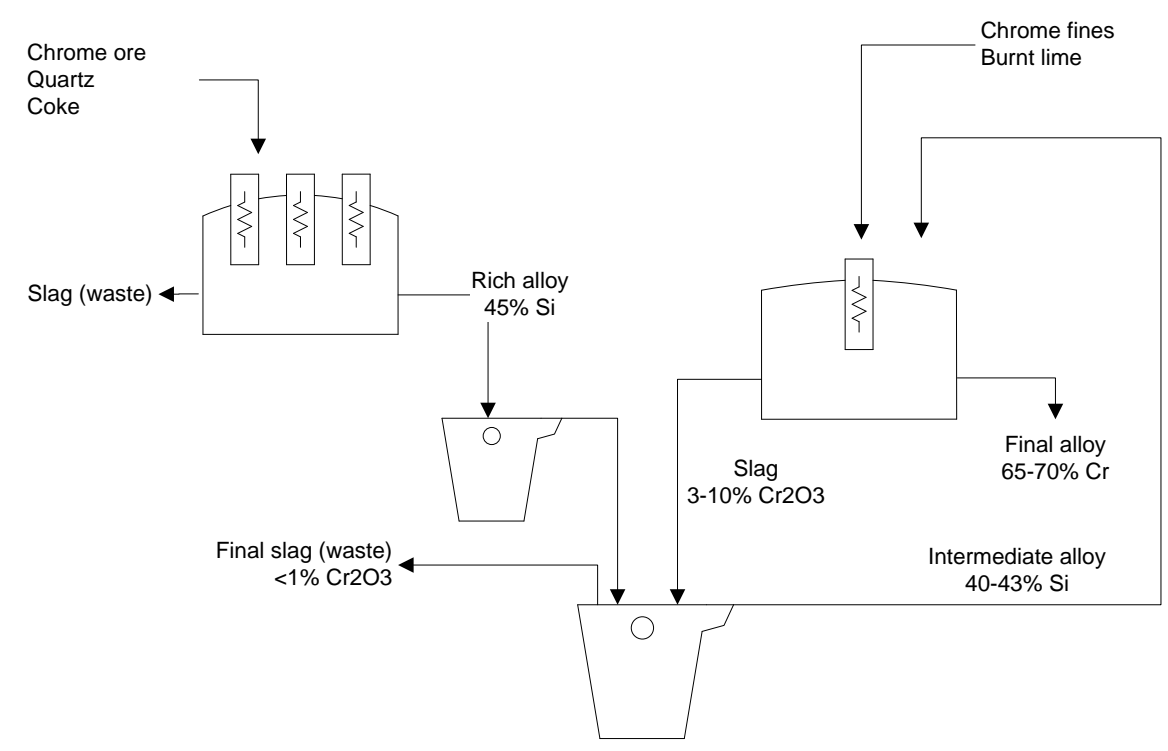

Figure 8: Liquid Feed Furnace Method.

FeSiCr, containing 42 to $45 \% \mathrm{Si}$ is produced in a submerged arc furnace. The Si-rich alloy is poured into the ladles containing the slag from the ore-lime melt furnace, which contains $3-10 \% \mathrm{Cr}_{2} \mathrm{O}_{3}$. The purpose of this step is to decrease the amount of $\mathrm{Cr}_{2} \mathrm{O}_{3}$ that is discarded. The liquid $\mathrm{FeSiCr}(40-43 \% \mathrm{Si})$ is fed directly into a closed, open-bath electric furnace to produce low carbon ferrochrome and a low grade slag.

As the overall process is endothermic, the process is reliant on electrical energy, which results in improved control of the energy balance. The process is contained in a closed furnace, thereby limiting the exposure of personnel to the molten alloy and slag. Dust is therefore also contained to a greater extent.

\subsection{Evaluation of Practices}

The focus of this section is to provide more detail of the operating methodology for the Liquid Feed Furnace Method and the Mixing Method (Perrin Process). The equipment is described briefly, as well as the heat progression, which provides some insight into the practical aspects of the process operation.

\subsubsection{Equipment Description}

The production of $\mathrm{FeSiCr}$ is similar for both the Mixing and Furnace Methods. However, the LC FeCr furnace used in the LFFM differs somewhat from the ore-lime melt furnace used for the Mixing Method. As the LFFM is the most recently 
developed process, it is the subject of the discussion and as compared to the Mixing Method. The most significant differences are:

A single electrode (direct current) is used for the LFFM instead of the three electrode alternating current setup of the Mixing Method. This is due to the fact that the LFFM process is not oxidising as with the ore-lime melt furnace, which increases the risk of carbon contamination from the electrode(s). Using a single electrode decreases the extent of contamination.

A stationary furnace is used instead of a tilting furnace. The slag has a lower liquidus temperature than the ore-lime melt from the Mixing Method due to the $\mathrm{SiO}_{2}$ that the silicothermic reduction introduces to the process. Tapping can therefore be done through tap holes.

The furnace has a closed roof for minimising heat losses, limiting the escape of particulates and $\mathrm{Cr}(\mathrm{VI})$ formation. This is possible due to the fact that the furnace is stationary (not tiltable).

The furnace is water-cooled to protect the sidewall refractories through the establishment of a freeze lining. The ore-lime melt in the Mixing Method has a very high liquidus temperature and therefore readily solidifies on the periphery of the furnace to form a freeze lining. The sidewall is therefore considered to be selfhealing. A freeze lining in the Liquid Feed Furnace Method furnace would provide similar protection of the furnace sidewall.

\subsubsection{Process Description}

Although the processes have been described in some detail in Section 2.3.2, this section addresses the process flow from a practical point of view. Again, the $\mathrm{FeSiCr}$ furnace is not discussed, as it is common for both processes.

As is the case for the Mixing Method, the LFFM is a semi-batch process. The compositions of the bulk alloy and slag in a continuous process remain relatively constant over time, with only slight variation from the target value (barring any control or equipment malfunctions or significant raw material variations). Although the furnaces are operated on a continuous basis, the slag and alloy undergoes distinct compositional changes with time, therefore the classification as semi-batch processes.

In the case of the Mixing Method, the ore-lime melt furnace is operated at a fixed power input and the feed is added at a constant rate, as a ratio of the power input. The feed to power ratio may be altered from time to time based on raw material variations, but generally remains unchanged. Once the required feed material and the corresponding electrical energy have been added, the contents are tapped from the tilting furnace into a ladle. Overhead cranes are then used to cocktail the ore-lime melt with FeSiCr, which was tapped into a separate ladle. This is done up to six times to ensure that the required silicon specification in the alloy is achieved.

As exothermic reactions take place in the LFFM low carbon FeCr furnace, control is somewhat more complex. Without the benefit of a self-healing sidewall, which is 
prevalent in the high liquidus temperature ore-lime melt, the control of the energy balance becomes crucial for maintaining the integrity of the refractory lining. The feed ratio and power input are therefore adjusted throughout the heat to maintain a constant energy balance and process temperature.

A fraction of the ore-lime mixture is fed into the furnace at the start of the heat. Once $\mathrm{FeSiCr}$ is available, the contents of the ladle are fed by means of a hot metal launder into the furnace and starts reacting with the ore-lime mixture. The remainder of the ore-lime mixture is introduced after the FeSiCr. The exothermic energy from the silicothermic reduction reactions is therefore utilised for the melting of the solid ore and lime. Although additional energy is available from the exothermic reactions, the furnace power will likely not be decreased. Instead, the split between the ore-lime mixture fed before and after FeSiCr addition will be optimised, and the feed rate selected to ensure that the maximum amount of power can be utilised for the process, while maintaining a constant process temperature.

In practice, the two furnaces (FeSiCr and LC FeCr furnaces) used in the LFFM will be tapped simultaneously. As soon as the FeSiCr has been deslagged and weighed, it will be hot fed to the LC FeCr furnace. The FeSiCr will be fed in a short period of time (typically within 5 minutes) to limit the amount of solidification losses.

The only period, where the power input is decreased is during the holding period towards the end of the heat (prior to tapping). The purpose of this period is to allow the furnace to reach near equilibrium conditions. No material is therefore fed during this period and the power input is therefore decreased to prevent the furnace from overheating. The duration of the holding period will depend on the reaction kinetics and may be changed to optimise the process.

Where the Mixing Method relies on the momentum imparted by the cocktailing process to ensure good contact between the reactants, the LFFM relies on the momentum from the electrical arc, as well as the large slag-metal interface in the furnace (relative to that of a ladle). 


\section{TECHNO-ECONOMIC EVALUATION}

Silicothermic reduction is the only technically and commercially feasible route for the production of low carbon ferrochrome, as shown in Section 2. In this section, the economic feasibility of the Mixing and Furnace Methods are compared. The effect that certain technical aspects have on the feasibility of these process routes is also addressed.

The purpose of this section is not to provide anyone interested in expanding their facilities with a clear cut answer as to which process route to follow. This would be very dependent on what is available on the plant, the production throughput, the region in which the plant is built and the source of the major pieces of equipment, amongst others. Addressing the entire spectrum of variations is not practical. Instead, the focus is to provide insight into the elements that affect the feasibility of each process route.

\subsection{Capital Expenditure}

The focus of this section is not to attach a monetary value to the different options, but rather to put the orders of magnitude into perspective.

The capital expenditure was compared by looking at the type of equipment that would be required for the production of low carbon ferrochrome. The size of the equipment was not considered, as it was assumed that they would scale up in the same proportions. Using this approach, it appears that the two options compare fairly well. The major process equipment that is required for both process options are listed in Table 2.

Table 2: Comparison between capital expense items for the Mixing and Furnace Methods.

\begin{tabular}{|l|l|l|}
\hline & $\begin{array}{l}\text { Mixing Method } \\
\text { (Perrin and Duplex) }\end{array}$ & $\begin{array}{l}\text { Furnace Method } \\
\text { (SFFM and LFFM) }\end{array}$ \\
\hline FeSiCr furnace & $\begin{array}{l}\text { FeSiCr furnace, along with its batching, feeding, off-gas and } \\
\text { product handling facilities are common for both methods. }\end{array}$ \\
\hline LC FeCr furnace & $\begin{array}{l}\text { Ore-lime melt furnace. Open } \\
\text { arc operation, open furnace. } \\
\text { No roof required for furnace. }\end{array}$ & $\begin{array}{l}\text { LC FeCr furnace. Open arc } \\
\text { operation, closed furnace. Cost } \\
\text { of roof offset by smaller furnace } \\
\text { size (lower energy requirement). }\end{array}$ \\
\hline Mixing / Cocktailing & Cranes and ladles required in both instances. \\
\hline
\end{tabular}

Although it was not quantified, the comparison between the two methods indicated that there would be little difference in their capital cost. 


\subsection{Operating Expenditure}

Due to the similarity in the types of equipment used for the two process routes, the capital cost could be evaluated qualitatively. The operating cost, on the other hand, needs a more detailed analysis. In this section an attempt is made to quantify the difference between the two process routes. The assumptions that were made are described to explain to the reader how the values were obtained.

The operating cost per tonne of product produced is subject to economies of scale, as the energy consumption (thermal efficiency), labour requirements and overheads do not increase in relation to the increase in production rate. For the purpose of this paper, a fictional facility producing $40 \mathrm{ktpa}$ of low carbon ferrochrome was considered. This production rate was chosen, as a number of plants produce similar quantities. These include Samancor $\mathrm{Cr}$ Middelburg Ferrochrome (40 000 tpa) (Basson, et al., 2007), Zimalloys (40 150 tpa) (Chirasha, 2011) and Eti Elektrometalurji (36 000tpa) (Eti Elektrometalurji A.S., 2014).

As this study is not focussed on a specific country or region, the price ranges can vary significantly. This variation has been addressed as far as possible.

\subsubsection{Mass and Energy Balances}

Before starting with the evaluation of the operating cost, mass and energy balances of the different processes needed to be performed. The raw materials and electricity costs are likely to be major contributors to the operating cost. Quantifying the consumptions thereof is therefore very important.

As the purpose of the balance was to determine indicative consumptions, only high level balances were performed. Only basic components were considered in the mass and energy balances. The effects of minor elements were not considered, as they would not affect the raw material and energy consumptions significantly, especially compared to the variation that would result from using raw materials with a different composition to that used in the balances. Gibbs minimisation was not employed when conducting the balances. Instead, assumptions were made based on data from an existing operation. Typical raw material compositions and slag basicity targets from the reference plant, which uses the Perrin process, were used for the mass and energy balance. The analyses of the raw materials are shown in the respective mass and energy balances. The target FeSiCr analysis is shown in Table 3. Lime was considered to be pure $\mathrm{CaO}$. 
Table 3: FeSiCr Analysis used in Modelling.

\begin{tabular}{|l|c|c|}
\hline FeSiCr & Unit & Value \\
\hline $\mathrm{Cr}$ & wt $\%$ & 40.00 \\
\hline $\mathrm{Fe}$ & wt $\%$ & 18.00 \\
\hline $\mathrm{Si}$ & wt $\%$ & 42.00 \\
\hline
\end{tabular}

\subsubsection{Ferrochrome Silicide}

FeSiCr is common for all of the processes. It was therefore modelled in isolation, and the results included in the total consumption for each of the processes.

The process shares many traits with silicon metal production due to the high silicon content in the alloy. In the upper, cooler part of the furnace, the following reactions occur (Tangstad, et al., 2010):

$$
\begin{aligned}
& \mathrm{SiO}_{(g)}+2 \mathrm{C}=\mathrm{SiC}+\mathrm{CO}_{(g)} \\
& 2 \mathrm{SiO}_{(g)}=\mathrm{Si}+\mathrm{SiO}_{2(g)}
\end{aligned}
$$

While in the lower, hotter part of the furnace, the following reactions occur:

$$
\begin{aligned}
& \mathrm{SiO}_{2}+2 \mathrm{SiC}=3 \mathrm{Si}_{(g)}+2 \mathrm{CO}_{(g)} \\
& \mathrm{Si}+\mathrm{SiO}_{2}=2 \mathrm{SiO}_{(g)}
\end{aligned}
$$

From these equations it can be seen that $\mathrm{SiO}$ gas plays an important role in the production of metallic silicon. However, if insufficient carbon is available in the upper region of the furnace, the $\mathrm{SiO}$ gas will continue to rise and react with the ingress air to produce microsilica $\left(\mathrm{SiO}_{2}\right)$. Too much carbon is also undesirable, as it results in excess formation of $\mathrm{SiC}$, which will tend to build up in the furnace if insufficient $\mathrm{SiO}_{2}$ is available to react with. In practice, it is crucial to ensure that the SiO gas has sufficient contact time with the carbon that is available in the process. This is done by continually pushing fresh raw materials to areas where $\mathrm{SiO}$ gas is being released to the furnace freeboard area, a practice called stoking.

Modelling of the FeSiCr production process is therefore complex, as the efficiency of the process depends largely on the amount of SiO gas losses, which in turn depends on the diligence of the operating team.

The primary components in the slag are $\mathrm{Al}_{2} \mathrm{O}_{3}, \mathrm{MgO}$ and $\mathrm{SiO}_{2}$. Neither $\mathrm{Al}_{2} \mathrm{O}_{3}$ nor $\mathrm{MgO}$ are expected to react to a significant extent. The amounts in the slag are a direct result of the amounts in the raw materials. The only variable component in the slag is therefore $\mathrm{SiO}_{2}$. The effect that a variation in the $\mathrm{SiO}_{2}$ content has on the liquidus temperature was derived from Figure 9 and plotted in Figure 10. The primary source of $\mathrm{MgO}$ and $\mathrm{Al}_{2} \mathrm{O}_{3}$ is the chromite ore $\left(\mathrm{MgO} / \mathrm{Al}_{2} \mathrm{O}_{3}\right.$ mass ratio of 1.70). The 
ratio of $\mathrm{MgO}$ and $\mathrm{Al}_{2} \mathrm{O}_{3}$ therefore remains relatively constant for the entire range of $\mathrm{SiO}_{2}$ compositions in the slag in Figure 9.

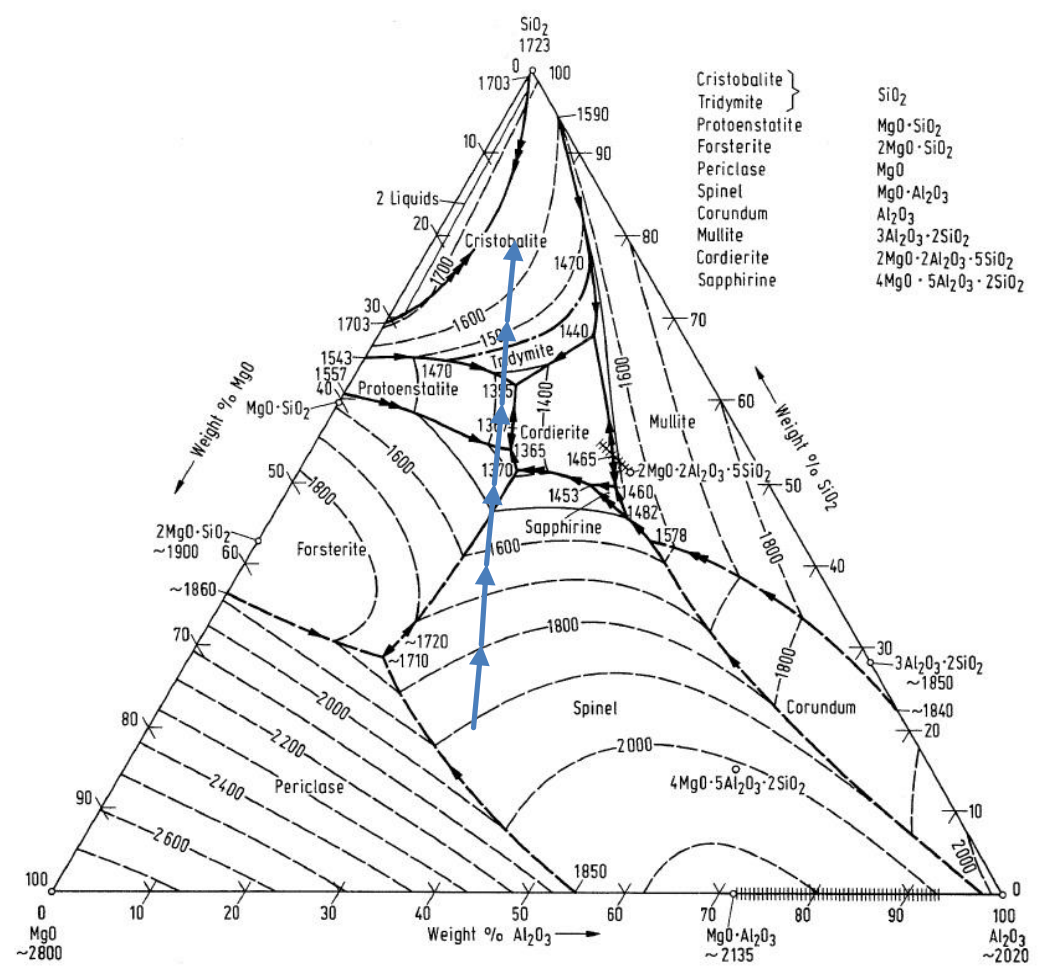

Figure 9: Ternary phase diagram for FeSiCr slag.

(Slag Atlas, 2008)

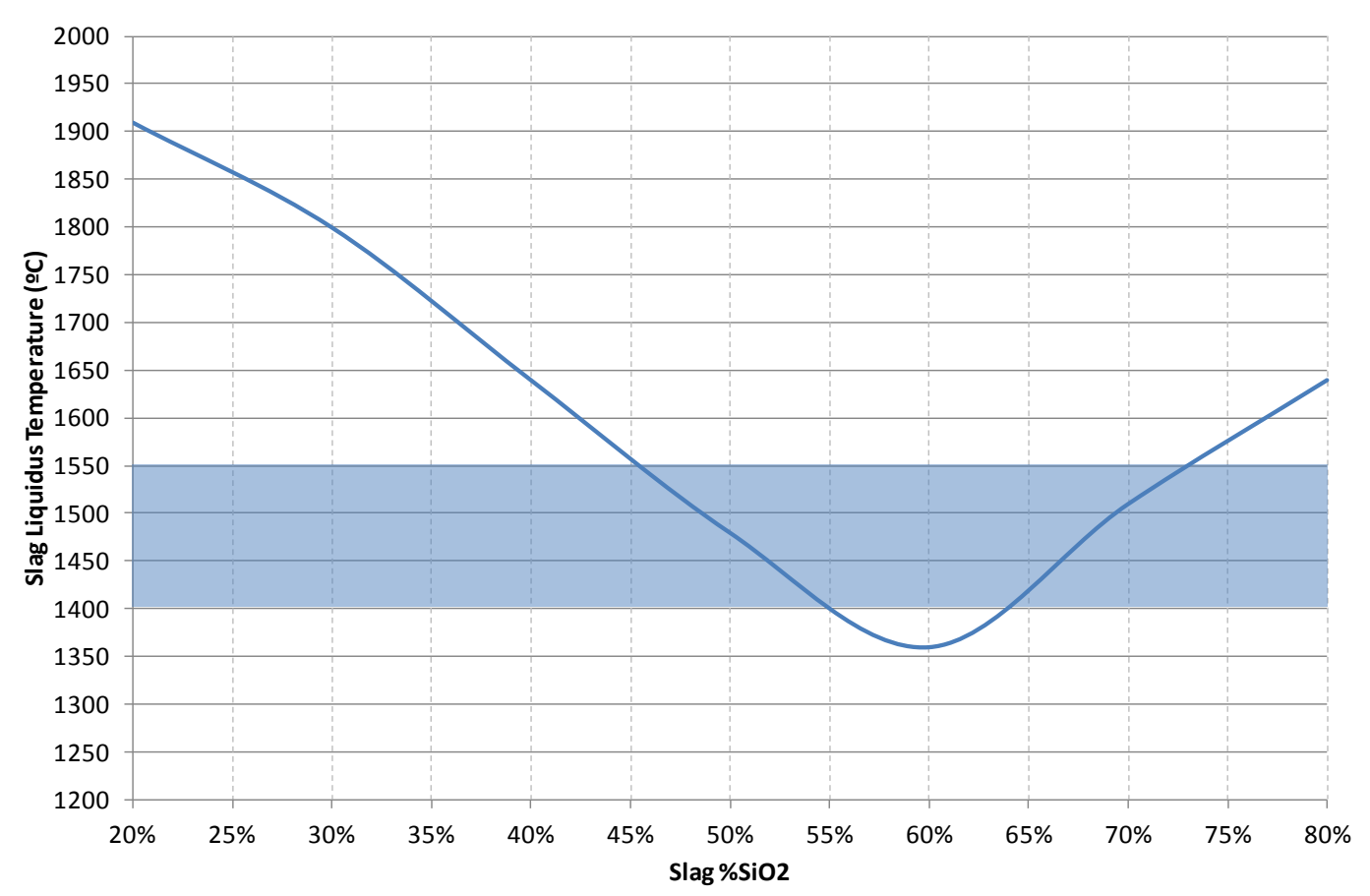

Figure 10: Liquidus temperature variation with slag $\mathrm{SiO}_{2}$ content.

\section{Page 18}

(C) University of Pretoria 
A slag superheat of between 50 and 200 degrees Celsius (Kennedy, 2012) is generally required to ensure that the slag can be tapped easily, while maintaining the refractory integrity. The tapping temperature of the FeSiCr slag is approximately $1600^{\circ} \mathrm{C}$, which means that a slag liquidus temperature of between 1400 and $1550^{\circ} \mathrm{C}$ should be suitable. This corresponds to a slag $\mathrm{SiO}_{2}$ content of between 45.5 and $55.0 \%$, and between 64.0 and $73.0 \%$. Considering that a higher quartzite addition would result in higher energy consumption and larger slag volume, the lower range of 45.5 to $55.0 \%$ is the preferred range.

The assumptions made in developing the mass and energy balance for $\mathrm{FeSiCr}$ production are listed and discussed in Table 4.

Table 4: Assumptions for FeSiCr mass and energy balance.

\begin{tabular}{|l|l|}
\hline Assumption & Reason \\
\hline $\begin{array}{l}\text { CrO and } \mathrm{FeO} \text { in slag } \\
\text { were fixed at } 0.5 \% .\end{array}$ & $\begin{array}{l}\text { Iron and chromium would be nearly completely reduced } \\
\text { in the presence of Si. A small percentage was retained } \\
\text { in the slag to allow for some kinetic limitations. }\end{array}$ \\
\hline $\begin{array}{l}\text { No SiC was assumed to } \\
\text { have formed. }\end{array}$ & $\begin{array}{l}\text { As this remains in the solid state, a build-up of SiC } \\
\text { would make the furnace inoperable within a short } \\
\text { period of time. As this doesn't happen in a well } \\
\text { controlled operation, all of the SiC was assumed to } \\
\text { have reacted with SiO } 2 .\end{array}$ \\
\hline $\begin{array}{l}\text { Only sufficient air was } \\
\text { introduced into the model } \\
\text { to react with the volatile } \\
\text { component of the coke. }\end{array}$ & $\begin{array}{l}\text { The combustion of the off-gas was excluded from the } \\
\text { balance, as it does not contribute energy to the } \\
\text { reaction. In practice, the energy from combustion does } \\
\text { assist in pre-heating the fresh feed material, which } \\
\text { improves the thermal efficiency of the process } \\
\text { somewhat. }\end{array}$ \\
\hline $\begin{array}{l}\text { All of the raw materials } \\
\text { were assumed to have } \\
\text { been dried, except for } \\
\text { the coke. }\end{array}$ & $\begin{array}{l}\text { Raw materials need to be dried in order to decrease the } \\
\text { energy requirement. Coke would not have been dried } \\
\text { due to the risk of oxidation at elevated temperatures. }\end{array}$ \\
\hline
\end{tabular}




\begin{tabular}{|l|l|}
\hline Assumption & Reason \\
\hline $\begin{array}{l}\text { The off-gas temperature } \\
\text { was selected to be } \\
1600^{\circ} \mathrm{C}, \text { which is the } \\
\text { same as that of the slag. }\end{array}$ & $\begin{array}{l}\text { In practice, the rising gas will heat the cold feed } \\
\text { materials, which means that the off-gas will be colder } \\
\text { and the raw materials hotter. However, keeping the } \\
\text { temperatures of the feed and gas at their original values } \\
\left(25 \text { and } 1600^{\circ} \mathrm{C} \text {, respectively) makes no difference to }\right. \\
\text { the process energy balance and simplified the } \\
\text { calculations. }\end{array}$ \\
\hline $\begin{array}{l}\text { The mass of iron rods } \\
\text { added was 5.3\% of the } \\
\text { alloy produced. }\end{array}$ & $\begin{array}{l}\text { Iron rods are used to keep the tap hole open and are } \\
\text { taken up in the alloy. It has therefore been added to the } \\
\text { mass balance as it is a significant source of iron. The } \\
\text { amount of iron added in the form of rods has been } \\
\text { calculated based on data collected on an existing plant. }\end{array}$ \\
\hline $\begin{array}{l}\mathrm{SiO}_{2} \text { target in slag was } \\
48 \% .\end{array}$ & $\begin{array}{l}\text { The slag composition was selected to be compatible } \\
\text { with the operating temperature of } 1600^{\circ} \mathrm{C} \text { (Figure 10). }\end{array}$ \\
\hline
\end{tabular}

The inputs and outputs of the FeSiCr production process are shown in Figure 11 and the results of the FeSiCr model are shown in Table 5.

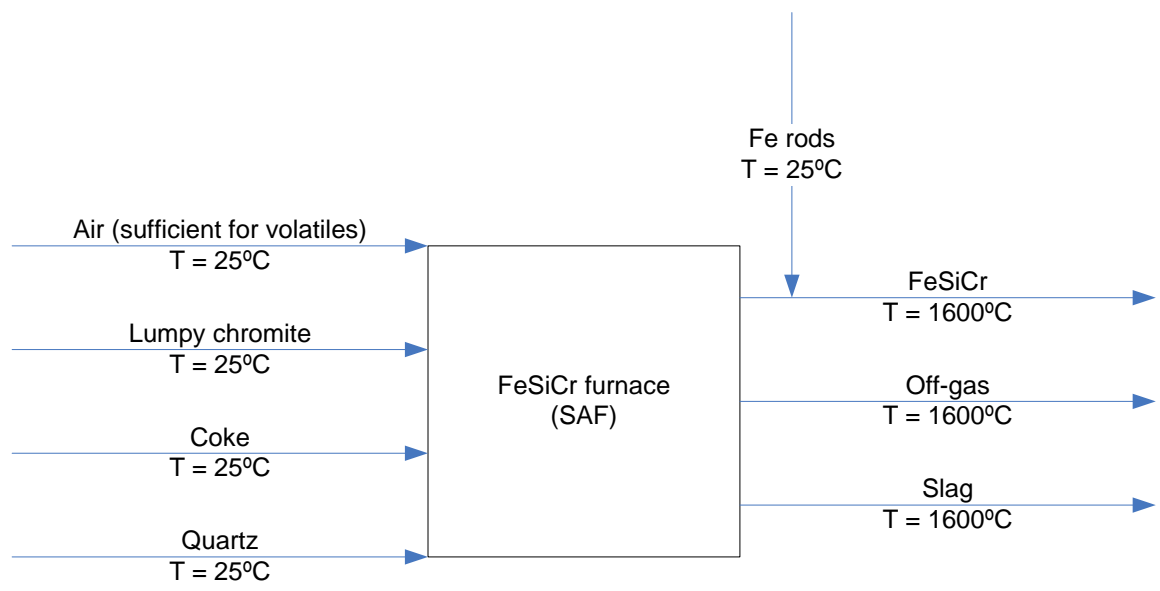

Figure 11: Inputs and outputs to the FeSiCr production process. 
Table 5: FeSiCr mass and energy balance.

(HSC Chemistry 7.1)

\begin{tabular}{|l|r|r|r|r|}
\hline Chromite & \multicolumn{1}{c|}{ wt \% } & \multicolumn{1}{c|}{ kg } & kmol & kWh \\
\hline Total & $\mathbf{1 0 0 . 0 0 \%}$ & $\mathbf{1 2 0 8}$ & & $\mathbf{- 3 3 7 7}$ \\
\hline $\mathrm{Al} 2 \mathrm{O} 3$ & $10.89 \%$ & 132 & 1.291 & -601 \\
\hline $\mathrm{CaO}$ & $0.36 \%$ & 4 & 0.078 & -14 \\
\hline $\mathrm{Cr} 2 \mathrm{O} 3$ & $48.71 \%$ & 589 & 3.873 & -1226 \\
\hline Fe2O3 & $14.50 \%$ & 175 & 1.097 & -252 \\
\hline $\mathrm{MgO}$ & $18.52 \%$ & 224 & 5.552 & -928 \\
\hline $\mathrm{SiO} 2$ & $7.02 \%$ & 85 & 1.412 & -357 \\
\hline
\end{tabular}

\begin{tabular}{|l|r|r|r|r|}
\hline FeSiCr & \multicolumn{1}{|c|}{ wt \% } & \multicolumn{1}{c|}{ kg } & \multicolumn{1}{c|}{ kmol } & \multicolumn{1}{c|}{ kWh } \\
\hline Total & $\mathbf{1 0 0 . 0 0 \%}$ & $\mathbf{1 0 0 0}$ & & $\mathbf{6 2 1}$ \\
\hline $\mathrm{Cr}(\mathrm{I})$ & $40.00 \%$ & 400 & 7.693 & 173 \\
\hline $\mathrm{Fe}(\mathrm{l})$ & $18.00 \%$ & 180 & 3.223 & 68 \\
\hline $\mathrm{Si}(\mathrm{I})$ & $42.00 \%$ & 420 & 14.954 & 380 \\
\hline
\end{tabular}

\begin{tabular}{|l|r|r|r|r|}
\hline Slag & \multicolumn{1}{c|}{ wt \% } & \multicolumn{1}{c|}{ kg } & kmol & \multicolumn{1}{c|}{ kWh } \\
\hline Total & $\mathbf{1 0 0 . 0 0 \%}$ & $\mathbf{7 9 2}$ & & $\mathbf{- 2 7 6 2}$ \\
\hline $\mathrm{Al} 2 \mathrm{O} 3(\mathrm{I})$ & $21.35 \%$ & 169 & 1.659 & -630 \\
\hline $\mathrm{CaO}(\mathrm{I})$ & $0.97 \%$ & 8 & 0.138 & -18 \\
\hline $\mathrm{Cr} 2 \mathrm{O} 3(\mathrm{I})$ & $0.50 \%$ & 4 & 0.026 & -6 \\
\hline $\mathrm{FeO}(\mathrm{I})$ & $0.50 \%$ & 4 & 0.055 & -2 \\
\hline $\mathrm{MgO}(\mathrm{I})$ & $28.68 \%$ & 227 & 5.636 & -713 \\
\hline $\mathrm{SiO} 2(\mathrm{I})$ & $48.00 \%$ & 380 & 6.328 & -1393 \\
\hline
\end{tabular}

\begin{tabular}{|l|r|r|r|r|}
\hline Coke & \multicolumn{1}{|c|}{ wt \% } & \multicolumn{1}{c|}{ kg } & kmol & kWh \\
\hline Total & $\mathbf{1 0 0 . 0 0 \%}$ & $\mathbf{7 0 1}$ & & $-\mathbf{4 3 7}$ \\
\hline $\mathrm{Al} 2 \mathrm{O} 3$ & $3.36 \%$ & 24 & 0.231 & -107 \\
\hline $\mathrm{C}$ & $83.47 \%$ & 585 & 48.703 & 0 \\
\hline $\mathrm{C} 6 \mathrm{H} 6$ (BZE) & $0.96 \%$ & 7 & 0.086 & 1 \\
\hline $\mathrm{CaO}$ & $0.48 \%$ & 3 & 0.060 & -11 \\
\hline $\mathrm{H} 2 \mathrm{O}(\mathrm{I})$ & $4.05 \%$ & 28 & 1.577 & -125 \\
\hline $\mathrm{FeO}$ & $1.44 \%$ & 10 & 0.140 & -11 \\
\hline $\mathrm{MgO}$ & $0.48 \%$ & 3 & 0.083 & -14 \\
\hline $\mathrm{SiO} 2$ & $5.76 \%$ & 40 & 0.671 & -170 \\
\hline
\end{tabular}

\begin{tabular}{|l|r|r|r|r|}
\hline Quartz & \multicolumn{1}{|c|}{ wt \% } & \multicolumn{1}{c|}{ kg } & kmol & \multicolumn{1}{c|}{ kWh } \\
\hline Total & $\mathbf{1 0 0 . 0 0 \%}$ & $\mathbf{1 4 0 1}$ & & -5903 \\
\hline Al2O3 & $1.00 \%$ & 14 & 0.137 & -64 \\
\hline SiO2 & $99.00 \%$ & 1387 & 23.078 & -5839 \\
\hline
\end{tabular}

\begin{tabular}{|l|r|r|r|r|}
\hline Off-gas & \multicolumn{1}{c|}{ wt \% } & \multicolumn{1}{c|}{ kg } & kmol & \multicolumn{1}{c|}{ kWh } \\
\hline Total & $\mathbf{1 0 0 . 0 0 \%}$ & $\mathbf{1 6 6 8}$ & & $\mathbf{- 9 3 8}$ \\
\hline $\mathrm{CO}(\mathrm{g})$ & $81.79 \%$ & 1364 & 48.703 & $-\mathbf{7 9 2}$ \\
\hline $\mathrm{CO} 2(\mathrm{~g})$ & $1.36 \%$ & 23 & 0.516 & -44 \\
\hline $\mathrm{H} 2 \mathrm{O}(\mathrm{g})$ & $1.98 \%$ & 33 & 1.835 & -89 \\
\hline $\mathrm{O} 2(\mathrm{~g})$ & $0.12 \%$ & 2 & 0.065 & 1 \\
\hline $\mathrm{N} 2(\mathrm{~g})$ & $4.49 \%$ & 75 & 2.672 & 38 \\
\hline $\mathrm{SiO}(\mathrm{g})$ & $10.25 \%$ & 171 & 3.879 & -51 \\
\hline
\end{tabular}

\begin{tabular}{|l|r|r|r|r|r|}
\hline Air & \multicolumn{1}{|c|}{ wt \% } & \multicolumn{1}{|c|}{ kg } & kmol & kWh & Nm3/h \\
\hline Total & $\mathbf{1 0 0 . 0 0 \%}$ & $\mathbf{9 8}$ & & $\mathbf{0}$ & $\mathbf{7 6}$ \\
\hline O2(g) & $21.00 \%$ & 23 & 0.710 & 0 & 16 \\
\hline N2(g) & $79.00 \%$ & 75 & 2.672 & 0 & 60 \\
\hline
\end{tabular}

\begin{tabular}{|l|c|r|r|r|}
\hline Fe rods & wt $\%$ & \multicolumn{1}{c|}{ kg } & kmol & \multicolumn{1}{c|}{ kWh } \\
\hline Total & $\mathbf{1 0 0 . 0 0 \%}$ & $\mathbf{5 3}$ & & $\mathbf{0}$ \\
\hline Fe & $100.00 \%$ & 53 & 0.944 & 0 \\
\hline
\end{tabular}

\section{Consumptions}

\begin{tabular}{|l|l|r|}
\hline Chromite & $\mathrm{kg} / \mathrm{t} \mathrm{FeSiCr}$ & 1208 \\
\hline Coke & $\mathrm{kg} / \mathrm{t} \mathrm{FeSiCr}$ & 701 \\
\hline Quartzite & $\mathrm{kg} / \mathrm{t} \mathrm{FeSiCr}$ & 1401 \\
\hline Energy (SER) & $\mathrm{kWh} / \mathrm{t} \mathrm{FeSiCr}$ & 6638 \\
\hline
\end{tabular}

\section{Page 21}


Consumption figures from literature were obtained for comparative purposes. These are shown in Table 6.

Table 6: FeSiCr production parameters from literature.

\begin{tabular}{|l|c|c|l|}
\hline Parameter & Unit & Value & \multicolumn{1}{|c|}{ Reference } \\
\hline Chromite & $\begin{array}{c}\mathrm{kg} / \mathrm{t} \\
\mathrm{FeSiCr}\end{array}$ & $\begin{array}{l}1145 \\
1000\end{array}$ & $\begin{array}{l}\text { Gasik, 2013 } \\
\text { Robiette, 1973 }\end{array}$ \\
\hline Quartzite & $\begin{array}{c}\mathrm{kg} / \mathrm{t} \\
\mathrm{FeSiCr}\end{array}$ & 1323 & Gasik, 2013 \\
& 1100 & Robiette, 1973 \\
\hline Coke & $\mathrm{kg} / \mathrm{t}$ & 678 & Gasik, 2013 \\
$\mathrm{FeSiCr}$ & 650 & Robiette, 1973 \\
\hline $\begin{array}{l}\text { Energy requirement } \\
\text { (specific) }\end{array}$ & $\begin{array}{c}\mathrm{kWh} / \mathrm{t} \\
\mathrm{FeSiCr}\end{array}$ & $6200-6500$ & McDougall, 2013 \\
\hline $\begin{array}{l}\text { Energy requirement } \\
\text { (gross) }\end{array}$ & $\begin{array}{c}\mathrm{kWh} / \mathrm{t} \\
\mathrm{FeSiCr}\end{array}$ & $6890-7220$ & McDougall, 2013 (calculated from) \\
& $6890-9030$ & European IPPC Bureau, 2001 \\
\hline
\end{tabular}

Although the raw material consumptions are slightly higher $(3.4-5.9 \%)$ than the values quoted by Gasik, it is considered to be within a reasonable range. It should, however, be noted that the model does not consider the combustion of the $\mathrm{CO}$ and $\mathrm{SiO}$ gas in the furnace freeboard area. The pre-heating effect that this gas has on the raw material feed, as well as the subsequent reduction in the energy requirement, has therefore not been included.

One would expect the chromite consumption to vary somewhat depending on the analysis of the ore used. A $\mathrm{Cr} / \mathrm{Fe}$ ratio of at least 2.5 is required to produce a LC FeCr product containing $70 \% \mathrm{Cr}$. Ferrochrome silicide has only two uses, namely directly in steelmaking and as reductant in the production of low carbon ferrochrome (Gasik, 2013). It therefore stands to reason that only ores with a $\mathrm{Cr} / \mathrm{Fe}$ ratio of more than 2.5 will be used for the production of FeSiCr. Using the values quoted in Table 6 would therefore offer a reasonable basis for comparison.

\subsubsection{Mixing Method}

The final slag basicity in the Mixing Method is dependent on the amount of lime that is added to the ore-lime melt. $\mathrm{CaO}$ is added to chromite in the Mixing Method in order to decrease the liquidus temperature of the ore (Figure 12). At an existing operation 
in Turkey, the target $\% \mathrm{Cr}_{2} \mathrm{O}_{3}$ in their Perrin Process is $27 \%$, which is in line with that published by other authors (Gasik, 2013)(Ghose, et al., 1983). The resulting slag has a basicity of between 2.0 and 2.5. This was used in the mass and energy balance for the Mixing Method (Duplex and Perrin Processes).

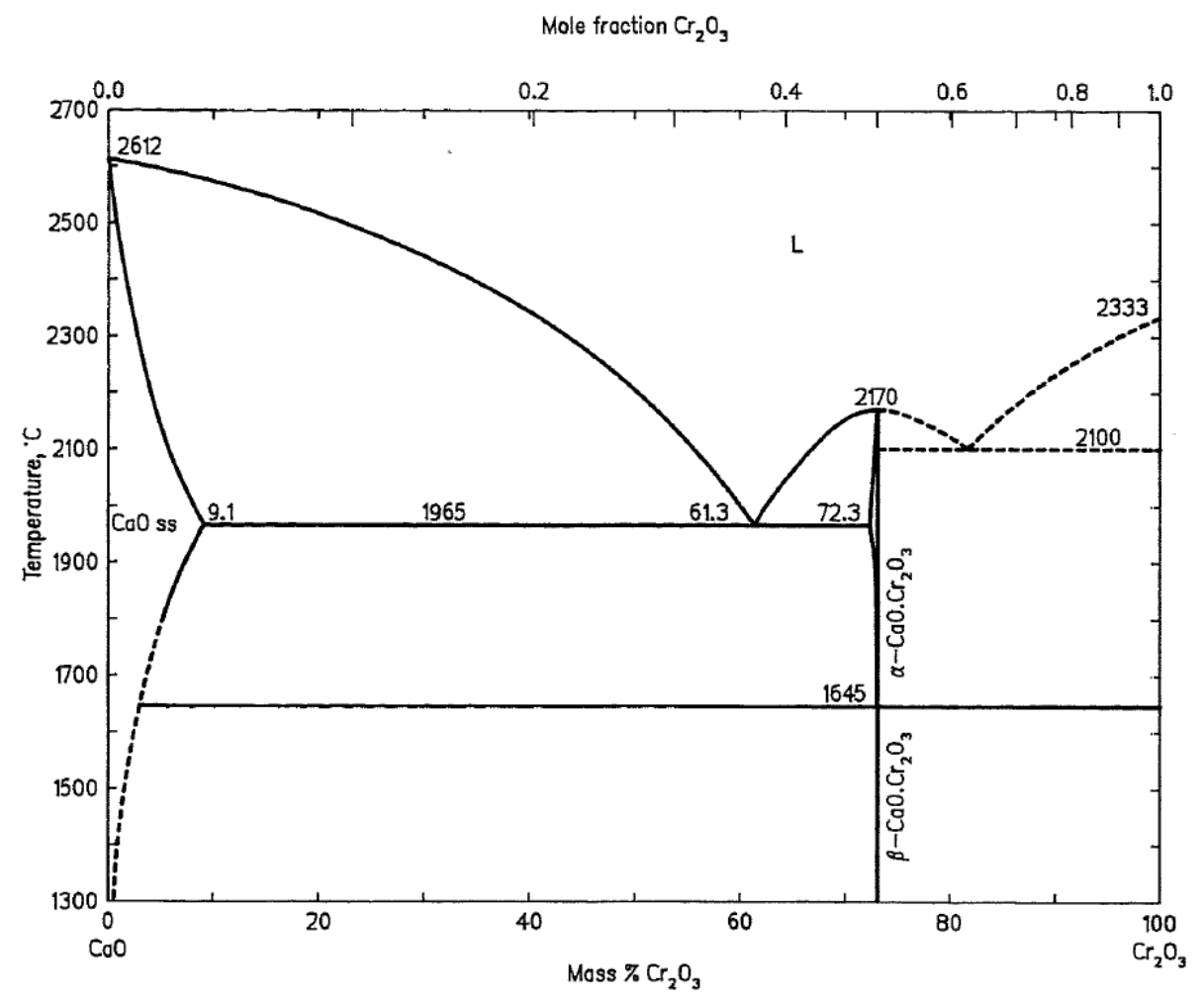

Figure 12: $\mathrm{CaO}-\mathrm{Cr}_{2} \mathrm{O}_{3}$ binary phase diagram.

(Slag Atlas, 2008)

FactSage modelling indicated the liquidus temperature of the $27 \% \mathrm{Cr}_{2} \mathrm{O}_{3}$ slag to be approximately $1831^{\circ} \mathrm{C}$. The temperature of the ore-lime melt was not measured at the reference facility and was therefore assumed to be $1900^{\circ} \mathrm{C}$, which is in agreement with values quoted by Gasik (2013). All raw materials were assumed to enter the furnace at $25^{\circ} \mathrm{C}$.

The inputs for the Perrin and Duplex models were similar, except that the $\mathrm{Cr}_{2} \mathrm{O}_{3}$ in the slag was $2 \%$ and 3\% for the Perrin (Table 8) and Duplex (Table 9) processes, respectively.

The assumptions made in developing the mass and energy balances for the Mixing Method processes are listed and discussed in Table 7. 
Table 7: Assumptions for Mixing Method mass and energy balances.

\begin{tabular}{|l|l|}
\hline Assumption & Reason \\
\hline $\begin{array}{l}\text { The } \mathrm{Cr}_{2} \mathrm{O}_{3} \text { content of the } \\
\text { ore-lime melt was 27\%. }\end{array}$ & $\begin{array}{l}\text { This is the target composition at the reference plant, as } \\
\text { well as that quoted in literature (Gasik, 2013). }\end{array}$ \\
\hline $\begin{array}{l}\text { The final slag } \mathrm{Cr}_{2} \mathrm{O}_{3} \\
\text { content was } 2 \% \text { for the } \\
\begin{array}{l}\text { Perrin process and 3\% } \\
\text { for the Duplex process. }\end{array}\end{array}$ & $\begin{array}{l}\text { These values are typically targeted in industry } \\
\text { (Robiette, 1973 and Ghose, et al., 1983). Reaction } \\
\text { kinetics for the Duplex process is expected to be slower } \\
\text { due to the use of solid FeSiCr. }\end{array}$ \\
\hline
\end{tabular}

The inputs and outputs of the LC FeCr production process are illustrated in Figure 13. Note that chromium in the slag is expressed as $\mathrm{CrO}$, as thermochemical modelling results indicated that almost all of the chromium in the slag would be in the Cr(II) oxidation state.

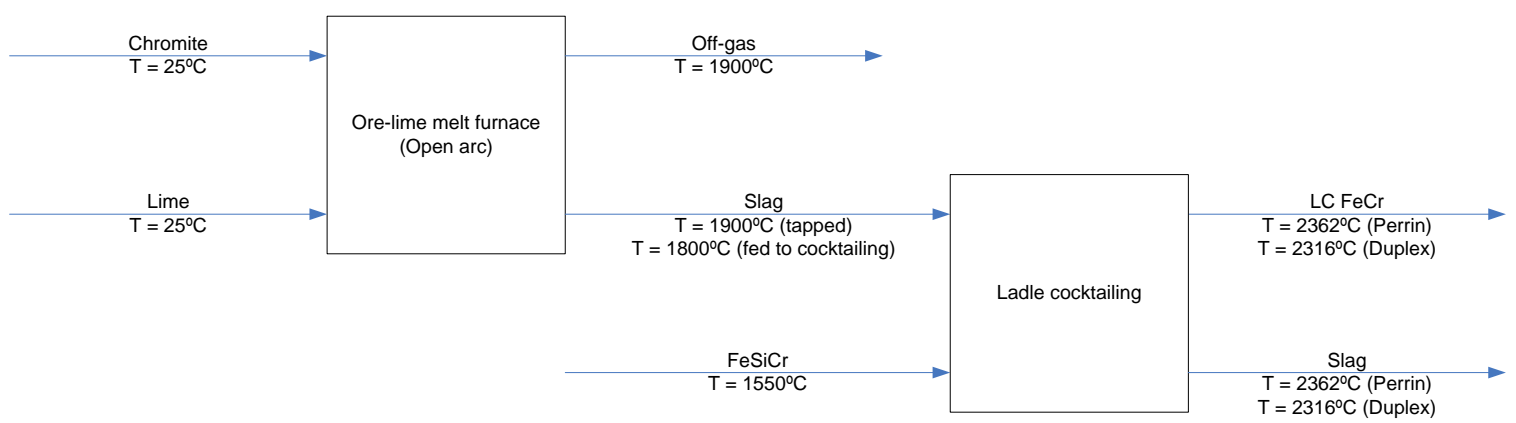

Figure 13: Inputs and outputs to the LC FeCr production process (Mixing Method). 
Table 8: Mixing Method (Perrin Process) mass and energy balance.

(HSC Chemistry 7.1)

Ore-lime melt

\begin{tabular}{|l|r|r|r|r|}
\hline Chromite & \multicolumn{1}{|c|}{ wt \% } & \multicolumn{1}{|c|}{ kg } & kmol & kWh \\
\hline Total & $\mathbf{1 0 0 . 0 0 \%}$ & $\mathbf{1 4 9 7}$ & & $\mathbf{- 4 1 8 4}$ \\
\hline $\mathrm{Al} 2 \mathrm{O} 3$ & $10.89 \%$ & 163 & 1.599 & -744 \\
\hline $\mathrm{CaO}$ & $0.36 \%$ & 5 & 0.096 & -17 \\
\hline $\mathrm{Cr} 2 \mathrm{O} 3$ & $48.71 \%$ & 729 & 4.798 & -1519 \\
\hline $\mathrm{Fe} 2 \mathrm{O} 3$ & $14.50 \%$ & 217 & 1.359 & -312 \\
\hline $\mathrm{MgO}$ & $18.52 \%$ & 277 & 6.879 & -1150 \\
\hline $\mathrm{SiO} 2$ & $7.02 \%$ & 105 & 1.749 & -443 \\
\hline
\end{tabular}

\begin{tabular}{|l|r|r|r|r|}
\hline Lime & \multicolumn{1}{|c|}{ wt $\%$} & \multicolumn{1}{|c|}{ kg } & kmol & kWh \\
\hline Total & $\mathbf{1 0 0 . 0 0 \%}$ & $\mathbf{1 2 1 6}$ & & $\mathbf{- 3 8 4 7}$ \\
\hline $\mathrm{Al} 2 \mathrm{O} 3$ & $0.00 \%$ & 0 & 0.000 & 0 \\
\hline $\mathrm{CaO}$ & $96.33 \%$ & 1171 & 20.887 & -3684 \\
\hline $\mathrm{Cr} 2 \mathrm{O} 3$ & $0.00 \%$ & 0 & 0.000 & 0 \\
\hline $\mathrm{FeO}$ & $0.00 \%$ & 0 & 0.000 & 0 \\
\hline $\mathrm{MgO}$ & $0.90 \%$ & 11 & 0.272 & -45 \\
\hline $\mathrm{SiO} 2$ & $0.50 \%$ & 6 & 0.101 & -26 \\
\hline $\mathrm{CaCO} 3$ & $2.27 \%$ & 28 & 0.276 & -93 \\
\hline
\end{tabular}

\section{Cocktailing (LC FeCr production)}

\begin{tabular}{|l|r|r|r|r|}
\hline FeSiCr & \multicolumn{1}{|c|}{ wt \% } & \multicolumn{1}{|c|}{ kg } & kmol & \multicolumn{1}{c|}{ kWh } \\
\hline Total & $\mathbf{1 0 0 . 0 0 \%}$ & $\mathbf{6 3 2}$ & & $\mathbf{3 8 4}$ \\
\hline $\mathrm{Cr}(\mathrm{I})$ & $40.00 \%$ & 253 & 4.865 & 106 \\
\hline $\mathrm{Fe}(\mathrm{I})$ & $18.00 \%$ & 114 & 2.038 & 41 \\
\hline $\mathrm{Si}(\mathrm{I})$ & $42.00 \%$ & 266 & 9.457 & 237 \\
\hline
\end{tabular}

\begin{tabular}{|l|r|r|r|r|}
\hline Slag & \multicolumn{1}{|c|}{ wt \% } & \multicolumn{1}{|c|}{ kg } & kmol & \multicolumn{1}{c|}{ kWh } \\
\hline Total & $\mathbf{1 0 0 . 0 0 \%}$ & $\mathbf{2 7 0 1}$ & & $\mathbf{- 5 8 4 4}$ \\
\hline $\mathrm{Al} 2 \mathrm{O} 3(\mathrm{I})$ & $6.04 \%$ & 163 & $\mathbf{1 . 5 9 9}$ & -594 \\
\hline $\mathrm{CaO}(\mathrm{I})$ & $44.14 \%$ & 1192 & $\mathbf{2 1 . 2 5 9}$ & -2725 \\
\hline $\mathrm{Cr2O}(\mathrm{I})$ & $27.00 \%$ & 729 & $\mathbf{4 . 7 9 8}$ & -1033 \\
\hline $\mathrm{CrO}(\mathrm{I})$ & $0.00 \%$ & 0 & 0.000 & 0 \\
\hline $\mathrm{Fe} 2 \mathrm{O} 3$ & $8.04 \%$ & 217 & $\mathbf{1 . 3 5 9}$ & -214 \\
\hline $\mathrm{FeO}(\mathrm{I})$ & $0.00 \%$ & 0 & $\mathbf{0 . 0 0 0}$ & 0 \\
\hline $\mathrm{MgO}(\mathrm{I})$ & $10.67 \%$ & 288 & $\mathbf{7 . 1 5 1}$ & -878 \\
\hline $\mathrm{SiO} 2(\mathrm{I})$ & $4.12 \%$ & 111 & $\mathbf{1 . 8 5 0}$ & -398 \\
\hline
\end{tabular}

\section{Consumptions}

\begin{tabular}{|l|l|r|}
\hline Chromite & $\mathrm{kg} / \mathrm{t} \mathrm{LC} \mathrm{FeCr}$ & 1497 \\
\hline Lime & $\mathrm{kg} / \mathrm{t} \mathrm{LC} \mathrm{FeCr}$ & 1216 \\
\hline FeSiCr & $\mathrm{kg} / \mathrm{t} \mathrm{LC} \mathrm{FeCr}$ & 632 \\
\hline Energy (SER) & $\mathrm{kWh} / \mathrm{t} \mathrm{LC} \mathrm{FeCr}$ & 2254 \\
\hline
\end{tabular}

\begin{tabular}{|l|r|r|r|r|}
\hline Slag & \multicolumn{1}{c|}{ wt \% } & \multicolumn{1}{c|}{ kg } & kmol & \multicolumn{1}{c|}{ kWh } \\
\hline Total & $\mathbf{1 0 0 . 0 0 \%}$ & $\mathbf{2 7 0 1}$ & & $\mathbf{- 5 7 5 6}$ \\
\hline $\mathrm{Al} 2 \mathrm{O} 3(\mathrm{I})$ & $6.04 \%$ & 163 & 1.599 & -588 \\
\hline $\mathrm{CaO}(\mathrm{I})$ & $44.14 \%$ & 1192 & 21.259 & -2688 \\
\hline $\mathrm{Cr} 2 \mathrm{O} 3(\mathrm{I})$ & $27.00 \%$ & 729 & 4.798 & -1012 \\
\hline $\mathrm{CrO}(\mathrm{I})$ & $0.00 \%$ & 0 & 0.000 & 0 \\
\hline $\mathrm{FeO}(\mathrm{I})$ & $0.00 \%$ & 0 & 0.000 & 0 \\
\hline $\mathrm{Fe} 2 \mathrm{O} 3$ & $8.04 \%$ & 217 & 1.359 & -208 \\
\hline $\mathrm{MgO}(\mathrm{I})$ & $10.67 \%$ & 288 & 7.151 & -865 \\
\hline $\mathrm{SiO} 2(\mathrm{I})$ & $4.12 \%$ & 111 & 1.850 & -394 \\
\hline
\end{tabular}

\begin{tabular}{|l|c|r|r|r|}
\hline Off-gas & wt \% & \multicolumn{1}{|c|}{ kg } & \multicolumn{1}{c|}{ kmol } & \multicolumn{1}{c|}{ kWh } \\
\hline Total & $\mathbf{1 0 0 . 0 0 \%}$ & $\mathbf{1 2}$ & & $\mathbf{- 2 2}$ \\
\hline CO2(g) & $100.00 \%$ & 12 & 0.276 & -22 \\
\hline
\end{tabular}

\begin{tabular}{|l|r|r|r|r|}
\hline Metal & \multicolumn{1}{|c|}{ wt \% } & \multicolumn{1}{c|}{ kg } & kmol & \multicolumn{1}{c|}{ kWh } \\
\hline Total & $\mathbf{1 0 0 . 0 0 \%}$ & $\mathbf{1 0 0 0}$ & & $\mathbf{6 2 0}$ \\
\hline $\mathrm{Cr}(\mathrm{I})$ & $\mathbf{7 2 . 0 0 \%}$ & $\mathbf{7 2 0}$ & 13.847 & 458 \\
\hline $\mathrm{Fe}(\mathrm{I})$ & $26.50 \%$ & $\mathbf{2 6 5}$ & 4.745 & 146 \\
\hline $\mathbf{S i}(\mathrm{I})$ & $1.50 \%$ & $\mathbf{1 5}$ & 0.534 & 17 \\
\hline
\end{tabular}

\begin{tabular}{|l|r|r|r|r|}
\hline Slag & \multicolumn{1}{c|}{ wt \% } & \multicolumn{1}{c|}{ kg } & kmol & kWh \\
\hline Total & $\mathbf{1 0 0 . 0 0 \%}$ & $\mathbf{2 3 3 3}$ & & $\mathbf{- 6 0 8 0}$ \\
\hline $\mathrm{Al} 2 \mathrm{O} 3(\mathrm{I})$ & $6.99 \%$ & 163 & $\mathbf{1 . 5 9 9}$ & -558 \\
\hline $\mathrm{CaO}(\mathrm{I})$ & $51.09 \%$ & 1192 & $\mathbf{2 1 . 2 5 9}$ & -2517 \\
\hline $\mathrm{Cr2O3}(\mathrm{I})$ & $0.00 \%$ & $\mathbf{0}$ & 0.000 & 0 \\
\hline $\mathrm{CrO}(\mathrm{I})$ & $1.79 \%$ & 42 & 0.614 & -25 \\
\hline $\mathrm{Fe} 2 \mathrm{O} 3(\mathrm{I})$ & $0.00 \%$ & 0 & $\mathbf{0 . 0 0 0}$ & 0 \\
\hline $\mathrm{FeO}(\mathrm{I})$ & $0.04 \%$ & 1 & $\mathbf{0 . 0 1 2}$ & 0 \\
\hline $\mathrm{MgO}(\mathrm{I})$ & $12.35 \%$ & 288 & $\mathbf{7 . 1 5 1}$ & -804 \\
\hline $\mathrm{SiO}(\mathrm{I})$ & $27.74 \%$ & 647 & $\mathbf{1 0 . 7 7 4}$ & -2176 \\
\hline
\end{tabular}

\section{Page 25}


Table 9: Mixing Method (Duplex Process) mass and energy balance.

(HSC Chemistry 7.1)

Ore-lime melt

\begin{tabular}{|l|r|r|r|r|}
\hline Chromite & \multicolumn{1}{c|}{ wt \% } & \multicolumn{1}{|c|}{ kg } & kmol & kWh \\
\hline Total & $\mathbf{1 0 0 . 0 0 \%}$ & $\mathbf{1 5 4 5}$ & & $-\mathbf{4 3 1 8}$ \\
\hline $\mathrm{Al} 2 \mathrm{O} 3$ & $10.89 \%$ & 168 & 1.650 & -768 \\
\hline $\mathrm{CaO}$ & $0.36 \%$ & 6 & 0.099 & -17 \\
\hline $\mathrm{Cr} 2 \mathrm{O} 3$ & $48.71 \%$ & 753 & 4.951 & -1567 \\
\hline $\mathrm{Fe} 2 \mathrm{O} 3$ & $14.50 \%$ & 224 & 1.403 & -322 \\
\hline $\mathrm{MgO}$ & $18.52 \%$ & 286 & 7.099 & -1186 \\
\hline $\mathrm{SiO} 2$ & $7.02 \%$ & 108 & 1.805 & -457 \\
\hline
\end{tabular}

\begin{tabular}{|l|r|r|r|r|}
\hline Slag & \multicolumn{1}{c|}{ wt \% } & \multicolumn{1}{c|}{ kg } & kmol & kWh \\
\hline Total & $\mathbf{1 0 0 . 0 0 \%}$ & $\mathbf{2 7 8 7}$ & & $\mathbf{- 5 9 3 9}$ \\
\hline $\mathrm{Al} 2 \mathrm{O} 3(\mathrm{I})$ & $6.04 \%$ & 168 & 1.650 & -607 \\
\hline $\mathrm{CaO}(\mathrm{I})$ & $44.14 \%$ & 1230 & 21.937 & -2774 \\
\hline $\mathrm{Cr} 2 \mathrm{O} 3(\mathrm{I})$ & $27.00 \%$ & 753 & 4.951 & -1045 \\
\hline $\mathrm{CrO}(\mathrm{I})$ & $0.00 \%$ & 0 & 0.000 & 0 \\
\hline $\mathrm{FeO}(\mathrm{I})$ & $0.00 \%$ & 0 & 0.000 & 0 \\
\hline $\mathrm{Fe} 2 \mathrm{O} 3$ & $8.04 \%$ & 224 & 1.403 & -215 \\
\hline $\mathrm{MgO}(\mathrm{I})$ & $10.67 \%$ & 297 & 7.379 & -893 \\
\hline $\mathrm{SiO} 2(\mathrm{I})$ & $4.12 \%$ & 115 & 1.909 & -407 \\
\hline
\end{tabular}

\begin{tabular}{|l|r|r|r|r|}
\hline Lime & \multicolumn{1}{|c|}{ wt \% } & \multicolumn{1}{|c|}{ kg } & kmol & kWh \\
\hline Total & $\mathbf{1 0 0 . 0 0 \%}$ & $\mathbf{1 2 5 5}$ & & $\mathbf{- 3 9 7 0}$ \\
\hline $\mathrm{Al} 2 \mathrm{O} 3$ & $0.00 \%$ & 0 & 0.000 & 0 \\
\hline $\mathrm{CaO}$ & $96.33 \%$ & 1209 & 21.553 & -3801 \\
\hline $\mathrm{Cr} 2 \mathrm{O} 3$ & $0.00 \%$ & 0 & 0.000 & 0 \\
\hline $\mathrm{FeO}$ & $0.00 \%$ & 0 & 0.000 & 0 \\
\hline $\mathrm{MgO}$ & $0.90 \%$ & 11 & 0.280 & -47 \\
\hline $\mathrm{SiO} 2$ & $0.50 \%$ & 6 & 0.104 & -26 \\
\hline $\mathrm{CaCO} 3$ & $2.27 \%$ & 29 & 0.285 & -96 \\
\hline
\end{tabular}

\begin{tabular}{|l|c|r|r|r|}
\hline Off-gas & wt \% & \multicolumn{1}{|c|}{ kg } & kmol & \multicolumn{1}{c|}{ kWh } \\
\hline Total & $\mathbf{1 0 0 . 0 0 \%}$ & $\mathbf{1 3}$ & & $\mathbf{- 2 3}$ \\
\hline CO2(g) & $100.00 \%$ & 13 & 0.285 & -23 \\
\hline
\end{tabular}

\section{Cocktailing (LC FeCr production)}

\begin{tabular}{|l|r|r|r|r|}
\hline FeSiCr & \multicolumn{1}{|c|}{ wt \% } & \multicolumn{1}{|c|}{ kg } & kmol & \multicolumn{1}{c|}{ kWh } \\
\hline Total & $\mathbf{1 0 0 . 0 0 \%}$ & $\mathbf{6 3 7}$ & & $\mathbf{3 5 1}$ \\
\hline $\mathrm{Cr}(\mathrm{I})$ & $40.00 \%$ & 255 & 4.902 & 71 \\
\hline $\mathrm{Fe}(\mathrm{I})$ & $18.00 \%$ & 115 & 2.054 & 42 \\
\hline $\mathrm{Si}(\mathrm{I})$ & $42.00 \%$ & 268 & 9.529 & 239 \\
\hline
\end{tabular}

\begin{tabular}{|l|r|r|r|r|}
\hline Metal & \multicolumn{1}{|c|}{ wt \% } & \multicolumn{1}{c|}{ kg } & kmol & \multicolumn{1}{c|}{ kWh } \\
\hline Total & $\mathbf{1 0 0 . 0 0 \%}$ & $\mathbf{1 0 0 0}$ & & $\mathbf{5 2 7}$ \\
\hline $\mathrm{Cr}(\mathrm{I})$ & $\mathbf{7 2 . 0 0 \%}$ & $\mathbf{7 2 0}$ & 13.847 & 388 \\
\hline $\mathrm{Fe}(\mathrm{I})$ & $\mathbf{2 6 . 5 0 \%}$ & $\mathbf{2 6 5}$ & 4.745 & 124 \\
\hline $\mathbf{S i}(\mathrm{I})$ & $\mathbf{1 . 5 0}$ & $\mathbf{1 5}$ & 0.534 & 15 \\
\hline
\end{tabular}

\begin{tabular}{|l|r|r|r|r|}
\hline Slag & \multicolumn{1}{|c|}{ wt \% } & \multicolumn{1}{|c|}{ kg } & kmol & \multicolumn{1}{c|}{ kWh } \\
\hline Total & $\mathbf{1 0 0 . 0 0 \%}$ & $\mathbf{2 7 8 7}$ & & $\mathbf{- 6 0 3 0}$ \\
\hline $\mathrm{Al} 2 \mathrm{O} 3(\mathrm{I})$ & $6.04 \%$ & 168 & 1.650 & -613 \\
\hline $\mathrm{CaO}(\mathrm{I})$ & $44.14 \%$ & 1230 & 21.937 & -2812 \\
\hline $\mathrm{Cr2O3}(\mathrm{I})$ & $27.00 \%$ & 753 & 4.951 & -1066 \\
\hline $\mathrm{CrO}(\mathrm{I})$ & $0.00 \%$ & 0 & 0.000 & 0 \\
\hline $\mathrm{Fe} 2 \mathrm{O} 3$ & $8.04 \%$ & 224 & 1.403 & -221 \\
\hline $\mathrm{FeO}(\mathrm{I})$ & $0.00 \%$ & 0 & 0.000 & 0 \\
\hline $\mathrm{MgO}(\mathrm{I})$ & $10.67 \%$ & 297 & 7.379 & -906 \\
\hline $\mathrm{SiO} 2(\mathrm{I})$ & $4.12 \%$ & 115 & 1.909 & -411 \\
\hline
\end{tabular}

\begin{tabular}{|l|r|r|r|r|}
\hline Slag & \multicolumn{1}{|c|}{ wt \% } & \multicolumn{1}{c|}{ kg } & kmol & \multicolumn{1}{c|}{ kWh } \\
\hline Total & $\mathbf{1 0 0 . 0 0 \%}$ & $\mathbf{2 4 2 4}$ & & $\mathbf{- 6 2 8 7}$ \\
\hline Al2O3(I) & $6.94 \%$ & 168 & $\mathbf{1 . 6 5 0}$ & -579 \\
\hline $\mathrm{CaO}(\mathrm{I})$ & $50.74 \%$ & 1230 & $\mathbf{2 1 . 9 3 7}$ & -2615 \\
\hline $\mathrm{Cr2O3}(\mathrm{I})$ & $0.00 \%$ & $\mathbf{0}$ & 0.000 & 0 \\
\hline $\mathrm{CrO}(\mathrm{I})$ & $2.68 \%$ & 65 & 0.957 & -40 \\
\hline $\mathrm{Fe} 2 \mathrm{O}(\mathrm{I})$ & $0.00 \%$ & 0 & $\mathbf{0 . 0 0 0}$ & 0 \\
\hline $\mathrm{FeO}(\mathrm{I})$ & $0.34 \%$ & 8 & $\mathbf{0 . 1 1 4}$ & -3 \\
\hline $\mathrm{MgO}(\mathrm{I})$ & $12.27 \%$ & 297 & $\mathbf{7 . 3 7 9}$ & -836 \\
\hline $\mathrm{SiO} 2(\mathrm{I})$ & $27.03 \%$ & 655 & $\mathbf{1 0 . 9 0 5}$ & -2214 \\
\hline
\end{tabular}

\section{Consumptions}

\begin{tabular}{|l|l|r|}
\hline Chromite & $\mathrm{kg} / \mathrm{t} \mathrm{LC} \mathrm{FeCr}$ & 1545 \\
\hline Lime & $\mathrm{kg} / \mathrm{t} \mathrm{LC} \mathrm{FeCr}$ & 1255 \\
\hline FeSiCr & $\mathrm{kg} / \mathrm{t} \mathrm{LC} \mathrm{FeCr}$ & 637 \\
\hline Energy (SER) & $\mathrm{kWh} / \mathrm{t} \mathrm{LC} \mathrm{FeCr}$ & 2326 \\
\hline
\end{tabular}

The comparative results from literature are shown in Table 10.

\section{Page 26}


Table 10: LC FeCr production parameters from literature.

\begin{tabular}{|c|c|c|c|}
\hline Parameter & Unit & Value & Reference \\
\hline Chromite & $\begin{array}{l}\mathrm{kg} / \mathrm{t} \mathrm{LC} \\
\mathrm{FeCr}\end{array}$ & $\begin{array}{c}1750 \\
1600 \\
1400-1500 \\
1440\end{array}$ & $\begin{array}{l}\text { Gasik, } 2013 \\
\text { European IPPC Bureau, } 2001 \\
\text { Ghose, et al., } 1983 \\
\text { Robiette, } 1973\end{array}$ \\
\hline $\mathrm{FeSiCr}$ & $\begin{array}{l}\mathrm{kg} / \mathrm{t} \mathrm{LC} \\
\mathrm{FeCr}\end{array}$ & $\begin{array}{c}570 \\
675 \\
660-700 \\
660\end{array}$ & $\begin{array}{l}\text { Gasik, } 2013 \\
\text { European IPPC Bureau, } 2001 \\
\text { Ghose, et al., } 1983 \\
\text { Robiette, } 1973\end{array}$ \\
\hline Lime & $\begin{array}{l}\mathrm{kg} / \mathrm{t} \mathrm{LC} \\
\mathrm{FeCr}\end{array}$ & $\begin{array}{c}1370 \\
1100 \\
1400-1457 \\
1250\end{array}$ & $\begin{array}{l}\text { Gasik, } 2013 \\
\text { European IPPC Bureau, } 2001 \\
\text { Ghose, et al., } 1983 \\
\text { Robiette, } 1973\end{array}$ \\
\hline $\begin{array}{l}\text { Energy requirement } \\
\text { (gross) }\end{array}$ & $\begin{array}{l}\mathrm{kWh} / \mathrm{t} \mathrm{LC} \\
\mathrm{FeCr}\end{array}$ & $\begin{array}{l}3350-3540 \\
3400 \\
3200-3500 \\
3200\end{array}$ & $\begin{array}{l}\text { Basson, et al., } 2007 \text { (calculated from) } \\
\text { European IPPC Bureau, } 2001 \\
\text { Ghose, et al., } 1983 \\
\text { Robiette, } 1973\end{array}$ \\
\hline
\end{tabular}

The results for the Perrin and Duplex processes are quite similar, as the only difference between the two was in the amount of $\mathrm{Cr}_{2} \mathrm{O}_{3}$ (expressed as $\mathrm{CrO}$ ) remaining in the slag. The consumption of raw materials for both processes compares well with the data from literature (Table 10).

Although the specific energy requirement (SER) was not quoted in any of the sources, it can be estimated from the total energy requirement quoted in the literature. Assuming a thermal efficiency of 60 to $75 \%$, which is reasonable for a small, open furnace operating with an open arc, the SER can range between 1920 and $2665 \mathrm{kWh} / \mathrm{t} \mathrm{LC} \mathrm{FeCr}$, which compares well with the results from the models.

The adiabatic product temperature during cocktailing was determined by iteratively changing the temperature to produce a zero energy balance. The resulting product temperatures were 2330 and $2284^{\circ} \mathrm{C}$ for the Perrin and Duplex processes respectively. 


\subsubsection{Furnace Method}

The presence of $\mathrm{SiO}_{2}$ in the slag for the Furnace Method results in slag with completely different properties to that of the Mixing Method. Due to the limited application of the Furnace Method, the required slag composition was unknown. To determine the most appropriate slag, the aspects that restrict the operating range needs to be considered. The alloy composition determines the liquidus temperature of the alloy, which limits the minimum operating temperature. This, in turn, limits the slag liquidus temperature and therefore the slag chemistry. The liquidus temperature of a $70 \% \mathrm{Cr}$ LCFeCr product is approximately $1700^{\circ} \mathrm{C}$, assuming that other elements in minor quantities will lower the liquidus temperature from that indicated in Figure 2.

As mentioned, a slag superheat of between 50 and 200 degrees Celsius (Kennedy, 2012) is generally required to achieve a balance between maintaining slag fluidity and refractory protection. The operating temperature should therefore be in the region of $1750^{\circ} \mathrm{C}$. In order to maximise the contact between alloy and slag, the furnace should have a large surface area and a shallow bath. This would cause the alloy and slag temperatures to be similar. The slag liquidus temperature should therefore be between 1550 and $1700^{\circ} \mathrm{C}$. Not many, if any, refractory systems are rated to withstand temperatures above $1800^{\circ} \mathrm{C}$. Operating at a process temperature of $1750^{\circ} \mathrm{C}$ will ensure that the alloy is molten, without operating too close to the refractory temperature limit of $1800^{\circ} \mathrm{C}$.

The slag has a natural basicity (no fluxing material added to modify slag properties) of 0.45 . This corresponds to a slag liquidus temperature of approximately $1410^{\circ} \mathrm{C}$ (Figure 14), which is much lower than the required slag liquidus temperature range of 1550 to $1700^{\circ} \mathrm{C}$. The slag composition in Figure 14 is nearly on the $\mathrm{MgO}-\mathrm{SiO}_{2}$ line, as there is very little $\mathrm{CaO}$ in the ore. The point was plotted on the $\mathrm{Al}_{2} \mathrm{O}_{3}-\mathrm{CaO}-\mathrm{MgO}$ $\mathrm{SiO}_{2}$ quaternary phase diagram, instead of the $\mathrm{Al}_{2} \mathrm{O}_{3}-\mathrm{MgO}-\mathrm{SiO}_{2}$ ternary diagram to allow for a better comparison with lime fluxed slag (Figure 15). 


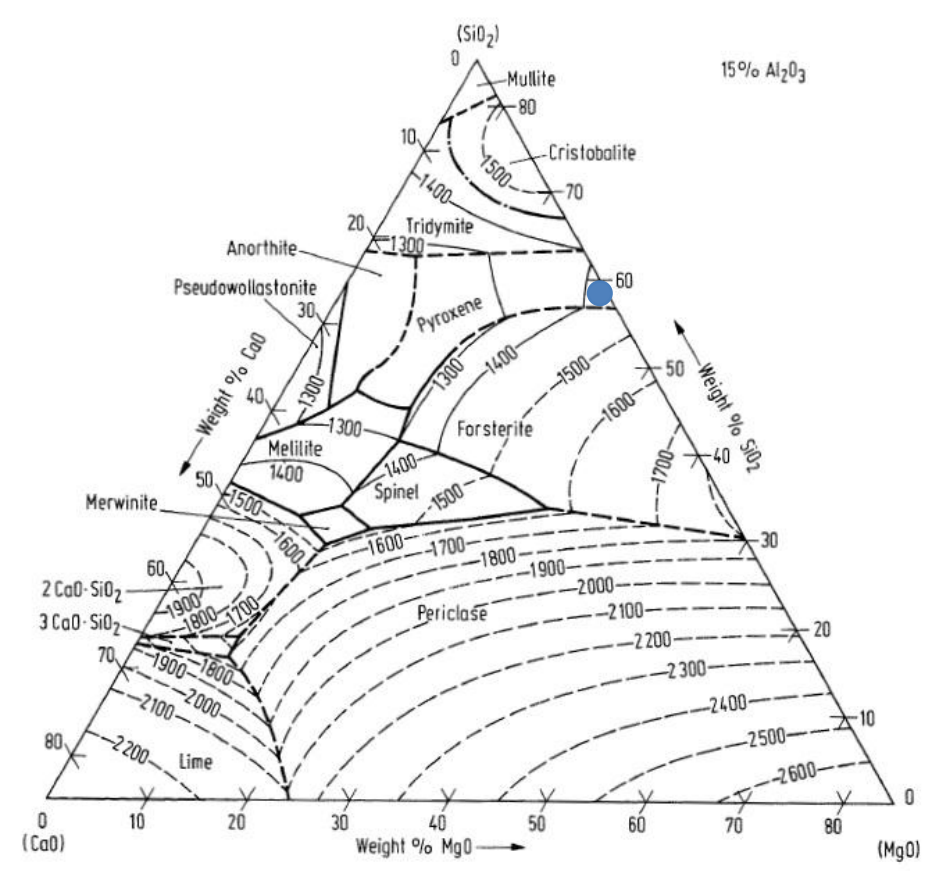

Figure 14: $\mathrm{Al}_{2} \mathrm{O}_{3}-\mathrm{CaO}-\mathrm{MgO}-\mathrm{SiO}_{2}$ quaternary phase diagram $\left(15 \% \mathrm{Al}_{2} \mathrm{O}_{3}\right)$.

(Slag Atlas, 2008)

The effect that the addition of lime has on the slag liquidus temperature is illustrated in Figure 15. As the lime addition is increased, the $\mathrm{Al}_{2} \mathrm{O}_{3}$ content decreases, because there is very little $\mathrm{Al}_{2} \mathrm{O}_{3}$ in the lime. Adding lime therefore dilutes the $\mathrm{Al}_{2} \mathrm{O}_{3}$ in the slag. For each slag basicity evaluated, the compositions were normalised for $\mathrm{Al}_{2} \mathrm{O}_{3}$ contents of 5 or $10 \%$, whichever was closer to the calculated $\mathrm{Al}_{2} \mathrm{O}_{3}$ content. With an increase in the lime addition, the system therefore moves from the $10 \%$ to the $5 \%$ $\mathrm{Al}_{2} \mathrm{O}_{3}$ diagram. 

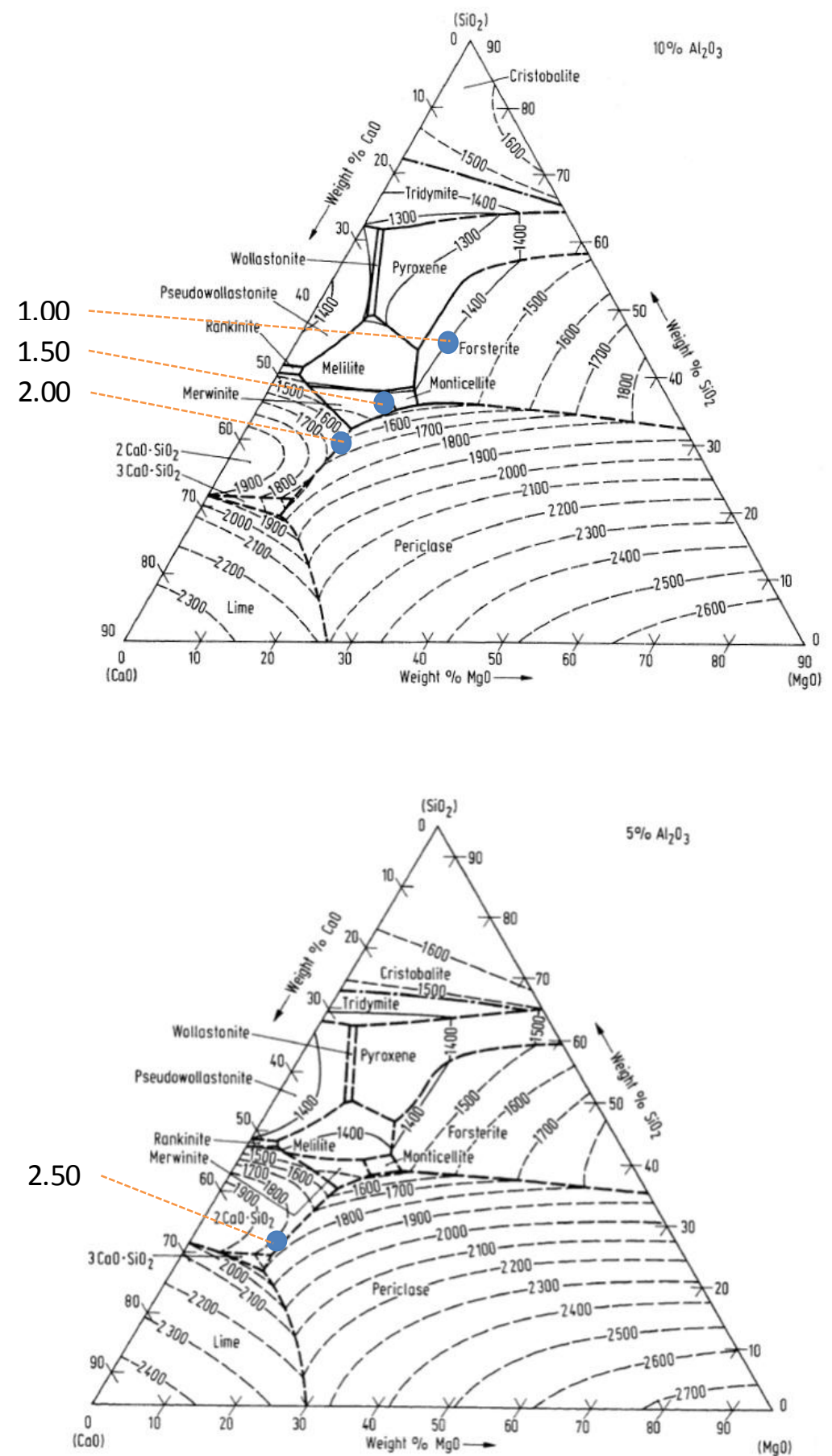

Figure 15: $\mathrm{Al}_{2} \mathrm{O}_{3}-\mathrm{CaO}-\mathrm{MgO}-\mathrm{SiO}_{2}$ quaternary phase diagrams (10\% and 5\% $\mathrm{Al}_{2} \mathrm{O}_{3}$ ).

(Slag Atlas (2008), with slag basicities indicated)

By plotting the slag liquidus temperature (read from Figure 15) against the corresponding slag basicity, the slag basicity range that matches the required slag liquidus temperature range can be determined (by interpolation). In this case, the slag basicity range is 1.66 to 2.28 for slag liquidus temperature of between 1550 and

\section{Page 30}


$1700^{\circ} \mathrm{C}$. The preference would be to operate at a lower basicity, as this would require a smaller lime addition and likely a lower specific energy for smelting. A target basicity of 1.7 was therefore used for the mass and energy balance.

As the Furnace Method does not make use of cocktailing, the additional momentum imparted by the pouring action is lost. The reaction kinetics is therefore expected to be slower than for the Mixing Method, and the $\% \mathrm{Cr}_{2} \mathrm{O}_{3}$ (or $\mathrm{CrO}$ ) in the slag is expected to be higher. $\mathrm{A} \% \mathrm{Cr}_{2} \mathrm{O}_{3}$ equivalent of $5 \%$ was chosen for the modelling. However, to improve chromium recovery, one or two cocktailing steps will likely be performed after tapping. It is expected that the resulting slag will have a $\mathrm{Cr}_{2} \mathrm{O}_{3}$ content similar to that of the Duplex process ( $3 \%)$. The energy consumption was therefore calculated based on the $5 \% \mathrm{Cr}_{2} \mathrm{O}_{3}$ in the slag, as the reactions only take place up to this point in the furnace. However, the specific raw material consumptions and specific energy requirement were calculated by using a $3 \% \mathrm{Cr}_{2} \mathrm{O}_{3}$ slag, as the unit consumptions would be lower for a higher recovery rate.

The assumptions made in developing the mass and energy balances for the Furnace Method processes are listed and discussed in Table 11.

Table 11: Assumptions for Furnace Method mass and energy balances.

\begin{tabular}{|l|l|}
\hline Assumption & Reason \\
\hline $\begin{array}{l}\text { The slag } \mathrm{Cr}_{2} \mathrm{O}_{3} \text { content } \\
\text { was } 5 \% .\end{array}$ & $\begin{array}{l}\text { The bath is expected to be less turbulent in the Furnace } \\
\text { Method, compared to the cocktailing in the Mixing } \\
\text { Method. }\end{array}$ \\
\hline $\begin{array}{l}\text { The temperature of the } \\
\text { seSiCr in the LFFM was }\end{array}$ & $\begin{array}{l}\text { Some energy will be lost during the deslagging and } \\
\text { transfer of the FeSiCr to the LC FeCr furnace. Although } \\
\text { the energy loss was not calculated, the temperature } \\
\text { was found not to impact the overall energy balance } \\
\text { significantly, provided that the FeSiCr was fed in the } \\
\text { molten state. }\end{array}$ \\
\hline
\end{tabular}

The inputs and outputs for the Furnace Method processes are shown in Figure 16. The modelling results for the Solid Feed Furnace Method and Liquid Feed Furnace Method are shown in Tables 9 and 10 respectively. Note that the inputs and outputs are for $5 \% \mathrm{Cr}_{2} \mathrm{O}_{3}$ equivalent in the slag. The unit consumption values are quoted for both the $5 \%$ (no cocktailing) and $3 \%$ (with cocktailing) $\mathrm{Cr}_{2} \mathrm{O}_{3}$ scenarios, as the latter were used in the cost calculations. 


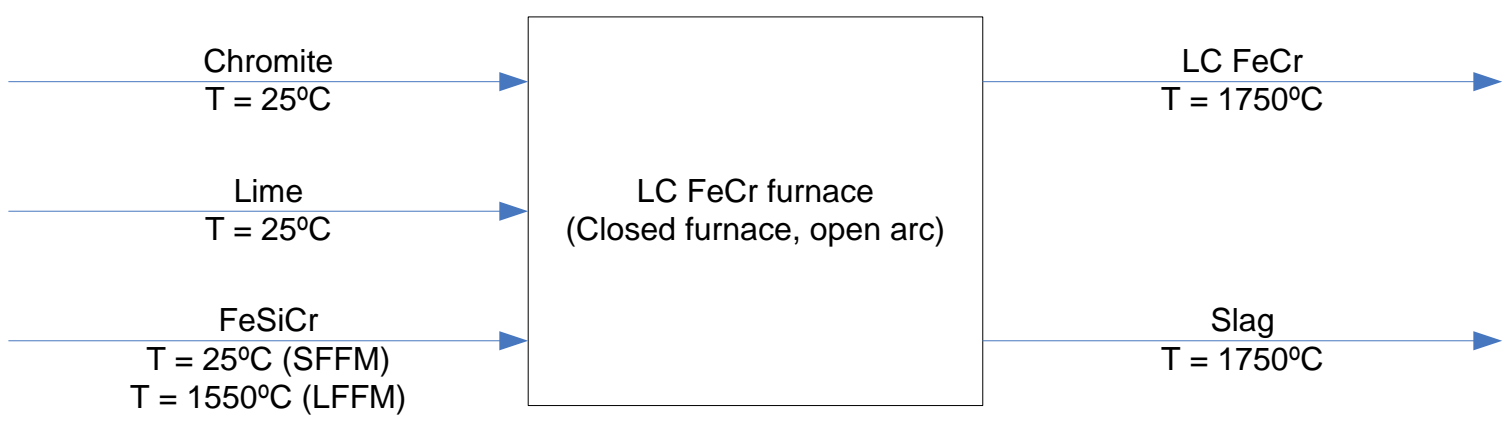

Figure 16: Inputs and outputs to the LC FeCr production process (Furnace Method).

Table 12: Solid Feed Furnace Method mass and energy balance.

(HSC Chemistry 7.1)

\begin{tabular}{|l|r|r|r|r|}
\hline Chromite & \multicolumn{1}{|c|}{ wt \% } & \multicolumn{1}{|c|}{ kg } & kmol & kWh \\
\hline Total & $\mathbf{1 0 0 . 0 0 \%}$ & $\mathbf{1 6 0 1}$ & & $-\mathbf{4 4 7 6}$ \\
\hline $\mathrm{Al} 2 \mathrm{O} 3$ & $10.89 \%$ & 174 & 2 & -796 \\
\hline $\mathrm{CaO}$ & $0.36 \%$ & 6 & 0 & -18 \\
\hline $\mathrm{Cr} 2 \mathrm{O} 3$ & $48.71 \%$ & 780 & 5 & -1625 \\
\hline $\mathrm{Fe} 2 \mathrm{O} 3$ & $14.50 \%$ & 232 & 1 & -334 \\
\hline $\mathrm{MgO}$ & $18.52 \%$ & 297 & 7 & -1230 \\
\hline $\mathrm{SiO} 2$ & $7.02 \%$ & 112 & 2 & -473 \\
\hline
\end{tabular}

\begin{tabular}{|l|r|r|r|r|}
\hline Metal & \multicolumn{1}{|c|}{ wt \% } & \multicolumn{1}{c|}{ kg } & \multicolumn{1}{c|}{ kmol } & \multicolumn{1}{c|}{ kWh } \\
\hline Total & $\mathbf{1 0 0 . 0 0 \%}$ & $\mathbf{1 0 0 0}$ & & $\mathbf{4 6 3}$ \\
\hline $\mathrm{Cr}(\mathrm{l})$ & $\mathbf{7 2 . 0 0 \%}$ & $\mathbf{7 2 0}$ & 13.847 & 340 \\
\hline $\mathrm{Fe}(\mathrm{I})$ & $26.50 \%$ & $\mathbf{2 6 5}$ & 4.745 & 108 \\
\hline $\mathrm{Si}(\mathrm{I})$ & $\mathbf{1 . 5 0} \%$ & $\mathbf{1 5}$ & 0.534 & 14 \\
\hline
\end{tabular}

\begin{tabular}{|l|r|r|r|r|}
\hline Lime & \multicolumn{1}{|c|}{ wt $\%$} & $\mathbf{k g}$ & kmol & \multicolumn{1}{c|}{ kWh } \\
\hline Total & $\mathbf{1 0 0 . 0 0 \%}$ & $\mathbf{8 3 6}$ & & $\mathbf{- 2 6 4 5}$ \\
\hline $\mathrm{Al} 2 \mathrm{O} 3$ & $0.00 \%$ & 0 & 0 & 0 \\
\hline $\mathrm{CaO}$ & $96.33 \%$ & 805 & 14 & -2532 \\
\hline $\mathrm{Cr} 2 \mathrm{O} 3$ & $0.00 \%$ & 0 & 0 & 0 \\
\hline $\mathrm{FeO}$ & $0.00 \%$ & 0 & 0 & 0 \\
\hline $\mathrm{MgO}$ & $0.90 \%$ & 8 & 0 & -31 \\
\hline $\mathrm{SiO} 2$ & $0.50 \%$ & 4 & 0 & -18 \\
\hline $\mathrm{CaCO} 3$ & $2.27 \%$ & 19 & 0 & -64 \\
\hline
\end{tabular}

\begin{tabular}{|l|r|r|r|r|}
\hline FeSiCr & \multicolumn{1}{|c|}{ wt \% } & \multicolumn{1}{|c|}{ kg } & \multicolumn{1}{c|}{ kmol } & \multicolumn{1}{|c|}{ kWh } \\
\hline Total & $\mathbf{1 0 0 . 0 0 \%}$ & $\mathbf{6 4 3}$ & & $\mathbf{0}$ \\
\hline $\mathrm{Cr}$ & $40.00 \%$ & 257 & 4.946 & 0 \\
\hline $\mathrm{Fe}$ & $18.00 \%$ & 116 & 2.072 & 0 \\
\hline $\mathrm{Si}$ & $42.00 \%$ & 270 & 9.614 & 0 \\
\hline
\end{tabular}

\begin{tabular}{|l|r|r|r|r|}
\hline Slag & wt \% & \multicolumn{1}{c|}{ kg } & kmol & kWh \\
\hline Total & $\mathbf{1 0 0 . 0 0 \%}$ & $\mathbf{2 0 7 2}$ & & -5930 \\
\hline $\mathrm{Al2O}(\mathrm{I})$ & $8.42 \%$ & 174 & 1.710 & -639 \\
\hline $\mathrm{CaO}(\mathrm{I})$ & $39.65 \%$ & 822 & 14.650 & -1891 \\
\hline $\mathrm{Cr} 2 \mathrm{O} 3(\mathrm{I})$ & $0.00 \%$ & 0 & 0.000 & 0 \\
\hline $\mathrm{CrO}(\mathrm{I})$ & $4.47 \%$ & 93 & 1.363 & -70 \\
\hline $\mathrm{FeO}(\mathrm{I})$ & $0.82 \%$ & 17 & 0.235 & -9 \\
\hline $\mathrm{Fe} 2 \mathrm{O} 3(\mathrm{I})$ & $0.00 \%$ & 0 & 0.000 & 0 \\
\hline $\mathrm{MgO}(\mathrm{I})$ & $14.68 \%$ & 304 & 7.545 & -934 \\
\hline $\mathrm{SiO} 2(\mathrm{I})$ & $31.96 \%$ & 662 & 11.021 & -2387 \\
\hline
\end{tabular}

\begin{tabular}{|c|c|c|c|c|}
\hline Off-gas & wt \% & kg & kmol & kWh \\
\hline Total & $100.00 \%$ & 8 & & -16 \\
\hline $\mathrm{CO} 2(\mathrm{~g})$ & $100.00 \%$ & 8 & 0.190 & -16 \\
\hline
\end{tabular}

Consumptions

\begin{tabular}{|c|c|c|c|}
\hline & & No cocktailing & With cocktailing \\
\hline Chromite & $\mathrm{kg} / \mathrm{t} \mathrm{LC} \mathrm{FeCr}$ & 1601 & 1520 \\
\hline Lime & $\mathrm{kg} / \mathrm{t} \mathrm{LC} \mathrm{FeCr}$ & 836 & 829 \\
\hline $\mathrm{FeSiCr}$ & $\mathrm{kg} / \mathrm{t} \mathrm{LC} \mathrm{FeCr}$ & 643 & 635 \\
\hline Energy (SER) & $\mathrm{kWh} / \mathrm{t} \mathrm{LC} \mathrm{FeCr}$ & 1638 & 1589 \\
\hline
\end{tabular}


Table 13: Liquid Feed Furnace Method mass and energy balance.

(HSC Chemistry 7.1)

\begin{tabular}{|l|r|r|r|r|}
\hline Chromite & \multicolumn{1}{|c|}{ wt \% } & \multicolumn{1}{|c|}{ kg } & kmol & kWh \\
\hline Total & $\mathbf{1 0 0 . 0 0 \%}$ & $\mathbf{1 6 0 1}$ & & $\mathbf{- 4 4 7 6}$ \\
\hline $\mathrm{Al} 2 \mathrm{O} 3$ & $10.89 \%$ & 174 & 2 & -796 \\
\hline $\mathrm{CaO}$ & $0.36 \%$ & 6 & 0 & -18 \\
\hline $\mathrm{Cr} 2 \mathrm{O} 3$ & $48.71 \%$ & 780 & 5 & -1625 \\
\hline $\mathrm{Fe} 2 \mathrm{O} 3$ & $14.50 \%$ & 232 & 1 & -334 \\
\hline $\mathrm{MgO}$ & $18.52 \%$ & 297 & 7 & -1230 \\
\hline $\mathrm{SiO} 2$ & $7.02 \%$ & 112 & 2 & -473 \\
\hline
\end{tabular}

\begin{tabular}{|l|r|r|r|r|}
\hline Metal & \multicolumn{1}{|c|}{ wt \% } & \multicolumn{1}{c|}{ kg } & kmol & \multicolumn{1}{c|}{ kWh } \\
\hline Total & $\mathbf{1 0 0 . 0 0 \%}$ & $\mathbf{1 0 0 0}$ & & $\mathbf{4 6 3}$ \\
\hline $\mathrm{Cr}(\mathrm{I})$ & $\mathbf{7 2 . 0 0 \%}$ & $\mathbf{7 2 0}$ & 13.847 & 340 \\
\hline $\mathrm{Fe}(\mathrm{I})$ & $\mathbf{2 6 . 5 0 \%}$ & $\mathbf{2 6 5}$ & 4.745 & 108 \\
\hline $\mathrm{Si}(\mathrm{I})$ & $\mathbf{1 . 5 0 \%}$ & $\mathbf{1 5}$ & 0.534 & 14 \\
\hline
\end{tabular}

\begin{tabular}{|l|r|r|r|r|}
\hline Lime & \multicolumn{1}{|c|}{ wt \% } & kg & kmol & \multicolumn{1}{c|}{ kWh } \\
\hline Total & $\mathbf{1 0 0 . 0 0 \%}$ & $\mathbf{8 3 6}$ & & $\mathbf{- 2 6 4 5}$ \\
\hline $\mathrm{Al} 2 \mathrm{O} 3$ & $0.00 \%$ & 0 & 0 & 0 \\
\hline $\mathrm{CaO}$ & $96.33 \%$ & 805 & 14 & -2532 \\
\hline $\mathrm{Cr} 2 \mathrm{O} 3$ & $0.00 \%$ & 0 & 0 & 0 \\
\hline $\mathrm{FeO}$ & $0.00 \%$ & 0 & 0 & 0 \\
\hline $\mathrm{MgO}$ & $0.90 \%$ & 8 & 0 & -31 \\
\hline $\mathrm{SiO} 2$ & $0.50 \%$ & 4 & 0 & -18 \\
\hline $\mathrm{CaCO} 3$ & $2.27 \%$ & 19 & 0 & -64 \\
\hline
\end{tabular}

\begin{tabular}{|l|r|r|r|r|}
\hline FeSiCr & \multicolumn{1}{|c|}{ wt \% } & \multicolumn{1}{|c|}{ kg } & \multicolumn{1}{c|}{ kmol } & \multicolumn{1}{c|}{ kWh } \\
\hline Total & $\mathbf{1 0 0 . 0 0 \%}$ & $\mathbf{6 4 3}$ & & $\mathbf{3 9 9}$ \\
\hline $\mathrm{Cr}(\mathrm{I})$ & $40.00 \%$ & 257 & 4.946 & 111 \\
\hline $\mathrm{Fe}(\mathrm{I})$ & $18.00 \%$ & 116 & 2.072 & 43 \\
\hline $\mathrm{Si}(\mathrm{I})$ & $42.00 \%$ & 270 & 9.614 & 245 \\
\hline
\end{tabular}

\begin{tabular}{|l|r|r|r|r|}
\hline Slag & wt \% & \multicolumn{1}{c|}{ kg } & kmol & \multicolumn{1}{c|}{ kWh } \\
\hline Total & $\mathbf{1 0 0 . 0 0 \%}$ & $\mathbf{2 0 7 2}$ & & $-\mathbf{5 9 3 0}$ \\
\hline $\mathrm{Al} 2 \mathrm{O} 3(\mathrm{I})$ & $8.42 \%$ & 174 & 1.710 & -639 \\
\hline $\mathrm{CaO}(\mathrm{I})$ & $39.65 \%$ & 822 & 14.650 & -1891 \\
\hline $\mathrm{Cr} 2 \mathrm{O} 3(\mathrm{I})$ & $0.00 \%$ & 0 & 0.000 & 0 \\
\hline $\mathrm{CrO}(\mathrm{I})$ & $4.47 \%$ & 93 & 1.363 & -70 \\
\hline $\mathrm{FeO}(\mathrm{I})$ & $0.82 \%$ & 17 & 0.235 & -9 \\
\hline $\mathrm{Fe} 2 \mathrm{O} 3(\mathrm{I})$ & $0.00 \%$ & 0 & 0.000 & 0 \\
\hline $\mathrm{MgO}(\mathrm{I})$ & $14.68 \%$ & 304 & 7.545 & -934 \\
\hline $\mathrm{SiO} 2(\mathrm{I})$ & $31.96 \%$ & 662 & 11.021 & -2387 \\
\hline
\end{tabular}

\begin{tabular}{|c|c|c|c|c|}
\hline Off-gas & wt \% & kg & kmol & kWh \\
\hline Total & $100.00 \%$ & 8 & & -16 \\
\hline $\mathrm{CO} 2(\mathrm{~g})$ & $100.00 \%$ & 8 & 0.190 & -16 \\
\hline
\end{tabular}

Consumptions

\begin{tabular}{|c|c|c|c|}
\hline & & No cocktailing & With cocktailing \\
\hline Chromite & $\mathrm{kg} / \mathrm{t} \mathrm{LC} \mathrm{FeCr}$ & 1601 & 1520 \\
\hline Lime & $\mathrm{kg} / \mathrm{t} \mathrm{LC} \mathrm{FeCr}$ & 836 & 829 \\
\hline $\mathrm{FeSiCr}$ & $\mathrm{kg} / \mathrm{t} \mathrm{LC} \mathrm{FeCr}$ & 643 & 635 \\
\hline Energy (SER) & $\mathrm{kWh} / \mathrm{t} \mathrm{LC} \mathrm{FeCr}$ & 1238 & 1202 \\
\hline
\end{tabular}

Due to the limited use of the Furnace Method, little to no data was available in the literature to compare the modelling results with. However, as the same modelling methodology was followed as for the Mixing Method, as well as the fact that the chromite and FeSiCr consumptions were similar to that of the Mixing Method, the likelihood of significant errors was considered to be low.

The results from the mass and energy balances showed that the lime addition was significantly lower ( 33\%) for the Furnace Method than for the Mixing Method. This is not unexpected, as the final slag basicity was also proportionately lower. Even more significant was the saving in energy requirement, with the SFFM and LFFM requiring respectively 29 and $47 \%$ less energy than the Mixing Method.

\subsubsection{Raw Materials}

After determining the specific consumption for each of the raw materials from the mass and energy balances, the raw material costs per tonne of $\mathrm{LC} \mathrm{FeCr}$ could be 
calculated by multiplying the consumption with the unit cost for each material. The unit prices are listed in Table 14 and the unit consumptions and costs in Table 15. Note that the consumptions include that for the production of FeSiCr. Due to the variability of the prices, the averages between the low and high raw material costs were used.

Table 14: Raw material unit costs.

\begin{tabular}{|l|c|c|l|}
\hline \multirow{2}{*}{ Item } & \multicolumn{3}{|c|}{ Price (USD / tonne) } \\
\cline { 2 - 4 } & Low & High & Source \\
\hline Ore & 205 & 212 & Metalbulletin.com \\
\hline Coke & 202 & 209 & Steelonthenet.com \\
\hline Quartz & 50 & 100 & Operating plant data \\
\hline Lime & 50 & 100 & Operating plant data \\
\hline
\end{tabular}

Table 15: Raw material consumption and cost for all process options.

\begin{tabular}{|c|c|c|c|c|c|c|}
\hline & & Process & Ore & Coke & Quartz & Lime \\
\hline \multirow{4}{*}{ 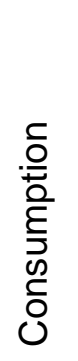 } & \multirow{4}{*}{ 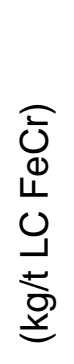 } & Perrin & 2261 & 443 & 886 & 1216 \\
\hline & & Duplex & 2315 & 447 & 893 & 1255 \\
\hline & & SFFM & 2287 & 445 & 889 & 829 \\
\hline & & LFFM & 2287 & 445 & 889 & 829 \\
\hline \multirow{4}{*}{\multicolumn{2}{|c|}{ 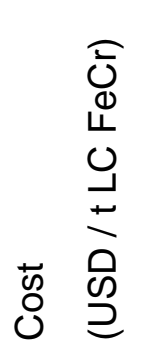 }} & Perrin & 471.49 & 91.01 & 66.43 & 91.20 \\
\hline & & Duplex & 482.68 & 91.69 & 66.98 & 94.13 \\
\hline & & SFFM & 476.88 & 91.34 & 66.68 & 62.17 \\
\hline & & LFFM & 476.88 & 91.34 & 66.68 & 62.17 \\
\hline
\end{tabular}

\subsubsection{Smelting Power}

The specific energy consumption was determined from the mass and energy balances and was compared with published data. In all instances the results from the models were similar to those found in the literature. However, no published information was available on the specific energy requirement for the $\mathrm{LC} \mathrm{FeCr}$ 
production step. The published total energy values were therefore used for the cost estimate.

The electricity tariff varies significantly between countries, regions within countries, time of year and time of day. Prices typically range between 6 and 12 United States cents per kWh for South African (Eskom, 2014) and Australian (Government of Western Australia, n.d.) industrial users. Lower electricity tariffs are available, especially in the Middle East, where prices of 3.5 United States cents per kWh are not uncommon (Saudi Arabia) (Dynamic Energy and Water Solutions, 2014).

The unit consumptions and costs are shown in Table 16.

Table 16: Smelting energy consumption and cost for all process options.

\begin{tabular}{|c|c|c|c|}
\hline Process & $\begin{array}{l}\text { Consumption } \\
\text { (kWh/t LC FeCr) }\end{array}$ & $\begin{array}{l}\text { Low cost } \\
\text { (USD / t LC FeCr) } \\
\text { @USD } 0.06 \text { / kWh }\end{array}$ & $\begin{array}{l}\text { High cost } \\
\text { (USD / t LC FeCr) } \\
\text { @USD } 0.12 \text { / kWh }\end{array}$ \\
\hline Perrin & 8143 & 488.58 & 977.15 \\
\hline Duplex & 8268 & 496.08 & 992.17 \\
\hline SFFM & 6880 & 412.77 & 825.55 \\
\hline LFFM & 6363 & 381.79 & 763.57 \\
\hline
\end{tabular}

\subsubsection{Auxiliary Power}

The auxiliary power is considered to be consumed power, not directly required for heating and smelting of the raw materials. This includes all pumps, fans, lighting, cranes, workshop machinery, instruments, control systems, etc. To calculate this accurately, a detailed equipment list with equipment sizes would be needed. This is obviously not practical for the purposes of this study. Based on detailed costing done on a number of studies and projects in the pyrometallurgical industry, it was found that the furnace power makes up between $85 \%$ and $95 \%$ of the total plant power consumption. The auxiliary power is therefore between $5 \%$ and $15 \%$, depending on the type of operation.

The lower auxiliary power percentage is associated with a high smelting power process, such as silicon metal, while the higher percentage is typical of a low smelting power process, such as platinum. The inverse relationship is due to the fact that the auxiliary power will remain relatively constant (in terms of unit operations, not throughput). The higher the smelting power is, the lower the percentage contribution of the auxiliary power would be. For a low carbon ferrochrome plant, the auxiliary 
power was assumed to be $10 \%$ of the total power requirement for the facility. The associated consumptions and costs are listed in Table 17.

Table 17: Auxiliary energy consumption and cost for all process options.

\begin{tabular}{|c|c|c|c|}
\hline Process & $\begin{array}{l}\text { Consumption } \\
\text { (kWh/t LC FeCr) }\end{array}$ & $\begin{array}{l}\text { Low cost } \\
\text { (USD / t LC FeCr) } \\
\text { @USD } 0.06 \text { / kWh }\end{array}$ & $\begin{array}{l}\text { High cost } \\
\text { (USD / t LC FeCr) } \\
\text { @USD } 0.12 \text { / kWh }\end{array}$ \\
\hline Perrin & 905 & 54.29 & 108.57 \\
\hline Duplex & 919 & 55.12 & 110.24 \\
\hline SFFM & 764 & 45.86 & 91.73 \\
\hline LFFM & 707 & 42.42 & 84.84 \\
\hline
\end{tabular}

\subsubsection{Operational Labour}

Labour is the operating cost item that probably varies the most based on the location of the facility. The labour requirements are expected to be fairly similar for all four process routes. The labour costs were split into three categories, namely administrative, maintenance and operational labour.

Administrative labour, which includes the Chief Executive Officer, administrative, human resources, information technology, marketing and security personnel are all included as part of the overhead costs (Section 3.2.7). Maintenance personnel were not included as part of the labour estimate, as it was already included as part of the maintenance costs (Section 3.2.6).

Operational labour costs were determined by estimating the manpower requirements for operating the equipment used for producing low carbon ferrochrome. This was based on operational experience. The detailed personnel list is shown in Table 45 in Appendix A.

Humphreys (2004) proposed a relationship between the plant throughput and the man-hour requirement:

$$
\frac{\text { Operating_Workhours }}{\text { tonnes_product }}=t *\left[\frac{\text { No._Processing_Steps }}{(\text { capacity }, t p d)^{0.76}}\right]
$$

In the equation, $t$ is a constant and that depends on the type of operation. The value thereof is 23 for high labour operations (typically batch operations), 17 for average labour intensity operations and 10 for operations with high levels of automated control. 
For this evaluation, a value of 23 was chosen, as the operation of a furnace plant requires significant amounts of manual labour. Five (5) processing steps where identified where materials are handled, namely raw materials handling, furnace feeding, smelting, tapping and product handling.

The throughput for this evaluation is 40000 tonnes of LC FeCr per year. However, considering a 4-shift system, each shift would produce 10000 tonnes of LC FeCr per year, or 27.4 tonnes per day.

Substituting these values in the equation yields the daily man-hour requirement of 254.5. For an average of 6 working hours per day (24 hour day, 4 shift system), the required number of operating personnel would be 170. As shown in the personnel list (Table 45 in Appendix A) the total personnel requirement is 228. However, subtracting personnel that are not directly involved in production activities (plant management, HSE, laboratory, stores and emergency services), the total contingent is 179. The personnel list is therefore appropriate for the evaluation.

The personnel were classified into seven salary bands. The average salary was estimated from salary review data for South Africa (average labour cost) and Australia (high labour cost). Although Australia does not possess any significant chromite ore reserves, it was selected to indicate the effect that the labour cost has on the overall operating expenditure. The data was sourced from an online salary survey website (PayScale Inc., 2015).

The salary data is shown in Table 18. In each instance, the maximum salary is quoted, except for Levels $E$ and $F$ (Operators and Senior Operators), where the median salary was assigned for operators and the maximum salary for senior operators. All currencies were converted to United States Dollars.

Table 18: Salary data for South Africa and Australia (USD) (PayScale Inc., 2015).

\begin{tabular}{|c|l|r|r|}
\hline Grade & Description & South Africa & Australia \\
\hline A & Chief Executive Officer & 224106 & 301935 \\
\hline B & Chief Operating Officer & 159819 & 222801 \\
\hline C & Unit Manager & 86341 & 152516 \\
\hline D & Production Foreman & 35722 & 83560 \\
\hline E & Senior Operator & 17190 & 73824 \\
\hline F & Operator & 10135 & 57908 \\
\hline G & Labourer & 5574 & 38645 \\
\hline
\end{tabular}


Using the personnel list in Table 45 and the rates from Table 18, the operating labour cost per tonne of LC FeCr were calculated to be:

Country with average labour cost (South Africa) = USD 98.65

Country with high labour cost (Australia) = USD 416.05

\subsubsection{Maintenance}

When designing a plant, the cost for maintenance can be described as a percentage of the depreciable capital investment (Humphreys, 2004). This is a sensible way of doing it, because as the number, size and complexity of equipment increases, the cost to maintain it can also be expected to increase proportionally. This percentage was estimated to range between 3 and 5\% (Humphreys, 2004).

Based on the experience of the author, the investment cost for a new plant that is able to produce $40 \mathrm{ktpa}$ of low carbon ferrochrome can be between $\$ 150,000,000$ and $\$ 200,000,000$. Of this, approximately $30 \%$ would be for equipment, with the remainder being for property, civil and structural, engineering and design, etc. Between $\$ 45,000,000$ and $\$ 60,000,000$ could therefore be considered to be depreciable capital. Using the highest percentage (5\%) and capital cost $(\$ 60,000,000$ depreciable capital), the maintenance cost would be approximately $\$ 75$ per tonne of low carbon ferrochrome. This price includes the labour and supervision cost for maintenance.

\subsubsection{Overheads}

Most of the overheads cost items have been excluded (see Section 3.2.8) from these calculations. The number of personnel that do not directly contribute to the operation and maintenance of the plant has been estimated. The administrative and other personnel list is shown in Table 46.

All personnel were again classified into seven broad salary bands, as was done in the operational labour estimate. The rates specified in Table 18 were again used and the calculated administrative cost per tonne of LC FeCr was calculated to be:

Country with average labour cost (South Africa) = USD 39.54

Country with high labour cost (Australia) $=$ USD 133.59

\subsubsection{Exclusions}

Some items were not considered in the evaluation of the operating expenditure. They are discussed here, along with the reasons for their omission.

Delivery of raw materials was excluded, as it was assumed that the fictional facility would be constructed close to the source of the raw materials. In any event, the delivery cost would be highly dependent on the location of the plant, the location of the raw material source and the distance between the two. It could therefore not be reasonably included in this evaluation. 
Financing costs can vary significantly between projects, depending on the amount that needs to be financed (if any), the borrower's credit history and the project feasibility as a whole. The financing cost does not impact the profitability of the project directly and was therefore excluded.

Taxes have been excluded due to their variability between countries and regions.

Depreciation does not affect the cash flow of the facility, except in so far as it lowers the amount of tax that the company would need to pay.

Other consumables, such as electrodes, casings, tap hole clay, drill bits, etc. have been excluded, as they generally contribute very little to the operating costs.

\subsubsection{Summary of Operating Costs}

The operating cost components for all four process options were quantified. The total operating costs for the processes are shown in Table 19.

Table 19: Operating cost range for LC FeCr production.

\begin{tabular}{|l|c|c|}
\hline Process & $\begin{array}{c}\text { Minimum operating cost } \\
\text { (USD/t LC FeCr) }\end{array}$ & $\begin{array}{c}\text { Maximum operating cost } \\
\text { (USD/t LC FeCr) }\end{array}$ \\
\hline Perrin & 1476 & 2430 \\
\hline Duplex & 1500 & 2463 \\
\hline SFFM & 1369 & 2239 \\
\hline LFFM & 1334 & 2170 \\
\hline
\end{tabular}

The ore, coke, quartz, operational labour, maintenance and overhead costs varied by less than $3 \%$ between the processes and were therefore not deemed to be significant in a comparison between the processes. Combined, these items made up between 51.4 and $63.6 \%$ of the total operating cost.

The remaining 36.4 to $48.6 \%$ was made up of the smelting power (and auxiliary power) and the lime, which showed a decrease of $23 \%$ and $34 \%$ respectively from the highest cost process (Duplex process) and the lowest cost process (LFFM). The overall saving in operating cost when selecting the LFFM instead of the Perrin process would be between 9.6 and $10.7 \%$. This value is even higher when compared to the Duplex process.

The relative power costs for the four processes, as well as the total operating costs are shown in Figure 17. 


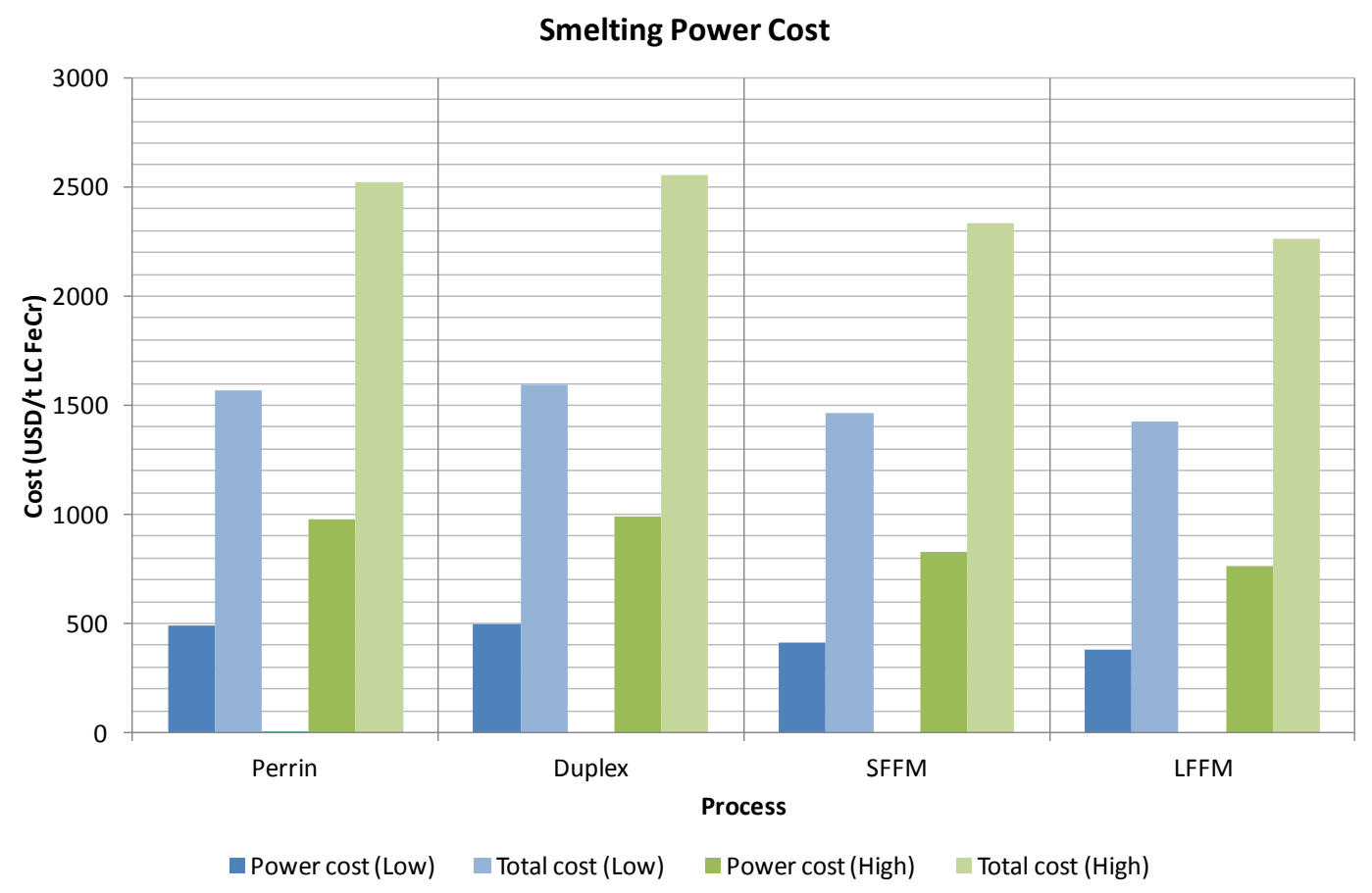

Figure 17: Power and total operating cost.

The comparative lime cost for the four processes are shown in Figure 18. The total operating costs have not been included in the figure, as the lime only constitutes between 2.8 and $6.3 \%$ of the total operating cost. A saving in the lime cost would therefore not drive the decision when selecting which process route to follow, but would be an additional bonus.

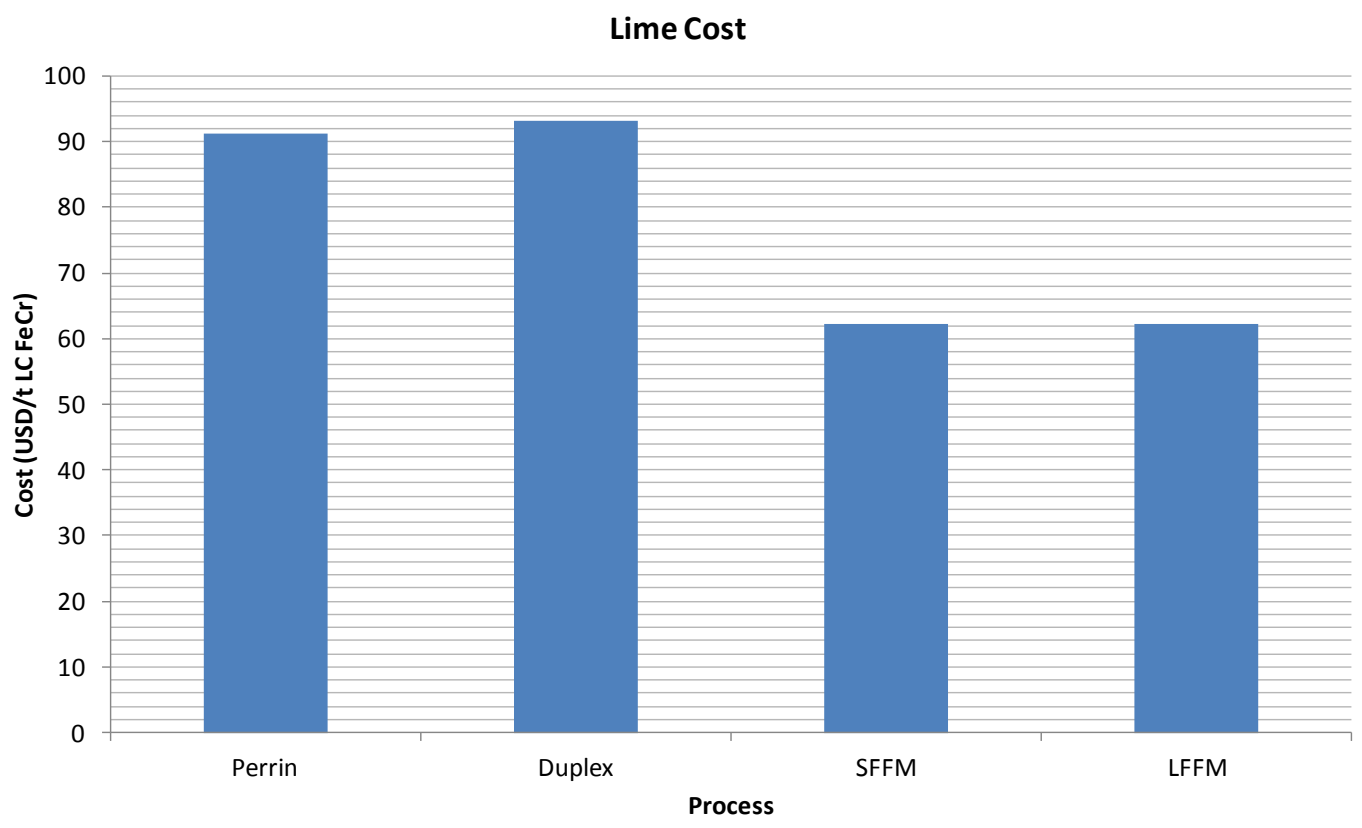

Figure 18: Lime cost.

Page 40

(C) University of Pretoria 


\subsection{Hexavalent Chromium}

An additional point to consider when comparing the different process routes is that of hexavalent chromium. Although the health and safety and environmental aspects have not been addressed in any great detail in this work, the impact that the handling of $\mathrm{Cr}(\mathrm{VI})$ has on the project economics is worth noting.

\subsection{1 $\mathrm{Cr}(\mathrm{VI})$ Legislation}

$\mathrm{Cr}(\mathrm{VI})$ is severely toxic to humans, causing cancer and ulcers, as described by Langård and Costa (2007). The emission limits to water and air are therefore very strict.

The limit for $\mathrm{Cr}(\mathrm{VI})$ exposure over an 8 hour period (weighted average) for airborne particles, is $5.0 \times 10^{-6} \mathrm{mg} / \mathrm{l}$ (Occupational Safety and Health Administration, 2014). The allowable concentration in water for effluent discharge varies by country, but is generally less than $0.5 \mathrm{mg} / \mathrm{l}$ ( $0.02 \mathrm{mg} / \mathrm{l}$ for South Africa)(Mulange \& Garbers-Craig, 2012). $\mathrm{Cr}(\mathrm{VI})$ is extremely soluble in water, having a solubility of $790 \mathrm{~g} / \mathrm{l}$ and $624 \mathrm{~g} / \mathrm{l}$ for $\mathrm{K}_{2} \mathrm{CrO}_{4}$ and $\mathrm{CrO}_{3}$, respectively (World Health Organization, 2004).

\subsection{2 $\mathrm{Cr}(\mathrm{VI})$ Formation}

There are several factors that affect the formation of $\mathrm{Cr}(\mathrm{VI})$. The most significant of these are the availability of oxygen (which oxidises $\operatorname{Cr}(\mathrm{III})$ ), the presence of alkaline compounds (which form $\mathrm{Cr}(\mathrm{VI})$-bearing compounds), the presence of fine ore (which passes to the off-gas and doesn't get taken up in the slag) and temperature (Beukes, et al., 2010). An open furnace and a basic slag would therefore be more conducive to the formation of $\mathrm{Cr}(\mathrm{VI})$.

Dust from a smelting operation originates from three sources, namely vaporisation of elements and their subsequent oxidation and reaction, splashing of slag and alloy due to turbulence in the bath and gas formation, as well as dust carry-over from the raw material feed (short-circuiting) (Ma \& Garbers-Craig, 2006). Raw material carryover and splashing typically result in a coarse dust particle, while fuming produces fine particles.

\subsection{3 $\mathrm{Cr}(\mathrm{VI})$ Treatment and Disposal}

$\mathrm{Cr}(\mathrm{VI})$ is very leachable, which poses a risk to ground water contamination when the dust is stockpiled and becomes wet (Ma \& Garbers-Craig, 2006). Therefore, even if proper dust capturing limits the $\mathrm{Cr}(\mathrm{VI})$ content in the vicinity of the furnace, the disposal of the dust still requires attention.

Although wet scrubbers may be more efficient in that the dust capturing and water contacting steps are combined, their use is usually limited to applications where carbon monoxide rich off-gas can be captured and used for heating purposes elsewhere. As this is not the case in the production of low carbon ferrochrome, the discussions will be centred on dust capturing with a bag house. The use of wet scrubbers is even less prevalent in low rainfall areas. 
There are several methods in which $\mathrm{Cr}(\mathrm{VI})$ can be treated. The purpose of this study is not to provide an in depth review of the available methods, but rather to indicate the extent of the impact that the treatment of $\mathrm{Cr}(\mathrm{VI})$ has on the profitability of an operation. A common method of disposing of $\mathrm{Cr}(\mathrm{VI})$ containing waste, particularly in a South African context, is that of reducing it in an aqueous state, followed by precipitation of $\mathrm{Cr}(\mathrm{III})$ hydroxide. The precipitate then needs to be removed from the water by filtration before being disposed of in a designated landfill site (Beukes, et al., 2012). The steps in the treatment of $\mathrm{Cr}(\mathrm{VI})$ are illustrated in Figure 19.

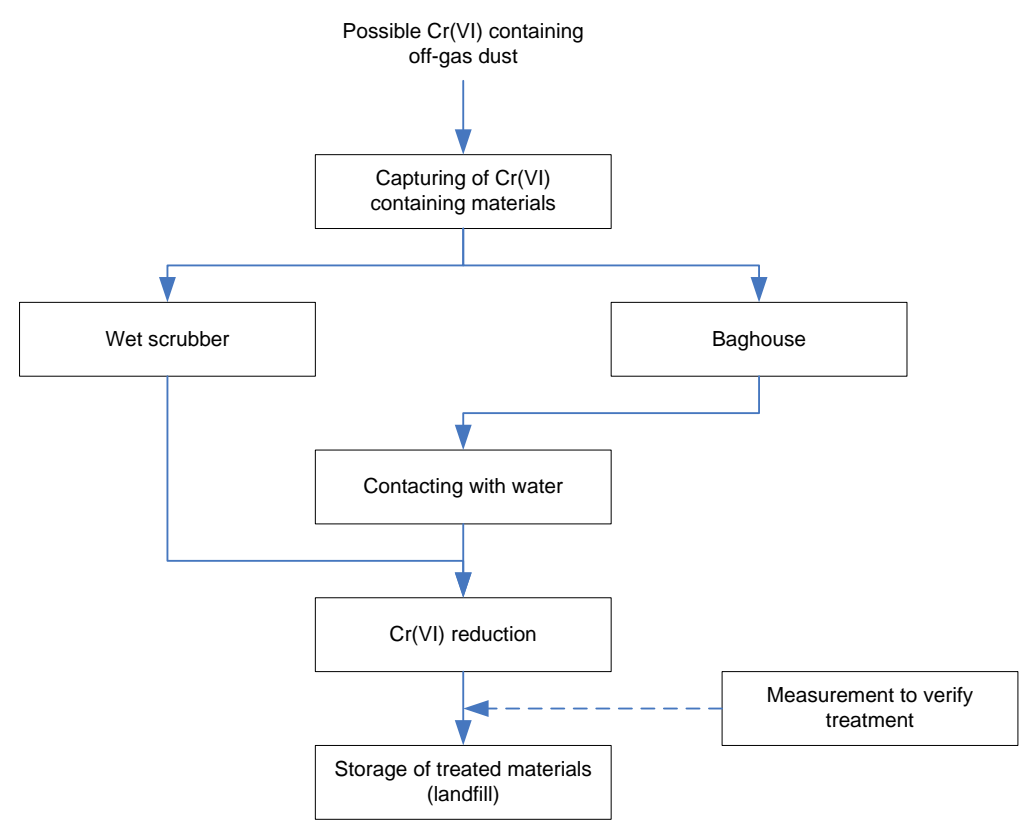

Figure 19: Steps for containing and treating of $\mathrm{Cr}(\mathrm{VI})$ waste.

(Beukes, et al., 2012)

A reducing agent, such as ferrous chloride $\left(\mathrm{FeCl}_{2}\right)$ or ferrous sulphate $\left(\mathrm{FeSO}_{4}\right)$ is added to the water in which $\mathrm{Cr}(\mathrm{VI})$ has been dissolved. Proper contact between the reagents can be ensured by mixing in a turbulent sump pump or agitated vessel. The $\mathrm{Cr}(\mathrm{III})$ precipitates that form as a result of the reduction reactions are $\mathrm{Cr}(\mathrm{OH})_{3}(\mathrm{~s})$, $\mathrm{FeCr}_{2} \mathrm{O}_{4}(\mathrm{~s})$ and $\mathrm{Fe}_{\mathrm{x}} \mathrm{Cr}_{\mathrm{y}}(\mathrm{OH})_{3}(\mathrm{~s})$ (Hawley, et al., 2005).

The cost components that need to be allowed for are the water used for $\mathrm{Cr}(\mathrm{VI})$ dissolution, reducing agent, agitation system (sump pump or agitated tank), filtration system and sampling and analysis costs.

Najm, et al. (2014) conducted an extensive study on the capital and operating costs associated with the treatment and disposal of $\mathrm{Cr}(\mathrm{VI})$. Correlations were drawn as a function of the water treatment rate (Eq. 1 and 2).

$$
\begin{array}{ll}
\text { Capital cost }(U S D, 2012)=205191 \times Q^{0.4531} & \ldots E q .1 \\
\text { Operating cost (USD/year, 2012) }=139858+134.6 \times Q & \ldots \text { Eq. } 2
\end{array}
$$


Where $Q$ is the treatment rate in gallons per minute.

Diluting $\mathrm{Cr}(\mathrm{VI})$ in a similar ratio to that used in the ASTM leaching test (American Standards Tests for Materials, 2004) (50 g dust per litre of water), requires approximately 0.450 kilolitres of water for every tonne of LC FeCr. For a typical plant producing 40000 tonnes of LC FeCr per year, 2.75 kilolitres of water is required per hour to dissolve $\mathrm{Cr}(\mathrm{VI})$ (12.2 gpm).

Substituting the treatment rate into Equations 1 and 2, yields a capital cost of $\$ 636$ 935 and an operating cost of \$ 141498 per year, in 2012 United States Dollars. These values are dependent on a number of factors, such as the location of the plant, source of equipment and raw materials, availability of water, and so forth. However, it does give an indication of the order of magnitude of the costs for the treatment and disposal of $\mathrm{Cr}(\mathrm{VI})$.

\subsubsection{Comparison of $\mathrm{Cr}(\mathrm{VI})$ Formation for Processes}

The main area of concern for the formation of $\mathrm{Cr}(\mathrm{VI})$ is in the ore-lime melt furnace for the Mixing Method and in the LC FeCr furnace for the Furnace Method. The primary difference between the Perrin and the Duplex processes is the handling of the furnace products. The conditions in the ore-lime melt furnace would therefore be similar for both. Also, the conditions in the LC FeCr furnace are expected to be similar for the SFFM and the LFFM. This evaluation is therefore focussed on the broader Mixing Method and Furnace Method and no distinctions were made between the type of Mixing and Furnace Method processes.

An open furnace (such as the ore-lime melt furnaces used in the Mixing Method) would be more prone to $\mathrm{Cr}(\mathrm{VI})$ formation than a closed furnace (such as the LC FeCr furnaces used in the Furnace Method), as discussed in Section 3.3.2. A higher basicity slag will also promote the formation of $\mathrm{Cr}(\mathrm{VI})$. On both accounts the Mixing Method is therefore expected to produce more $\mathrm{Cr}(\mathrm{VI})$.

\section{Mixing Method}

Thermochemical modelling was done to determine the thermodynamic limit of $\mathrm{Cr}(\mathrm{VI})$ formation for the Mixing Method. The chromite ore to lime ratio was selected to yield a slag product containing approximately $27 \% \quad \mathrm{Cr}_{2} \mathrm{O}_{3}$ equivalent. The required ratio was established to be 1.22 grams of chromite per gram of lime. The liquidus temperature for this mixture was calculated to be $1831^{\circ} \mathrm{C}$.

At $1900^{\circ} \mathrm{C}$, the operating temperature, the amount of $\mathrm{Cr}(\mathrm{VI})$ that reports to the dust is $2.52 \mathrm{~g} / \mathrm{t}$ ore. This is as a result of the fuming and subsequent oxidation of chromium and/or chromium oxide. Considering that 1.5 tonnes of ore is required to produce one tonne of LC FeCr (Table 8), approximately $3.8 \mathrm{~g}$ of $\mathrm{Cr}(\mathrm{VI})$ is generated for every tonne of LC FeCr produced.

The $\mathrm{Cr}(\mathrm{VI})$ content of bag filter dust samples, collected from an existing Perrin process operation, was also determined by the ASTM D3987-85 method (American Standards Tests for Materials, 2004). The test entailed drying of the sample and 
leaching in distilled water (while continuously agitating the mixture for 18 hours). After solid-liquid separation, the filtrate was analysed to determine the $\operatorname{Cr}(\mathrm{VI})$ content.

The $\mathrm{Cr}(\mathrm{VI})$ content of the dust sample was determined to be $0.10 \%(0.62 \%$ of total chromium), which amounts to more than $23 \mathrm{~g}$ of $\mathrm{Cr}(\mathrm{VI})$ generated for every tonne of LC FeCr produced. Considering that the limit in water is $0.5 \mathrm{mg} / \mathrm{l}$ (Section 3.3.1), this has the potential to contaminate more than 46 kilolitres of groundwater for every tonne of LC FeCr produced, assuming that all of the $\mathrm{Cr}(\mathrm{VI})$ from the dust is leached to the ground water.

The difference in the amount of $\mathrm{Cr}(\mathrm{VI})$ predicted by modelling and that determined by test work leads to the conclusion that $\mathrm{Cr}(\mathrm{VI})$ predictions by thermochemical modelling is not accurate, or that only a very small percentage $(0.2 \%)$ of the total $\mathrm{Cr}(\mathrm{VI})$ generated is as a result of fuming (vaporisation). The remainder therefore originates from slag splashing and feed material short circuiting to the off-gas system (and its subsequent oxidation). For the Mixing Method, the air ingress rate was calculated to be $35000 \mathrm{Nm}^{3} / \mathrm{t}$ chromite, based on the bag house capacity at the operation in Turkey. This could explain the high rate of solid material carry over to the off-gas system.

\section{Furnace Method}

For the Furnace Method, modelling predicted no $\mathrm{Cr}(\mathrm{VI})$ to be present. This is due to the reducing conditions in the furnace. As a closed furnace would be used, the air ingress rate would be much lower than for the mixing method. Considering the fact that little to no gas is generated by the process, the only off-gas would be due to fuming and air leakage. The amount of ingress air would depend on the furnace size and design, but is expected to be less than $30 \mathrm{Nm}^{3} / \mathrm{t}$ chromite. To decrease the offgas temperature from $1750^{\circ} \mathrm{C}$ (the process temperature) to less than $200^{\circ} \mathrm{C}$, additional air needs to be introduced at the off-gas duct inlet. Approximately 10 times the amount of additional air is required. The total gas flow rate is therefore less than $350 \mathrm{Nm}^{3} / \mathrm{t}$ chromite. This is significantly less than the $35000 \mathrm{Nm} 3 / \mathrm{t}$ chromite required for the Mixing Method and would result in much lower raw material and slag and metal droplet (from splashing) carry over to the off-gas. Unfortunately, at the time of writing, no data or samples were available to confirm this. 


\section{THERMOCHEMICAL MODELLING}

At the time of writing there was no commercial installation producing low carbon ferrochrome by the LFFM. No information was therefore available relating to the operational parameters required to promote the product quality and recovery, nor for the refractory and slag systems that are the most appropriate for the process.

Thermochemical modelling was subsequently performed to evaluate different slag compositions and refractory materials to ascertain whether or not low carbon ferrochrome can be produced that is within specification, whether or not the process would be operable in terms of the slag liquidus temperature (and superheat) and to determine if the slag and refractory materials would be chemically compatible at the selected process temperature.

The first step was to identify the process restrictions. All modelling had to be done within these boundaries. Different setups and systems were then identified to ensure that as many options were considered that could potentially work. Modelling was then done in FactSage 6.4 for each system.

Although the modelling was done for the Liquid Feed Furnace Method, this section is applicable to the Solid Feed Furnace Method as well, as the only difference between the processes is in the operation and energy balance, which is not addressed in this section.

A description of the methodology followed for developing the thermochemical models has been included in Appendix B.

\subsection{Restrictions}

Before selecting the systems to evaluate, certain restrictions had to be identified.

When selecting a refractory system and slag composition, the capital and operating costs must be limited. Low cost materials that are readily available and that limit the amount of slag that is formed therefore has to be selected, as high slag volumes generally increase the power consumption (more material to melt).

As discussed in Section 3.2.1.3, the required operating temperature should be approximately $1750^{\circ} \mathrm{C}$, while the slag liquidus temperature should be between 1550 and $1700^{\circ} \mathrm{C}$.

A slag is required to be basic in order to be chemically compatible with the basic magnesia refractories, as well as for maximising the recovery of chromium (Holappa \& Xiao, 2004).

\subsection{Systems}

Refractory systems were limited to magnesia, doloma and alumina, as they are readily available and low cost. Magnesia-chrome refractories, even though they are readily available, were not considered due to the ease with which silicon metal would 
reduce the chromite. Fluxes were limited to lime, doloma and quartz, again due to their availability and cost. The systems that were modelled are listed in Table 20.

Table 20: Slag-refractory systems modelled.

\begin{tabular}{|c|c|c|}
\hline System number & Refractory & Flux \\
\hline 1 & Magnesia & Lime \\
\hline 2 & Doloma & Lime \\
\hline 3 & Doloma & Doloma \\
\hline 4 & Magnesia & Doloma \\
\hline 5 & Alumina & Quartz \\
\hline
\end{tabular}

For the purposes of modelling, magnesia, lime, alumina and quartz were considered to be pure $\mathrm{MgO}, \mathrm{CaO}, \mathrm{Al}_{2} \mathrm{O}_{3}$ and $\mathrm{SiO}_{2}$ respectively. The composition of doloma used in the modelling, is shown in Table 21. The LOI fraction was not included in the model, as it would not report to the slag phase.

Table 21: Doloma analysis.

\begin{tabular}{|l|c|c|}
\hline Doloma & Unit & Value \\
\hline $\mathrm{Al}_{2} \mathrm{O}_{3}$ & wt $\%$ & 1.3 \\
\hline $\mathrm{CaO}$ & wt $\%$ & 55.4 \\
\hline $\mathrm{FeO}$ & wt $\%$ & 3.5 \\
\hline $\mathrm{MgO}$ & wt $\%$ & 36.9 \\
\hline $\mathrm{SiO}_{2}$ & wt $\%$ & 2.9 \\
\hline $\mathrm{Total}$ & wt $\%$ & 100.0 \\
\hline
\end{tabular}

Basic slag systems are normally used for ferrochrome production due to the improved recovery of chromium to the metal phase (Pretorius \& Muan, 1992). The reason for this is briefly explained below. 
The standard Gibbs free energy is:

$$
\Delta G^{0}=-R T \ln K
$$

Where $\mathrm{R}$ is the universal gas constant, $\mathrm{T}$ is the temperature and $\mathrm{K}$ is the equilibrium constant.

For non-equilibrium conditions, the Gibbs free energy is:

$$
\Delta G=\Delta G^{0}+R T \ln Q
$$

Where $Q$ is the reaction quotient for non-equilibrium conditions.

Substituting Eq. (1) into Eq. (2):

$$
\begin{aligned}
\Delta G & =-R T \ln K+R T \ln Q \\
\Delta G & =R T \ln \left(\frac{Q}{K}\right)
\end{aligned}
$$

For this discussion we consider a slag with a low basicity as the base case (due to the smaller slag volume and energy required for smelting). If the conditions were to change by increasing the slag basicity (increase in $\mathrm{CaO}$ or $\mathrm{MgO}$ ), the equilibrium would also change. At a constant temperature, when $\mathrm{Q} / \mathrm{K}<1$, the Gibbs free energy would be more negative and the reaction would be thermodynamically possible.

Silicothermic reduction of chromium occurs as per the simplified reaction:

$$
2 \mathrm{Cr}_{2} \mathrm{O}_{3}+3 \mathrm{Si}=4 \mathrm{Cr}+3 \mathrm{SiO}_{2}
$$

The reaction quotient is:

$$
Q=\frac{a_{S i O 2}^{3} \cdot a_{C r}^{4}}{a_{S i}^{3} \cdot a_{C r 2 O 3}^{2}}
$$

When the reaction is at equilibrium, adding $\mathrm{CaO}$ or $\mathrm{MgO}$ decreases the concentration (and therefore the activity) of $\mathrm{SiO}_{2}$, resulting in a decrease in $\mathrm{Q}$. The activity of $\mathrm{Cr}$ and Si would initially remain unchanged, as they form part of a different phase. $Q / K$ would therefore be less than 1 and the reaction Gibbs free energy would be negative, causing the new reaction to proceed spontaneously. This then increases the recovery of $\mathrm{Cr}$ until a new equilibrium is reached.

Even though basic slag systems are preferred, the acidic slag with alumina refractory system has been included so as to identify any possible benefits that this regime may provide. If the benefits gained by using an acidic slag are substantial, such as lower power consumption, the lower recovery can be tolerated by washing the slag with high silicon FeSiCr after it has been tapped.

Although acidic systems have been included in the evaluation, for the most part discussions have been limited to basic slag systems.

\subsection{Control of Slag Properties}

A thermochemical model was developed to determine the natural slag basicity. In other words, the slag that forms when chromite ore is reduced with ferrochrome 
silicide in the absence of a fluxing agent. The analysis of FeSiCr used in the models, which was indicated in Table 3, is again shown in Table 22. The slag composition is shown in Table 23.

Table 22: FeSiCr Analysis used in Modelling.

\begin{tabular}{|l|c|c|}
\hline FeSiCr & Unit & Value \\
\hline $\mathrm{Cr}$ & wt $\%$ & 40.00 \\
\hline $\mathrm{Fe}$ & wt $\%$ & 18.00 \\
\hline $\mathrm{Si}$ & wt $\%$ & 42.00 \\
\hline
\end{tabular}

Table 23: Composition of final LC FeCr slag with no fluxing.

\begin{tabular}{|l|c|}
\hline Component & $\mathbf{W t} \%$ \\
\hline $\mathrm{Al}_{2} \mathrm{O}_{3}$ & $14.32 \%$ \\
\hline $\mathrm{CaO}$ & $0.46 \%$ \\
\hline $\mathrm{Cr}_{2} \mathrm{O}_{3}$ & $0.02 \%$ \\
\hline $\mathrm{CrO}$ & $5.00 \%$ \\
\hline $\mathrm{Fe}_{2} \mathrm{O}_{3}$ & $0.00 \%$ \\
\hline $\mathrm{FeO}$ & $0.06 \%$ \\
\hline $\mathrm{MgO}$ & $24.37 \%$ \\
\hline SiO & \\
\hline Total & $55.76 \%$ \\
\hline Basicity & $99.99 \%$ \\
\hline
\end{tabular}

The liquidus temperature of this slag is approximately $1354^{\circ} \mathrm{C}$ (FactSage 6.4), which is significantly lower than that of the low carbon ferrochrome product. The ideal operating temperature was identified as $1750^{\circ} \mathrm{C}$, which is 50 to $100^{\circ}$ above the liquidus temperature of the $\mathrm{LC} \mathrm{FeCr}$. Choosing a slag with a liquidus temperature much lower than $200^{\circ} \mathrm{C}$ below the operating temperature will result in a slag that is severely superheated and will do a great deal of damage to any material with which it is in contact, whether it is the furnace, launder or ladle refractories. The silica that 
forms as a result of the silicothermic reduction also poses a potential risk to the basic refractories, as well as decreasing the chromium recovery (as discussed in Section 4.2).

The addition of a fluxing agent, such as $\mathrm{CaO}$ or $\mathrm{MgO}$, mitigates both of these risks to an extent. Although the energy consumption is higher for a larger slag mass, the superheat is decreased and the tendency for the slag to react with the magnesia refractories is reduced.

The trends in the liquidus temperatures for increasing slag basicities with an increase in the lime, doloma and quartz addition is shown in Figure 20. Note that this is an extension of Figure 15. Quaternary systems with $\mathrm{Al}_{2} \mathrm{O}_{3}, \mathrm{CaO}, \mathrm{MgO}$ and $\mathrm{SiO}_{2}$ have been used, as these make up 90 to $95 \%$ of the slag composition. Other components may affect the liquidus temperature indicated in the diagrams to an extent. However, this system was used as an initial tool for evaluating if a slag system would fall within the required liquidus temperature range. The compositions have been normalised for $\mathrm{Al}_{2} \mathrm{O}_{3}$ contents of 5 and $10 \%$. Although the addition of fluxes dilutes the $\mathrm{Al}_{2} \mathrm{O}_{3}$ content, the diagrams in Figure 20 are the ones that best represent the system. The $10 \% \mathrm{Al}_{2} \mathrm{O}_{3}$ diagram is shown first, as the slag starts off with an $\mathrm{Al}_{2} \mathrm{O}_{3}$ content of close to $15 \%$ when adding no fluxing materials. As fluxes are added, the $\mathrm{Al}_{2} \mathrm{O}_{3}$ content rapidly decreases to $10 \%$ and below.

Using doloma as a flux rapidly moves the slag into the periclase phase field, where the isotherm spacing is much narrower. Small variations in the slag composition would therefore have a tremendous effect on the slag liquidus temperature. This is a reason why lime is more commonly used as the fluxing agent for controlling the slag liquidus temperature. Adding quartz as a flux would move the composition from the origin ( $\mathrm{B}=0.45$ ), along the $\mathrm{MgO}-\mathrm{SiO}_{2}$ binary system towards $90 \% \mathrm{SiO}_{2}$, ending in the Cristobalite phase field at a maximum liquidus temperature of $1670^{\circ} \mathrm{C}$ for the $10 \%$ $\mathrm{Al}_{2} \mathrm{O}_{3}$ diagram. The approximate liquidus temperatures are shown in Table 24. 

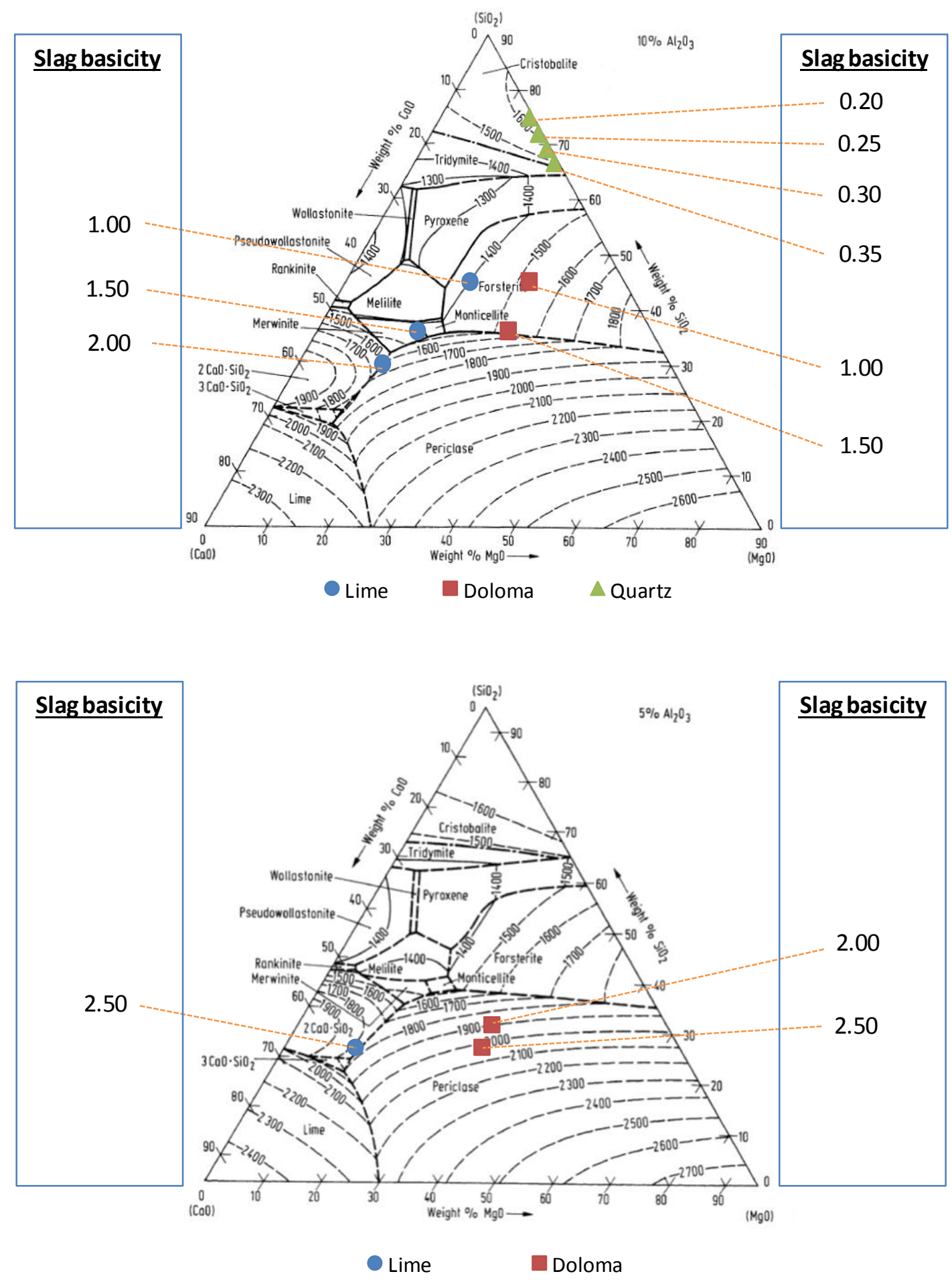

Figure 20: $\mathrm{Al}_{2} \mathrm{O}_{3}-\mathrm{CaO}-\mathrm{MgO}-\mathrm{SiO}_{2}$ quaternary phase diagrams, indicating liquidus temperatures for lime, doloma and quartz flux additions.

(Slag Atlas, 2008)

\section{Page 50}


Table 24: Slag liquidus temperature for different fluxes and basicities.

(Estimated from Slag Atlas, 2008)

\begin{tabular}{|c|c|c|c|c|c|c|}
\hline Basicity & \multicolumn{2}{|c|}{ Lime flux } & \multicolumn{2}{c|}{ Doloma flux } & \multicolumn{2}{c|}{ Quartz flux } \\
\hline & $\mathrm{T}_{\text {liq }}$ & $\begin{array}{c}\mathrm{Al}_{2} \mathrm{O}_{3} \\
\text { plane }\end{array}$ & $\mathrm{T}_{\text {liq }}$ & Diagram* & $\mathrm{T}_{\text {liq }}$ & $\begin{array}{c}\mathrm{Al}_{2} \mathrm{O}_{3} \\
\text { plane }\end{array}$ \\
\hline 0.20 & & & & & $1670^{\circ} \mathrm{C}$ & $10 \% \mathrm{Al}_{2} \mathrm{O}_{3}$ \\
\hline 0.25 & & & & & $1620^{\circ} \mathrm{C}$ & $10 \% \mathrm{Al}_{2} \mathrm{O}_{3}$ \\
\hline 0.30 & & & & & $1550^{\circ} \mathrm{C}$ & $10 \% \mathrm{Al}_{2} \mathrm{O}_{3}$ \\
\hline 0.35 & & & & & $1510^{\circ} \mathrm{C}$ & $10 \% \mathrm{Al}_{2} \mathrm{O}_{3}$ \\
\hline 0.45 & $1430^{\circ} \mathrm{C}$ & $15 \% \mathrm{Al}_{2} \mathrm{O}_{3}$ & $1430^{\circ} \mathrm{C}$ & $15 \% \mathrm{Al}_{2} \mathrm{O}_{3}$ & $1430^{\circ} \mathrm{C}$ & $15 \% \mathrm{Al}_{2} \mathrm{O}_{3}$ \\
\hline 1.00 & $1405^{\circ} \mathrm{C}$ & $10 \% \mathrm{Al}_{2} \mathrm{O}_{3}$ & $1520^{\circ} \mathrm{C}$ & $10 \% \mathrm{Al}_{2} \mathrm{O}_{3}$ & & \\
\hline 1.50 & $1440^{\circ} \mathrm{C}$ & $10 \% \mathrm{Al}_{2} \mathrm{O}_{3}$ & $1530^{\circ} \mathrm{C}$ & $10 \% \mathrm{Al}_{2} \mathrm{O}_{3}$ & & \\
\hline 2.00 & $1600^{\circ} \mathrm{C}$ & $10 \% \mathrm{Al}_{2} \mathrm{O}_{3}$ & $1900^{\circ} \mathrm{C}$ & $5 \% \mathrm{Al}_{2} \mathrm{O}_{3}$ & & \\
\hline 2.50 & $1790^{\circ} \mathrm{C}$ & $5 \% \mathrm{Al}_{2} \mathrm{O}_{3}$ & $2010^{\circ} \mathrm{C}$ & $5 \% \mathrm{Al}_{2} \mathrm{O}_{3}$ & & \\
\hline
\end{tabular}

* $\mathrm{Al}_{2} \mathrm{O}_{3}$ plane in the $\mathrm{Al}_{2} \mathrm{O}_{3}-\mathrm{CaO}-\mathrm{MgO}-\mathrm{SiO}_{2}$ quaternary phase diagram that is the nearest approximation to the composition at the specified basicity.

For both lime and doloma additions, an increase in the slag basicity results in an increase in the slag liquidus temperature, although there is a slight decrease up to a basicity of 1.0 for the lime slag. An increase in the slag basicity also decreases the $\mathrm{MgO}$ solubility in the slag (Pretorius, 2010) (Figure 21). Even though the operating temperature required for the Liquid Feed Furnace Method is $1750^{\circ} \mathrm{C}$, the temperature near the furnace sidewall is expected to be much lower. Figure 21 should therefore be a fair representation of the $\mathrm{MgO}$ solubility in the slag near the sidewall. 


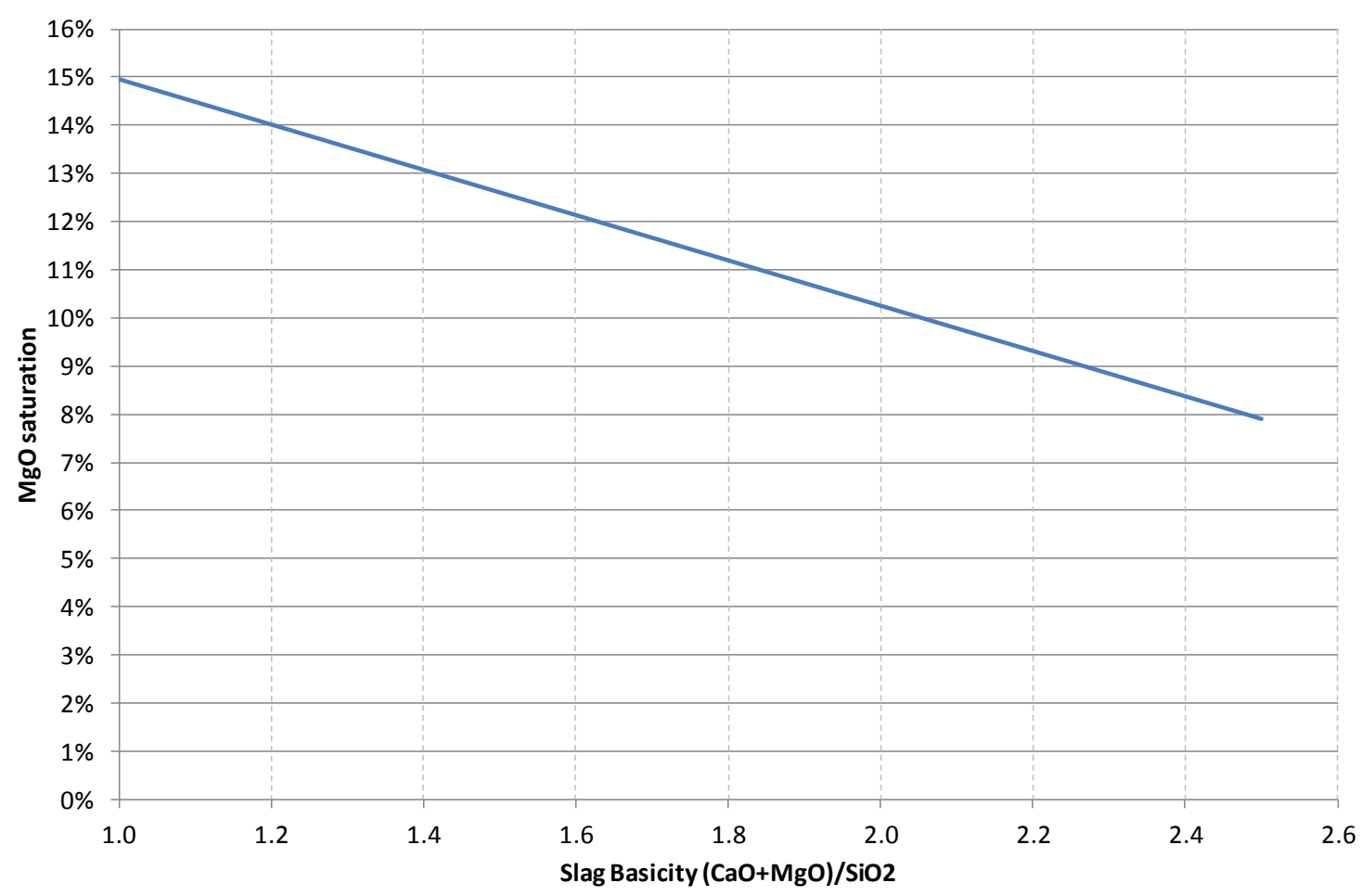

Figure 21: Solubility of $\mathrm{MgO}$ in slag at $1600^{\circ} \mathrm{C}$.

(Adapted from (Pretorius, 2010) to include $\mathrm{Al}_{2} \mathrm{O}_{3}$ and basicity as $(\mathrm{CaO}+\mathrm{MgO}) / \mathrm{SiO}_{2}$ )

The greater slag mass would understandably increase the energy consumption, so a balance needs to be found between the life of the refractory lining, chromium recovery and the production cost.

\subsection{Slag Chemistry Variation throughout Heat}

In the conventional Perrin process (Mixing Method) followed at the reference site in Turkey, the slag basicity is typically 2.0 to 2.5 . This is governed by the targeted $27 \%$ $\mathrm{Cr}_{2} \mathrm{O}_{3}$ in the ore-lime melt furnace. A chromite / lime ratio of $\sim 1.25$ is required to ensure that the liquidus temperature of the ore-lime melt is low enough to limit solidification during handling, but not so low as to result in damage to the furnace and ladle linings.

The presence of $\mathrm{SiO}_{2}$ from the reduction reactions will decrease the slag basicity when using the Furnace Method. A slag basicity range of 1.5 to 2.0 was chosen as the initial target, as decreasing too much below this basicity range would result in liquidus temperatures well below the required $1550^{\circ} \mathrm{C}$ (Figure 20).

\subsubsection{Basicity of Bulk Slag}

Simple mass and energy balances were done for both target basicities. The results are shown in Figure 22. The change in chemistry is described by referring to three 
principal measures, namely the alloy $\mathrm{Si}$ content, slag $\mathrm{Cr}_{2} \mathrm{O}_{3}$ content and the slag basicity. The reasons for choosing these three measures are:

The specification for $\mathrm{Si}$ in the product is $<1 \%$. This is also the reductant in the process and its presence is therefore indicative of the "chemical work" that has been done.

Although there is no specification for the slag $\mathrm{Cr}_{2} \mathrm{O}_{3}$, a lower amount is targeted in order to maximise recovery of chromium to the alloy.

Should the furnace freeze lining be lost, the slag basicity will directly impact on the slag-refractory interaction (refractory wear).

For this evaluation, an arbitrary heat time of 2 hours was chosen, with a tapping time of 15 minutes and 20 minutes settling time. The total feed time is therefore 85 minutes. The duration of the heat will depend on the tap sizes chosen for the plant. However, this will not affect the progression of the heat chemistry described herein. As mentioned, the duration of the holding period will depend on the reaction kinetics and may be changed to optimise the process. However, the 20 minutes selected for this evaluation is considered to be a reasonable starting point. This may be adjusted to ensure that near-equilibrium compositions are achieved.

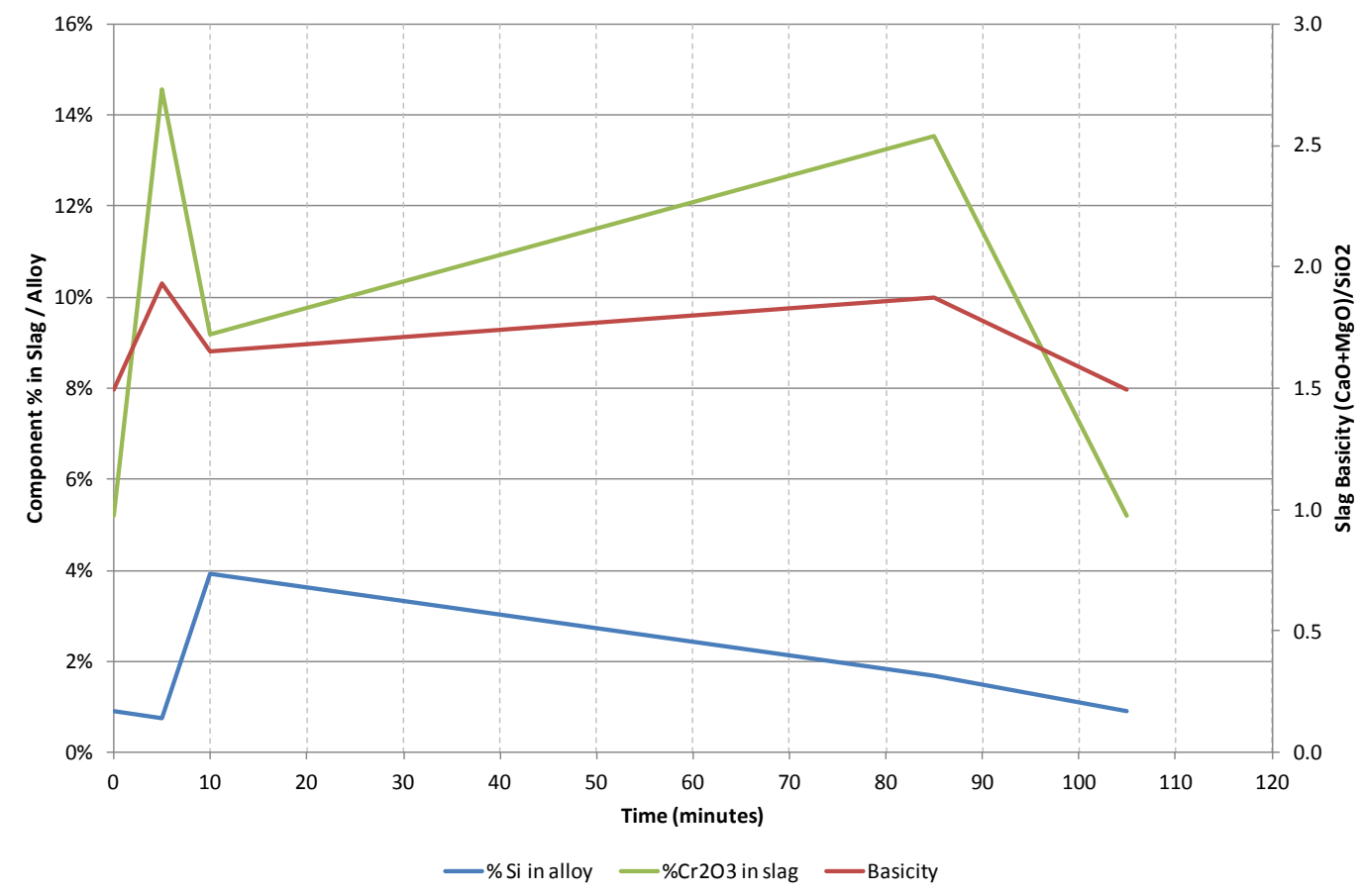

(a) Slag Basicity Target $=1.5$ 


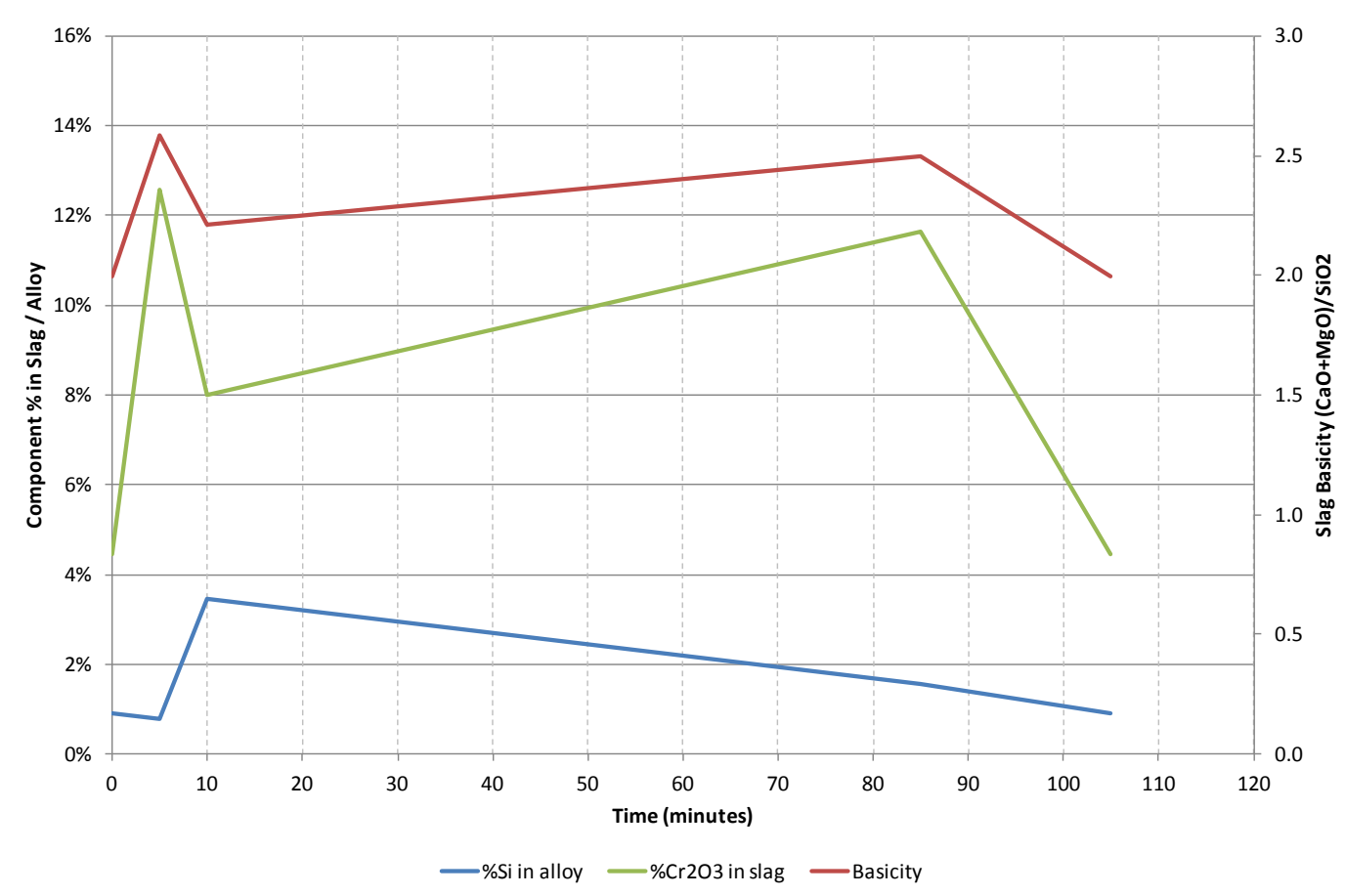

(b) Slag Basicity Target $=2.0$

Figure 22: Slag chemistry variation for two basicity target values.

\section{Time $=0$ minutes}

At the start of the heat, the furnace will have a molten alloy heel with a composition similar to the final alloy product $(\mathrm{Si}<1 \%)$. Some slag will also be left in the furnace after tapping so as to ensure electrical arc stability and to limit the heat losses. The slag will therefore start with a $\% \mathrm{Cr}_{2} \mathrm{O}_{3}$ and basicity similar to that of the final slag.

Time $=0-5$ minutes

As chromite and lime are fed (combined $\% \mathrm{Cr}_{2} \mathrm{O}_{3}$ of $27 \%$ ), the slag $\% \mathrm{Cr}_{2} \mathrm{O}_{3}$ and basicity will increase. The change is relatively slow, as the material that is fed is diluted into the remaining slag. At the same time, the alloy \%Si will decrease slowly.

\section{Time $=\mathbf{5}-10$ minutes}

As the FeSiCr is introduced, the alloy \%Si will increase rapidly. Again, the amount of alloy fed to the furnace is low compared to the alloy heel, thereby preventing the \%Si from rising to very high levels. This moderates the aggressiveness of the exothermic reactions, thereby limiting the refractory wear.

At the same time, the $\% \mathrm{Cr}_{2} \mathrm{O}_{3}$ in the slag is decreased, even though the ore-lime mixture is also fed during this period. The slag basicity also decreases as more $\mathrm{SiO}_{2}$ is produced from the reduction of $\mathrm{Cr}_{2} \mathrm{O}_{3}$ and $\mathrm{Fe}_{2} \mathrm{O}_{3}$. 


\section{Time $=10-85$ minutes}

The remainder of the ore-lime mixture is fed during this period. The rate at which the reactants are fed is faster than the rate of reaction, causing the $\% \mathrm{Cr}_{2} \mathrm{O}_{3}$ and basicity in the slag to rise and the \%Si in the alloy to fall.

\section{Time $=85-105$ minutes (holding period)}

As no feed materials are added, the $\% \mathrm{Cr}_{2} \mathrm{O}_{3}$ and basicity in the slag will decrease and the \% $\mathrm{Si}$ in the alloy to fall to the final desired composition.

For a slag target basicity of 1.5 , the basicity throughout the heat varies between 1.5 and 2.0, while it ranges between 2.0 and just above 2.5 for a target basicity of 2.0. Although the slag and alloy chemistry changes throughout the heat, the alloy heel and slag retained between heats lessens the extent of compositional variations. The basicity range of 1.0 to 2.5 indicated in Figure 20 is therefore adequate to describe the interaction between the bulk slag and refractories.

An important point to note is that the basicity never decreases below the target value. The reason for this is that the lime to ore ratio is selected to achieve the desired basicity. Any $\mathrm{SiO}_{2}$ that forms due to the reduction of chromite therefore has sufficient $\mathrm{CaO}$ to react with. The upper limit of the basicity is limited by the amount of slag inventory retained in the furnace between heats, as well as the time during the heat at which the ore-lime mixture is added. The basicity upper limit can be minimised by only starting to feed the ore-lime mixture after $\mathrm{FeSiCr}$ has been added, or by retaining a larger slag inventory.

\subsubsection{Basicity at FeSiCr Feed Position}

The point where the $\mathrm{FeSiCr}$ is introduced into the furnace remains an area of concern. To address this, a model was developed in which $\mathrm{FeSiCr}$ was systematically introduced into an ore-lime mixture and vice versa. The purpose of this model was to ascertain whether or not there would be a localised low slag basicity which could interact with the basic refractory. Even though these results do not follow the heat progression discussed earlier, it is useful for identifying what the limits of the slag basicity range are.

The chromite concentrate and $\mathrm{FeSiCr}$ analyses used in the modelling are the same as those used in the mass and energy balances (Table 13).

\subsubsection{Addition of FeSiCr to Ore-Lime Mixture}

The starting composition of the ore-lime mixtures to which FeSiCr was added are shown in Table 25. The results are shown for a wide range of basicities, starting above the natural basicity of the slag (0.75), up to the upper limit of slag used in the Mixing Method (2.5). 
Table 25: Starting ore-lime mixture analysis to which FeSiCr was added.

\begin{tabular}{|l|r|r|r|r|r|r|}
\hline \multicolumn{2}{|l|}{ Target basicity } & $\mathrm{B}=0.75$ & $\mathrm{~B}=1.00$ & $\mathrm{~B}=1.50$ & $\mathrm{~B}=2.00$ & $\mathrm{~B}=2.50$ \\
\hline Ore/Lime & g $_{\text {ore }} / \mathrm{g}_{\text {lime }}$ & 7.87 & 4.35 & 2.33 & 1.60 & 1.14 \\
\hline $\mathrm{Al}_{2} \mathrm{O}_{3}$ & wt \% & 9.65 & 8.85 & 7.61 & 6.70 & 5.79 \\
\hline $\mathrm{CaO}$ & wt \% & 11.59 & 18.98 & 30.31 & 38.68 & 46.99 \\
\hline $\mathrm{Cr}_{2} \mathrm{O}_{3}$ & wt \% & 43.57 & 39.92 & 34.34 & 30.22 & 26.12 \\
\hline $\mathrm{Fe}_{2} \mathrm{O}_{3}$ & wt \% & 12.52 & 11.47 & 9.87 & 8.68 & 7.51 \\
\hline $\mathrm{MgO}^{2}$ & wt \% & 16.44 & 15.07 & 12.96 & 11.40 & 9.86 \\
\hline $\mathrm{SiO}_{2}$ & wt \% & 6.23 & 5.71 & 4.91 & 4.32 & 3.73 \\
\hline \multicolumn{2}{|l|}{$\mathrm{Starting} \mathrm{basicity}^{\mid}$} & 4.5 & 6.0 & 8.8 & 11.6 & 15.2 \\
\hline
\end{tabular}

The results for the FeSiCr addition to the ore-lime mixtures are graphically shown in Figure 23.

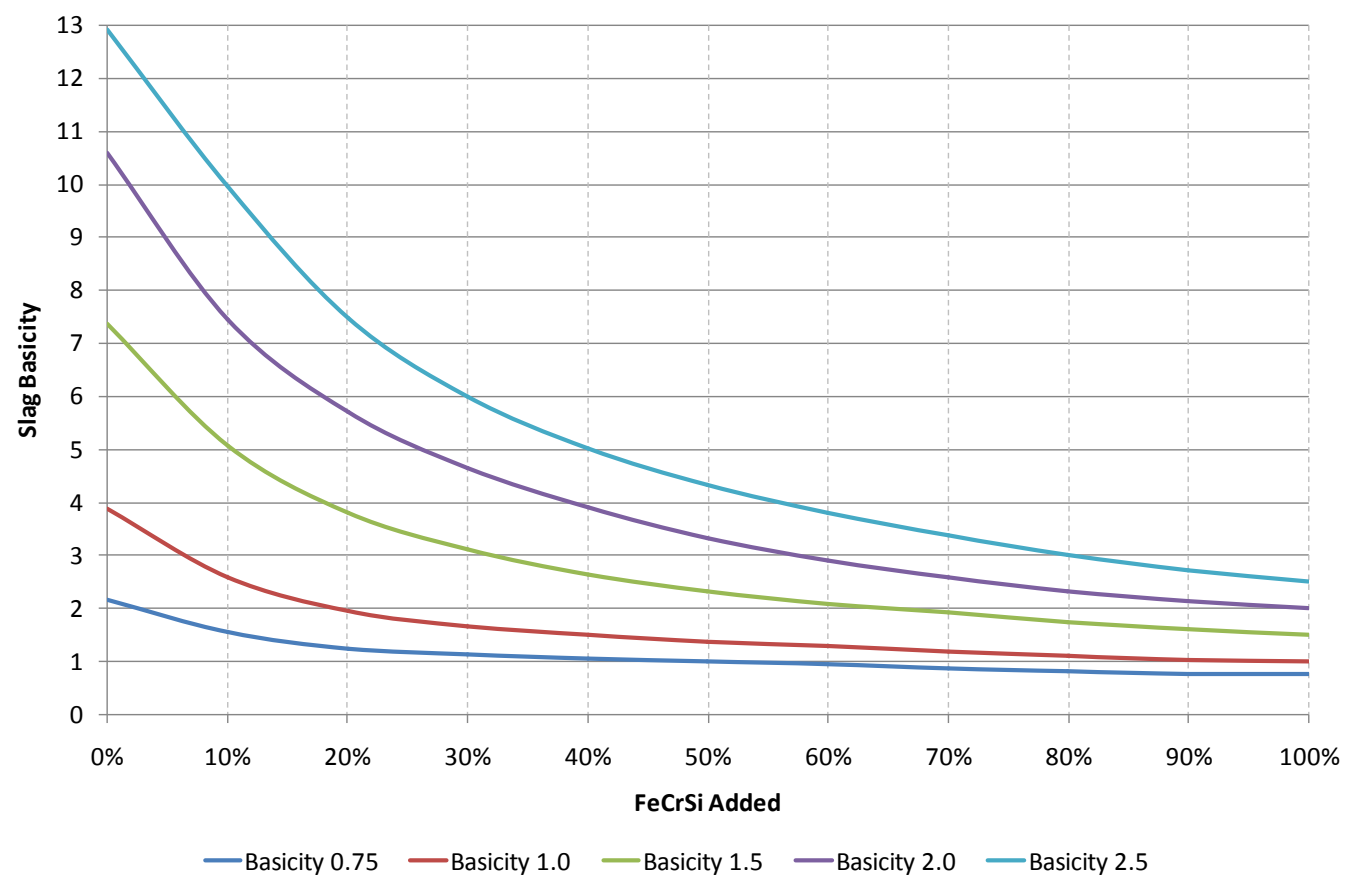

Figure 23: Slag basicity for systematic FeSiCr addition to ore-lime melt.

\section{Page 56}


Note that the starting basicities in Table 25 are somewhat higher than those in Figure 23. The reason for this is that the analysis in Table 25 is a weighted average of the analysis of the ore and lime in the mixture, while the results in Figure 23 show the actual predicted slag basicity. The difference between the two indicates that, at the temperature used in the model $\left(1750^{\circ} \mathrm{C}\right)$, some material is present in the solid state. Up to a slag basicity of 2.0, the solid phase is primarily $\mathrm{MgCr}_{2} \mathrm{O}_{4}$ spinel, but at a slag basicity of 2.5 the solid phase is mostly $\mathrm{CaO}$. This solid material will not have a detrimental effect on the refractory materials.

For the model where FeSiCr is systematically introduced into an ore-lime melt (Figure 23), there is an excess of lime before FeSiCr charging. The basicity therefore decreases and approaches the target value as more FeSiCr is added. The highest risk of refractory attack is therefore at the end of the heat, as the equilibrium composition is approached. Therefore, there is no risk of refractory damage, as long as the target slag composition (basicity) that is selected is compatible with the refractories.

\subsubsection{Addition of Ore-Lime Mixture to FeSiCr}

For the model where the ore-lime mixture is systematically introduced into a FeSiCr melt (Figure 24), the model indicates that the basicity starts off slightly below the target basicity and slowly approaches the target value as more ore-lime mixture is introduced. No data is shown for $0 \%$ ore-lime addition, as no slag has formed at this stage in the model. In practice, some slag will be retained between heats, so the basicity should start off at the target basicity and then drop off slightly as the ore-lime mixture is introduced.

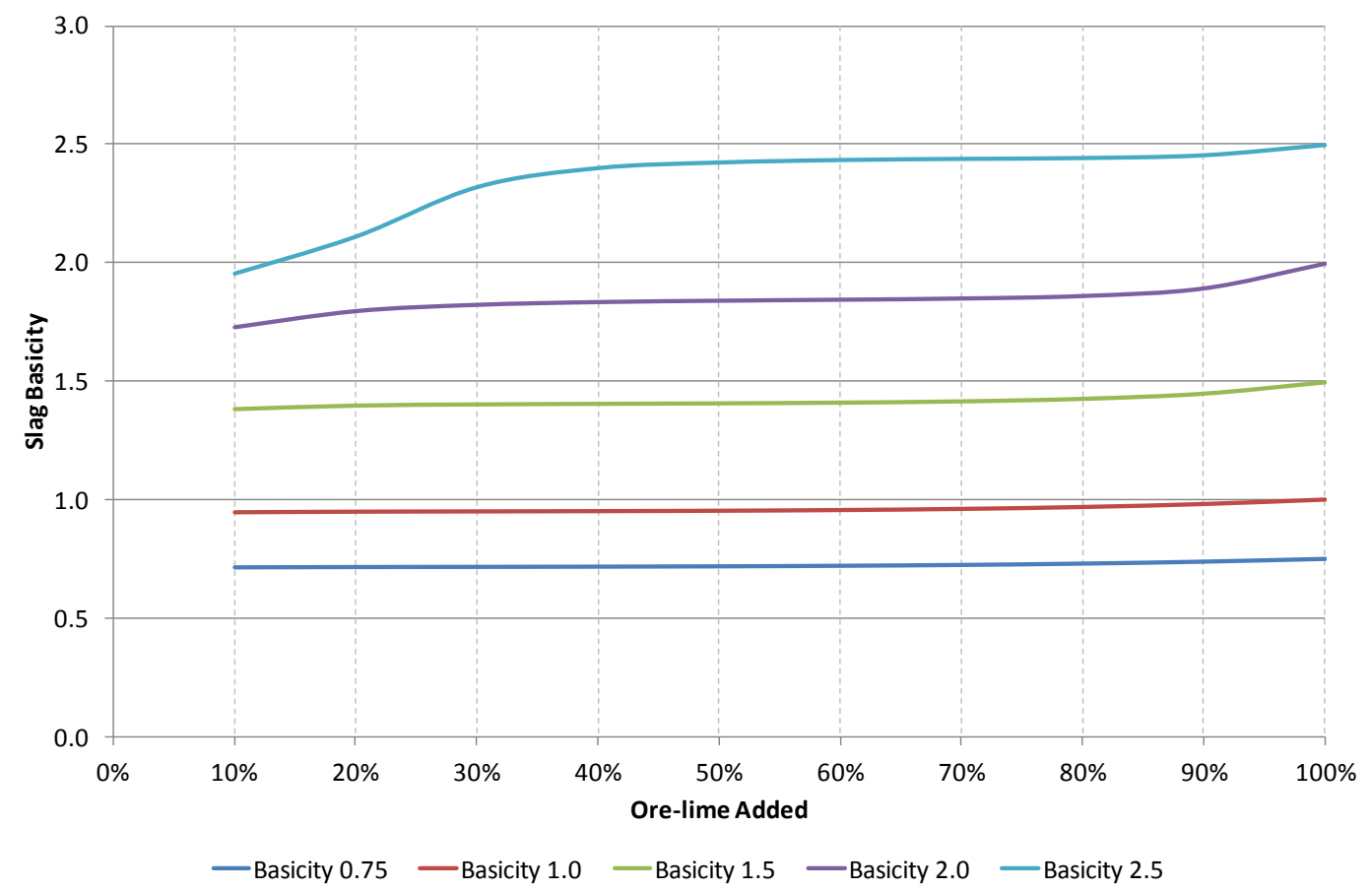

Figure 24: Slag basicity for systematic ore-lime addition to FeSiCr. 
One may have expected the basicity to remain constant for the entire range, as the $\mathrm{FeSiCr}$ has nothing to react with (hence no $\mathrm{SiO}_{2}$ formation) if no ore-lime is added. However, at low ore-lime additions (high alloy Si contents), the Mg content in the alloy was also found to be high. The silicon in the alloy therefore reduced a fraction of the $\mathrm{MgO}$ from the slag (Figure 25), causing the basicity to decrease. When feeding $\mathrm{FeSiCr}$ on the periphery of the furnace, Si could just as easily reduce $\mathrm{MgO}$ from the refractory lining.

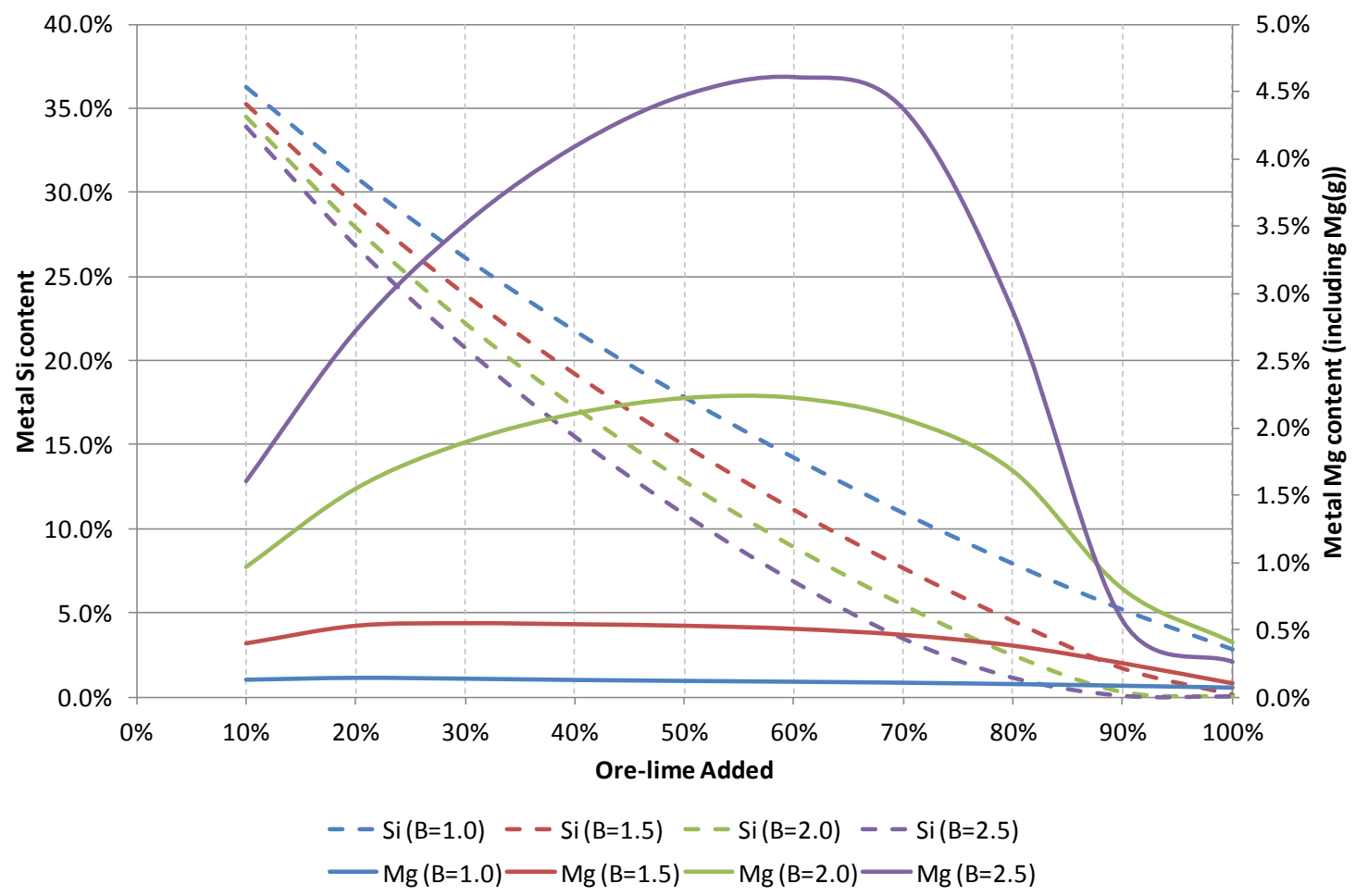

Figure 25: Metallic magnesium and silicon contents for basicities of 1.0 to 2.5.

The metal Mg content in Figure 25 includes the metallic $\mathrm{Mg}$ in the gas phase. For the entire range of basicities, the $\mathrm{Mg}_{(\mathrm{g})}$ as a percentage of total metallic $\mathrm{Mg}$, was more than $96 \%$.

In Figure 26, the standard Gibbs free energies are plotted for the reactions:

$$
\begin{array}{ll}
2 \mathrm{Mg}+\mathrm{O}_{2}=2 \mathrm{MgO} & \ldots \text { Eq. } 1 \\
\mathrm{Si}+\mathrm{O}_{2}=\mathrm{SiO}_{2} & \ldots \text { Eq. } 2
\end{array}
$$

The combined reaction (for the reduction of $\mathrm{Mg}^{2+}$ with $\mathrm{Si}$ ) is also shown in Figure 26.

$$
\mathrm{Si}+2 \mathrm{MgO}=\mathrm{SiO}_{2}+2 \mathrm{Mg} \quad \text {... Eq. } 3
$$




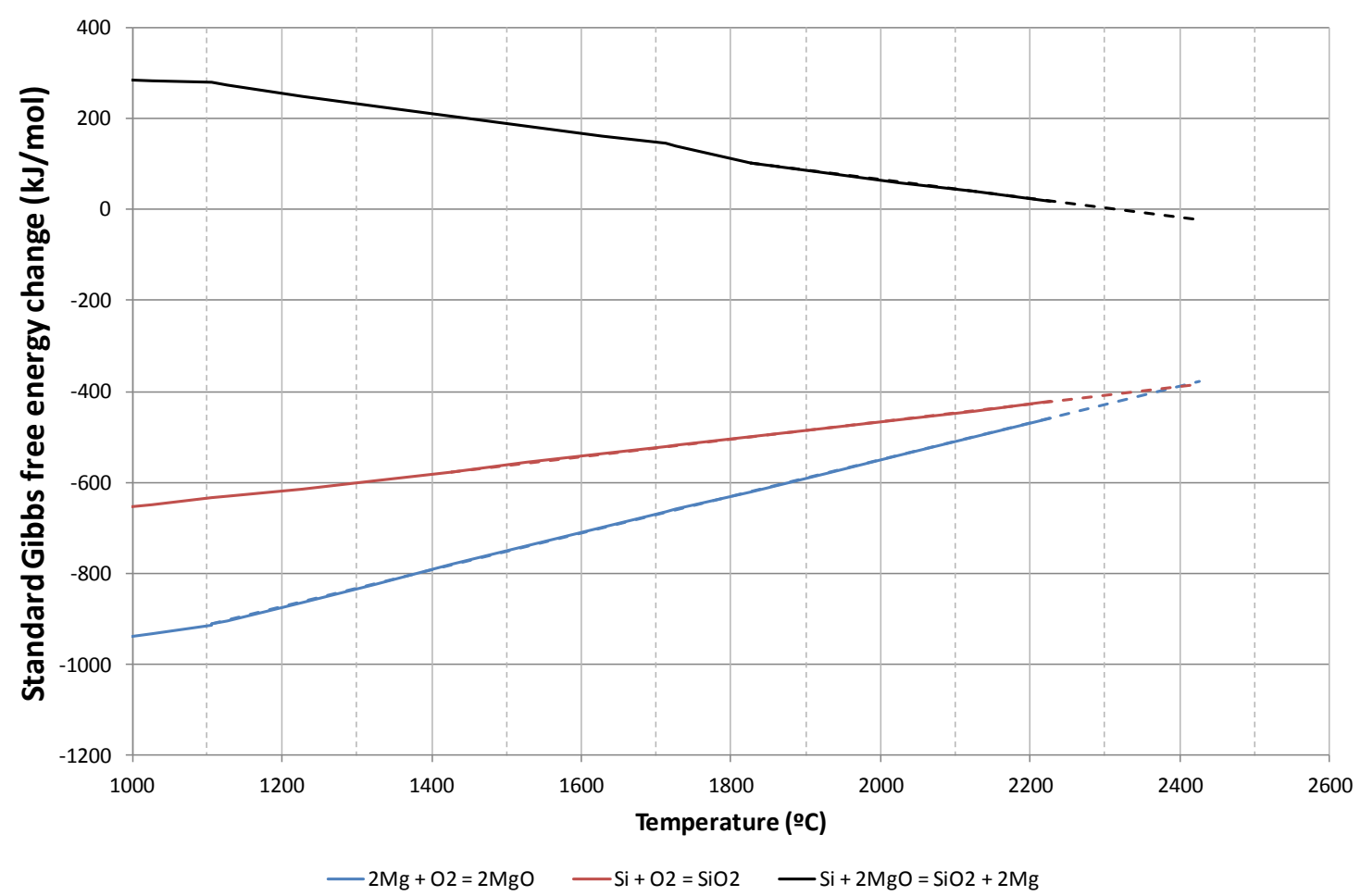

Figure 26: Standard Gibbs free energies for reactions for the dissociation of $\mathrm{MgO}$ and $\mathrm{SiO}_{2}$, as well as the reduction of $\mathrm{Mg}^{2+}$ with $\mathrm{Si}$.

(Adapted from Li, 2015).

The data shown in Figure 26 indicates that the standard Gibbs free energy ( $\left.\Delta \mathrm{G}^{\circ}\right)$ for Eq. 3 is positive for temperatures up to nearly $2400^{\circ} \mathrm{C}$, which means that the reaction will not occur spontaneously within the temperature range evaluated. However, the data is for components in unit activity.

Figure 25 shows the extent of magnesium reduction to be significant. It is interesting to note that the metallic magnesium increases dramatically with an increase in the slag basicity. For an alloy with a high silicon content, with an increase in the amount of $\mathrm{CaO}$ in the system, the silicon will reduce the magnesium. The reason is that the additional $\mathrm{CaO}$ results in a decrease in the activity of $\mathrm{SiO}_{2}$. For slag with a higher basicity, the combination of the high $a_{S i}$ in the alloy with the low $a_{\mathrm{SiO}_{2}}$ in the slag is sufficient to drive the reduction of $\mathrm{Mg}^{2+}$ (in $\mathrm{MgO}$ ) to metallic $\mathrm{Mg}$ (which reports mostly to the vapour phase).

Another interesting phenomenon is that the metallic $\mathrm{Mg}$ increases with an increase in the ore-lime addition. It reaches a peak at approximately $60 \%$ ore-lime mixture added, after which it decreases sharply. At the start of the heat, the $\mathrm{CrO}_{\mathrm{x}}$ and $\mathrm{FeO}_{\mathrm{x}}$ in the slag are low. The $\mathrm{Si}$ in the alloy therefore has limited material to react with. However, as the ore-lime addition is increased, the Si reacts preferentially with the $\mathrm{CrO}_{\mathrm{x}}$ and $\mathrm{FeO}_{\mathrm{x}}$. The reduction of $\mathrm{Mg}$ at low ore-lime additions is of concern, as the silicon will therefore react with the refractories in the vicinity of the FeSiCr feed port. 
The majority of the $\mathrm{Mg}$ that is reduced will likely come from the ore. However, where the FeSiCr alloy is in contact with the refractories, damage to the lining will invariably occur.

It would therefore be better to either feed the FeSiCr closer to the centre of the furnace where it would not make direct contact with the refractory sidewall, or to feed as much as possible of the ore-lime mixture into the furnace before introducing the FeSiCr. However, feeding all of the ore-lime mixture at the beginning is not ideal, as electrical energy will then be used to melt the mixture, instead of utilising the energy from the exothermic reactions. When introducing the FeSiCr later during the heat, the exothermic reactions will raise the process temperature to unacceptably high levels (thereby negating the benefit of following this process route). If the power input is not adjusted to melt all of the ore-lime mixture, the furnace temperature will be decreased and a crust will form on top of the slag bath. Feeding approximately half of the ore-lime mixture before feeding the $\mathrm{FeSiCr}$ may therefore be optimal, as the exothermic energy from the silicothermic reduction can be utilised to heat and melt the remaining ore-lime mixture.

\subsection{Thermochemical Modelling Results}

The range of basicities of the bulk slag that are expected to be present throughout the heat for two basicity targets was shown in Figure 22. As a minimum, the range of slag compositions evaluated in the model needed to encompass this range. However, as the preference is to operate at a lower basicity, the basicity range was extended down to 0.75 , which is slightly above the natural basicity of the slag that would form in the absence of the lime flux. Selecting a lower basicity for the modelling also ensures that instances where the basicity does fall below the target value have been addressed. A slag basicity upper limit of 2.5 was selected for the modelling. This is slightly above that of the slag that is formed in the existing Mixing Method operation (Table 26). 
Table 26: Typical slag composition for Mixing Method operation.

\begin{tabular}{|l|c|c|}
\hline Slag & Unit & Value \\
\hline $\mathrm{Al}_{2} \mathrm{O}_{3}$ & wt \% & 6.91 \\
\hline $\mathrm{CaO}$ & wt \% & 51.43 \\
\hline $\mathrm{Cr}_{2} \mathrm{O}_{3}$ & wt \% & 1.98 \\
\hline $\mathrm{MgO}$ & wt \% & 12.30 \\
\hline $\mathrm{SiO}_{2}$ & wt \% & 27.38 \\
\hline $\mathrm{Total}$ & Wt \% & 100.00 \\
\hline Slag basicity & & 2.33 \\
\hline
\end{tabular}

The basicity limits for the acidic slag and refractory system obviously falls outside of the range specified above. The basicity range will be discussed with the results.

Modelling results for the chosen systems (Table 20) are discussed in the remainder of this section. Particular reference is made to the reaction products, the slag liquidus temperature and the interaction between the slag and refractory materials.

\subsubsection{Magnesia Refractories, Lime Slag}

\subsubsection{Reaction Products}

The results of thermochemical modelling identified the reaction products for a range of raw material ratios. This indicated whether or not the required low carbon ferrochrome product can be formed with the raw material inputs.

$100 \mathrm{~g}$ of concentrate was used as the basis for the calculations. The FeSiCr addition was changed to get a total slag chrome oxide content of $5-6 \%$, expressed as $\mathrm{Cr}_{2} \mathrm{O}_{3}$. This is slightly higher than the range of $2-3 \% \mathrm{Cr}_{2} \mathrm{O}_{3}$ identified in Section 2.3. This was done deliberately, as allowance should be made for a washing step after tapping the slag from the furnace.

The lime addition was changed to get a basicity of $0.75,1.0,1.5,2.0$ and 2.5. A model was also set up to evaluate the natural basicity of the slag, in other words, the slag that would be present if no lime was added. The reaction products for the different basicities, using lime as a flux, are shown in Table 27. 
Table 27: Reaction products from thermochemical modelling, lime flux, temperature $=1750^{\circ} \mathrm{C}$.

\section{FEED}

\begin{tabular}{|l|r|r|r|r|r|r|r|}
\hline $\begin{array}{l}\text { Target } \\
\text { Basicity }\end{array}$ & & $\begin{array}{c}\text { Natural } \\
\text { (no lime) }\end{array}$ & 0.75 & 1.00 & 1.50 & 2.00 & 2.50 \\
\hline Concentrate & $\mathrm{g}$ & 100.0 & 100.0 & 100.0 & 100.0 & 100.0 & 100.0 \\
\hline FeSiCr & $\mathrm{g}$ & 60.0 & 50.0 & 45.0 & 39.5 & 37.5 & 36.5 \\
\hline Lime & $\mathrm{g}$ & 0.0 & 12.7 & 23.0 & 43.0 & 62.5 & 88.0 \\
\hline
\end{tabular}

\section{SLAG}

\begin{tabular}{|l|r|r|r|r|r|r|r|}
\hline $\mathrm{Al}_{2} \mathrm{O}_{3}$ & wt $\%$ & $14.32 \%$ & $12.22 \%$ & $10.92 \%$ & $9.06 \%$ & $7.77 \%$ & $6.84 \%$ \\
\hline $\mathrm{SiO}_{2}$ & wt $\%$ & $55.76 \%$ & $47.21 \%$ & $41.96 \%$ & $34.43 \%$ & $29.00 \%$ & $25.18 \%$ \\
\hline $\mathrm{CaO}$ & wt $\%$ & $0.46 \%$ & $14.64 \%$ & $23.42 \%$ & $36.07 \%$ & $44.83 \%$ & $55.61 \%$ \\
\hline $\mathrm{FeO}$ & wt \% & $0.06 \%$ & $0.05 \%$ & $0.04 \%$ & $0.04 \%$ & $0.05 \%$ & $0.08 \%$ \\
\hline $\mathrm{MgO}$ & wt \% & $24.37 \%$ & $20.79 \%$ & $18.58 \%$ & $15.42 \%$ & $13.15 \%$ & $7.27 \%$ \\
\hline $\mathrm{CrO}$ & wt \% & $5.00 \%$ & $5.05 \%$ & $5.01 \%$ & $4.69 \%$ & $4.30 \%$ & $3.26 \%$ \\
\hline $\mathrm{Cr} \mathrm{O}_{3}$ & wt \% & $0.02 \%$ & $0.03 \%$ & $0.07 \%$ & $0.30 \%$ & $0.90 \%$ & $1.76 \%$ \\
\hline TOTAL: & wt \% & $100.00 \%$ & $100.00 \%$ & $100.00 \%$ & $100.00 \%$ & $100.00 \%$ & $100.00 \%$ \\
\hline TOTAL: & $\mathrm{g}$ & 76.03 & 89.12 & 99.71 & 120.19 & 140.19 & 158.74 \\
\hline Basicity & & 0.45 & 0.75 & 1.00 & 1.50 & 2.00 & 2.50 \\
\hline
\end{tabular}

\section{Page 62}


Table 27 (continued)

ALLOY

\begin{tabular}{|l|r|r|r|r|r|r|r|}
\hline Cr & wt $\%$ & $65.11 \%$ & $68.13 \%$ & $69.89 \%$ & $71.96 \%$ & $72.22 \%$ & $72.17 \%$ \\
\hline $\mathrm{Fe}$ & wt $\%$ & $24.36 \%$ & $25.39 \%$ & $26.06 \%$ & $27.00 \%$ & $27.55 \%$ & $27.77 \%$ \\
\hline $\mathrm{Si}$ & wt $\%$ & $10.54 \%$ & $6.47 \%$ & $4.04 \%$ & $1.04 \%$ & $0.23 \%$ & $0.06 \%$ \\
\hline TOTAL: & wt $\%$ & $100.00 \%$ & $100.00 \%$ & $100.00 \%$ & $100.00 \%$ & $100.00 \%$ & $100.00 \%$ \\
\hline TOTAL: & $\mathrm{g}$ & 83.97 & 73.58 & 68.29 & 62.31 & 59.71 & 58.44 \\
\hline
\end{tabular}

SOLID OXIDE

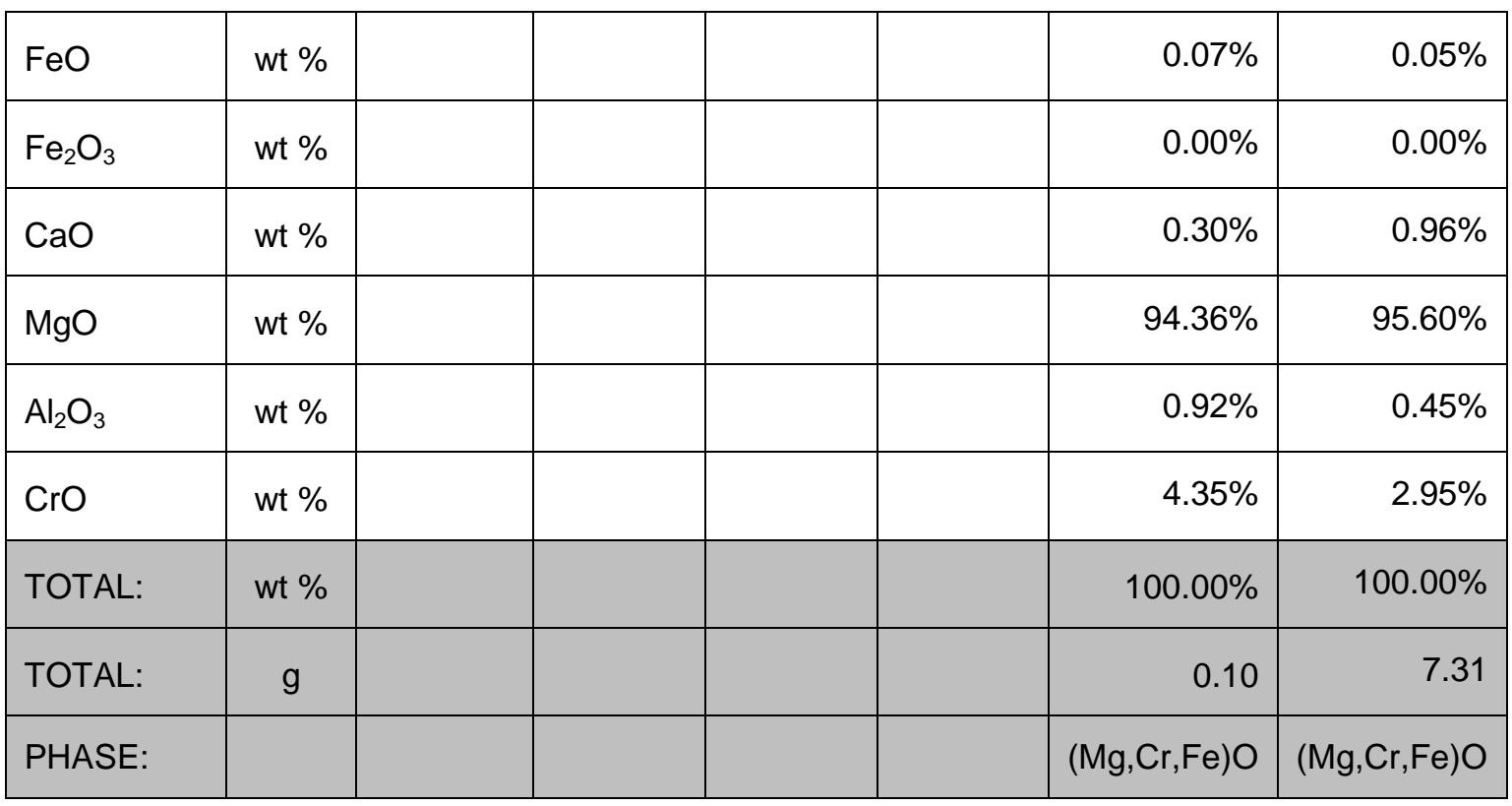

At a slag basicity of 2.5 , an $\mathrm{MgO}$-rich phase precipitated from the slag, thereby indicating that the slag is compatible with the magnesia lining.

The alloy silicon content decreases with an increase in the slag basicity. The reason for this is that, as more lime is added, the activity of $\mathrm{SiO}_{2}$ in the slag decreases. This promotes further reduction of the chromite with $\mathrm{Si}$ (to form $\mathrm{SiO}_{2}$ ). The specification of less than $1 \% \mathrm{Si}$ in the alloy is only achieved above a slag basicity of 1.5 .

No $\mathrm{Cr}(\mathrm{VI})$ is predicted to be present in any of the products. As mentioned, hexavalent chromium forms under highly oxidising conditions, which is not the case for this process. Although the model predicts that no gases will form, in reality, some metal vapour will be present due to the high arc temperatures, which can be above 10000 $\mathrm{K}$ (Jones, et al., 2011). 
No gases were present at equilibrium for the entire slag basicity range. The $\mathrm{Mg}$ content in the alloy was also close to zero (less than $0.0001 \%$ ).

\subsubsection{Slag Liquidus Temperature}

The modelling was done to determine the lowest temperature at which there are no solid oxides present in the slag. The slag liquidus temperature for different basicities is shown in Table 28 and Figure 27. The shaded area indicates where the slag liquidus temperature corresponds with the temperature range identified in Section 4.1 .

Table 28: Lime slag liquidus temperature for different basicities.

\begin{tabular}{|c|c|c|}
\hline Basicity & Liquidus $\mathrm{T}\left({ }^{\circ} \mathrm{C}\right)$ & Primary phase \\
\hline$(\mathrm{CaO}+\mathrm{MgO}) / \mathrm{SiO}_{2}$ & Lime slag & \\
\hline 0.75 & 1386 & $\begin{array}{l}\text { Forsterite } \\
\mathrm{Mg}_{2} \mathrm{SiO}_{4}\end{array}$ \\
\hline 1 & 1357 & $\begin{array}{l}\text { Forsterite } \\
\mathrm{Mg}_{2} \mathrm{SiO}_{4}\end{array}$ \\
\hline 1.5 & 1444 & $\begin{array}{c}\text { Spinel } \\
\mathrm{MgCr}_{2} \mathrm{O}_{4}, \mathrm{MgAl}_{2} \mathrm{O}_{4}\end{array}$ \\
\hline 2 & 1760 & $\begin{array}{c}\text { Periclase } \\
\mathrm{MgO}\end{array}$ \\
\hline 2.5 & 1929 & $\begin{array}{c}\text { Periclase } \\
\text { MgO }\end{array}$ \\
\hline
\end{tabular}

Page 64 


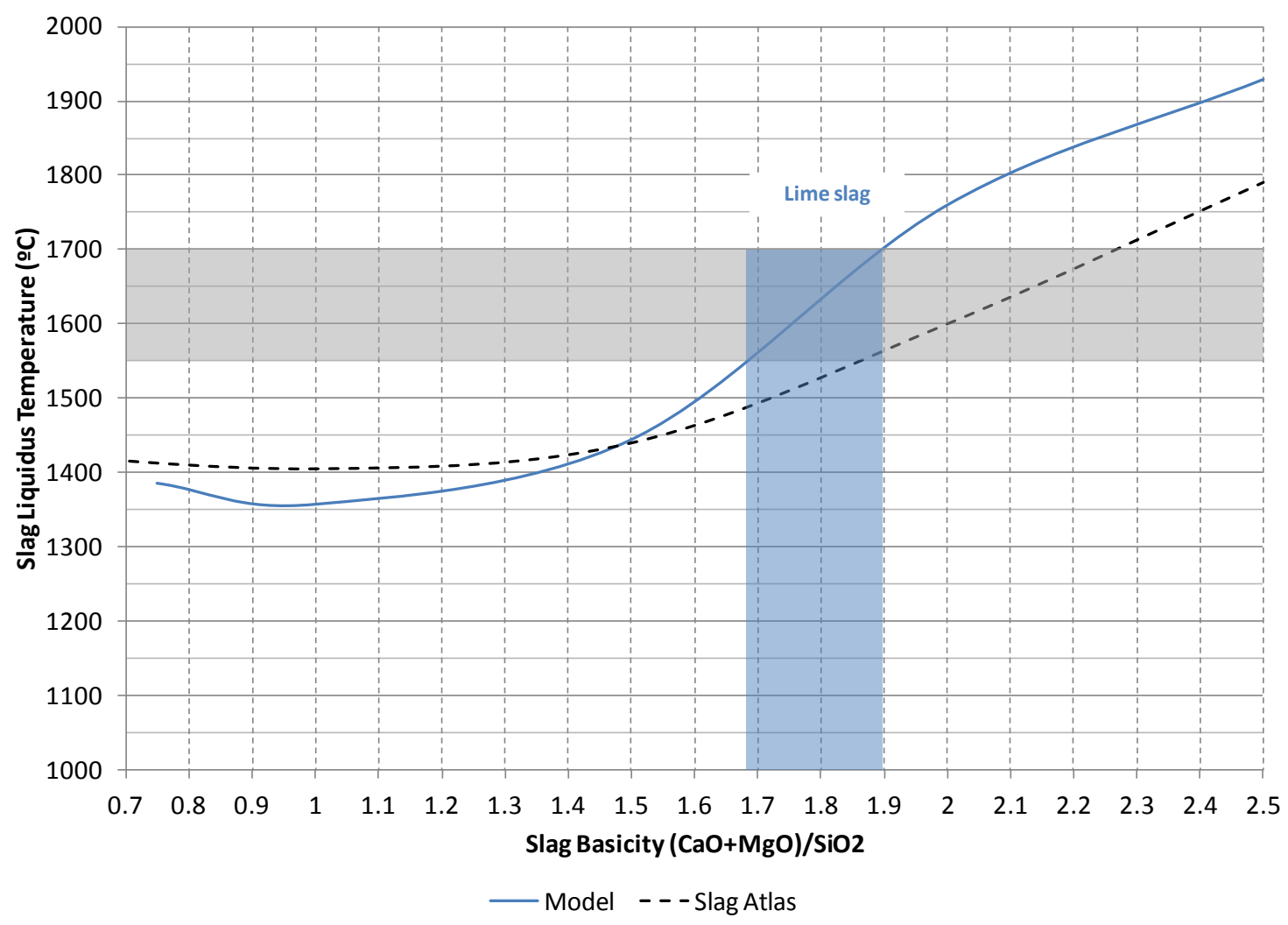

Figure 27: Liquidus temperature for lime slag.

The corresponding slag basicity is therefore 1.68 to 1.90 . The liquidus temperature estimates from the quaternary phase diagrams (Table 24) are also shown in Figure 27. There is some variation between the modelling results and that predicted by the phase diagrams, which indicates a basicity range of 1.87 to 2.27 for the same 1550 to $1700^{\circ} \mathrm{C}$ liquidus temperature range. This is indicative of the effect that minor components can have on the slag liquidus temperature. However, having selected a basicity window that was wide enough ensured that the ideal basicity range could be identified from the modelling results.

\subsubsection{Interaction between Refractory and Slag}

The interaction between the reaction products and the refractory bricks were also modelled. This is essential for the ability of the furnace to contain the process in periods where a freeze lining is lost.

The commercial furnace will operate with a slag freeze lining on the refractory hot face. This is achieved by circulating water through cooling water channels or in a water film on the outside of the furnace shell. However, at times the freeze lining may be lost when it breaks off from the refractories due to thermal shock, or it may be worn away in periods where the operating temperature exceeds the liquidus temperature. In the time that it takes to re-establish the freeze lining, the refractory bricks will be exposed to superheated slag. The reaction between the refractory 
materials and the slag needs to be evaluated to determine the ability of the refractory to withstand slag attack.

Modelling the interface between the slag and refractory is complex, as it is effectively a layer with a thickness of one molecule. This also does not take into consideration the effect of stirring, which continually replaces the slag on the interface with bulk slag.

A more sensible way of modelling the potential refractory wear is by considering the maximum solubility of the solid magnesia refractory in the slag. The equilibrium slag products from the modelling was incrementally added (in new models) to $100 \mathrm{~g}$ of magnesia refractory. The liquid slag and solid $\mathrm{MgO}$ were then plotted as a function of the slag addition. The modelling was done at a temperature of $1750^{\circ} \mathrm{C}$. The liquid slag addition limit was chosen to be $200 \mathrm{~g}$, as the maximum amount of slag in contact with the refractory is not expected to exceed the mass of solid magnesia more than once.

As the amount of slag added to the $100 \mathrm{~g}$ of magnesia refractory increases, the total slag in the system should increase by the same amount if there is no reaction between the slag and refractory. This indicates that the refractory is not absorbed into the slag and remains solid. This scenario is indicated by a dashed line in Figure 28, referred to as the Stability Limit. Any line above this indicates that some of the refractory has dissolved into the slag, as the slag mass is larger than that of the slag added to the system. Similarly, lines below the Stability Limit line indicate that some of the slag will solidify at the process conditions.

The data from Figure 28 indicates that the slag line corresponds with the Stability Limit line at a slag basicity of 1.82 . For a basicity higher than this, the refractory is expected to be stable. 


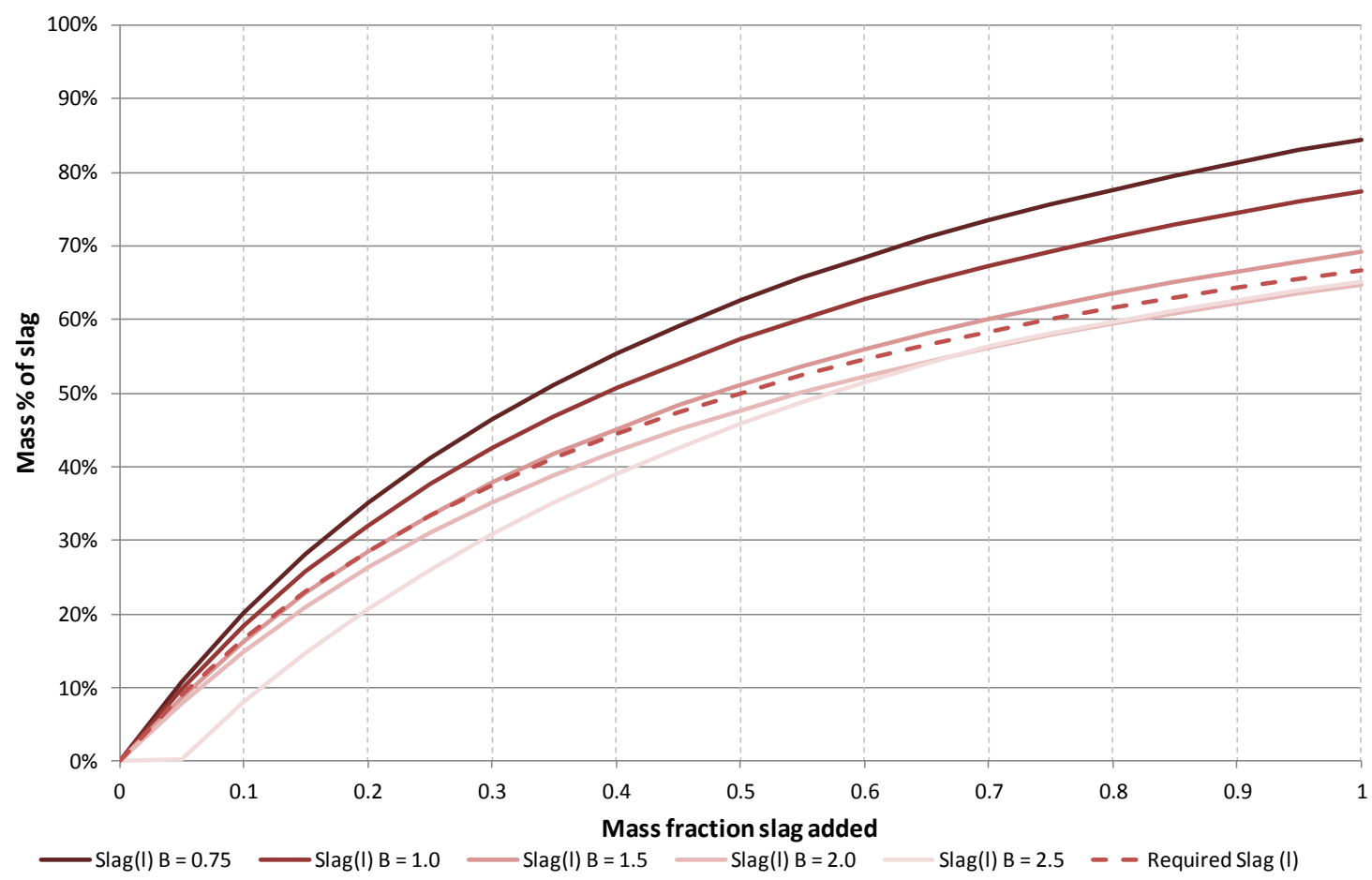

Figure 28: Slag as percentage of mass for all phases for increasing slag additions for slag basicities of 0.75, 1.0, 1.5, 2.0 and 2.5 (lime slag, MgO refractory) at $1750^{\circ} \mathrm{C}$.

However, it may happen that $\mathrm{MgO}$ from the magnesia refractory is dissolved in the slag, while other oxides precipitate from the slag. The representation in Figure 28 is therefore not sufficient for evaluating the performance of the refractory system in contact with the slag.

The amount of solid $\mathrm{MgO}$ remaining in the system would be a good indication of adequate performance, as this indicates that the slag is saturated with $\mathrm{MgO}$ and will not take $\mathrm{MgO}$ further into solution. The phase percentage of solid $\mathrm{MgO}$ is indicated as a function of the slag addition fraction in Figure 29. 


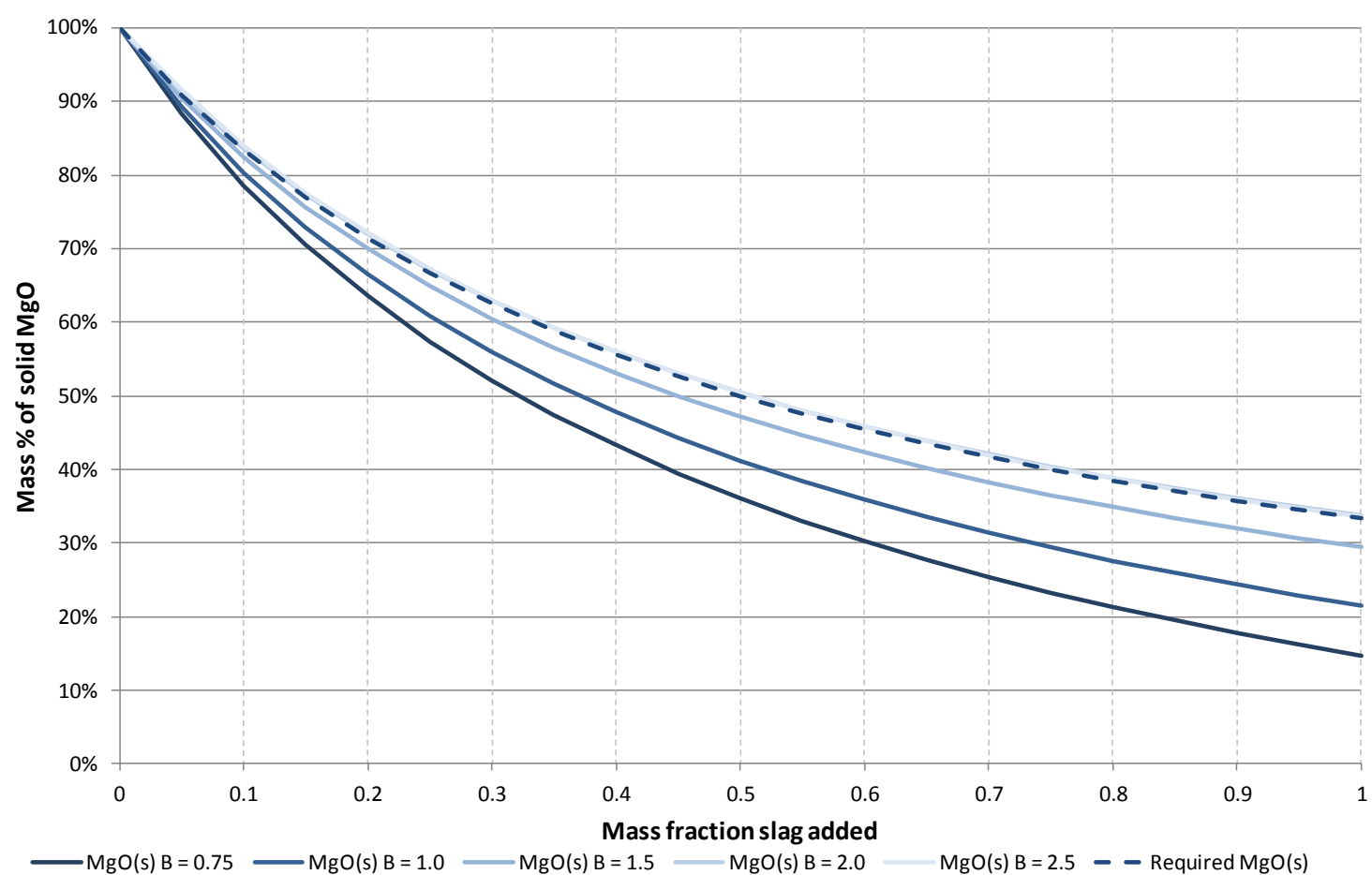

Figure 29: Solid MgO as percentage of mass for all phases for increasing slag additions for slag basicities of 0.75, 1.0, 1.5, 2.0 and 2.5 (lime slag, MgO refractory) at $1750^{\circ} \mathrm{C}$.

The amount of solid $\mathrm{MgO}$ required, as a percentage of total mass for all phases, is indicated as a dotted line in Figure 29. Lines below this line indicate that some MgO has dissolved into the slag. Note that the lines for basicities of 2.0 and 2.5 overlap the dotted line.

The solid $\mathrm{MgO}$ line coincides with the dotted line at a slag basicity of 1.99 . This is consistent with the data in Table 27, where a small amount of solid MgO is present at a slag basicity of 2.0 and rapidly increases at higher basicities. The slag basicity target of 1.99, derived from Figure 29, is slightly higher than the basicity of 1.82 derived from Figure 28. An explanation of what these two values mean follows.

At a slag basicity below 1.82, the slag will react with the magnesia refractory, resulting in an increase in the slag mass. Between a slag basicity of 1.82 and 1.99, the slag will still react with the magnesia refractory and cause the $\mathrm{MgO}$ content in the slag to increase. However, $\mathrm{Al}_{2} \mathrm{O}_{3}$ and $\mathrm{CrO}_{x}$ will precipitate from the slag as spinel (together with some $\mathrm{MgO}$ ) (Table 28), resulting in a net decrease in the liquid slag mass. Above a slag basicity of 1.99 , the slag will no longer react with $\mathrm{MgO}$ in the magnesia.

In practice, operating between these basicity limits should not prove to be problematic, as oxides that precipitate from the slag would tend to accumulate at the refractory hot phase, providing that the slag bath is not excessively turbulent. Using a 
target basicity in the middle of this range for the raw material analysis used in this study would therefore be a suitable operating set point. Allowance would obviously need to be made for variability in the ore composition.

\subsubsection{Doloma Refractories, Lime Slag}

\subsubsection{Reaction Products}

The reaction products are the same as in Section 4.5.1, as the raw materials and products used in the models were the same.

\subsubsection{Slag Liquidus Temperature}

The slag liquidus temperature is the same as in Section 4.5.1, as the raw materials and products used in the models were the same.

\subsubsection{Interaction between Refractory and Slag}

The reaction products for different slag additions were evaluated for the four process variations identified. The modelling was done similar to that of the process using a lime flux, where slag was introduced to the refractories in small increments and the reaction products identified.

As before, this modelling indicates how the slag would react with the refractories, should the freeze lining be lost for whatever reason. The same evaluation criteria were used for each of the processes as was used for the system using lime as a flux, namely the total slag as a function of the slag added, as well as the total basic oxides ( $\mathrm{MgO}$ and $\mathrm{CaO}$ ), compared to the starting mass of refractory. Again, the stability limits are indicated with dotted lines. 


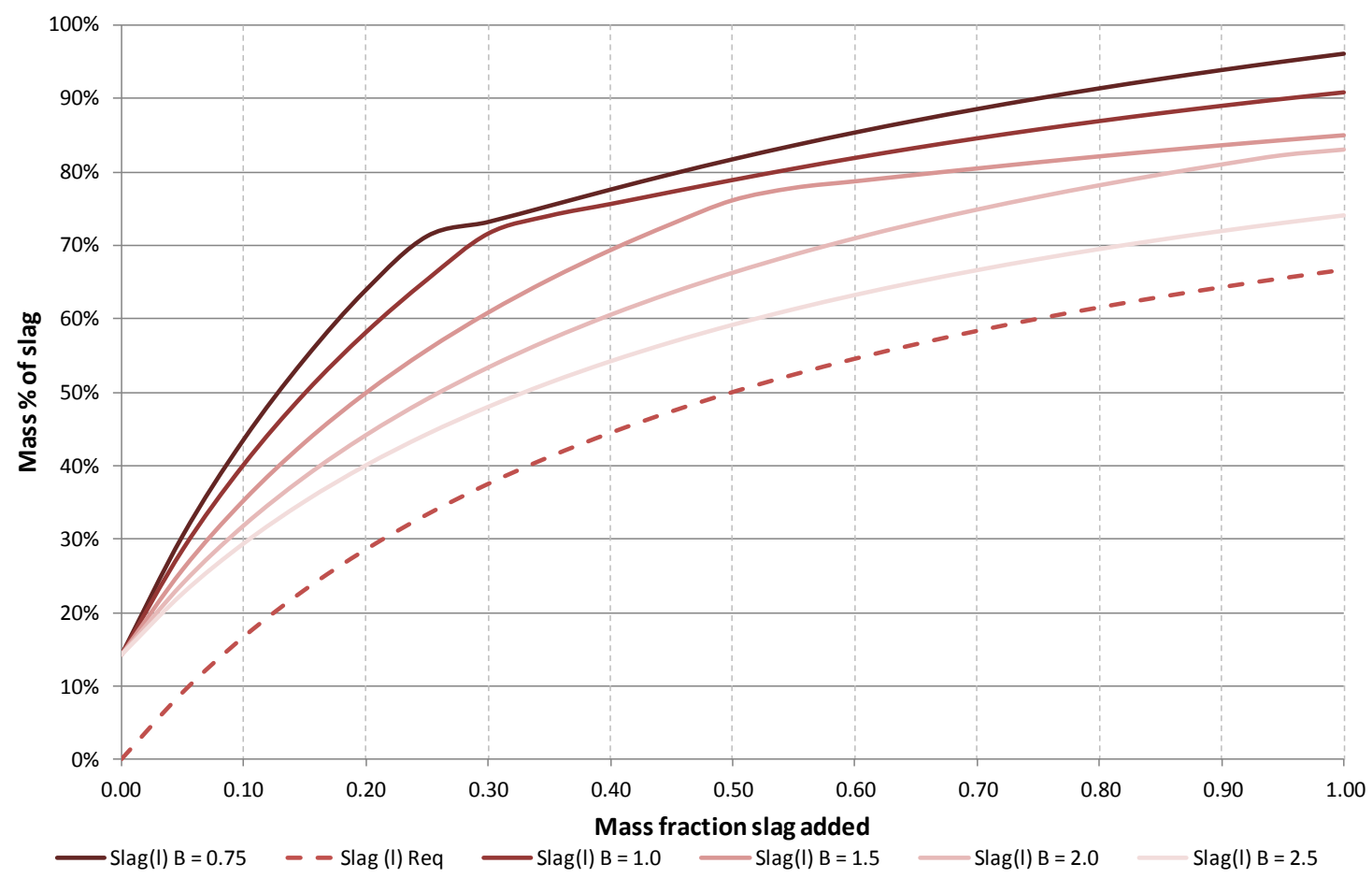

Figure 30: Slag as percentage of mass of all phases for increasing slag additions for slag basicities of 0.75, 1.0, 1.5, 2.0 and 2.5 (doloma refractory, lime slag) at $1750^{\circ} \mathrm{C}$.

Although there is some improvement with an increase in the basicity, the slag lines are above the stability limit for the entire range of basicities analysed (Figure 30). This indicates that some of the refractory has reacted with and dissolved in the slag. Also, more than $14 \%$ of the refractory melts at $1750^{\circ} \mathrm{C}$, even with no slag added to the system (as evidenced at the point of 0.00 mass fraction slag added in Figure 30). The refractory will therefore be prone to thermal degradation if no freeze lining is present. 


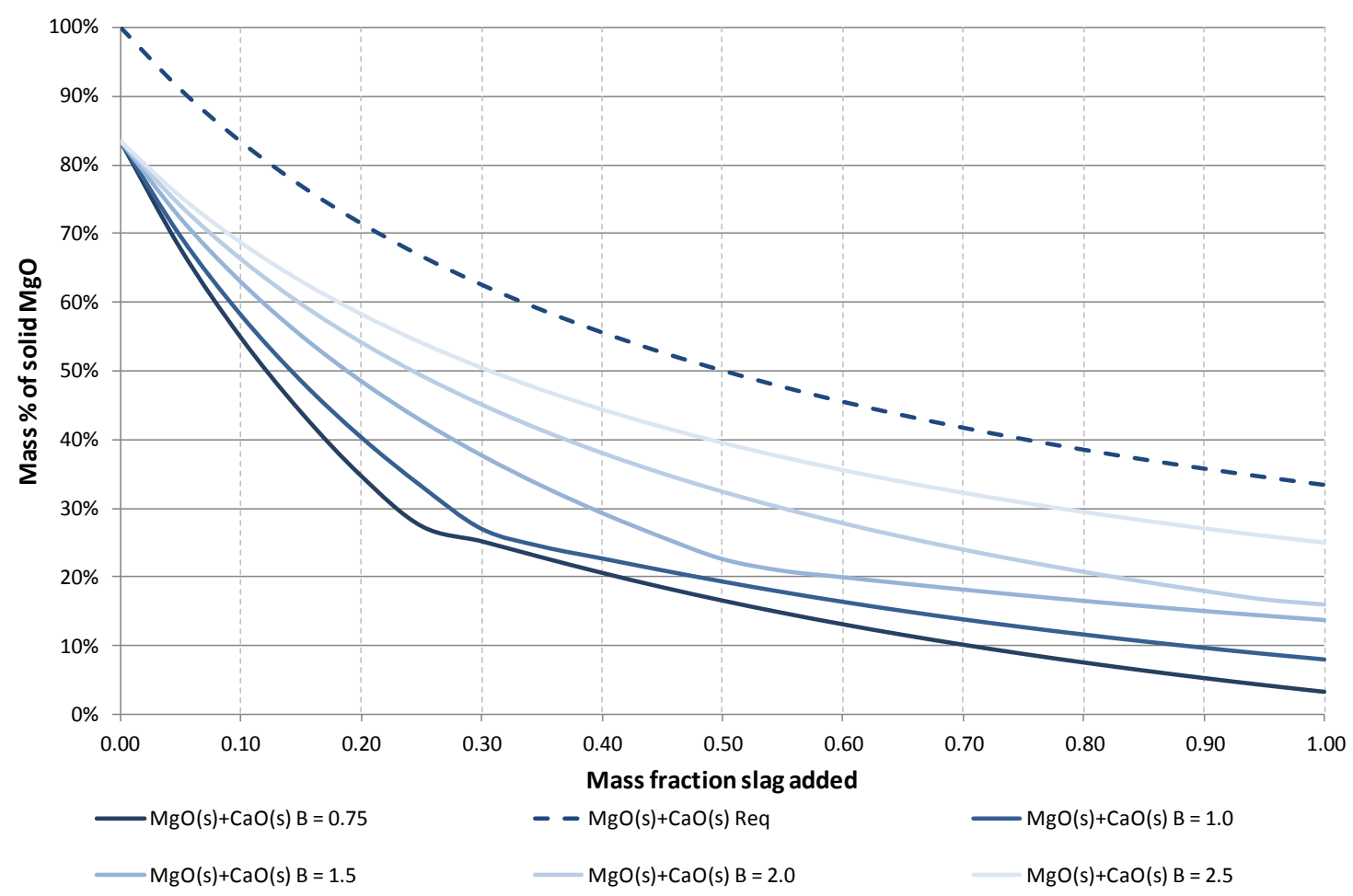

Figure 31: Solid $\mathrm{MgO}+\mathrm{CaO}$ as percentage of mass for all phases for increasing slag additions for slag basicities of 0.75, 1.0, 1.5, 2.0 and 2.5 (doloma refractory, lime slag) at $1750^{\circ} \mathrm{C}$.

The total solid $\mathrm{MgO}+\mathrm{CaO}$ is less than the starting refractory mass $(100 \mathrm{~g})$ for all basicities analysed (Figure 31). This is in agreement with Figure 30. From these results it is clear that the system does not perform as well as with the lime flux.

\subsubsection{Doloma Refractories, Doloma Slag}

\subsubsection{Reaction Products}

$100 \mathrm{~g}$ of concentrate was again used as the basis for the calculations. The FeSiCr addition was changed to get a total slag chrome oxide content of $5-6 \%$, expressed as $\mathrm{Cr}_{2} \mathrm{O}_{3}$. The doloma addition was selected to get a slag basicity of $0.75,1.0,1.5,2.0$ and 2.5 .

As discussed earlier, a slag liquidus temperature of $1550-1700^{\circ} \mathrm{C}$ was targeted in order to be compatible with the process temperature which, in turn, was selected based on the alloy liquidus temperature.

The reaction products for the different basicities, using a doloma flux, are shown in Table 29. 
Table 29: Reaction products from thermochemical modelling, doloma flux, temperature $=1750^{\circ} \mathrm{C}$.

\section{FEED}

\begin{tabular}{|l|r|r|r|r|r|r|}
\hline $\begin{array}{l}\text { Target } \\
\text { Basicity }\end{array}$ & & 0.75 & 1.00 & 1.50 & 2.00 & 2.50 \\
\hline Concentrate & $\mathrm{g}$ & 100.0 & 100.0 & 100.0 & 100.0 & 100.0 \\
\hline FeSiCr & $\mathrm{g}$ & 50.0 & 45.0 & 40.0 & 38.0 & 37.0 \\
\hline Doloma & $\mathrm{g}$ & 14.3 & 26.0 & 55.0 & 124.0 & 182.0 \\
\hline
\end{tabular}

\section{SLAG}

\begin{tabular}{|l|r|r|r|r|r|r|}
\hline $\mathrm{Al}_{2} \mathrm{O}_{3}$ & wt \% & $12.24 \%$ & $10.99 \%$ & $9.13 \%$ & $7.85 \%$ & $7.06 \%$ \\
\hline $\mathrm{SiO}_{2}$ & wt $\%$ & $47.12 \%$ & $42.02 \%$ & $34.34 \%$ & $29.09 \%$ & $25.04 \%$ \\
\hline $\mathrm{CaO}$ & $w t \%$ & $9.14 \%$ & $14.44 \%$ & $24.35 \%$ & $44.82 \%$ & $55.04 \%$ \\
\hline $\mathrm{FeO}$ & $w t \%$ & $0.05 \%$ & $0.05 \%$ & $0.04 \%$ & $0.06 \%$ & $0.11 \%$ \\
\hline $\mathrm{MgO}$ & wt \% & $26.31 \%$ & $27.52 \%$ & $27.16 \%$ & $13.22 \%$ & $7.49 \%$ \\
\hline $\mathrm{CrO}$ & wt $\%$ & $5.09 \%$ & $4.86 \%$ & $4.45 \%$ & $4.09 \%$ & $3.39 \%$ \\
\hline $\mathrm{Cr}_{2} \mathrm{O}_{3}$ & wt $\%$ & $0.05 \%$ & $0.13 \%$ & $0.52 \%$ & $0.86 \%$ & $1.87 \%$ \\
\hline TOTAL: & wt $\%$ & $100.00 \%$ & $100.00 \%$ & $100.00 \%$ & $100.00 \%$ & $100.00 \%$ \\
\hline TOTAL: & $\mathrm{g}$ & 90.50 & 102.19 & 126.54 & 153.74 & 182.59 \\
\hline Basicity & & 0.75 & 1.00 & 1.50 & 2.00 & 2.50 \\
\hline
\end{tabular}

Page 72 
Table 29 (continued)

ALLOY

\begin{tabular}{|l|r|r|r|r|r|r|}
\hline $\mathrm{Cr}$ & wt $\%$ & $67.80 \%$ & $69.33 \%$ & $70.13 \%$ & $67.61 \%$ & $65.17 \%$ \\
\hline $\mathrm{Fe}$ & wt $\%$ & $25.84 \%$ & $26.89 \%$ & $28.88 \%$ & $32.18 \%$ & $34.78 \%$ \\
\hline $\mathrm{Si}$ & wt $\%$ & $6.36 \%$ & $3.77 \%$ & $0.99 \%$ & $0.21 \%$ & $0.05 \%$ \\
\hline TOTAL: & wt $\%$ & $100.00 \%$ & $100.00 \%$ & $100.00 \%$ & $100.00 \%$ & $100.00 \%$ \\
\hline TOTAL: & $\mathrm{g}$ & 73.80 & 68.81 & 63.71 & 61.73 & 60.85 \\
\hline
\end{tabular}

\section{SOLID OXIDE}

\begin{tabular}{|c|c|c|c|c|}
\hline $\mathrm{FeO}$ & wt $\%$ & $0.08 \%$ & $0.08 \%$ & $0.08 \%$ \\
\hline $\mathrm{Fe}_{2} \mathrm{O}_{3}$ & wt $\%$ & $0.00 \%$ & $0.00 \%$ & $0.00 \%$ \\
\hline $\mathrm{CaO}$ & wt $\%$ & $0.06 \%$ & $0.30 \%$ & $0.91 \%$ \\
\hline $\mathrm{MgO}$ & wt $\%$ & $93.93 \%$ & $94.46 \%$ & $95.30 \%$ \\
\hline $\mathrm{Al}_{2} \mathrm{O}_{3}$ & wt $\%$ & $1.05 \%$ & $0.93 \%$ & $0.47 \%$ \\
\hline $\mathrm{CrO}$ & wt $\%$ & $4.88 \%$ & $4.23 \%$ & $3.24 \%$ \\
\hline TOTAL: & wt $\%$ & $100.00 \%$ & $100.00 \%$ & $100.00 \%$ \\
\hline TOTAL: & $g$ & 4.75 & 46.53 & 75.56 \\
\hline PHASE: & & $(\mathrm{Mg}, \mathrm{Cr}, \mathrm{Fe}) \mathrm{O}$ & $(\mathrm{Mg}, \mathrm{Cr}, \mathrm{Fe}) \mathrm{O}$ & $(\mathrm{Mg}, \mathrm{Cr}, \mathrm{Fe}) \mathrm{O}$ \\
\hline
\end{tabular}

The alloy chromium content varies somewhat with a change in basicity, with a local maximum at a slag basicity of approximately 1.5 .

The alloy silicon content again decreases with an increase in the slag basicity. As mentioned earlier, the reason for this is that, as more doloma is added, the activity of $\mathrm{SiO}_{2}$ in the slag decreases. This creates the driving force for the formation of $\mathrm{SiO}_{2}$.

From the data, an MgO-rich phase should start precipitating above a slag basicity of 1.41. The slag is therefore saturated in $\mathrm{MgO}$ above a slag basicity of 1.41 .

As for the lime flux system, no $\mathrm{Cr}(\mathrm{VI})$ is predicted to be present.

\subsubsection{Slag Liquidus Temperature}

As was the case for the process using lime as the flux, the slag needs to have a liquidus temperature of between 1550 and $1700^{\circ} \mathrm{C}$. 
The liquidus temperatures over the range of basicities for the doloma slag, as well as the comparative liquidus temperature estimates from the quaternary phase diagrams (Table 24) in the Slag Atlas, are shown in Figure 32. The doloma slag liquidus temperature is also compared with that of the lime slag in Figure 33. The allowable liquidus temperature ranges, as well as the corresponding slag basicities are indicated in the shaded areas on the graphs.

Table 30: Doloma slag liquidus temperature for different basicities.

\begin{tabular}{|c|c|c|}
\hline Basicity & Liquidus T (으) & Primary phase \\
\hline$(\mathrm{CaO}+\mathrm{MgO}) / \mathrm{SiO}_{2}$ & Doloma slag & \\
\hline 0.75 & 1448 & $\begin{array}{c}\text { Forsterite } \\
\mathrm{Mg}_{2} \mathrm{SiO}_{4}\end{array}$ \\
\hline 1 & 1505 & $\begin{array}{c}\text { Forsterite } \\
\mathrm{Mg}_{2} \mathrm{SiO}_{4}\end{array}$ \\
\hline 1.5 & 1914 & $\begin{array}{c}\text { Periclase } \\
\text { MgO }\end{array}$ \\
\hline 2 & 2262 & $\begin{array}{c}\text { Periclase } \\
\text { MgO }\end{array}$ \\
\hline 2.5 & 2323 & $\begin{array}{c}\text { Periclase } \\
\text { MgO }\end{array}$ \\
\hline
\end{tabular}




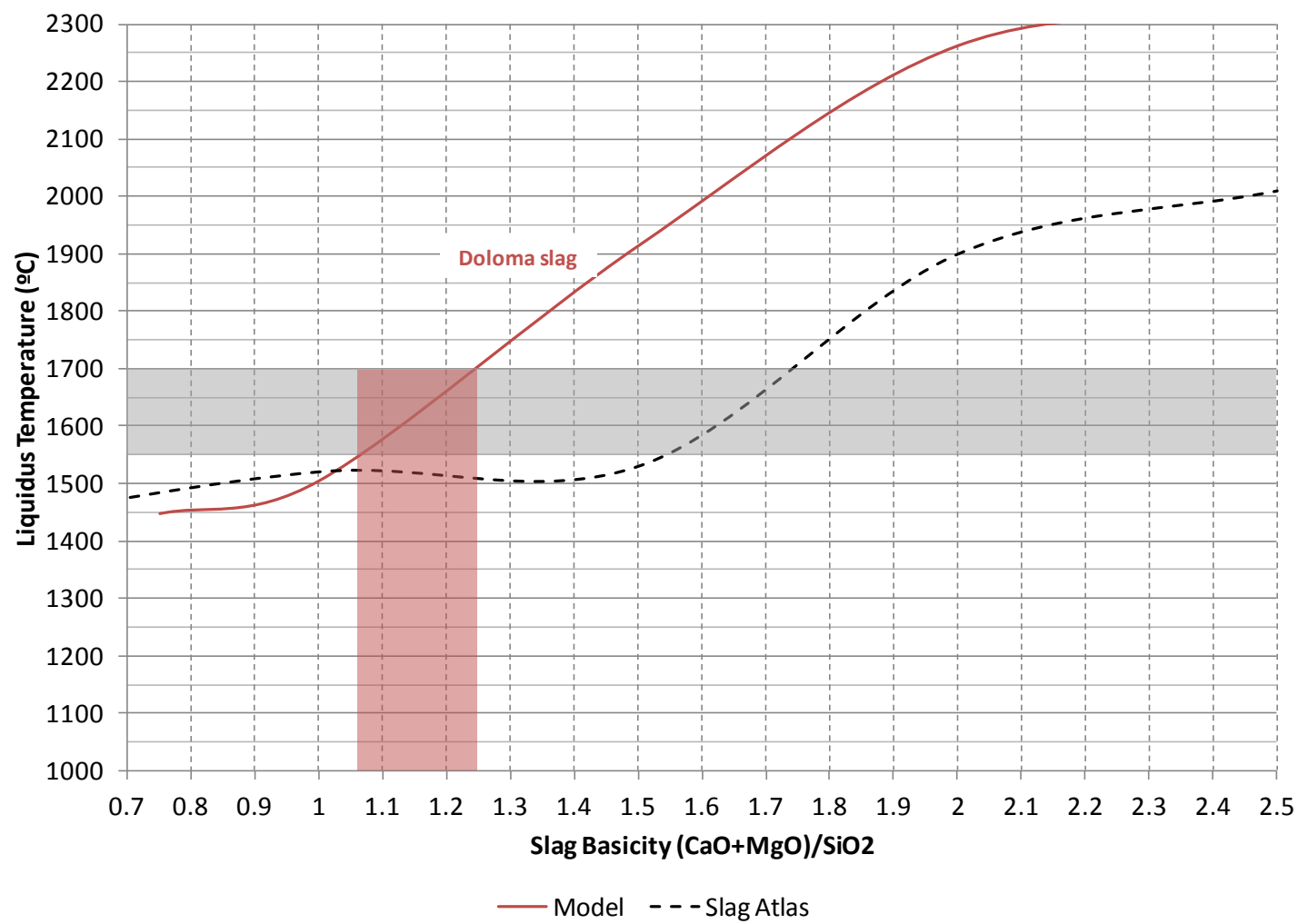

Figure 32: Liquidus temperatures for doloma slag.

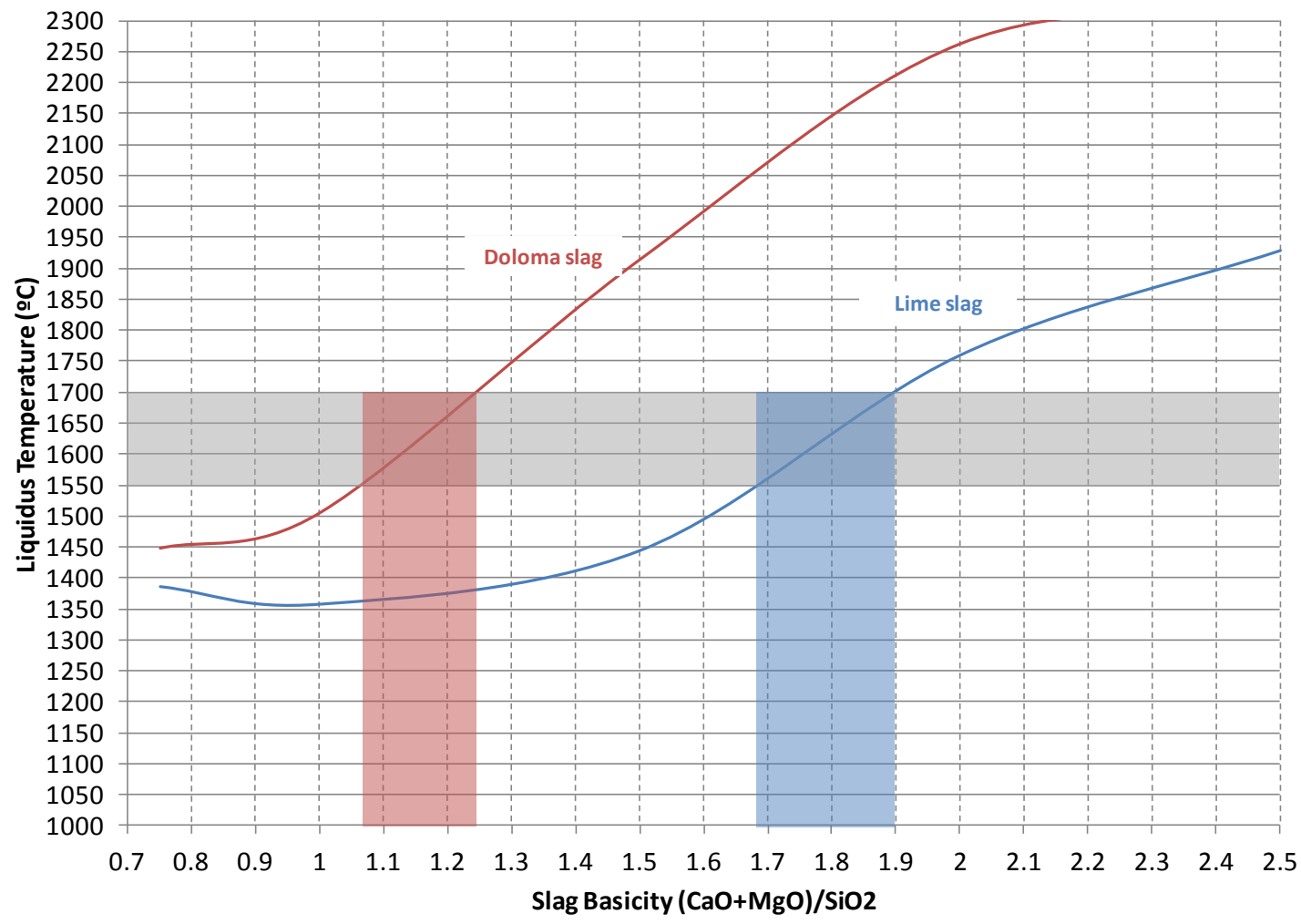

Figure 33: Liquidus temperatures for lime and doloma slag.

\section{Page 75}

(C) University of Pretoria 
The doloma slag basicity range that would yield a suitable liquidus temperature is therefore 1.07 to 1.23 . As with the lime slag, there is a significant difference between the modelling results and that predicted from the quaternary phase diagrams. However, having selected a basicity window that was wide enough ensured that the ideal basicity range could be identified from the modelling results.

\subsubsection{Interaction between Refractory and Slag}

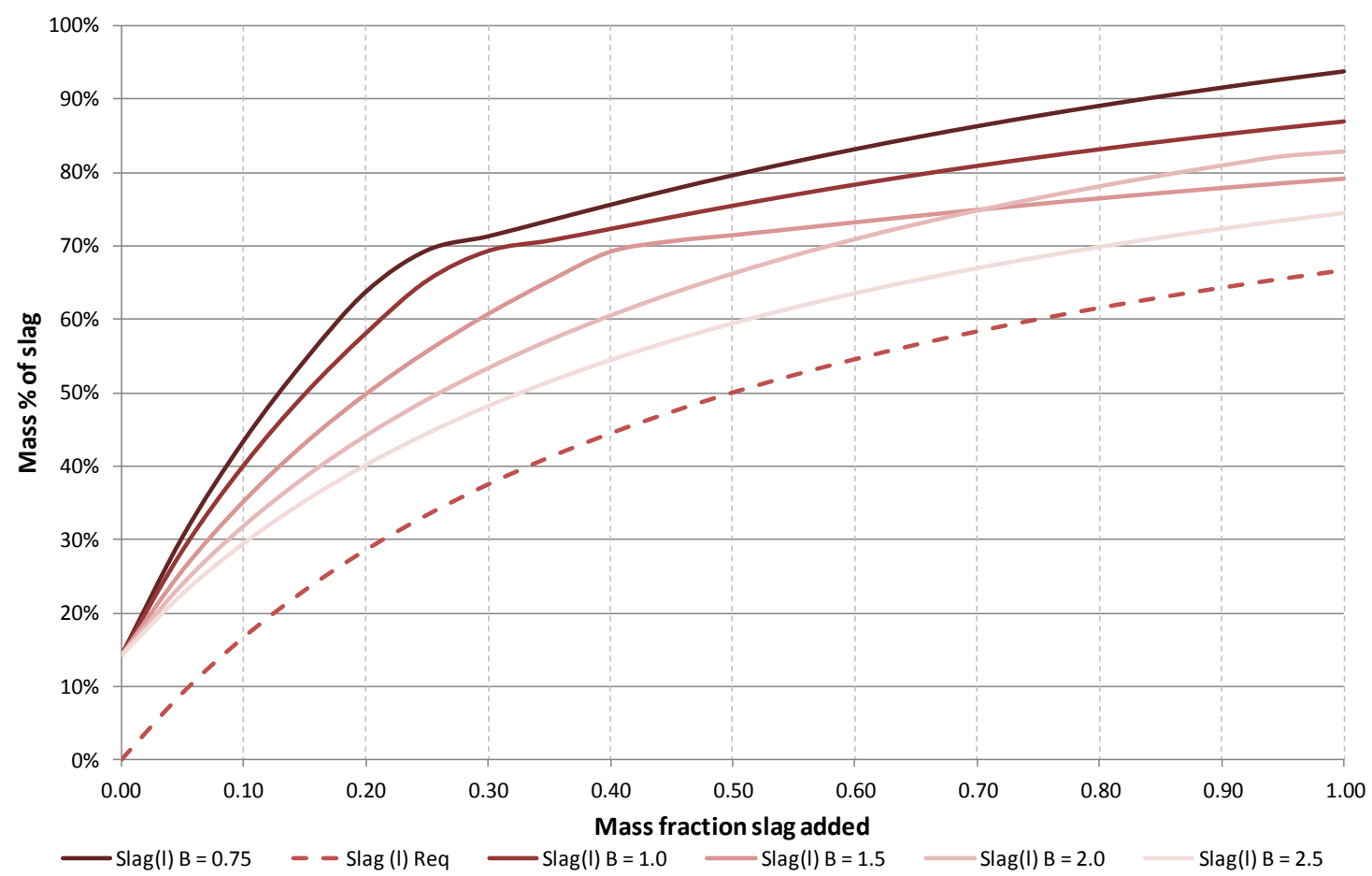

Figure 34: Slag as percentage of mass of all phases for increasing slag additions for slag basicities of $0.75,1.0,1.5,2.0$ and 2.5 (doloma refractory, doloma slag) at $1750^{\circ} \mathrm{C}$. 


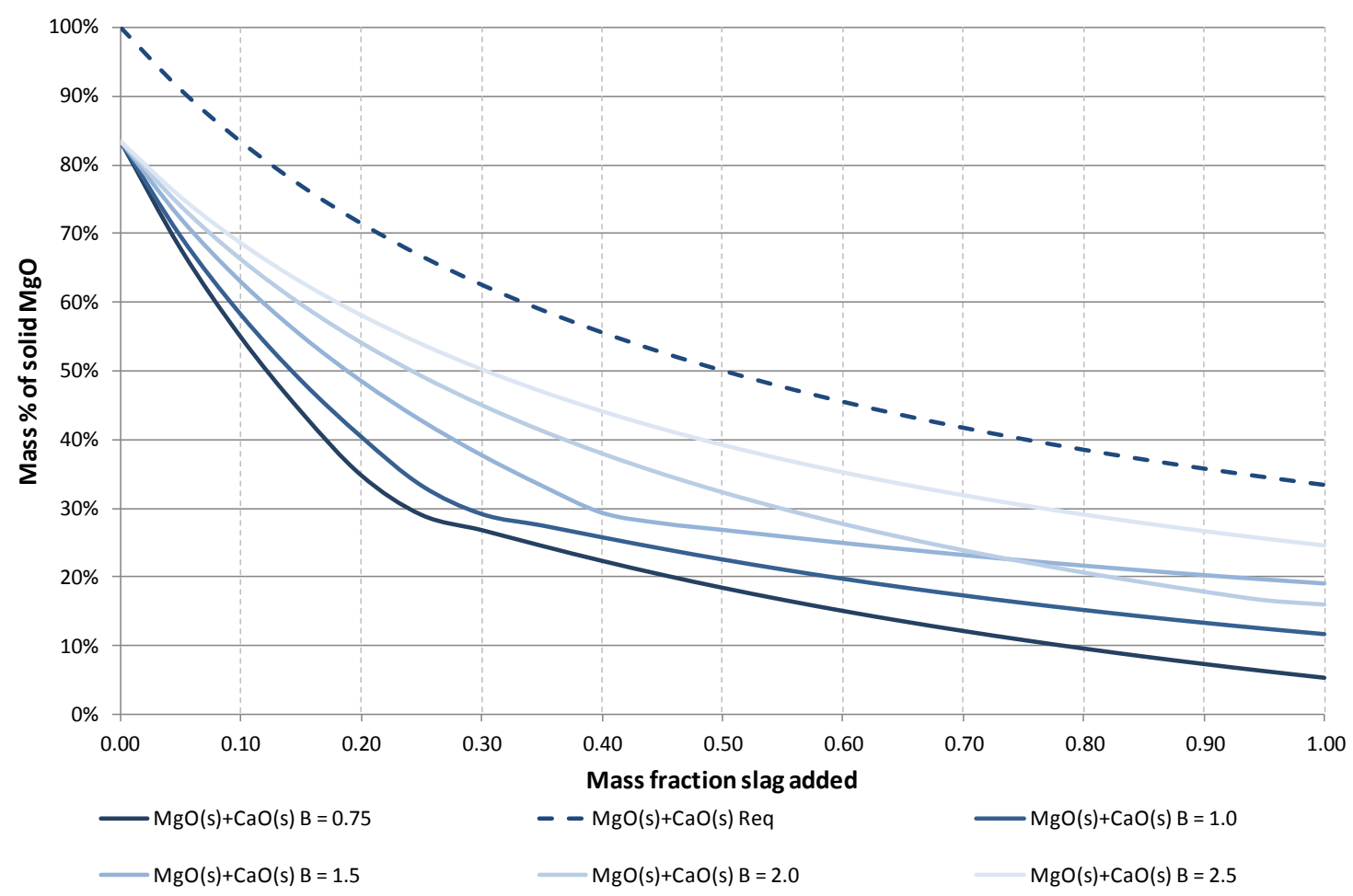

Figure 35: Solid $\mathrm{MgO}+\mathrm{CaO}$ as percentage of mass for all phases for increasing slag additions for slag basicities of 0.75, 1.0, 1.5, 2.0 and 2.5 (doloma refractory, doloma slag) at $1750^{\circ} \mathrm{C}$.

The performance of the doloma slag, doloma refractory system is slightly improved from the lime slag, doloma refractory system, especially at lower basicities (Figure 34 and Figure 35). At a slag basicity of 2.0 and higher there is hardly any distinction between the two systems. As with the lime slag, doloma refractory system, the performance is much worse than for the system using lime as a flux.

\subsubsection{Magnesia Refractories, Doloma Slag}

\subsubsection{Reaction Products}

The reaction products are the same as in Section 4.5.3, as the same raw materials and products were used in the modelling.

\subsubsection{Slag Liquidus Temperature}

The slag liquidus temperature is the same as in Section 4.5.3, as the same raw materials and products were used in the modelling. 


\subsubsection{Interaction between Refractory and Slag}

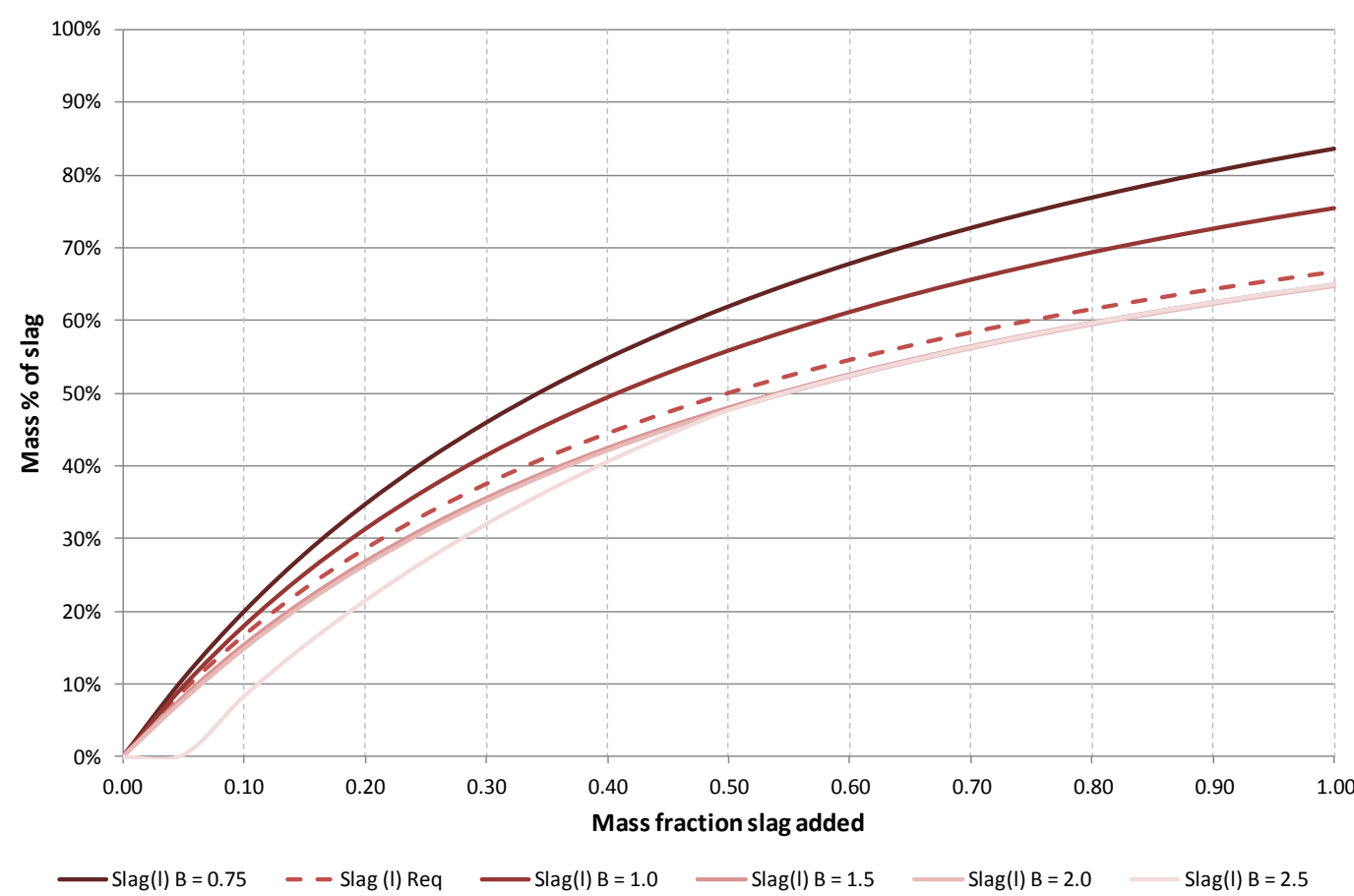

Figure 36: Slag as percentage of mass of all phases for increasing slag additions for slag basicities of 0.75, 1.0, 1.5, 2.0 and 2.5 (doloma slag, MgO refractory) at $1750^{\circ} \mathrm{C}$.

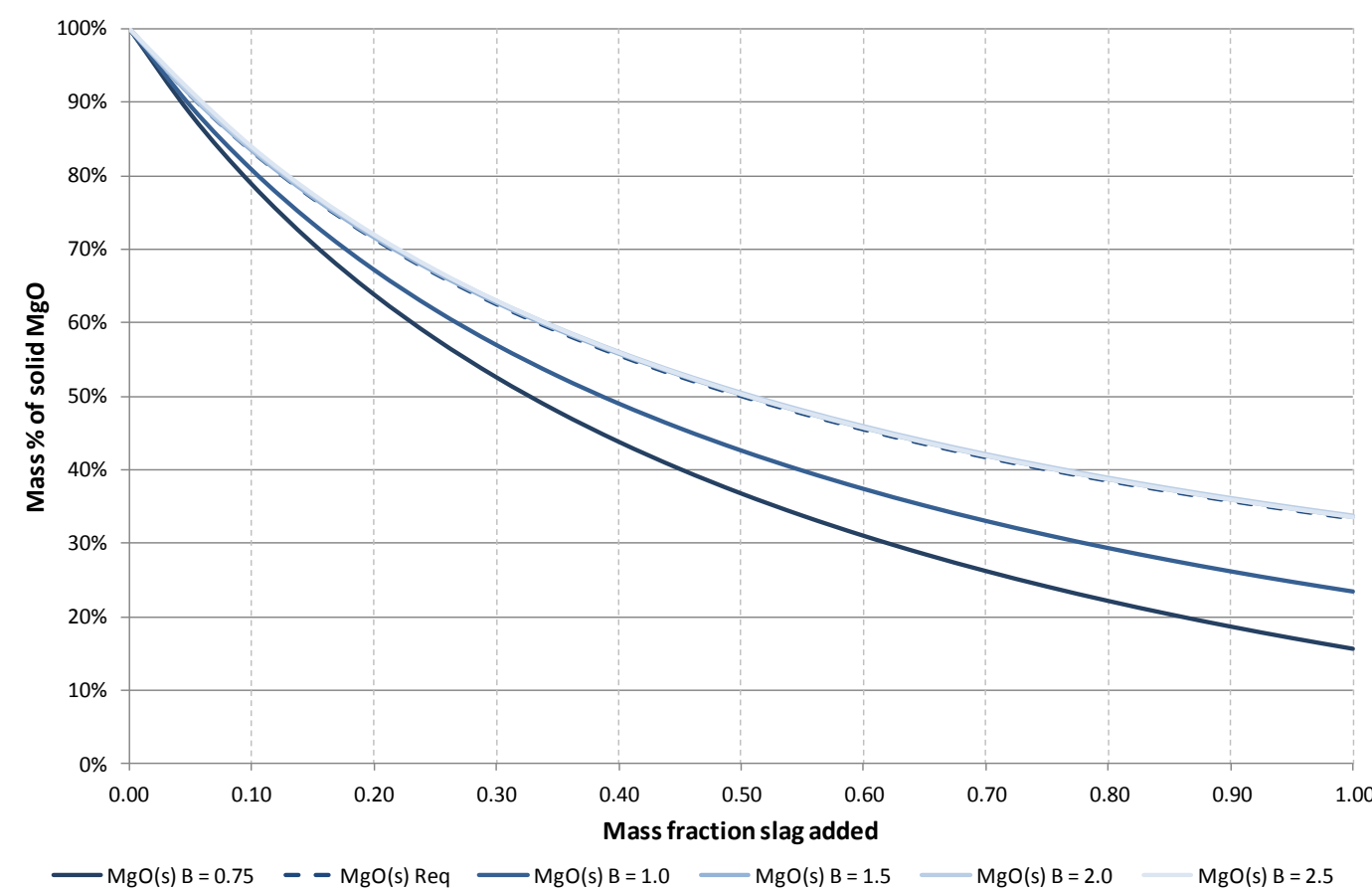

Figure 37: Solid $\mathrm{MgO}+\mathrm{CaO}$ as percentage of mass for all phases for increasing slag additions for slag basicities of 0.75, 1.0, 1.5, 2.0 and 2.5 (doloma slag, MgO refractory) at $1750^{\circ} \mathrm{C}$.

\section{Page 78}


The slag formation shows an improvement to that of the standard process (lime slag, $\mathrm{MgO}$ refractory). A slag with basicity of approximately 1.4 is already below the stability line, compared to the 1.82 for the lime flux system. This means that no magnesia will react with the slag at a basicity above 1.4 .

For this system, as for the magnesia refractory, lime slag system, the solid MgO was evaluated, as this is the primary component of the refractory used. Figure 37 shows the solid $\mathrm{MgO}$ lines to be above the initial $\mathrm{MgO}$ required (original refractory in system) for basicities from 1.5 and above (lines overlap on figure). This again is an improvement to the process with lime as the flux.

However, for a slag with a basicity of 1.4 , the liquidus temperature is approximately $1810^{\circ} \mathrm{C}$. To ensure that the slag can be tapped and handled without difficulty, the process operating temperature should therefore be increased, which would result in thermal damage to the refractories.

\subsubsection{Alumina Refractory, Quartz Slag}

\subsubsection{Reaction Products}

The reaction products for different basicities for varying quantities of quartz addition are shown in Table 31. Unlike the cases for the lime and doloma slags, the basicity target was not known, as there was no existing process to compare the slag to. Instead, the quartz addition was increased incrementally. 
Table 31: Reaction products from thermochemical modelling, quartz flux, temperature $=1750^{\circ} \mathrm{C}$.

FEED

\begin{tabular}{|l|r|r|r|r|r|r|r|}
\hline Concentrate & $\mathrm{g}$ & 100.0 & 100.0 & 100.0 & 100.0 & 100.0 & 100.0 \\
\hline FeSiCr & $\mathrm{g}$ & 62.0 & 65.0 & 65.0 & 64.0 & 63.0 & 60.0 \\
\hline Quartz & $\mathrm{g}$ & 100.0 & 40.0 & 30.0 & 20.0 & 10.0 & \\
\hline
\end{tabular}

\section{SLAG}

\begin{tabular}{|l|r|r|r|r|r|r|r|}
\hline $\mathrm{Al}_{2} \mathrm{O}_{3}$ & wt \% & $6.66 \%$ & $9.30 \%$ & $10.19 \%$ & $11.27 \%$ & $12.62 \%$ & $14.32 \%$ \\
\hline $\mathrm{SiO}_{2}$ & wt \% & $76.95 \%$ & $69.62 \%$ & $67.15 \%$ & $64.08 \%$ & $60.47 \%$ & $55.76 \%$ \\
\hline $\mathrm{CaO}$ & wt \% & $0.21 \%$ & $0.30 \%$ & $0.33 \%$ & $0.36 \%$ & $0.41 \%$ & $0.46 \%$ \\
\hline $\mathrm{FeO}$ & wt \% & $0.08 \%$ & $0.07 \%$ & $0.07 \%$ & $0.07 \%$ & $0.06 \%$ & $0.06 \%$ \\
\hline $\mathrm{MgO}$ & wt \% & $11.40 \%$ & $15.82 \%$ & $17.34 \%$ & $19.18 \%$ & $21.47 \%$ & $24.37 \%$ \\
\hline $\mathrm{CrO}$ & wt \% & $4.68 \%$ & $4.88 \%$ & $4.91 \%$ & $5.04 \%$ & $4.95 \%$ & $5.00 \%$ \\
\hline $\mathrm{Cr} \mathrm{O}_{3}$ & wt \% & $0.01 \%$ & $0.01 \%$ & $0.01 \%$ & $0.01 \%$ & $0.01 \%$ & $0.02 \%$ \\
\hline TOTAL: & wt \% & $100.00 \%$ & $100.00 \%$ & $100.00 \%$ & $100.00 \%$ & $100.00 \%$ & $100.00 \%$ \\
\hline TOTAL: & $\mathrm{g}$ & 159.84 & 117.11 & 106.84 & 96.63 & 86.29 & 76.03 \\
\hline Basicity & & 0.151 & 0.232 & 0.263 & 0.305 & 0.362 & 0.445 \\
\hline
\end{tabular}

\section{ALLOY}

\begin{tabular}{|l|r|r|r|r|r|r|r|}
\hline $\mathrm{Cr}$ & wt $\%$ & $62.75 \%$ & $62.83 \%$ & $63.04 \%$ & $63.48 \%$ & $64.03 \%$ & $65.11 \%$ \\
\hline $\mathrm{Fe}$ & wt $\%$ & $24.75 \%$ & $24.25 \%$ & $24.18 \%$ & $24.20 \%$ & $24.19 \%$ & $24.36 \%$ \\
\hline $\mathrm{Si}$ & wt $\%$ & $12.51 \%$ & $12.93 \%$ & $12.78 \%$ & $12.32 \%$ & $11.78 \%$ & $10.54 \%$ \\
\hline TOTAL: & wt $\%$ & $100.00 \%$ & $100.00 \%$ & $100.00 \%$ & $100.00 \%$ & $100.00 \%$ & $100.00 \%$ \\
\hline TOTAL: & $\mathrm{g}$ & 83.83 & 87.89 & 88.16 & 87.37 & 86.71 & 83.97 \\
\hline
\end{tabular}

Page 80 
Table 31 (continued)

SOLID OXIDE

\begin{tabular}{|l|r|r|l|l|l|l|l|}
\hline $\mathrm{FeO}$ & wt $\%$ & $1.28 \%$ & & & & & \\
\hline $\mathrm{Fe}_{2} \mathrm{O}_{3}$ & wt $\%$ & $0.00 \%$ & & & & & \\
\hline $\mathrm{CaO}$ & wt $\%$ & $0.08 \%$ & & & & & \\
\hline $\mathrm{MgO}$ & wt $\%$ & $1.70 \%$ & & & & & \\
\hline $\mathrm{Al}_{2} \mathrm{O}_{3}$ & wt $\%$ & $1.35 \%$ & & & & & \\
\hline $\mathrm{Cr}_{2} \mathrm{O}_{3}$ & wt $\%$ & $0.48 \%$ & & & & & \\
\hline $\mathrm{SiO}_{2}$ & wt $\%$ & $95.11 \%$ & & & & & \\
\hline $\mathrm{TOTAL}$ & wt $\%$ & $100.00 \%$ & & & & & \\
\hline TOTAL: & $\mathrm{g}$ & 18.33 & & & & & \\
\hline PHASE: & & $\mathrm{SiO}_{2}$ & & & & & \\
\hline
\end{tabular}

The first thing to notice is the high Si content in the alloy product. The reason for this is the high $\mathrm{SiO}_{2}$ activity in the slag, which limits the amount of additional $\mathrm{SiO}_{2}$ that can be formed. Although the $\mathrm{Si}$ is substantially decreased from the $42.3 \%$ in the FeSiCr, it is still very high. However, this does not exclude this system as an option. Washing the alloy with chromite (approximately $680 \mathrm{~kg}$ of concentrate per tonne of alloy) can decrease the Si content in the alloy. The resulting slag basicity and temperature of the washed products would be approximately 0.43 and $1540^{\circ} \mathrm{C}$ respectively. At this temperature the slag should be well above its liquidus temperature. However, some of the LC FeCr alloy will start to solidify.

\subsubsection{Slag Liquidus Temperature}

The liquidus temperatures for a range of quartz additions (indicated as basicities) for the quartz slag are listed in Table 32 and shown in Figure 38. The liquidus temperatures estimated from the quaternary phase diagrams (Table 24) in the Slag Atlas are indicated. The lime and doloma slag basicities are also shown for reference on Figure 39. 
Table 32: Quartz slag liquidus temperature for different basicities.

\begin{tabular}{|c|c|c|c|}
\hline Basicity & Liquidus $\mathbf{T}\left({ }^{\circ} \mathrm{C}\right)$ & Quartz addition & Primary phase \\
\hline$(\mathrm{CaO}+\mathrm{MgO}) / \mathrm{SiO}_{2}$ & Quartz slag & t/t chromite & \\
\hline 0.460 & 1355 & 0 & $\begin{array}{l}\text { Tridymite } \\
\mathrm{SiO}_{2}\end{array}$ \\
\hline 0.362 & 1360 & 10 & $\begin{array}{c}\text { Cristobalite } \\
\mathrm{SiO}_{2}\end{array}$ \\
\hline 0.305 & 1361 & 20 & $\begin{array}{c}\text { Cristobalite } \\
\qquad \mathrm{SiO}_{2}\end{array}$ \\
\hline 0.263 & 1361 & 30 & $\begin{array}{c}\text { Cristobalite } \\
\qquad \mathrm{SiO}_{2}\end{array}$ \\
\hline 0.232 & 1361 & 40 & $\begin{array}{c}\text { Cristobalite } \\
\qquad \mathrm{SiO}_{2}\end{array}$ \\
\hline 0.151 & 1360 & 100 & $\begin{array}{c}\text { Cristobalite } \\
\qquad \mathrm{SiO}_{2}\end{array}$ \\
\hline
\end{tabular}

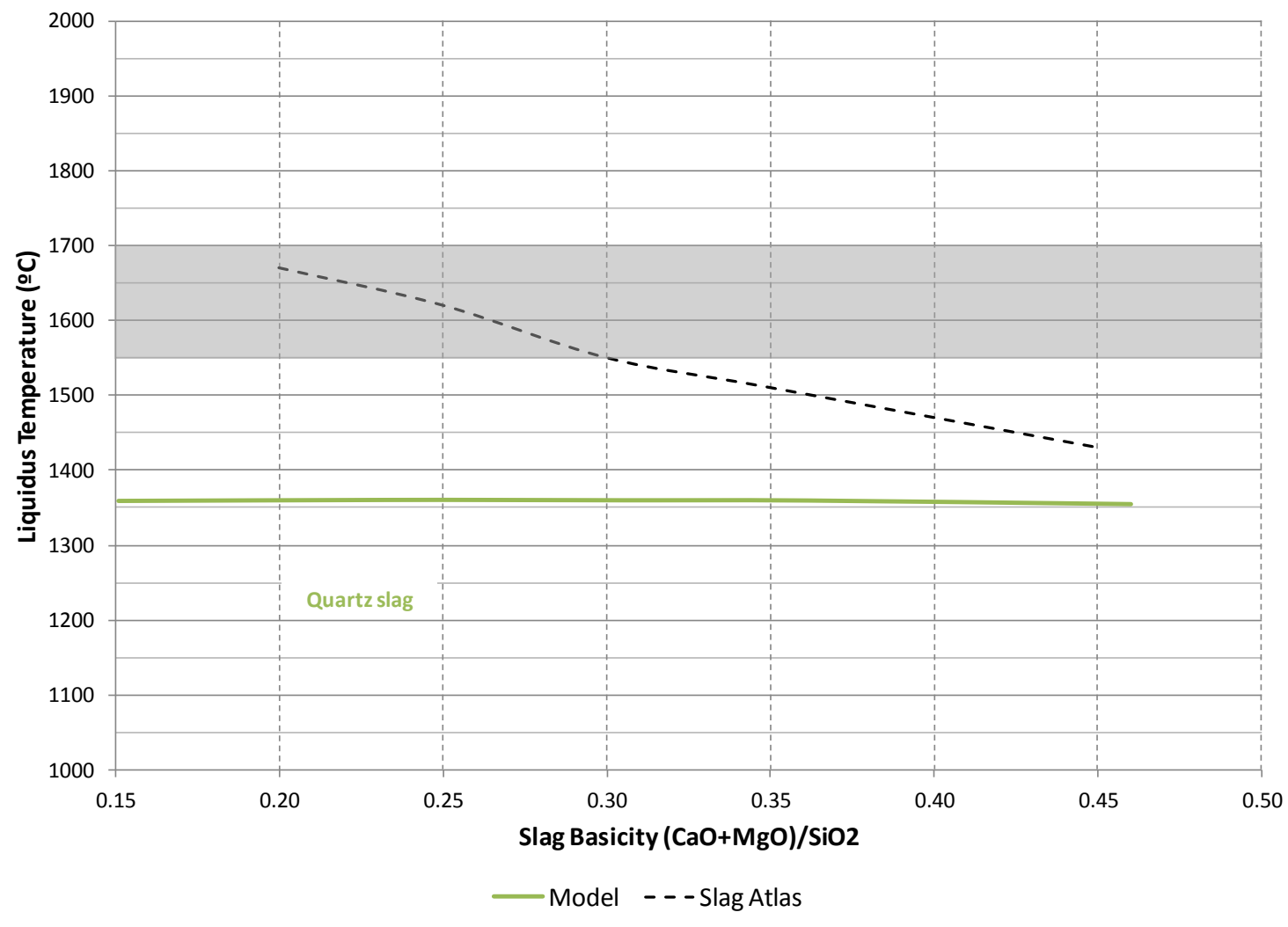

Figure 38: Liquidus temperatures for quartz slag.

Page 82

(C) University of Pretoria 


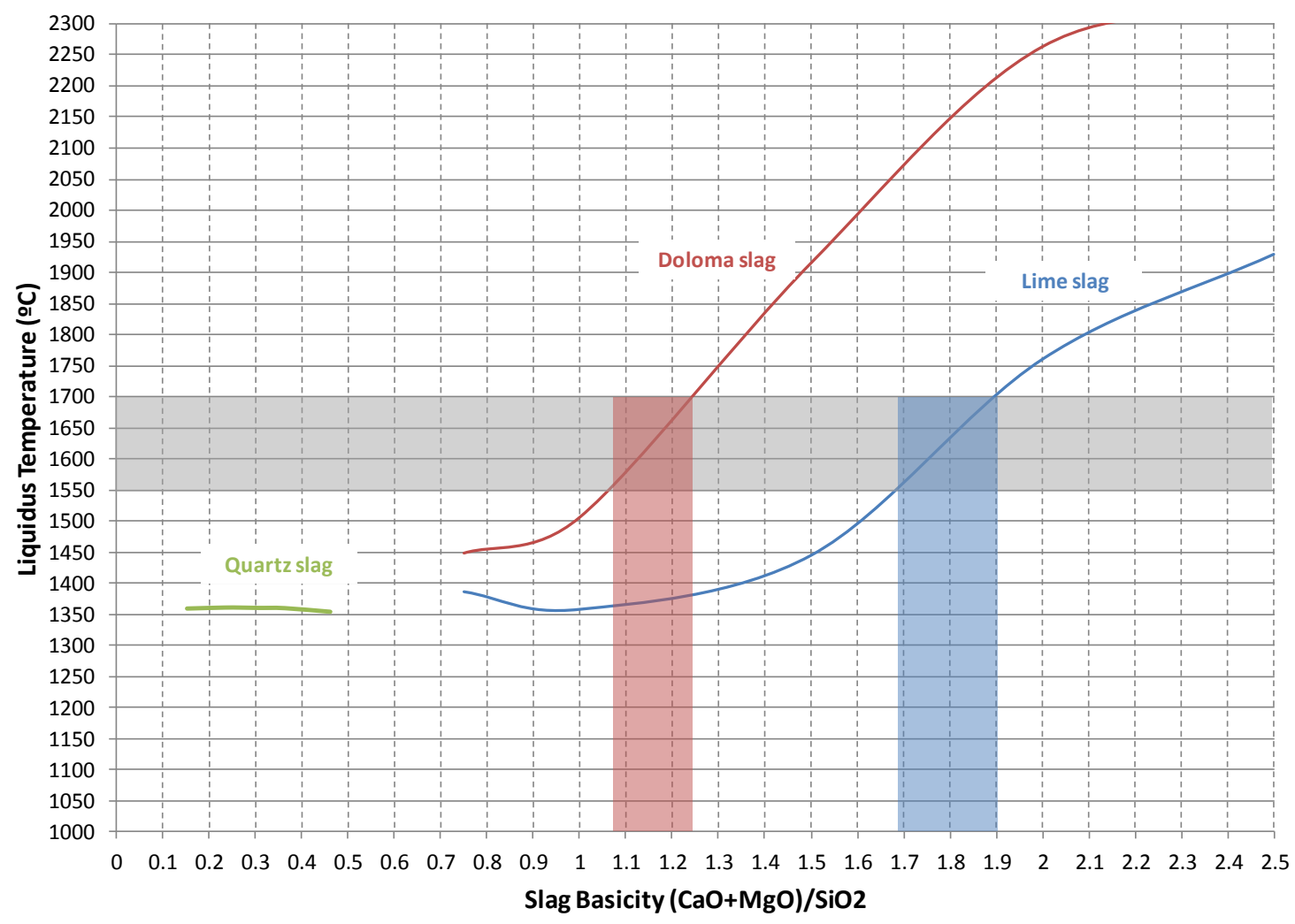

Figure 39: Liquidus temperatures for lime, doloma and quartz slag.

The data indicates that the liquidus temperature for the quartz (acidic) slag is fairly constant, but very low over the entire range evaluated. When operating at $1750^{\circ} \mathrm{C}$, the slag would therefore be highly superheated and would therefore not be suitable for the production of low carbon ferrochrome. Again, the results from the model do not compare well with those from the Slag Atlas quaternary phase diagrams.

\subsubsection{Interaction between Refractory and Slag}

Due to the low liquidus temperature of the quartz slag, the acidic system (quartz flux with alumina refractory) was considered to be unsuitable for the production of low carbon ferrochrome and modelling of the refractory-slag interaction was not performed. 


\section{LABORATORY SCALE TESTS}

Thermochemical modelling indicated that a lime fluxed slag, in contact with magnesia refractories is the most suitable setup for the production of low carbon ferrochrome. It was established that the slag becomes saturated in $\mathrm{MgO}$ above a slag basicity of 1.99. However, at this basicity, the slag liquidus temperature will be nearly $1800^{\circ} \mathrm{C}$. In order to prevent the slag from solidifying in the furnace and the ladles, a slag basicity range of 1.68 to 1.90 is required, which corresponds to the alloy liquidus temperature range of 1550 to $1700^{\circ} \mathrm{C}$.

Smelting tests were conducted at slag basicities of 1.5 and 2.0, which is slightly below and above the range identified. The reason for testing with a slag basicity of 1.5 was to determine if a passivating phase would form on the slag-refractory interface, which could potentially allow for operating at a lower slag basicity. The purpose of the 2.0 slag basicity test was to determine to what extent the higher basicity slag would inhibit reactions from occurring. Another objective of the test work was to compare the product analyses with the composition predicted by thermochemical modelling.

\subsection{Raw Material Samples}

The tests conducted at slag basicities of 1.5 and 2.0 were done using chromite concentrate and FeSiCr obtained from an existing site that uses the Mixing Method to produce LC FeCr. Due to the risk of hydration, laboratory-grade lime powder (>96\% $\mathrm{CaO}$ ) was used instead of industrial burnt lime. The analyses of the chromite and FeSiCr are given in Table 33. Models were developed to determine the raw material ratios required for the smelting tests. For this model, the chromite and FeSiCr analyses were simplified by disregarding the minority elements (which only contributed less than $1 \%$ of the raw material mass). The normalised values used in the simplified model also shown in Table 33. 
Table 33: Chromite Concentrate and Ferrochrome Silicide sample analysis.

\begin{tabular}{|l|c|c|}
\hline \multicolumn{3}{|l|}{ Chromite Concentrate } \\
\hline Component & $\begin{array}{c}\text { Mass\% } \\
\text { analysed }\end{array}$ & $\begin{array}{c}\text { Mass } \% \\
\text { model }\end{array}$ \\
\hline $\mathrm{Al}_{2} \mathrm{O}_{3}$ & 10.86 & 10.90 \\
\hline $\mathrm{CaO}$ & 0.35 & 0.35 \\
\hline $\mathrm{Cr}_{2} \mathrm{O}_{3}$ & 48.92 & 49.10 \\
\hline $\mathrm{Fe}_{2} \mathrm{O}_{3}$ & 14.06 & 14.11 \\
\hline $\mathrm{K}_{2} \mathrm{O}$ & 0.05 & \\
\hline $\mathrm{MgO}$ & 18.46 & 18.52 \\
\hline $\mathrm{MnO}$ & 0.15 & \\
\hline $\mathrm{SiO}$ & 6.99 & 7.02 \\
\hline $\mathrm{TiO}_{2}$ & 0.16 & \\
\hline $\mathrm{Total}$ & 100.00 & 100.00 \\
\hline $\mathrm{Cr}_{2} \mathrm{Fe}$ & 3.48 & \\
\hline
\end{tabular}

\begin{tabular}{|l|c|c|}
\hline \multicolumn{3}{|l|}{ Ferrochrome Silicide } \\
\hline Component & $\begin{array}{c}\text { Mass\% } \\
\text { analysed }\end{array}$ & $\begin{array}{c}\text { Mass\% } \\
\text { model }\end{array}$ \\
\hline $\mathrm{Al}$ & 1.14 & 1.15 \\
\hline $\mathrm{Ca}$ & 0.22 & \\
\hline $\mathrm{Cr}$ & 29.72 & 29.90 \\
\hline $\mathrm{Fe}$ & 17.56 & 17.66 \\
\hline $\mathrm{K}$ & 0.06 & \\
\hline $\mathrm{Mg}$ & 0.02 & \\
\hline $\mathrm{Mn}$ & 0.19 & \\
\hline $\mathrm{Si}$ & 50.98 & 51.29 \\
\hline $\mathrm{Ti}$ & 0.10 & \\
\hline $\mathrm{Total}$ & 99.99 & 100.00 \\
\hline $\mathrm{Cr} / \mathrm{Fe}$ & 1.69 & \\
\hline & & \\
\hline & & \\
\hline
\end{tabular}

The FeSiCr used for the test work had a very high silicon alloy content, as it was produced during abnormal furnace conditions during commissioning. However, this is not considered to have had a negative effect on the outcome of the test work, as the higher silicon content was offset by using a smaller amount of ferrochrome silicide.

For the 1.8 slag basicity test, a synthetic slag was made up from laboratory-grade $\mathrm{Al}_{2} \mathrm{O}_{3}, \mathrm{CaO}, \mathrm{Cr}_{2} \mathrm{O}_{3}, \mathrm{MgO}$ and $\mathrm{SiO}_{2}$ powders. The slag composition was made to correspond with that predicted by modelling for a 1.8 basicity slag.

\subsection{Equipment}

An induction furnace was used for the smelting test work. It consisted of a steel shell with an alumina lining. It contained a copper coil, in which the graphite susceptor was placed. The test materials were placed inside the susceptor. 


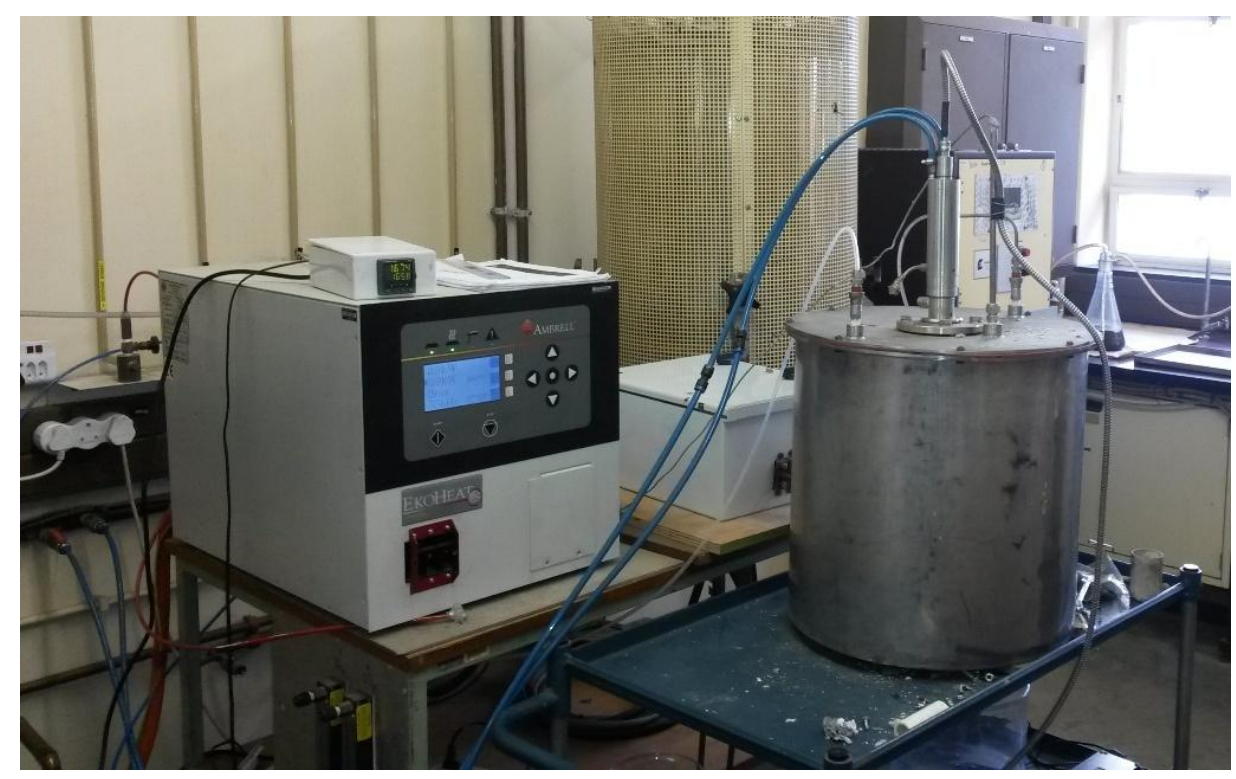

Figure 40: Experimental setup: Induction furnace with power supply.

\subsection{Testing Temperature}

Based on the low carbon ferrochrome liquidus temperature, the process temperature needs to be approximately $1750^{\circ} \mathrm{C}$. It should always be attempted to operate the process with a slag freeze lining. However, in instances where the freeze lining is lost, the slag that will be in contact with the sidewall refractory will have a temperature close to the process temperature of $1750^{\circ} \mathrm{C}$. This was therefore also the temperature used in the smelting tests. The test temperature was increased from ambient to $1750^{\circ} \mathrm{C}$ at a rate of $25^{\circ} \mathrm{C} / \mathrm{min}$ (measured with a Type $\mathrm{B}$ thermocouple placed in contact with the test crucible). Once the test temperature was reached, it was maintained for a period of 30 minutes, after which the sample was allowed to cool down.

The lid remained closed until the temperature decreased to below $200^{\circ} \mathrm{C}$ to prevent the susceptor from oxidizing, as well as to protect the seals. Although the cooling rate was set to $25^{\circ} \mathrm{C} / \mathrm{min}$, the cooling rate below $1200^{\circ} \mathrm{C}$ was much lower due to the insulation of the induction furnace. However, this was not considered to be problematic, as the 30 minute holding period was considered to have been sufficient for the reactions to reach near equilibrium conditions.

For the tests conducted for slag basicities of 1.5 and 2.0, additional energy was available from the silicothermic reduction reactions. However, the test with the synthetic slag, which had a basicity of 1.8 , only involved melting of oxides. All of the energy therefore had to be provided by the power supply. The maximum temperature that could be reached was $1500^{\circ} \mathrm{C}$. 


\subsection{Atmosphere}

The commercial-scale process would make use of a closed furnace. However, there are some openings through which air can enter the furnace. The process is a gasless one, so the atmosphere will be close to atmospheric. A small amount of argon gas was used to pressurise the test furnace slightly so as to prevent the graphite susceptor from oxidising. The actual argon flow rate was not measured. However, it was controlled so that bubbles just started to be released through the water seal at the outlet. The pressure in the furnace was therefore only slightly positive. No MgO powder was evident in the equipment after the tests.

\subsection{Crucibles}

Magnesia crucibles were used for the tests as this is the material deemed to be the most suitable for the LFFM (Section 4). The crucibles that were used in initial tests were prepared in the laboratory, using commercial-grade magnesia bricks. These refractories had a porosity of $17 \%$, which is more than the total volume of test materials used. It was believed that the pore diameter would be low enough and the slag viscosity and wetting angle high enough to prevent the slag from penetrating the refractory to a significant extent. However, after completion of the first test, little to no sample remained in the crucible.

Subsequent tests were therefore conducted using high density $(<1 \%$ open porosity) sintered magnesia crucibles. The purity of these crucibles was $>99 \% \mathrm{MgO}$, which is better than the original refractory bricks, which had an $\mathrm{MgO}$ content of $96.3 \%$. However, the original bricks contained $2 \% \mathrm{CaO}$, which amounted to a total basic oxide content of $98.3 \%$. The materials were therefore considered to be similar enough for achieving representative results. The high density crucibles had dimensions as shown in Figure 41.
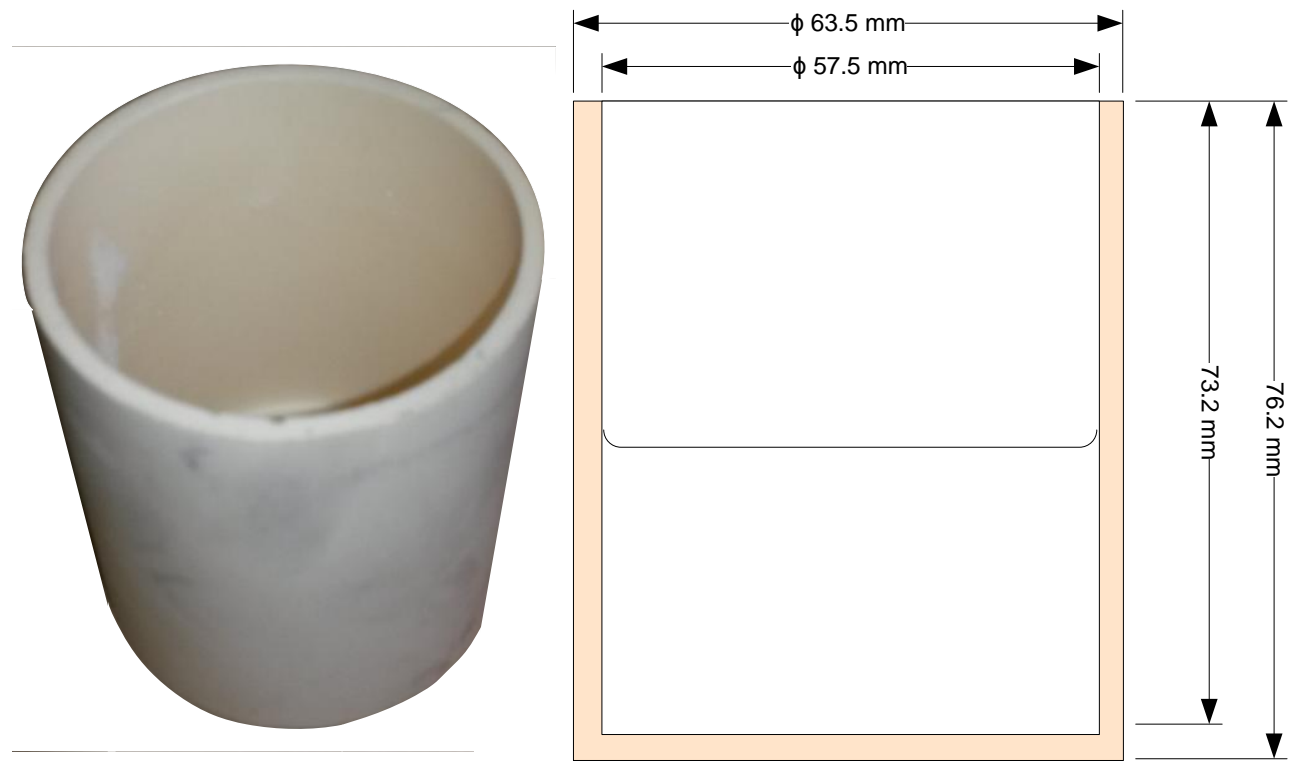

Figure 41: Photo and illustration of high density sintered magnesia crucible. 


\subsection{Sample Make-up}

The raw materials were blended to form slag samples with basicities of 1.5 and 2.0, which were slightly below and above the ideal slag basicity identified in Section 4 . The $\mathrm{FeSiCr}$ to chromite ratio was selected to produce a slag containing between 5 and $6 \%$ total chrome oxide, expressed as $\mathrm{Cr}_{2} \mathrm{O}_{3}$. The sample make-up is shown in Table 34.

Table 34: Sample make-up.

\begin{tabular}{|l|c|c|c|}
\hline Slag basicity & & 1.5 & 2.0 \\
\hline Chromite & mass \% & 57.8 & 51.7 \\
\hline Lime & mass \% & 24.5 & 32.4 \\
\hline FeSiCr & mass \% & 17.7 & 15.9 \\
\hline Total & $\mathrm{g}$ & 160.00 & 159.66 \\
\hline
\end{tabular}

\subsection{Test Procedure}

The test setup is shown in Figure 42.

The raw materials were ground in order to maximize the amount of material that could be placed in a crucible. They were properly mixed before being placed in the crucible.

Discs, cut from the original refractory, were then inserted into the raw material mixtures. The discs had a diameter of $55 \mathrm{~mm}$ and a thickness of $6 \mathrm{~mm}$. The purpose of inserting the discs was to determine if the commercial grade refractory would retain its form when in contact with the slag. As the disc had a much lower volume than the crucibles used in the initial tests, the amount of slag absorbed by the disc was not considered to be consequential.

The charged crucible was placed in the graphite susceptor and covered with a lid. The susceptor was placed inside the water-cooled copper coil and the inside of the furnace vessel was filled with alumina bubbles, up to the level of the top of the susceptor. A Type B thermocouple was inserted in a hole in the susceptor lid and rested between the crucible and susceptor. Refractory insulating wool was placed on top of the alumina bubbles and susceptor in order to limit heat loss through the roof.

The lid of the induction furnace was sealed so as to make the vessel gas tight. Cooling water was switched on and argon gas purged at a very low rate to remove air from the vessel, which would otherwise have resulted in oxidation of the graphite susceptor. The argon flow rate was kept low so as to create only a slight positive pressure. The off-gas from the furnace was bubbled through a flask which contained 
water. The outlet pipe was submerged in the water, therefore serving as a water seal to prevent air from being sucked into the furnace, especially during cooling. The flow rate was adjusted so that the gas bubbled through the water at a low rate, thereby indicating that the vessel was slightly pressurised.

Once cooled, the samples were cut in half and sectioned to provide samples that could be analysed under a Scanning Electron Microscope (SEM).

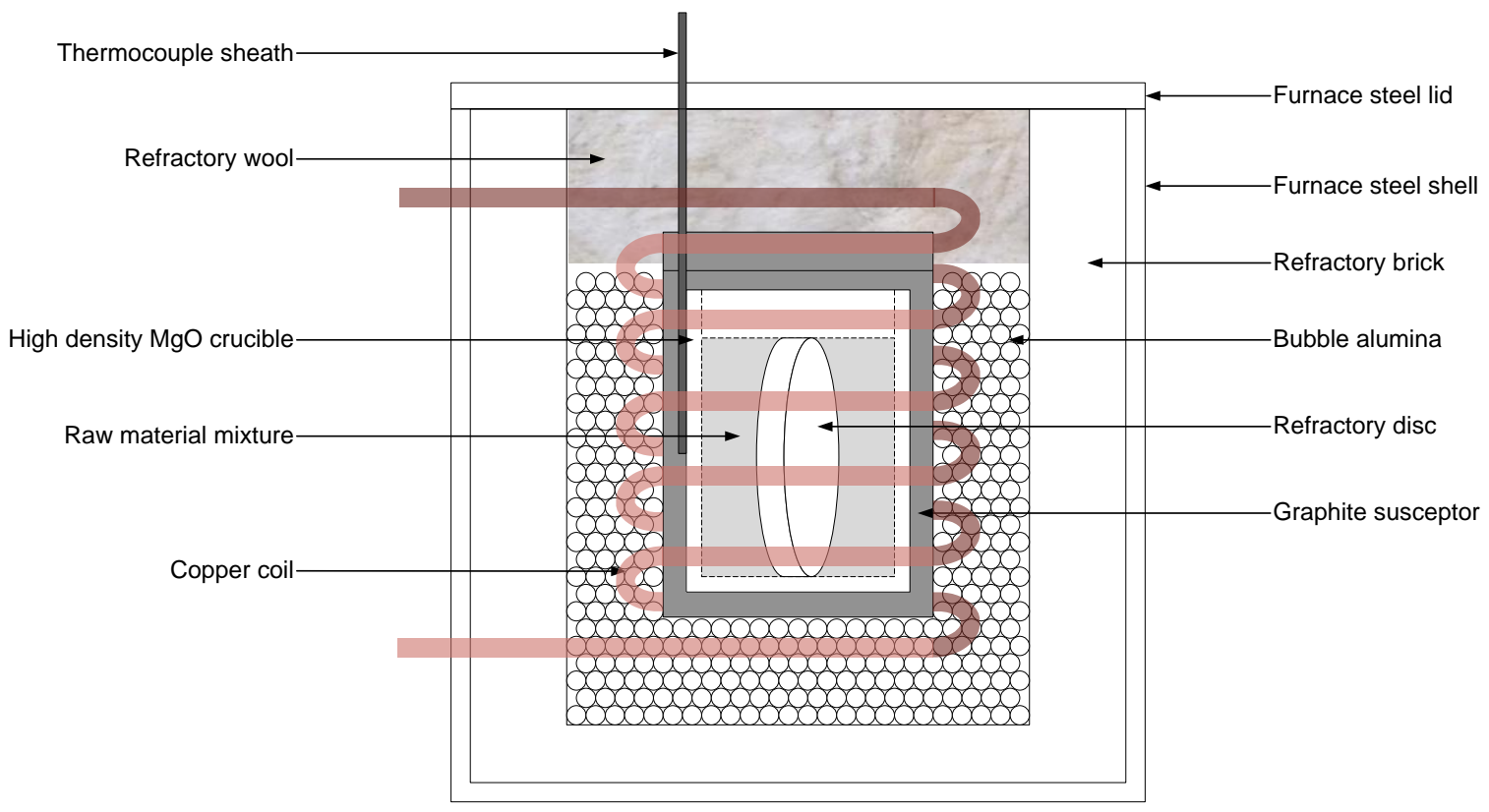

Figure 42: Illustration of experimental setup (not to scale).

\subsection{Results from Laboratory Tests}

Only average EDS analyses are reported in this section. The full sets of SEM-EDS analyses have been included in Appendix B. Note that the modelling results in this section differ slightly from those in Section 4.5.1, as the composition of the raw materials used for the laboratory test was different from those used in the thermochemical model.

\subsubsection{Slag Basicity Target $=1.5$}

A backscattered electron image of the 1.5 basicity slag is shown in Figure 43 . Three distinct phases were evident, namely the slag matrix (light grey), which made up the majority of the volume, an alloy (white) phase, which was present as spherical drops, and a dark grey metal oxide solid solution (MO) phase. The MO phase was often present as dendrites. 


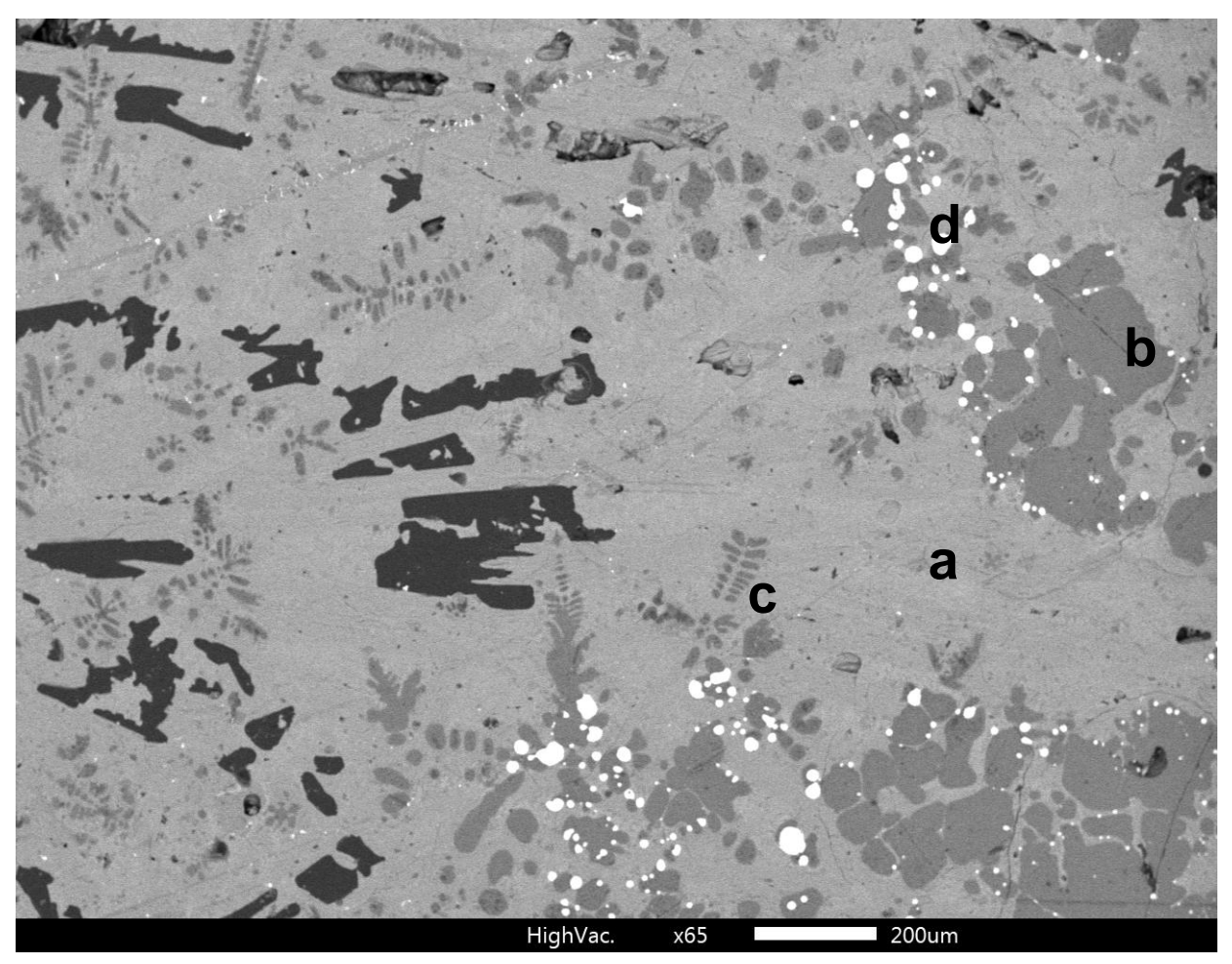

Figure 43: Backscattered Electron Image of slag phases $(B=1.5)$.

$a$ = slag matrix (light grey); $b=$ = $\mathrm{OO}$ solid solution phase (dark grey); $c=$ MO solid solution dendrite; $d=$ alloy droplets (white)

The average results of the SEM-EDS analyses of the slag matrix (bulk slag) are compared with the slag composition predicted by the model in Table 35. The results compare very well for a slag basicity target of 1.5, except for the amount of dissolved chromium oxide, which was much lower in the slag matrix of the test sample than predicted by the model. The disagreement was due to chromium oxide that formed a solid solution phase with $\mathrm{MgO}$. Only a small amount of $\mathrm{CrO}$ went in solution into the liquid slag phase. The average basicity of the slag matrix was 1.48 , which was very close to the targeted 1.5 .

The $\mathrm{MgO}$ content of the sample was slightly higher than that predicted by the model. The refractory disc that was placed in the sample was likely the source of the additional $\mathrm{MgO}$. As predicted by the model, the slag with a basicity of 1.5 would not be saturated in $\mathrm{MgO}$. The refractory disc was no longer discernible at the end of the test, which means that it was dissolved into the slag until $\mathrm{MgO}$ saturation was achieved. 
Table 35: SEM-EDS analysis of slag matrix, compared with model $(B=1.5)$.

\begin{tabular}{|c|c|c|c|}
\hline Compound & Model & $\begin{array}{c}\text { SEM-EDS, } \\
\text { average of 15 } \\
\text { analyses }\end{array}$ & $\begin{array}{c}\text { Standard } \\
\text { deviation }\end{array}$ \\
\hline wt \% $\mathrm{Al}_{2} \mathrm{O}_{3}$ & 9.69 & 9.40 & 4.03 \\
\hline wt \% $\mathrm{CaO}$ & 35.84 & 34.78 & 1.57 \\
\hline wt \% $\mathrm{Cr}_{2} \mathrm{O}_{3}$ & 0.29 & - & 0.69 \\
\hline wt \% $\mathrm{CrO}$ & 4.45 & 0.61 & \\
\hline $\begin{array}{c}\text { Total } \mathrm{CrO}_{x} \text { as } \\
\text { wt } \% \mathrm{Cr}_{2} \mathrm{O}_{3}\end{array}$ & 5.26 & 0.68 & 4.11 \\
\hline wt \% $\mathrm{MgO}_{3}$ & 15.51 & 18.94 & 1.47 \\
\hline wt \% $\mathrm{SiO}_{2}$ & 34.22 & 36.27 & \\
\hline wt \% $\mathrm{Total}$ & 100.00 & 100.00 & \\
\hline Basicity & 1.50 & 1.48 & \\
\hline
\end{tabular}

The $\mathrm{MO}$ phase often had a dendritic structure. However, the analysis was similar within $6 \%$ for the $\mathrm{Al}_{2} \mathrm{O}_{3}$ and $\mathrm{CrO}$ and within $0.2 \%$ for the $\mathrm{MgO}$. The globular and dendritic phases were therefore considered to be the same MO phase. The dendrites were formed during cooling, while the globules were present at the test temperature, which indicates that the slag was already saturated in $\mathrm{MgO}$ at $1750^{\circ} \mathrm{C}$. This was likely due to the additional $\mathrm{MgO}$ that was introduced with the refractory disc, which was placed in the raw material mix at the start of the test. The analysis of the MO phase is shown in Table 36.

Table 36: SEM-EDS analysis of MO (dark grey) phase ( $B=1.5)$.

\begin{tabular}{|c|c|c|}
\hline Compound & $\begin{array}{c}\text { SEM-EDS, average } \\
\text { of 10 analyses }\end{array}$ & $\begin{array}{c}\text { Standard } \\
\text { deviation }\end{array}$ \\
\hline wt $\% \mathrm{Al}_{2} \mathrm{O}_{3}$ & 1.23 & 0.63 \\
\hline wt \% $\mathrm{CaO}$ & 0.06 & 0.24 \\
\hline wt \% $\mathrm{CrO}$ & 3.86 & 1.05 \\
\hline wt \% $\mathrm{MgO}$ & 94.85 & 1.52 \\
\hline wt \% Total & 100.00 & \\
\hline Stoichiometry & $(\mathrm{Mg}, \mathrm{Cr}) \mathrm{O}$ & \\
\hline
\end{tabular}


The alloy produced during the test work was present as large, coalesced drops (nuggets) at the bottom of the crucible (Figure 44) and tiny droplets scattered throughout the slag, usually associated with the MO (dark grey) phase (Figure 43). The analysis of the alloy, as well as that predicted by the model, is shown in Table 37.

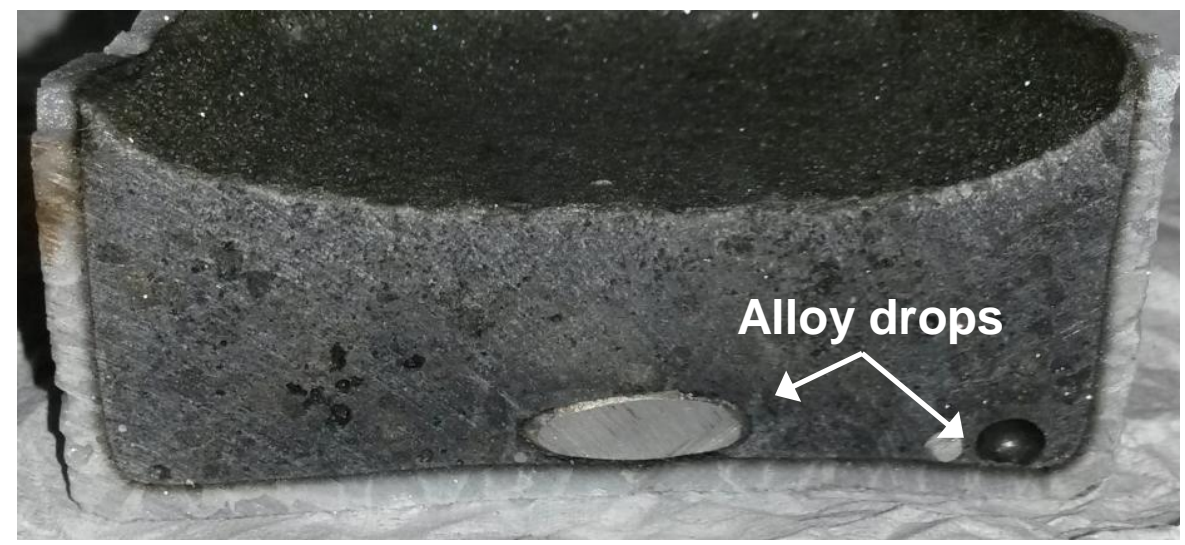

Figure 44: Sample section, indicating settling of alloy $(B=1.5)$.

Table 37: SEM-EDS analysis of alloy particles $(B=1.5)$.

\begin{tabular}{|c|c|c|c|}
\hline Compound & Model & $\begin{array}{c}\text { SEM-EDS, } \\
\text { average of } \\
7 \text { analyses }\end{array}$ & $\begin{array}{c}\text { Standard } \\
\text { deviation }\end{array}$ \\
\hline wt \% Cr & 70.80 & 73.76 & 1.82 \\
\hline wt \% Fe & 28.20 & 25.64 & 1.83 \\
\hline wt \% Mg & - & 0.18 & 0.48 \\
\hline wt \% Si & 1.00 & 0.41 & 0.11 \\
\hline wt \% Total & 100.00 & 99.99 & \\
\hline
\end{tabular}

The Cr content in the sample was slightly higher and the Si content lower than that predicted by the model. This is in agreement with the measured $\mathrm{CrO}$ analysis of the slag matrix, which was lower in the laboratory test than predicted by the model. The alloy yield could not be determined due to the small scale of the experiment. The chromium recovery could therefore not be calculated. The fact that the alloy nuggets could settle to the bottom of the crucible indicates that the slag had a low enough viscosity to allow for separation of the phases. This would be even better in a commercial sized furnace, where the alloy could be tapped at a fairly low position. 
No passivating layer formed at the slag-refractory interface. On the contrary, the slag was found to have penetrated the high density refractory (Figure 45). The slag penetrated nearly to the outside of the crucible.

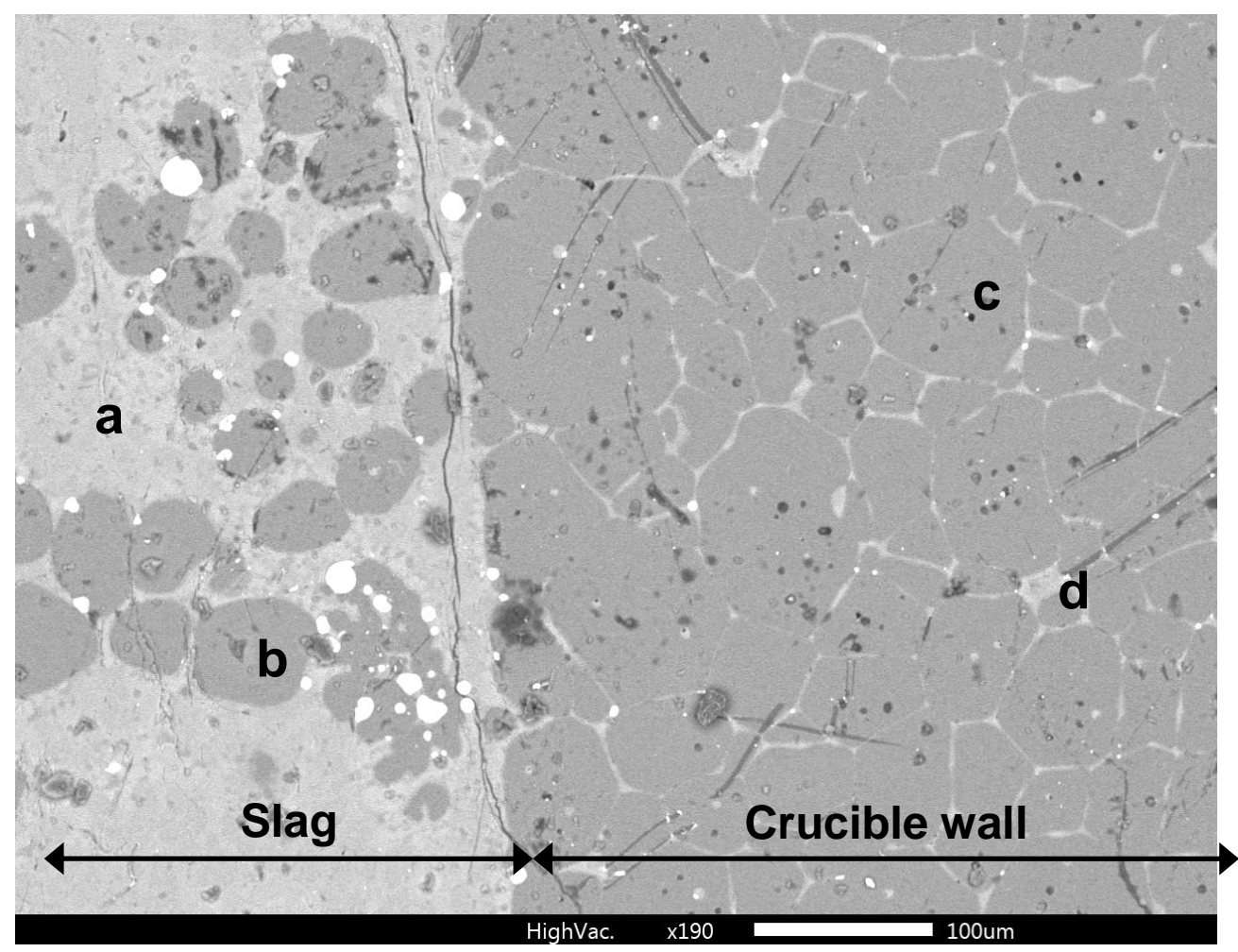

Figure 45: Backscattered Electron Image showing slag penetration in high density refractory $(B=1.5)$.

$a$ = slag matrix (light grey); $b=$ MO solid solution phase (dark grey);

$c=$ magnesia crucible $; d=$ slag penetration

The analysis of the slag that penetrated the refractory crucible is shown in Table 38. The large degree of variability in the analyses of the penetrated slag indicates that the slag that penetrated did not have a uniform composition. There was no relation between the depth of penetration of the slag and the slag composition. For all but one of the analyses, the slag had a much higher $\mathrm{MgO}$ content, which indicates that the slag had reacted with the refractory. 
Table 38: SEM-EDS analysis of slag that penetrated into magnesia crucible $(B=1.5)$.

\begin{tabular}{|c|c|c|}
\hline Compound & $\begin{array}{c}\text { SEM-EDS, average of } 6 \\
\text { analyses }\end{array}$ & Standard deviation \\
\hline wt $\% \mathrm{Al}_{2} \mathrm{O}_{3}$ & 2.17 & 2.45 \\
\hline wt \% $\mathrm{CaO}$ & 30.11 & 10.48 \\
\hline wt \% $\mathrm{CrO}$ & 1.57 & 3.11 \\
\hline wt \% $\mathrm{MgO}$ & 30.79 & 10.89 \\
\hline wt \% SiO & 9.20 \\
\hline wt $\% \mathrm{Total}$ & 32.30 & \\
\hline
\end{tabular}

Although there was some slag ingress into the refractory crucible, it was still mostly intact (Figure 46). The grains on the refractory-slag interface did show signs of wear though. While the crucible in the test did not fail catastrophically, prolonged exposure to process slag could result in a failure. Modelling showed that the slag is not saturated in $\mathrm{MgO}$ at $1750^{\circ} \mathrm{C}$ for a slag basicity of 1.5 . The presence of the $\mathrm{MO}$ globules in the slag could be due to the additional $\mathrm{MgO}$ that was introduced with the refractory disc that was placed in the raw material mixture at the start of the test. However, the solubility of $\mathrm{MgO}$ in the slag increases with a decrease in temperature down to a temperature of $1300^{\circ} \mathrm{C}$. Wear of the crucible hot face could therefore have occurred during heating. The temperature at which the crucible wear occurred needs to be confirmed before a conclusion can be drawn.

The average analysis of the crucible is shown in Table 39. 


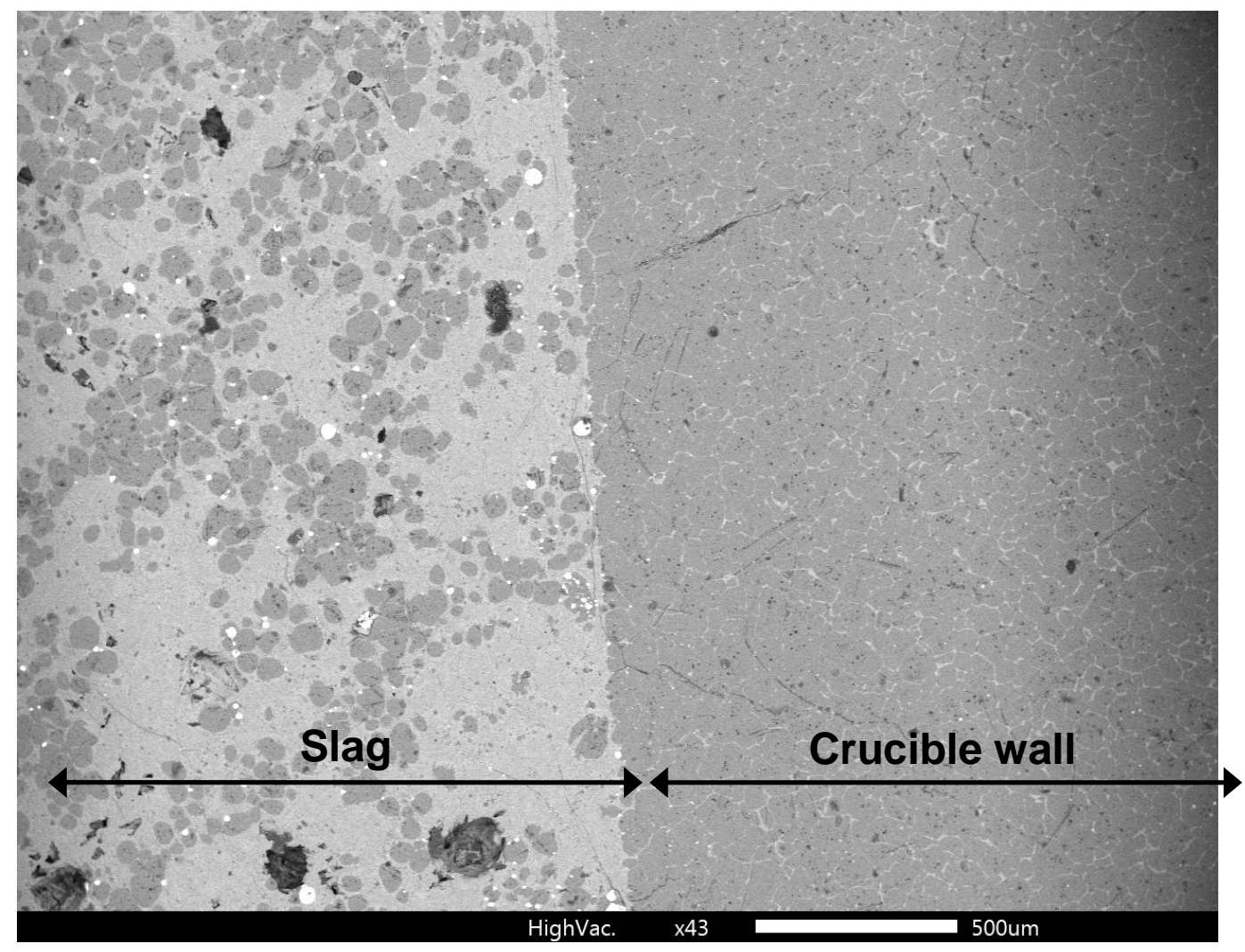

Figure 46: Backscattered Electron Image showing condition of crucible ( $B=1.5)$.

Table 39: SEM-EDS analysis of refractory crucible $(B=1.5)$.

\begin{tabular}{|c|c|c|}
\hline Compound & $\begin{array}{c}\text { SEM-EDS, average of 3 } \\
\text { analyses }\end{array}$ & Standard deviation \\
\hline wt \% $\mathrm{Al}_{2} \mathrm{O}_{3}$ & 0.87 & 0.76 \\
\hline wt \% $\mathrm{CaO}$ & 0.88 & 1.52 \\
\hline wt \% $\mathrm{CrO}$ & 2.46 & 1.93 \\
\hline wt \% $\mathrm{MgO}$ & 94.80 & 3.29 \\
\hline wt \% $\mathrm{SiO}_{2}$ & 0.99 & 1.72 \\
\hline wt \% Total & 100.00 & \\
\hline Stoichiometry & $(\mathrm{Mg}, \mathrm{Cr}, \mathrm{Ca}) \mathrm{O}$ & \\
\hline
\end{tabular}

The crucible had an $\mathrm{MgO}$ content of more than $99 \%$ at the start of the test. The results indicate that, not only did the slag enter the crucible and collect on the grain 
boundaries, but it also entered the crystal structure to form a solid solution (Mg, $\mathrm{Cr}, \mathrm{Ca}) \mathrm{O}$ phase.

The temperature at which the slag reacted with the crucible and at which the refractory disc disintegrated was not determined. More smelting tests need to be performed to determine the temperature at which the crucible is the most susceptible to slag attack.

\subsubsection{Slag Basicity Target $=\mathbf{2} .0$}

A backscattered electron image of the 2.0 basicity slag is shown in Figure 47 . The three phases identified in the 1.5 basicity slag sample were again evident (slag matrix, MO phase and alloy).

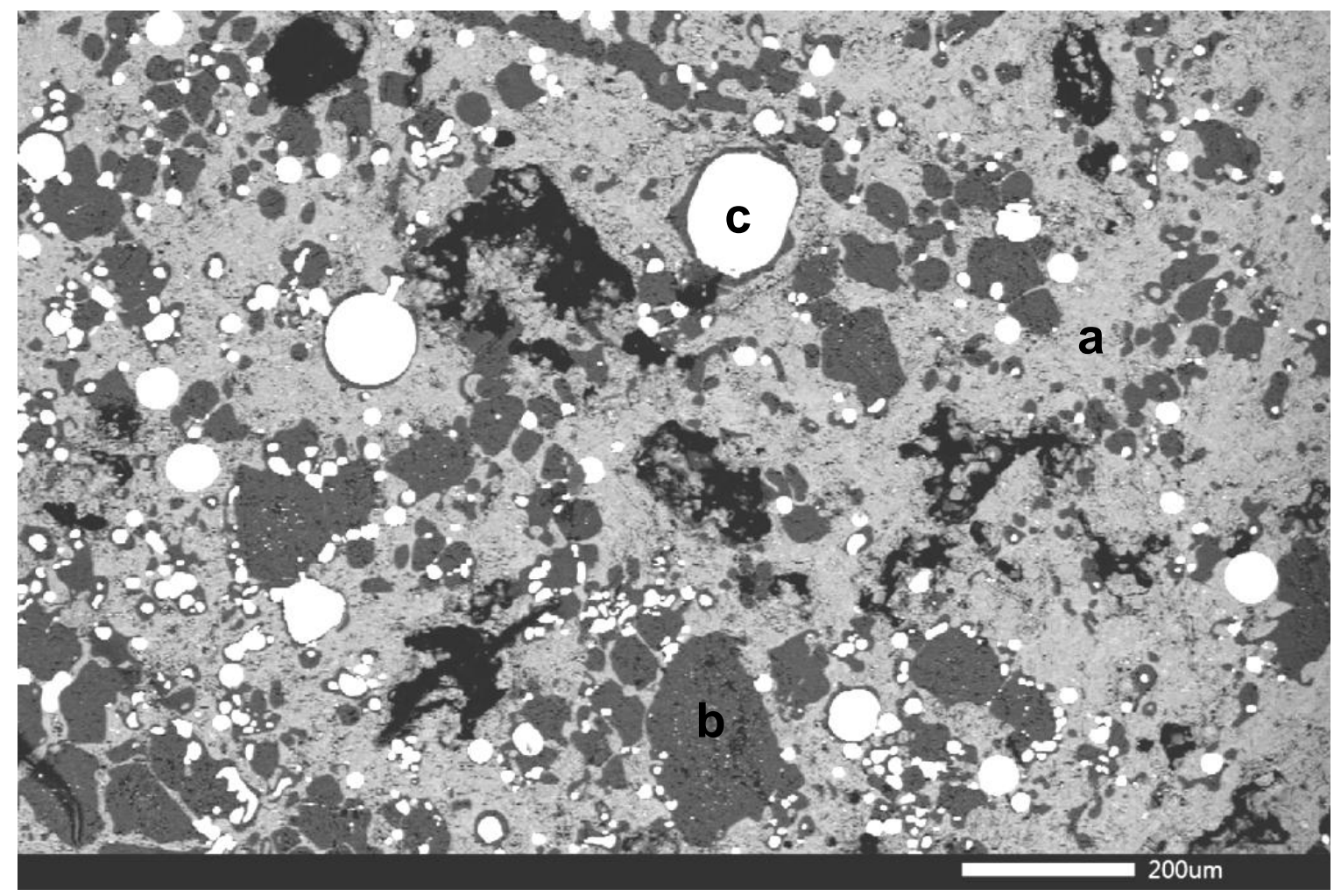

Figure 47: Backscattered Electron Image of slag phases $(B=2.0)$.

$a$ = slag matrix (light grey); $b=$ MO solid solution phase (dark grey);

$$
c=\text { alloy droplets (white) }
$$

The average results of the SEM-EDS analyses of the slag matrix are compared with the slag composition predicted by the model in Table 40. There was some disagreement between the model and the analysis from the test sample. The most significant difference was the dissolved $\mathrm{Al}_{2} \mathrm{O}_{3}$, which was much higher in the test sample. The individual analyses also varied considerably, ranging from $3.8 \%$ to 
29.1\%. The refractory disc, although severely worn, was still discernible. These would have impeded the flow of slag and alloy significantly, thereby causing the slag matrix to be heterogeneous.

Table 40: SEM-EDS analysis of slag matrix, compared with model $(B=2.0)$.

\begin{tabular}{|c|c|c|c|}
\hline Compound & Model & $\begin{array}{c}\text { SEM-EDS, } \\
\text { average of 11 } \\
\text { analyses }\end{array}$ & $\begin{array}{c}\text { Standard } \\
\text { deviation }\end{array}$ \\
\hline wt \% $\mathrm{Al}_{2} \mathrm{O}_{3}$ & 8.30 & 14.33 & 9.10 \\
\hline wt \% $\mathrm{CaO}$ & 44.44 & 42.80 & 4.13 \\
\hline wt \% $\mathrm{Cr}_{2} \mathrm{O}_{3}$ & 0.87 & - & \\
\hline wt \% $\mathrm{CrO}$ & 4.20 & - & \\
\hline $\begin{array}{c}\text { Total } \mathrm{CrO}_{\mathrm{x}} \text { as } \\
\text { wt \% } \mathrm{Cr}_{2} \mathrm{O}_{3}\end{array}$ & 5.57 & - & 1.79 \\
\hline wt \% $\mathrm{MgO}$ & 13.32 & 12.08 & 3.92 \\
\hline wt \% SiO & & 30.79 & \\
\hline wt \% $\mathrm{Total}_{2}$ & 28.87 & 100.00 & \\
\hline Basicity & 100.00 & 1.78 & \\
\hline
\end{tabular}

As was the case for a slag basicity target of 1.5 , the dissolved chromium oxide content was much lower in the slag matrix of the test sample than that predicted by the model. No chromium oxide was detected for the 2.0 basicity target. Unlike the case of the slag basicity target of 1.5, the CrO content in the MO (dark grey) phase was not as high (Table 41). However, throughout the sample the MO phase appeared to be much more prevalent than was the case for the slag basicity target of 1.5. This corresponds with the data from Table 27, which shows the MO phase to start precipitating at a slag basicity of just under 2.0 at $1750^{\circ} \mathrm{C}$. The $\mathrm{MO}$ phase contained a considerable amount of $\mathrm{CaO}$, which means that there was less $\mathrm{CaO}$ in the slag matrix. This also explains why the basicity of the slag matrix was much lower (1.78) than the target of 2.0 (Table 40).

The analyses of the MO phase were very consistent, except for one analysis, which resembled that of the slag matrix. The outlier was therefore not included in Table 41. 
Table 41: SEM-EDS analysis of MO (dark grey) phase $(B=2.0)$.

\begin{tabular}{|c|c|c|}
\hline Compound & $\begin{array}{c}\text { SEM-EDS, average of } 7 \\
\text { analyses }\end{array}$ & Standard deviation \\
\hline wt \% $\mathrm{CaO}$ & 0.42 & 0.07 \\
\hline wt \% CrO & 0.74 & 0.46 \\
\hline wt \% MgO & 98.84 & 0.44 \\
\hline wt \% Total & 100.00 & \\
\hline Stoichiometry & $(\mathrm{Mg}, \mathrm{Ca}, \mathrm{Cr}) \mathrm{O}$ & \\
\hline
\end{tabular}

The alloy produced during the test work was present as finely dispersed drops throughout the slag. Although the high occurrence of the MO phase makes it difficult to state unequivocally, it still appears that the alloy droplets tended to be associated with the MO (dark grey) phase (Figure 47). The analysis of the alloy, as well as that predicted by the model, is shown in Table 42.

The alloy content varied significantly between the analysis points, with the $\mathrm{Cr}$ content ranging between 59.5 and $95.8 \%$. The variation could again be ascribed to the presence of the refractory disc and the high amount of the MO phase, which would have inhibited the movement of the molten materials. Drawing conclusions from the average values would be highly speculative, as the precise amount of each phase could not be quantified for the sample. Unlike the sample for the 1.5 basicity test, large alloy drops (nuggets) were not evident at the bottom of the crucible or anywhere throughout the sample. Even if the average $\mathrm{Cr}$ content and the alloy yield were high, recovery of the alloy may still be low due to the large amount of solid MO phase in the slag. 
Table 42: SEM-EDS analysis of alloy particles $(B=2.0)$.

\begin{tabular}{|c|c|c|c|}
\hline Compound & Model & $\begin{array}{c}\text { SEM-EDS, average } \\
\text { of 8 analyses }\end{array}$ & Standard deviation \\
\hline wt \% Al & - & 0.02 & 0.05 \\
\hline wt \% Ca & - & 0.17 & 0.29 \\
\hline wt \% Cr & 72.75 & 75.92 & 14.49 \\
\hline wt \% Fe & 26.40 & 19.62 & 12.77 \\
\hline wt \% Mg & - & 0.48 & 0.50 \\
\hline wt \% Mn & - & 0.20 & 1.34 \\
\hline wt \% P & - & 1.01 & 1.30 \\
\hline wt \% Si & 0.85 & 2.24 & 0.35 \\
\hline wt \% Ti & - & 0.21 & 0.22 \\
\hline wt \% V & - & 0.13 & \\
\hline wt \% Total & 100.00 & 100.00 & \\
\hline
\end{tabular}

Although it was severely worn, the refractory disc could still be distinguished (Figure 48). The large number of alloy spheres on the surface of the disc could indicate that the chrome oxide was in solution with the slag and then went into solid solution with the $\mathrm{MgO}$ of the refractory disc, from where it was then reduced by $\mathrm{Si}$. 


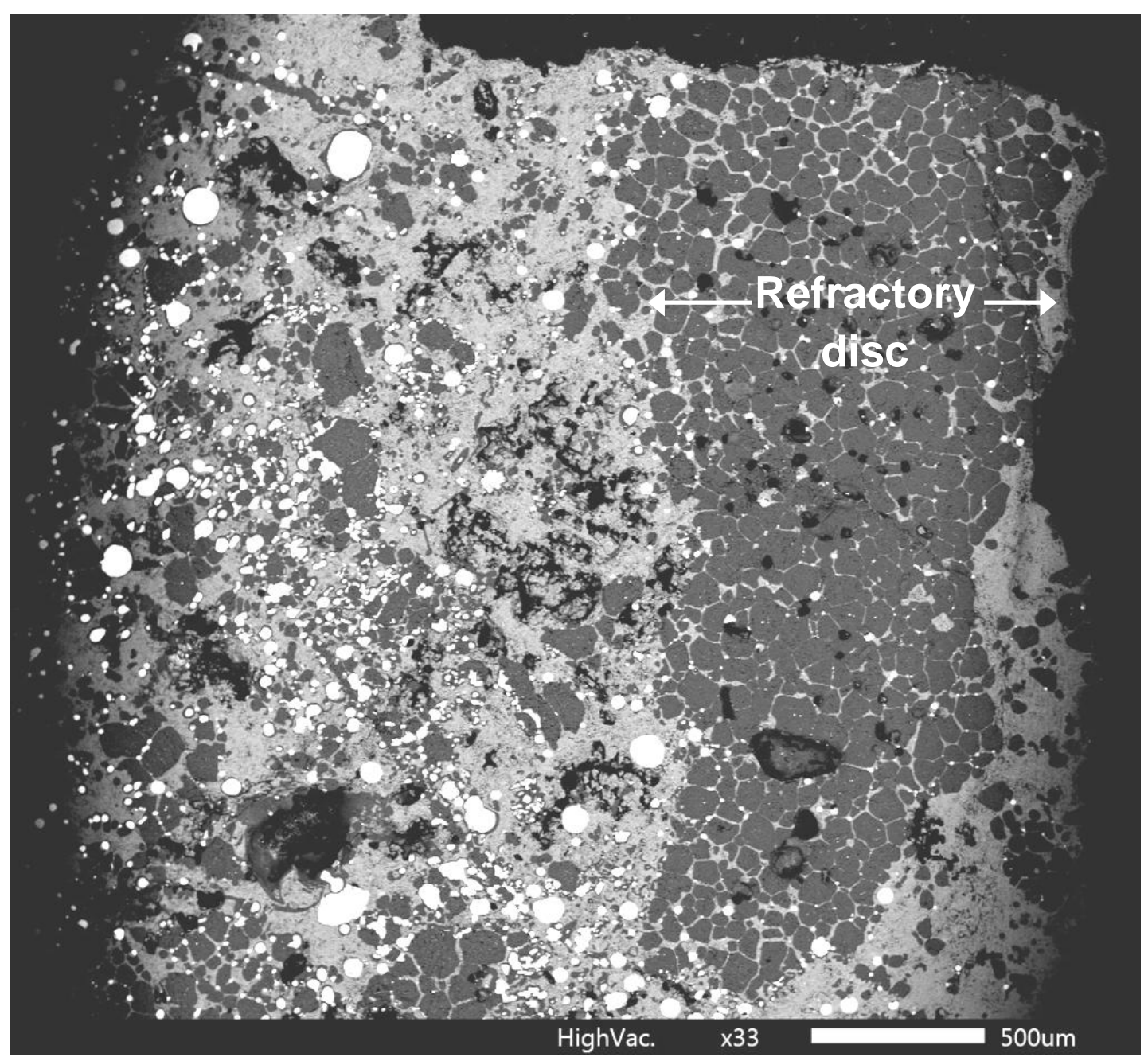

Figure 48: Backscattered Electron Image of MgO-rich structure $(B=2.0)$.

The composition of the refractory disc is shown in Table 43. The MgO content of the remaining grains of the refractory disc at the end of the test was higher than that of the original disc, which had an average $\mathrm{MgO}$ content of $96.3 \%$. Impurity phases $\left(\mathrm{CaO}-\mathrm{MgO}-\mathrm{SiO}_{2}\right)$ can typically be found along the grain boundaries of the refractory. These impurities can then be dissolved in the slag, thereby causing the refractory to disintegrate. Losing the freeze lining on a commercial furnace could therefore result in severe refractory damage, even if the slag is saturated in $\mathrm{MgO}$. 
Table 43: SEM-EDS analysis of refractory disc $(B=2.0)$.

\begin{tabular}{|c|c|c|}
\hline Compound & $\begin{array}{c}\text { SEM-EDS, average of 3 } \\
\text { analyses }\end{array}$ & Standard deviation \\
\hline wt \% $\mathrm{CaO}$ & 0.35 & 0.16 \\
\hline wt \% $\mathrm{CrO}$ & 0.39 & 0.34 \\
\hline wt \% MgO & 99.27 & 0.39 \\
\hline wt \% Total & 100.01 & \\
\hline
\end{tabular}

Figure 49 shows slag penetration similar to that seen for a slag targeted basicity of 1.5.

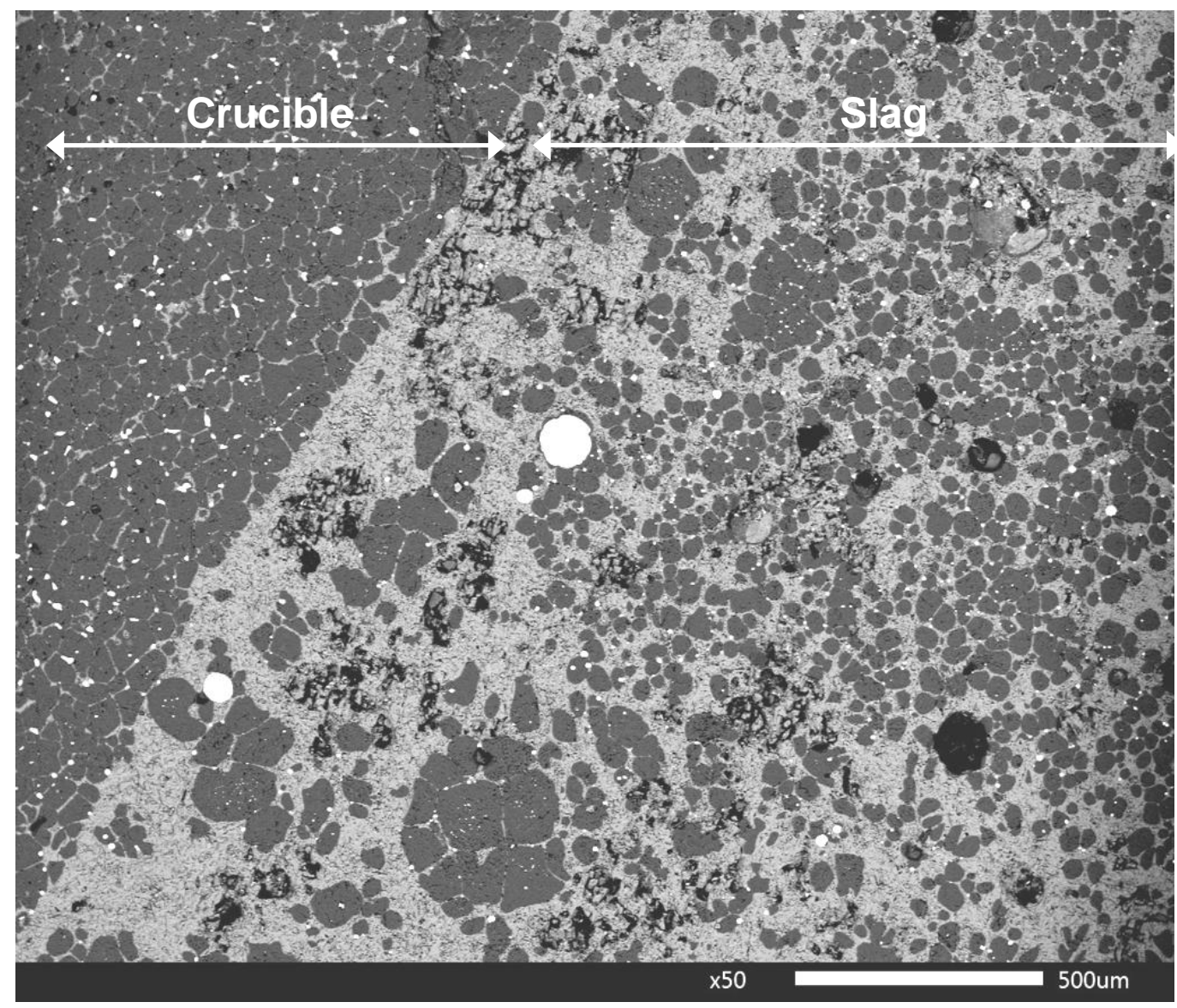

Figure 49: Backscattered Electron Image of refractory-slag interface $(B=2.0)$. 


\section{SUMMARY OF RESULTS}

\subsection{Production Methods}

For many steel grades, very low carbon concentrations are required. As the primary use of $\mathrm{LC} \mathrm{FeCr}$ is as a source of chromium in the production of steel, the carbon specification for $\mathrm{LC} \mathrm{FeCr}$ is likewise low (between 0.01 and $0.5 \%$ ). The reactions for the formation of several chromium and iron carbides are thermodynamically prevalent in carbothermic production of ferrochrome. These carbides raise the total carbon content to unacceptably high levels. Carbothermic production is therefore not used for the production of LC FeCr.

Several other processes for the production of LC FeCr have also been developed. However, none of these are economically feasible at this stage.

The only technically and economically feasible solution is production of LC FeCr by means of metallothermic reduction. Although a number of metals can be used for this purpose, only $\mathrm{Si}$ and $\mathrm{Al}$ can be used economically due to their relatively low cost. Aluminium is mostly produced on large scale, so unless the plant is located close to an aluminium production facility, silicon is the only alternative reductant that can be used for the production of $\mathrm{LC} \mathrm{FeCr}$, as it can be produced in lower quantities on site. This study therefore focussed on the silicothermic reduction of chromite, using FeSiCr as the reductant.

The allowable $\mathrm{Si}$ content in $\mathrm{LC} \mathrm{FeCr}$ is less than $1 \%$, so using silicothermic reduction for the production of $\mathrm{LC} \mathrm{FeCr}$ requires control of the $\mathrm{FeSiCr}$ to ore-lime ration.

The Mixing Method processes (Perrin and Duplex) are the most common in the production of low carbon ferrochrome. However, these processes have some shortcomings. The exothermic reactions that take place during the ladle cocktailing step, results in extremely high temperatures. This energy is lost to the atmosphere and causes unnecessary wear of the ladle refractories.

The Furnace Method makes use of the exothermic energy from the silicothermic reduction by performing the cocktailing (mixing) step in the ore-lime melt furnace. The resulting slag, which contains a large amount of $\mathrm{SiO}_{2}$, has a much lower liquidus temperature than the ore-lime mixture. The best operating regime (slag composition and basicity) and refractory system therefore had to be determined in order to evaluate the economical and technical feasibility of using the Furnace Method as an alternative to the Mixing Method.

\subsection{Techno-Economic Evaluation}

\subsubsection{Capital Cost}

The types and sizes of equipment used in both the Mixing Method and the Furnace Method processes are comparable. The capital cost is therefore not considered to be a factor when deciding between the two process routes. 


\subsubsection{Operating Cost}

High level mass and energy balances were developed for the Mixing Method (Perrin and Duplex) processes, as well as the Solid Feed and Liquid Feed Furnace Method processes (SFFM and LFFM) to determine the relative raw material and energy consumptions.

The slag composition and temperatures in the Mixing Method are dictated by the liquidus temperature of chromite. Lime is added to chromite to decrease the liquidus temperature. $\mathrm{A} 27 \% \quad \mathrm{Cr}_{2} \mathrm{O}_{3}$ ore-lime mixture is targeted, which has a liquidus temperature of just above $1830^{\circ} \mathrm{C}$. The resulting slag basicity is 2.3 .

For the Furnace Method, the slag liquidus temperature (and therefore composition) is determined by the liquidus temperature of the alloy. Low carbon ferrochrome, containing approximately $70 \% \mathrm{Cr}$, has a liquidus temperature in the region of $1700^{\circ} \mathrm{C}$, depending on the amount and type of other elements in the alloy. The operating temperature should therefore be approximately $1750^{\circ} \mathrm{C}$, which is midway between the alloy liquidus temperature and the temperature limit for magnesia refractories $\left(1800^{\circ} \mathrm{C}\right)$. This restricts the slag liquidus temperature to within a range of 1550 to $1700^{\circ} \mathrm{C}$. Quaternary phase diagrams $\left(\mathrm{Al}_{2} \mathrm{O}_{3}, \mathrm{CaO}, \mathrm{MgO}\right.$ and $\left.\mathrm{SiO}_{2}\right)$ indicated that a slag basicity range of 1.66 to 2.28 corresponded with the 1550 to $1700^{\circ} \mathrm{C}$ liquidus temperature range. A slag basicity of 1.7 was used for the cost evaluation, as a lower slag volume would amount to lower costs (less raw materials and lower power consumption).

The results from the mass and energy balances are shown in Table 44.

Table 44: Summary of mass and energy balances.

\begin{tabular}{|c|c|c|c|c|}
\hline Process & Perrin & Duplex & SFFM & LFFM \\
\hline $\begin{array}{c}\text { Chromite } \\
(\mathrm{kg} / \mathrm{t} \mathrm{LC} \mathrm{FeCr})\end{array}$ & 1497 & 1545 & 1520 & 1520 \\
\hline $\begin{array}{c}\text { Lime } \\
(\mathrm{kg} / \mathrm{t} \mathrm{LC} \mathrm{FeCr})\end{array}$ & 1216 & 1255 & 829 & 829 \\
\hline $\begin{array}{c}\text { FeSiCr } \\
(\mathrm{kg} / \mathrm{t} \mathrm{LC} \mathrm{FeCr})\end{array}$ & 632 & 637 & 635 & 635 \\
\hline $\begin{array}{c}\text { Specific Energy } \\
(\mathrm{kWh} / \mathrm{t} \mathrm{LC} \mathrm{FeCr})\end{array}$ & 2254 & 2326 & 1589 & 1202 \\
\hline
\end{tabular}


The results from the balances indicated that there is a saving of $33 \%$ in the lime consumption for the Furnace Method. The energy consumption is also 29 and $47 \%$ lower for the SFFM and LFFM respectively, compared to the Perrin process.

The labour, overheads and maintenance costs for the process routes were considered to be similar, as they are a function of the number of process units and capital cost of the equipment.

An overall saving in operating cost of 9.6 to $10.7 \%$ is achievable when using the LFFM instead of a Mixing Method process.

\subsubsection{Hexavalent Chrome}

Modelling predicted that 3.8 grams of $\mathrm{Cr}(\mathrm{VI})$ can be produced for every tonne of LC $\mathrm{FeCr}$ in the Mixing Method ore-lime melt furnace (at $1900^{\circ} \mathrm{C}$ ). Leaching tests done on a dust sample from a Perrin process indicated that an average of $23 \mathrm{~g}$ of $\mathrm{Cr}(\mathrm{VI})$ is produced for every tonne of $\mathrm{LC} \mathrm{FeCr}$. The $\mathrm{Cr}(\mathrm{VI})$ for each tonne of $\mathrm{LC} \mathrm{FeCr}$ therefore has the potential to pollute more than 46 kilolitres of groundwater, by raising its $\mathrm{Cr}(\mathrm{VI})$ content above the allowable limit. The difference between the values predicted by the model and leaching tests can be ascribed to the fact that $\mathrm{Cr}(\mathrm{VI})$ in the model originates solely from fumed chromium, while in fact a large fraction of the $\mathrm{Cr}(\mathrm{VI})$ may originate from raw material carryover and slag splashing.

A model of the Furnace Method predicted no $\mathrm{Cr}(\mathrm{VI})$ to have formed (by fuming of chromium). Some $\mathrm{Cr}(\mathrm{VI})$ may still form from raw materials being carried over with the off-gas and slag particles. However, this is expected to be much lower than that of the Mixing Method as the furnace is closed and the air ingress is therefore minimal. Unfortunately no dust samples from the Furnace Method were available at the time of writing.

\subsection{Thermochemical Modelling}

The required slag liquidus temperature range, which is dictated by the liquidus temperature of the alloy, is 1550 to $1700^{\circ} \mathrm{C}$. Modelling was done where varying amounts of lime or doloma were added to produce a slag with a liquidus temperature within this range. Magnesia and doloma refractories were also modelled, in contact with the different slag systems, to determine which would be the most compatible combination. For the sake of thoroughness, a quartz fluxed slag, in contact with an alumina lining was also modelled to determine if there could be any unexpected benefits. However, the study focussed on the basic systems as these are known to promote chromium reduction.

\section{Model range identification}

Quaternary phase diagrams $\left(\mathrm{Al}_{2} \mathrm{O}_{3}, \mathrm{CaO}, \mathrm{MgO}\right.$ and $\left.\mathrm{SiO}_{2}\right)$ were used to identify the range of slag basicities that would most likely yield a slag with a liquidus temperature within the 1550 to $1700^{\circ} \mathrm{C}$ range. Detailed thermochemical models were then developed, using FactSage 6.4, using these target basicity ranges. The basicity targets used in the models were $0.75,1.0,1.5,2.0$ and 2.5 . 


\section{Operating methodology modelling}

Models were developed for two operating methodologies, namely adding liquid FeSiCr to an ore-lime melt, and adding an ore-lime mixture to liquid FeSiCr. The two operating methodologies were evaluated to determine how the slag and alloy compositions would vary throughout the heats. This would assist in deciding at which point during the heat to add the different raw materials.

For the first case (adding liquid FeSiCr to an ore-lime melt), the slag basicity started off at a high value and gradually decreased as FeSiCr was added. This was expected, as there was little $\mathrm{SiO}_{2}$ in the ore and the lime used in the model. The slag produced was considered to be compatible with the refractory for the entire heat. However, the high basicity ore-lime mixture may have such a high liquidus temperature during the initial stages that it is difficult to melt and therefore prevents proper mixing with the $\mathrm{FeSiCr}$.

For the second case (adding an ore-lime mixture to liquid FeSiCr), one would have expected the basicity to remain constant throughout the heat, as all of the ore-lime mixture that was added had sufficient FeSiCr to react with. However, this was not the case, as the slag basicity was found to be much lower at the start of the heat and gradually increased to the target basicity towards the end of the heat. The Mg lost to the gas phase also increased with an increase in the ore-lime mixture until approximately half of the ore-lime mixture was added. After this it decreased again to virtually zero. This is caused by a high $a_{S i}$ in the FeSiCr and a low $a_{S i O 2}$ in the slag, which drives the reduction of $\mathrm{Mg}$.

While the first methodology (adding $\mathrm{FeSiCr}$ to an ore-lime melt) has some risk of improper mixing, as well as not utilising the energy from the exothermic reactions to melt the ore-lime mixture, the second methodology (adding ore-lime mixture to liquid $\mathrm{FeSiCr}$ ) poses a severe risk to the integrity of the refractory lining. The answer would therefore be to use a combination of these extremes. In practice, this means calculating the amount of ore-lime mixture that can be melted by the energy from the exothermic reactions. This fraction would be fed after adding the liquid $\mathrm{FeSiCr}$, while the remainder would be fed at the start of the heat (before adding FeSiCr).

For the SFFM, control of the energy and chemistry balance would be much easier, although the specific energy requirement for the process would be slightly higher.

\subsubsection{Magnesia Refractory, Lime Slag}

The model inputs were selected to produce a slag product that contained between 5 and $6 \%$ chrome oxides, presented as $\mathrm{Cr}_{2} \mathrm{O}_{3}$. This is slightly higher than the 2 to $3 \%$ quoted for the Mixing Method processes. However, the reaction kinetics are expected to be slower for the Furnace Method as the turbulence in the furnace would be less than during the cocktailing step in the Mixing Method. Although the final slag $\mathrm{Cr}_{2} \mathrm{O}_{3}$ content could be decreased to within the required 2 to $3 \%$ by introducing a slag washing step after tapping from the furnace, modelling was done to describe the reactions in the furnace only. 
For the lime fluxed slag, the Cr content in the alloy increased and the Si content decreased with an increase in the slag basicity. This is in agreement with literature. This $\mathrm{Si}$ content is below the required $1 \%$ at a slag basicity above 1.5 . Between a slag basicity of 2.0 and 2.5, an MgO-rich solid phase starts to form, indicating that the slag is saturated in $\mathrm{MgO}$ and that the liquidus temperature is above $1750^{\circ} \mathrm{C}$, which is the temperature used in the models. No $\mathrm{Cr}(\mathrm{VI})$ was predicted to have formed and the $\mathrm{Mg}$ content in the alloy was found to be nearly zero.

The slag liquidus temperature was plotted as a function of the slag basicity. The slag basicity range that corresponded to a slag liquidus temperature of 1550 to $1700^{\circ} \mathrm{C}$ was 1.68 to 1.90 . This is lower than the range of 1.87 to 2.27 predicted from the quaternary phase diagrams. The difference between the model and the quaternary system could be ascribed to the presence of $\mathrm{CrO}$ in the slag, which was included in the model, but not the quaternary phase diagrams.

The primary solidification phase for a basicity below 1.5 is forsterite. At a basicity of 1.5 spinel is the primary phase, while above 1.5 periclase becomes the primary solidification phase.

Modelling the refractory-slag interface is not practical, as it is essentially a layer with a thickness of one molecule. The reaction kinetics would therefore be crucial in determining the extent to which the materials would react. Instead, the models were used to determine the solubility of $\mathrm{MgO}$ in the slag for the basicity range.

Slag was incrementally introduced to a fixed mass of magnesia refractory. For the refractory to be compatible with the slag, the total liquid slag mass of the system should have increased with the same amount or less than that of the slag which was introduced (the stability limit). If the equilibrium slag mass was found to be higher than the slag introduced, it would indicate that some of the refractory was dissolved in the slag. The stability limit was determined to be at a slag basicity of 1.82 .

What this approach did not consider was that phases other than high-MgO phases could precipitate from the slag, while $\mathrm{MgO}$ is dissolved in the slag. The net effect could then be that the slag mass is less than that which was introduced, but that the refractory was still being damaged. The total solid $\mathrm{MgO}$ was therefore also plotted as a function of the slag basicity and was found to be stable at a slag basicity above 1.99 .

In practice, operating between 1.82 and 1.99 should not be problematic, as particles that precipitate from the slag would likely accumulate around the furnace periphery, where the temperature is lower than the process temperature, assuming that the slag bath is not excessively turbulent.

\subsubsection{Doloma Refractory}

A similar approach was followed for the refractory-slag interaction as was used for the magnesia refractory, lime slag system. The models indicated that, for the entire slag basicity range, more slag would be present than that which was introduced. Even when no slag was added (only the refractory was present), $14 \%$ of the 
refractory was molten. The process temperature was therefore above the solidus temperature of the refractories at a temperature of $1750^{\circ} \mathrm{C}$. Doloma refractories would therefore not be suitable for the production of low carbon ferrochrome, irrespective of the slag system used.

\subsubsection{Magnesia Refractory, Doloma Slag}

Periclase starts to precipitate from the slag above a basicity of 1.41 . This also coincides with a decrease in the alloy $\mathrm{Cr}$ content, which reaches a maximum at a slag basicity of approximately 1.5. The alloy $\mathrm{Si}$ content decreases over the entire slag basicity range, falling below the required $1 \%$ at a slag basicity of 1.5 .

The doloma slag has a liquidus temperature that is much higher than that of the lime slag for the entire basicity range. The doloma slag is also more saturated in $\mathrm{MgO}$, resulting in lower magnesia refractory dissolution at lower basicities. Each of these characteristics would make this system preferable to that of the magnesia refractory, lime slag system. However, combined they do not. The slag becomes saturated in $\mathrm{MgO}$ above a basicity of 1.4. At this point, the slag liquidus temperature is already above $1810^{\circ} \mathrm{C}$, which is above the specified limit for magnesia refractories.

\subsubsection{Alumina Refractory, Quartz Slag}

The $\mathrm{Cr}$ content in the alloy increases and the Si content decreases with an increase in slag basicity. However, the alloy Si content remains high (above 10\%) due to the high $\mathrm{a}_{\mathrm{SiO} 2}$ in the slag, which limits silicothermic reduction. Additional slag washing is therefore required to improve the chromium recovery. This is not too critical, as washing may be needed for other slag systems as well.

However, using quartz as a flux results in a slag with a very low liquidus temperature. As the process temperature is limited by the liquidus temperature of the alloy, high quartz slag would not be suitable for the production of low carbon ferrochrome.

\subsection{Laboratory Tests}

Smelting tests were performed, using chromite concentrate, FeSiCr and burnt lime to form slag products with target basicities of 1.5 and 2.0. Thermochemical modelling indicated that the ideal range should be between 1.5 and 2.0 (Section 4). These tests therefore indicated the effects of operating at both extremes of the identified range.

\subsubsection{Slag Basicity Target $=\mathbf{1} .5$}

The composition of the slag matrix was very similar to that predicted by the thermochemical model, except that there was very little dissolved chromium oxide in the slag, while the model predicted the chrome oxide content to be between 5 and $6 \%$. This difference was due to $\mathrm{CrO}$ forming a solid solution phase with $\mathrm{MgO}$. The average slag basicity of the slag matrix was 1.48 , which was very close to the targeted basicity of 1.5 . 
Some of the slag penetrated into the refractory crucible. The composition of this slag varied significantly between sampling points, but had consistently high $\mathrm{MgO}$ contents, which indicates that it reacted with the refractory crucible. As the bulk slag was not saturated in $\mathrm{MgO}$, the slag could react with the test crucible. Movement of the slag that penetrated the crucible would have been restricted, thereby allowing it to absorb $\mathrm{MgO}$ from the crucible up to the point where it becomes saturated in $\mathrm{MgO}$.

The MgO content of the slag matrix was slightly higher than that predicted by the model. The magnesia refractory disc, which was inserted into the feed mixture prior to the test, was completely dissolved in the slag. This is thought to have been the source of the additional $\mathrm{MgO}$ in the slag matrix.

The alloy was present as large, coalesced drops (nuggets) at the bottom of the crucible, as well as droplets that were mostly associated with the MO phase that was observed throughout the sample. The large nuggets at the bottom indicate that the slag viscosity was low enough to allow for separation of the alloy from the slag. The reaction mechanism needs to be evaluated in more detail in order to determine the reason for the association of the alloy and MO phase.

The alloy from the test sample had a higher $\mathrm{Cr}$ content and lower Si content than that predicted by the model. This agrees with the lower $\mathrm{CrO}_{x}$ content of the slag matrix. The reason for the increase in chromium reduction needs to be investigated further. The alloy yield was not determined and the chromium recovery could therefore not be calculated.

No passivating layer formed on the slag-refractory interface. Although the crucible was still in tact, slag had penetrated to the outside of the crucible. This slag was very similar to the slag matrix, except that it had a higher $\mathrm{MgO}$ content, which indicates that it had reacted with the crucible.

The slag penetration into the crucible, along with the refractory disc dissolving into the slag, confirm the modelling results which predicted that the slag would not be saturated in $\mathrm{MgO}$ at a slag basicity of 1.5 . However, the wear on the crucible and refractory disc may have been at a lower temperature, as the sample was heating up or cooling down. Further testing is required to determine the temperature range at which the refractory material is most susceptible to slag attack. Whatever the high risk temperature range is, it is clear that a slag freeze lining is required to protect the refractory from reacting with the slag. If the majority of the refractory wear occurred at lower temperatures, cycling of the process (frequent stopping and starting) should be avoided as far as possible in order to minimise the duration operating within the high risk temperature range.

\subsubsection{Slag Basicity Target $=2.0$}

There was a large degree of variability in the analysis of the slag matrix throughout the sample. The high amount of the MO phase would have inhibited the movement of slag and metal, thereby resulting in a product which was not homogenous. 
The slag matrix had an average basicity of 1.78 , which was lower than the targeted basicity of 2.0. Periclase was identified as the primary solidification phase (Table 28). Upon cooling, the precipitation of periclase, along with a significant amount of $\mathrm{CaO}$, would have decreased the amount of basic slag components ( $\mathrm{MgO}$ and $\mathrm{CaO}$ ) of the slag matrix, thereby decreasing the basicity of the slag matrix. Decreasing the temperature of the thermochemical model resulted in a similar decrease in the slag basicity.

The alloy had a higher $\mathrm{Cr}$ content than predicted by the model, but the analyses were just as variable as that of the slag. All of the alloy was present as fine drops, associated with the MO phase. Recovery of the alloy may therefore be difficult at this basicity.

The refractory disc that was placed in the mixture prior to the test was severely worn. At lower temperatures a greater amount of the MO solid solution phase is present, resulting in a lower basicity slag matrix, which could react with the refractory. A slag freeze lining would therefore still be required, even when operating at a slag basicity of 2.0 . 


\section{CONCLUSIONS}

\subsection{Production Routes}

Due to the strict limit on the allowable carbon content, carbothermic reduction can not be used for the production of LC FeCr. Although there are several alternative processes for the production of LC FeCr, metallothermic reduction of chromite ore, using silicon or aluminium as reductant, is preferred due to its relatively low cost and low losses, compared to alternative processes. Unless an aluminium production facility is located close to the LC FeCr plant or if there is easy access to recycled aluminium, only silicon can be used as the reductant, as it can be produced on site at the rates required for $\mathrm{LC} \mathrm{FeCr}$ production.

\subsection{Techno-Economic Evaluation}

A qualitative review of the plant capital cost indicates that there should be little difference between the cost for the Mixing Method and Furnace Method processes.

A model of the operating costs indicated that there is a saving of $33 \%$ in the lime consumption for the Furnace Method when compared to the Mixing Method. The energy consumption is also 29 and 47\% lower for the SFFM and LFFM respectively, compared to the Perrin process. Other operating costs, such as labour, overheads and maintenance costs were considered to be similar, as they are a function of the number of process units and capital cost of the equipment. An overall saving in operating cost of 9.6 to $10.7 \%$ is achievable when using the LFFM instead of a Mixing Method process.

The higher temperature and basicity, as well as the presence of abundant oxygen (air) makes the Mixing Method more conducive to the formation of $\mathrm{Cr}(\mathrm{VI})$ than the Furnace Method. Thermochemical modelling confirms this, as no $\mathrm{Cr}(\mathrm{VI})$ was predicted to form when using the Furnace Method, but 3.8 grams of $\mathrm{Cr}(\mathrm{VI})$ was expected to form for every tonne of LC FeCr produced using the Mixing Method. Leaching tests done on a dust sample from an existing Mixing Method process indicated that the $\mathrm{Cr}(\mathrm{VI})$ content can be much higher than that predicted by modelling. This is likely due to chromite, slag and alloy carry-over to the off-gas, which was not included in the thermochemical models.

\subsection{Thermochemical Modelling}

The required slag liquidus temperature range, which is dictated by the liquidus temperature of the alloy, is 1550 to $1700^{\circ} \mathrm{C}$. Modelling was done on a range of slag compositions, using lime, doloma or quartz as a fluxing material. Of these systems, only lime and doloma fluxed slag systems had liquidus temperatures within the 1550 to $1700^{\circ} \mathrm{C}$ range.

Further models were developed to determine whether or not any of these slags would be compatible with either a magnesia or a doloma lining. Of all the combinations of slag and refractory systems modelled, only a lime slag in contact 
with a magnesia lining was found to be compatible. The slag was found to be completely saturated in $\mathrm{MgO}$ above a slag basicity of 1.99 . However, at a slag basicity above 1.82 , other oxides already start to precipitate from the slag, which should make operation at this basicity possible, especially if the furnace shell is water-cooled to assist in forming a freeze lining.

Feeding all of the ore-lime mixture to the furnace before feeding the FeSiCr will result in the formation of a high liquidus slag at the start of the heat. It also negates the benefit of using the exothermic energy from the silicothermic reduction process, as the ore-lime mixture needs to be melted by electrical energy before the FeSiCr can be added. On the other hand, feeding all of the FeSiCr at the start of the heat, before introducing the ore-lime mixture, will result in damage to the refractory material, as the $\mathrm{Si}$ in the FeSiCr will reduce $\mathrm{Mg}$ in the refractory. Feeding a portion of the ore-lime mixture, followed by the FeSiCr before feeding the last of the ore-lime mixture, will ensure that the exothermic energy of the silicothermic reduction is utilised, while maintaining a liquid slag bath and protection for the refractory sidewall.

\subsection{Laboratory Tests}

Smelting tests were performed, using chromite concentrate, $\mathrm{FeSiCr}$ and burnt lime to form slag products with target basicities of 1.5 and 2.0, which encompasses the ideal basicity range identified by thermochemical modelling.

\subsubsection{Slag Basicity Target $=1.5$}

The composition of the slag matrix was very similar to that predicted by the thermochemical model, except that there was very little chrome oxide in the slag, while the model predicted the chrome oxide content to be between 5 and $6 \%$. The $\mathrm{MgO}$ content was slightly higher than the model predicted. However, a refractory disc, which was placed in the mixture at the start of the test, was completely dissolved. This would have increased the $\mathrm{MgO}$ content of the slag.

Some of the slag penetrated the refractory crucible. This slag composition was not uniform, but had consistently high MgO contents. The slag therefore absorbed some of the $\mathrm{MgO}$ from the crucible. This indicates that slag with a basicity of 1.5 is not compatible with a magnesia lining, which is in agreement with the model. It is therefore critical to operate a commercial furnace with a freeze lining, as failing to do so would result in rapid wear of the refractory lining. If the majority of the refractory wear occurred at lower temperatures, it is crucial that cycling of the process be avoided so that time in the high risk temperature range be minimised.

The alloy $\mathrm{Cr}$ content was higher than predicted by modelling which, along with the lower $\mathrm{CrO}_{x}$ content of the bulk slag, is indicative of a higher degree of reduction than that predicted by thermochemical modelling. The reaction mechanisms need to be evaluated in more detail in order to determine the reason for this. The alloy appears to be able to settle out of the slag, which would ensure good recovery of the alloy. However, the amount of alloy associated with the solid MO phase, as a fraction of the 
total alloy produced, was not determined. A larger scale test may assist in quantifying this split and evaluating the recoverability of the alloy.

\subsubsection{Slag Basicity Target $=\mathbf{2} .0$}

The slag and alloy analyses varied throughout the sample. The liquidus temperature of a slag with a basicity of 2.0 was calculated to be $1760^{\circ} \mathrm{C}$ ( Table 28), with periclase as the primary solidification phase. Solid material in the slag would inhibit movement of the liquid and result in a product that is very heterogeneous.

The refractory disc that was placed in the mixture at the start of the test was still discernible at the end of the test. The MgO content of the refractory disc was higher towards the end, supporting the modelling results which showed the slag to be nearly saturated in $\mathrm{MgO}$ at a slag basicity of 2.0. Although the other elements of the refractory disc were taken up in the slag, the majority of the $\mathrm{MgO}$ remained as a separate MO phase.

The changing of the magnesia refractory composition could cause it to lose structural integrity. It is therefore important that a freeze lining be maintained, even when operating at a slag basicity of 2.0 .

\subsubsection{Comparison of Modelling and Test Work Results}

For both smelting tests, the analyses of the slag matrix compared relatively well with the composition of the slag predicted by thermochemical modelling. However, for both tests, the CrO content of the slag matrix was considerably lower than that predicted by modelling. The $\mathrm{Cr}$ content of the alloy was also much higher. This indicates that the extent to which the reduction reactions occurred was higher than thermochemical modelling predicted. The reasons for this need to be identified by conducting further smelting tests to determine the mechanism by which the reactions occur.

The refractory disc which was placed in the mixture prior to the test was completely dissolved into the slag matrix for a target basicity of 1.5 and was partially worn for a target basicity of 2.0. These results are not surprising, as thermochemical modelling predicted the slag to only be saturated in $\mathrm{MgO}$ above a slag basicity of 1.99.

No passivating phase was found to have formed on any of the refractory surfaces. A slag freeze lining would therefore be required when operating within this basicity range.

\subsection{Implications for Industry}

The economic benefits, along with the lower $\operatorname{Cr}(\mathrm{VI})$ production rates, make the Furnace Method, particularly using liquid FeSiCr, a viable alternative to the Mixing Method. It has been shown that a lime fluxed slag with a basicity in the region of 1.70 would be compatible with a magnesia refractory. However, there are a number of aspects that should be considered before attempting to implement this process. As the slag only becomes saturated in $\mathrm{MgO}$ above a slag basicity of 1.99 , a slag freeze 
lining would be required to protect the refractories. The optimal batch feeding sequence is also critical to prevent the slag from solidifying in the furnace at the one extreme, and severely damaging the refractories at the other. A larger scale test campaign would be crucial for establishing the operating ranges prior to implementing such a project on commercial scale. 


\section{RECOMMENDATIONS FOR FUTURE WORK}

\subsection{Reaction Mechanism of Chromite Reduction}

Test work indicated that the $\mathrm{CrO}$ content of the slag was much lower and the $\mathrm{Cr}$ content of the alloy much higher than that predicted by thermochemical modelling. The extent to which reduction reactions occurred was therefore higher than predicted by the models. The alloy droplets were also mainly associated with the MO phase. In order to identify the reasons for this, further test work is required in which the specific reaction mechanisms are identified. These tests would need to determine the order in which different materials melt and react.

\subsection{Aluminium as Alternative to Ferrochrome Silicide}

Aluminium has been identified as an alternative reductant to silicon for the reduction of chromite. The disadvantage of aluminium is that, unlike for silicon (in the form of ferrochrome silicide), a facility for the production thereof is very capital intensive and is usually done on large scale. However, if a production facility is close to the low carbon ferrochrome facility, or if large quantities of recycle scrap is available, aluminium becomes viable as an alternative reductant.

For this reason, a similar study may be performed for aluminium as was done in this study for using silicon as reductant. Particular attention should be paid to the fluxing agents used to control the slag properties, as the slag system will be significantly different. An alumina lining will likely perform much better than a basic lining, but this may eliminate lime as a flux, as it would readily react with an alumina lining.

An advantage of using aluminium is that its density ( 2.7) is much lower than that ferrochrome silicide. Depending on the slag chemistry, the density may be very similar to that of aluminium. The aluminium feed may therefore be suspended in the slag and improve contact time with the chromite, thereby increasing recovery.

\subsection{Impurities in Furnace Method}

Minor components, such as phosphorous and sulphur were not considered in this study. However, there are also limits for these in the final product. Consideration should be given to where they report to.

During a campaign to run the LFFM on a commercial plant, for the little LC FeCr product that was produced, the plant personnel complained about having difficulty to crush the alloy. It is believed that the cocktailing step introduces nitrogen (from the air) into the alloy, which makes the alloy more brittle. Eliminating the need for cocktailing would therefore affect the friability of the alloy. 


\section{REFERENCES}

American Standards Tests for Materials, 2004. Shake extraction of solid waste with water, Method D 3987-85. PA, USA: ASTM.

Basson, J., Curr, T. \& Gericke, W., 2007. South Africa's ferroalloy industry - Present status and future outlook. New Delhi, International Committee of Ferro Alloys (ICFA), pp. 3 - 24.

Beukes, J., Dawson, N. \& Van Zyl, P., 2010. Theoretical and practical aspects of $\mathrm{Cr}(\mathrm{VI})$ in the South African ferrochrome industry. The Journal of the South African Institute of Mining and Metallurgy, Volume 110, pp. 743-750.

Beukes, J., Van Zyl, P. \& Ras, M., 2012. Treatment of $\mathrm{Cr}(\mathrm{VI})$-containing wastes in the South African ferrochrome industry - a review of currently applied methods. The Journal of the South African Institute of Mining and Metallurgy, Volume 112, pp. 347 352.

Bhonde, P., Ghodgaonkar, A. M. \& Angal, R. D., 2007. Various techniques to produce low carbon ferrochrome. New Delhi, The Indian Ferro Alloy Producers' Association, pp. 85-90.

Chirasha, J., 2011. Ferrochrome smelting and smelting capacity investment in Zimbabwe. Johannesburg, South African Institute of Mining and Metallurgy (SAIMM), pp. 77 - 82.

Dynamic Energy and Water Solutions, 2014. Kingdom of Saudi Arabia electricity tariffs. [Online]

Available at: http://www.dynamic-ews.com

[Accessed 10 December 2014].

Eskom, 2014. Schedule of standard prices for Eskom tariffs. [Online]

Available at: http://www.eskom.co.za

[Accessed 09 December 2014].

Eti Elektrometalurji A.S., 2014. Low Carbon Ferrochrome. [Online]

Available at: http://www.etimet.com/

[Accessed 04 December 2014].

European IPPC Bureau, 2001. Integrated pollution prevention and control (IPPC) reference document on best available technique in the non ferrous metals industry, Seville: European Commission.

Gasik, M., 2013. Technology of chromium and its ferroalloys. In: M. Gasik, ed. Handbook of Ferroalloys - Theory and Technology. Oxford: Butterworth-Heinemann, pp. 267-316.

Ghose, S., Nanda, J. K. \& Patel, B. B., 1983. Duplex process for production of low carbon ferrochrome. Jamsedpur, National Metallurgical Laboratory, pp. 215-217. 
Government of Western Australia, n.d.. Electricity prices. [Online] Available at: http://www.finance.wa.gov.au

[Accessed 09 December 2014].

Hawley, E., Deeb, R., Kavanaugh, M. \& Jacobs, J., 2005. Treatment technologies for Cr(VI). In: J. Guertin, ed. Chromium (VI) handbook. Boca Raton: CRC Press, pp. 275 $-310$.

Holappa, L. \& Xiao, Y., 2004. Slags in ferroalloy production - review of present knowledge. Journal of the South African Institute of Mining and Metallurgy, pp. 429438.

Humphreys, K. K., 2004. Process Product Manufacturing. In: Skills \& knowledge of cost engineering. Morgantown: AACE International, pp. $10.1-10.24$.

Jones, R., Reynolds, Q. G. \& Curr, T. R., 2011. Some myths about DC arc furnaces. Johannesburg, South African Institute of Mining and Metallurgy, pp. 15-32.

Kennedy, M., 2012. Electric slag furnace dimensioning. Orlando, The Minerals, Metals and Materials Society, pp. 279-290.

Kossyrev, K. \& Olsen, S. E., 1995. Silicon and carbon in chromium alloys. Trondheim, s.n., pp. 329 - 338.

Langård, S. \& Costa, M., 2007. Chromium. In: G. Nordberg, ed. Handbook on the toxicology of metals. London: Academic Press, pp. 487 - 510.

$\mathrm{Li}, \mathrm{H} ., 2015$. Ellingham diagram web project. [Online]

Available at: http://www.engr.sjsu.edu/ellingham/

[Accessed 29 June 2015].

Ma, G. \& Garbers-Craig, A., 2006. A review of the characteristics, formation mechanisms and treatment processes of $\mathrm{Cr}(\mathrm{VI})$-containing pyrometallurgical waste. The Journal of the South African Institute of Mining and Metallurgy, Volume 106, pp. 753-763.

Mulange, D. \& Garbers-Craig, A., 2012. Stabilization of $\mathrm{Cr}(\mathrm{VI})$ from fine ferrochrome dust using exfoliated vermiculite. Journal of Hazardous Materials, pp. 46-52.

Najm, I. et al., 2014. Impact of water quality on hexavalent chromium removal efficiency and cost, Denver: Water Research Foundation.

Occupational Safety and Health Administration, 2014. [Online]

Available at: https://www.osha.gov

[Accessed 26 July 2014].

PayScale Inc., 2015. Australia. [Online]

Available at: http://www.payscale.com/research/AU/Country=Australia/Salary

[Accessed 15 August 2015].

PayScale Inc., 2015. South Africa. [Online]

Available at: http://www.payscale.com/research/ZA/Country=South Africa/Salary [Accessed 15 August 2015]. 
Perrin, R., 1937. Process for the manufacture of metal alloys. United States, Patent No. 2100265.

Pretorius, E., 2010. Fundamentals of EAF and ladle slags and ladle refining principles. [Online]

Available at: http://etech.Iwbref.com/Downloads/Theory

[Accessed 09 January 2015].

Pretorius, E. \& Muan, A., 1992. Activity-composition relations of chromium oxide in silicate melts at $1500^{\circ} \mathrm{C}$ under strongly reducing conditions. Journal of the American Ceramic Society, pp. 1364-1377.

Robiette, A., 1973. Electric smelting processes. London: Charles Griffin \& Company Limited.

Smith, H., Denton, G. M. \& Barcza, N. A., 1996. Ferrochromium production. South Africa, Patent No. 96/0877.

Steelonthenet.com, 2014. Met Coke Prices 2008-2014. [Online]

Available at: http://www.steelonthenet.com

[Accessed 05 December 2014].

Tangstad, M., Ksiazek, M., Andersen, V. \& Ringdalen, E., 2010. Small scale laboratory experiments simulating an industrial silicon furnace. Helsinki, Outotec Oyj, pp. 661-669.

Verein Deutscher Eisenhüttenleute (VDEh), 2008. Slag atlas, 2nd Edition.

Düsseldorf: Verlag Stahleisen $\mathrm{GmbH}$.

World Health Organization, 2004. Chromium in drinking-water. [Online]

[Accessed 3 July 2015]. 


\section{APPENDIX A: PERSONNEL LISTS}

Table 45: Operational personnel requirements.

\begin{tabular}{|c|c|c|c|c|c|c|}
\hline \multicolumn{7}{|c|}{ OPERATIONAL PERSONNEL } \\
\hline DESCRIPTION & GRADE & $\begin{array}{l}\text { QTY PER } \\
\text { SHIFT }\end{array}$ & SHIFT BASIS & No Req & $\begin{array}{c}\text { Total Cost } \\
\text { (Annual) - RSA }\end{array}$ & $\begin{array}{c}\text { Total Cost } \\
\text { (Annual) - AUS }\end{array}$ \\
\hline \multicolumn{7}{|l|}{ 1. GENERAL } \\
\hline Plant Engineering Manager & B & 1 & 1 & 1 & USD 131794 & USD 277982 \\
\hline Plant Production Manager & B & 1 & 1 & 1 & USD 131794 & USD 277982 \\
\hline HSE Manager & C & 1 & 1 & 1 & USD 72474 & USD 171932 \\
\hline HSE Officer & $\mathrm{E}$ & 1 & 1 & 1 & USD 21704 & USD 89298 \\
\hline \multicolumn{2}{|l|}{ TOTAL GENERAL } & & & 4 & USD 357767 & USD 817194 \\
\hline \multicolumn{7}{|l|}{ 2. FURNACE PLANT } \\
\hline General Foreman & D & 1 & 4 & 4 & USD 140340 & USD 395299 \\
\hline Furnace Operator (Control Room) & $E$ & 4 & 4 & 16 & USD 347266 & USD 1428769 \\
\hline Raw Materials Batching (Control Room) & $E$ & 2 & 4 & 8 & USD 173633 & USD 714385 \\
\hline Electrode Installation & $\mathrm{F}$ & 4 & 4 & 16 & USD 166022 & USD 1042894 \\
\hline Roaming Operators & $\mathrm{F}$ & 4 & 4 & 16 & USD 166022 & USD 1042894 \\
\hline Tapping & $\mathrm{E}$ & 12 & 4 & 48 & USD 1041797 & USD 4286308 \\
\hline \multicolumn{2}{|l|}{ TOTAL FURNACES } & & & 108 & USD 2035079 & USD 8910550 \\
\hline \multicolumn{7}{|l|}{ 3. CASTING BAY } \\
\hline Crane operator & $\mathrm{F}$ & 2 & 4 & 8 & USD 83011 & USD 521447 \\
\hline Casting bay preparation & $\mathrm{F}$ & 2 & 4 & 8 & USD 83011 & USD 521447 \\
\hline Cleaning operators & $\mathrm{F}$ & 4 & 4 & 16 & USD 166022 & USD 1042894 \\
\hline \multicolumn{2}{|l|}{ TOTAL CASTING BAY } & & & 32 & USD 332045 & USD 2085788 \\
\hline \multicolumn{7}{|l|}{ 4. LABORATORY } \\
\hline Plant Metallurgists & $\mathrm{D}$ & 1 & 1 & 1 & USD 35085 & USD 98825 \\
\hline Laboratory Supervisor & $D$ & 1 & 1 & 1 & USD 35085 & USD 98825 \\
\hline Laboratory Analysts & $\mathrm{E}$ & 2 & 4 & 8 & USD 173633 & USD 714385 \\
\hline Sample Assistants & $\mathrm{F}$ & 2 & 4 & 8 & USD 83011 & USD 521447 \\
\hline Cleaner & G & 2 & 1 & 2 & USD 12193 & USD 86305 \\
\hline \multicolumn{2}{|l|}{\begin{tabular}{|l} 
TOTAL LABORATORY \\
\end{tabular}} & & & 20 & USD 339006 & USD 1519786 \\
\hline \multicolumn{7}{|l|}{ 5. SERVICES } \\
\hline Supervisor (Raw Mat \& Final Product) & $\mathrm{D}$ & 1 & 1 & 1 & USD 35085 & USD 98825 \\
\hline Plant Operators (Raw Material handling) & $\mathrm{E}$ & 4 & 4 & 16 & USD 347266 & USD 1428769 \\
\hline Plant Operators (Final Product) & $\mathrm{E}$ & 2 & 4 & 2 & USD 43408 & USD 178596 \\
\hline Plant Cleaners/Relief & $\mathrm{G}$ & 4 & 1 & 4 & USD 24385 & USD 172609 \\
\hline Weigh Bridge Clerk & $E$ & 2 & 4 & 8 & USD 173633 & USD 714385 \\
\hline Water treatment & $\mathrm{F}$ & 2 & 4 & 8 & USD 83011 & USD 521447 \\
\hline \multicolumn{2}{|l|}{ TOTAL SERVICES } & & & 39 & USD 706788 & USD 3114631 \\
\hline \multicolumn{7}{|l|}{ 6. STORES } \\
\hline Storeman & $\mathrm{F}$ & 1 & 1 & 1 & USD 10376 & USD 65181 \\
\hline Store assistants & $\mathrm{F}$ & 1 & 1 & 1 & USD 10376 & USD 65181 \\
\hline Procurement officers/ buyers & E & 1 & 1 & 1 & USD 21704 & USD 89298 \\
\hline Forklift driver / handler & $\mathrm{F}$ & 1 & 1 & 1 & USD 10376 & USD 65181 \\
\hline Cleaner & $\mathrm{G}$ & 1 & 1 & 1 & USD 6096 & USD 43152 \\
\hline \multicolumn{2}{|l|}{ TOTAL STORES } & & & 5 & USD 58930 & USD 327993 \\
\hline \multicolumn{2}{|l|}{ 7. LEAVE ALLOW ANCE (ANNUAL \& SICK) } & $7 \%$ & & & USD 268073 & USD 1 174316 \\
\hline \multicolumn{2}{|l|}{ 8. TOTAL PERMANENT COMPLEMENT (INCL LEAVE) } & & & 208 & USD 4097687 & USD 17950259 \\
\hline \multicolumn{7}{|l|}{ 9. CONTRACTORS } \\
\hline \multicolumn{2}{|l|}{ Mobile Equipment Operators } & 4 & 4 & 4 & USD 41506 & USD 260724 \\
\hline First Aid Station & E & 2 & 4 & 8 & USD 173633 & USD 714385 \\
\hline Fire Station & $\mathrm{E}$ & 2 & 4 & 8 & USD 173633 & USD 714385 \\
\hline \multicolumn{2}{|l|}{ TOTAL CONTRACTED COMPLEMENT } & & & 20 & USD 388771 & USD 1689493 \\
\hline \multicolumn{7}{|l|}{ 10. PLANT TOTAL } \\
\hline Normal Complement & & & & 208 & USD 4097687 & USD 17950259 \\
\hline Contracted Complement & & & & 20 & USD 388771 & USD 1689493 \\
\hline TOTAL & & & & 228 & USD 4486459 & USD 19639752 \\
\hline
\end{tabular}


Table 46: Administrative and other personnel requirements.

\begin{tabular}{|c|c|c|c|c|c|c|}
\hline \multicolumn{7}{|c|}{ ADMINISTRATIVE AND OTHER PERSONNEL } \\
\hline DESCRIPTION & GRADE & $\begin{array}{l}\text { QTY PER } \\
\text { SHIFT }\end{array}$ & SHIFT BASIS & No Req & $\begin{array}{c}\text { Total Cost } \\
\text { (Annual) - RSA }\end{array}$ & $\begin{array}{c}\text { Total Cost } \\
\text { (Annual) - AUS }\end{array}$ \\
\hline \multicolumn{7}{|l|}{ 1. GENERAL } \\
\hline General Director (CEO) & A & 1 & 1 & 1 & USD 213602 & USD 361904 \\
\hline Secretary to general manager & $\mathrm{E}$ & 1 & 1 & 1 & USD 21704 & USD 119771 \\
\hline Clerks & $\mathrm{F}$ & 1 & 1 & 1 & USD 10376 & USD 71392 \\
\hline TOTAL GENERAL & & & & 3 & USD 245682 & USD 553067 \\
\hline \multicolumn{7}{|l|}{ 2. FINANCE AND ADMINISTRATION } \\
\hline Finance \& Admin manager & B & 1 & 1 & 1 & USD 131794 & USD 277982 \\
\hline Accounts manager & C & 1 & 1 & 1 & USD 72474 & USD 171932 \\
\hline Salaries supervisor & E & 1 & 1 & 1 & USD 21704 & USD 119771 \\
\hline IT Supervisor & D & 1 & 1 & 1 & USD 35085 & USD 89369 \\
\hline IT Technicians & E & 1 & 1 & 1 & USD 21704 & USD 119771 \\
\hline Accounts clerks & $\mathrm{F}$ & 1 & 1 & 1 & USD 10376 & USD 71392 \\
\hline Receptionist & $\mathrm{F}$ & 1 & 1 & 1 & USD 10376 & USD 71392 \\
\hline TOTAL FINANCE AND ADMIN & & & & 7 & USD 303513 & USD 921609 \\
\hline \multicolumn{7}{|l|}{ 3. HUMAN RESOURCES } \\
\hline Manpower manager & C & 1 & 1 & 1 & USD 72474 & USD 171932 \\
\hline Training officer & D & 1 & 1 & 1 & USD 35085 & USD 89369 \\
\hline Clerk & $\mathrm{F}$ & 1 & 1 & 1 & USD 10376 & USD 71392 \\
\hline TOTAL HUMAN RESOURCES & & & & 3 & USD 117935 & USD 332693 \\
\hline \multicolumn{7}{|l|}{ 4. MARKETING } \\
\hline Marketing manager & B & 1 & 1 & 1 & USD 131794 & USD 277982 \\
\hline Clerks & $\mathrm{F}$ & 1 & 1 & 1 & USD 10376 & USD 71392 \\
\hline \multicolumn{2}{|l|}{ TOTAL MARKETING } & & & 2 & USD 142170 & USD 349374 \\
\hline \multicolumn{2}{|l|}{ 7. LEAVE ALLOW ANCE (ANNUAL \& SICK) } & $7 \%$ & & & USD 56651 & USD 150972 \\
\hline \multicolumn{2}{|l|}{ 8. TOTAL PERMANENT COMPLEMENT(INCL LEAVE) } & & & 15 & USD 865951 & USD 2307715 \\
\hline \multicolumn{7}{|l|}{ 9. CONTRACTED PERSONNEL } \\
\hline Security Guards & $\mathrm{F}$ & 2 & 4 & 8 & USD 10376 & USD 71392 \\
\hline Security Officer & E & 1 & 1 & 1 & USD 21704 & USD 119771 \\
\hline Cleaners & $\mathrm{G}$ & 12 & 4 & 48 & USD 6096 & USD 43152 \\
\hline \multicolumn{2}{|l|}{ TOTAL CONTRACTED COMPLEMENT } & & & 57 & USD 38176 & USD 234315 \\
\hline \multicolumn{7}{|l|}{ 10. PLANT TOTAL } \\
\hline \multicolumn{4}{|l|}{ Normal Complement } & 15 & USD 865951 & USD 2307715 \\
\hline \multicolumn{4}{|l|}{ Contracted Complement } & 57 & USD 38176 & USD 234315 \\
\hline \multicolumn{4}{|l|}{ TOTAL } & 72 & USD 904127 & USD 2542030 \\
\hline
\end{tabular}




\section{APPENDIX B: THERMOCHEMICAL MODELLING METHODOLOGY}

FactSage 6.4 was used for all thermochemical modelling.

The 'Equilib' module was used to determine the equilibrium products, using the 'FToxid', 'FactPS' and 'SGTE' databases. Ideal gases, pure solids and solution species were considered as possible reaction products. All solution species were included that contained the components present in the raw materials.

\section{Develop Standard Mixtures}

Mixtures were made for each of the raw materials used in the models, using FactSage's 'Mixture' function. The chromite analysis was the same as that specified in Table 12, the FeSiCr as specified in Table 3 and doloma as in Table 21. Lime, magnesia and quartz were considered to be pure $\mathrm{CaO}, \mathrm{MgO}$ and $\mathrm{SiO}_{2}$. The temperatures of the chromite and doloma were $25^{\circ} \mathrm{C}$, while the $\mathrm{FeSiCr}$ had a temperature of $1600^{\circ} \mathrm{C}$. This is slightly higher than the $1550^{\circ} \mathrm{C}$ used in the preliminary mass and energy balances. However, the purpose of the thermochemical models was not to do an energy balance, but only to determine the equilibrium compositions of the different phases.

\section{Calculation of Reaction Products}

All calculations for the reaction products were done at $1750^{\circ} \mathrm{C}$ and 1 atmosphere.

$100 \mathrm{~g}$ of chromite was used as the basis for the models. The flux (lime or doloma) and FeSiCr additions were iterated until the required basicity target and chrome oxide content in the slag (5 to 6\%) was reached. For the acidic system, quartz additions of $10,20,30,40$ and 100 grams were added, as the basicity target was unknown. The amounts of raw materials used in the models are shown in Tables 27, 29 and 31.

After calculation of each of the equilibrium models, the slag products were saved as mixtures, for use in the refractory-slag interaction models.

\section{Calculation of Liquidus Temperatures}

After determining the required feed ratios, the same equilibrium models were used to determine the liquidus temperatures of the different slags. Temperature limits of 1200 and $2400^{\circ} \mathrm{C}$ were used and the 'Transitions' option selected to determine when the slag would be completely molten. 


\section{Refractory and Slag Interactions}

As mentioned, each of the slag products from the equilibrium models was saved as mixtures. 100 grams of refractory (pure $\mathrm{MgO}$ or doloma) was used as the basis for the models. Each of the slag mixtures was added to the refractory in increments of 10 grams, from 0 to 200 grams.

The phase distributions from the models were exported to Excel spreadsheets and the total slag at equilibrium, as a percentage of the total mass in the system, was plotted as a function of the fraction of slag added to the refractories. The slag added to the system, as a percentage of the total mass in the system, was also plotted to indicate the stability limit.

Additionally, the mass of solid $\mathrm{MgO}$, as a percentage of the total system mass, was plotted as a function of the fraction of slag added to the refractories for the magnesia refractory system. A stability limit was also plotted to determine the slag basicity at which the slag would be saturated in $\mathrm{MgO}$.

\section{Operating Methodology Calculations}

Thermochemical models were developed to investigate how the slag basicity would change when either feeding FeSiCr into an ore-lime melt, or when feeding an orelime mixture into molten FeSiCr. The same ore, lime and $\mathrm{FeSiCr}$ feed ratios were used as for the earlier models for determining the reaction products.

All calculations for the operating methodology were done at $1750^{\circ} \mathrm{C}$ and 1 atmosphere.

\section{Feeding FeSiCr into an Ore-Lime Melt}

All of the ore-lime mixture was used in the model, but the FeSiCr was added incrementally in steps of $10 \%$, from $0 \%$ up to $100 \%$ of the mass determined by the earlier models. The equilibrium slag basicity for each step was plotted as a function of the percentage of FeSiCr added to the system.

\section{Feeding an Ore-Lime Melt into FeSiCr}

All of the FeSiCr was used in the model, but the ore-lime mixture was added incrementally in steps of $10 \%$, from $0 \%$ up to $100 \%$ of the mass determined by the earlier models. The equilibrium slag basicity for each step was plotted as a function of the percentage of the ore-lime added to the system.

As the basicity was found to start off lower than the targeted value, the silicon and magnesium in the alloy was also plotted as a function of the percentage of the orelime added. This was done to determine the reason for the low basicity, as well as to identify the products that would form. 


\section{APPENDIX C: TEST WORK ANALYSES}

Table 47: Slag matrix $(B=1.5)$.

\begin{tabular}{|l|r|r|r|r|r|r|r|r|}
\hline & Set 4 & Set 5 & Set 6 & Set 20 & Set 21 & Set 23 & Set 24 & Set 25 \\
\hline $\mathrm{Al}_{2} \mathrm{O}_{3}$ & 11.99 & 12.95 & 9.71 & 7.54 & 0.51 & 12.00 & 10.34 & 10.57 \\
\hline $\mathrm{CaO}$ & 35.84 & 35.40 & 32.54 & 34.89 & 32.74 & 34.45 & 34.03 & 35.25 \\
\hline $\mathrm{CrO}$ & 1.33 & - & 1.21 & - & 1.21 & - & 1.44 & 1.01 \\
\hline $\mathrm{MgO}$ & 16.29 & 17.01 & 21.13 & 21.46 & 27.66 & 18.19 & 18.28 & 17.69 \\
\hline $\mathrm{SiO}_{2}$ & 34.56 & 34.63 & 35.41 & 36.11 & 37.87 & 35.36 & 35.90 & 35.47 \\
\hline Total & 100.01 & 99.99 & 100.00 & 100.00 & 99.99 & 100.00 & 99.99 & 99.99 \\
\hline & Set 26 & Set 27 & Set 28 & Set 29 & Set 42 & Set 43 & Set 44 & \\
\hline $\mathrm{Al}_{2} \mathrm{O}_{3}$ & 10.36 & 11.34 & 10.41 & 10.25 & 7.06 & 0.90 & 15.05 \\
\hline $\mathrm{CaO}$ & 34.79 & 35.16 & 33.78 & 34.84 & 37.37 & 32.56 & 37.98 & - \\
\hline $\mathrm{CrO}$ & - & - & - & 1.74 & & 1.19 & & - \\
\hline $\mathrm{MgO}$ & 18.47 & 17.60 & 19.50 & 17.16 & 15.57 & 26.79 & 11.33 \\
\hline $\mathrm{SiO}$ & 36.37 & 35.90 & 36.31 & 36.02 & 40.00 & 38.56 & 35.64 \\
\hline $\mathrm{Total}_{2}$ & 99.99 & 100.00 & 100.00 & 100.01 & 100.00 & 100.00 & 100.00 \\
\hline
\end{tabular}

Table 48: Slag matrix $(B=2.0)$.

\begin{tabular}{|c|c|c|c|c|c|c|c|c|c|c|c|}
\hline & Set 47 & Set 48 & Set 49 & Set 55 & Set 56 & Set 57 & Set 63 & Set 64 & Set 65 & Set 71 & Set 72 \\
\hline $\mathrm{Al}_{2} \mathrm{O}_{3}$ & 10.08 & 17.00 & 29.05 & 16.56 & 7.20 & 24.35 & 27.31 & 3.78 & 5.47 & 7.28 & 9.56 \\
\hline $\mathrm{CaO}$ & 44.51 & 42.58 & 37.29 & 40.23 & 45.65 & 36.49 & 37.99 & 47.84 & 46.74 & 46.64 & 44.86 \\
\hline $\mathrm{MgO}$ & 12.75 & 9.10 & 8.80 & 13.46 & 13.47 & 12.52 & 10.44 & 12.80 & 13.44 & 12.31 & 13.75 \\
\hline $\mathrm{SiO}_{2}$ & 32.66 & 31.32 & 24.86 & 29.75 & 33.68 & 26.63 & 24.27 & 35.59 & 34.35 & 33.76 & 31.83 \\
\hline Total & 100.00 & 100.00 & 100.00 & 100.00 & 100.00 & 99.99 & 100.01 & 100.01 & 100.00 & 99.99 & 100.00 \\
\hline
\end{tabular}

Page 122 
Table 49: $M O$ solid solution ( $B=1.5)$.

\begin{tabular}{|c|c|c|c|c|c|c|c|c|c|c|}
\hline & Set 7 & Set 8 & Set 9 & Set 15 & Set 16 & Set 17 & Set 18 & Set 34 & Set 35 & Set 36 \\
\hline $\mathrm{Al}_{2} \mathrm{O}_{3}$ & 1.08 & 1.54 & 0.92 & 0.84 & 1.65 & - & 1.30 & 2.47 & 1.15 & 1.35 \\
\hline $\mathrm{CaO}$ & - & - & - & - & - & - & 0.64 & - & - & - \\
\hline $\mathrm{CrO}$ & 4.07 & 3.70 & 3.38 & 2.35 & 3.26 & 3.37 & 3.16 & 6.05 & 4.30 & 4.95 \\
\hline $\mathrm{MgO}$ & 94.47 & 94.76 & 95.69 & 96.81 & 95.09 & 96.63 & 94.90 & 91.48 & 94.55 & 93.70 \\
\hline Total & 99.61 & 100.00 & 100.00 & 100.00 & 100.00 & 100.00 & 100.00 & 100.00 & 100.00 & 100.00 \\
\hline
\end{tabular}

Table 50: $M O$ solid solution $(B=2.0)$.

\begin{tabular}{|l|r|r|r|r|r|r|r|r|}
\hline & Set 58 & Set 59 (outlier) & Set 60 & Set 66 & Set 67 & Set 68 & Set 74 & Set 75 \\
\hline $\mathrm{CaO}$ & 0.51 & 32.97 & 0.42 & 0.47 & 0.47 & 0.41 & 0.32 & 0.33 \\
\hline $\mathrm{CrO}$ & 0.24 & - & 0.34 & 0.56 & 1.42 & 0.55 & 0.75 & 1.33 \\
\hline $\mathrm{FeO}$ & - & 3.79 & - & - & - & - & - & - \\
\hline $\mathrm{MgO}$ & 99.25 & 14.69 & 99.24 & 98.97 & 98.11 & 99.04 & 98.93 & 98.34 \\
\hline $\mathrm{SiO}_{2}$ & - & 48.55 & - & - & - & - & - & - \\
\hline Total & 100.00 & 100.00 & 100.00 & 100.00 & 100.00 & 100.00 & 100.00 & 100.00 \\
\hline
\end{tabular}


Table 51: Alloy ( $B=1.5)$.

\begin{tabular}{|l|r|r|r|r|r|r|r|}
\hline wt\% & Set 1 & Set 2 & Set 3 & Set 12 & Set 13 & Set 14 & Set 19 \\
\hline $\mathrm{Cr}$ & 70.45 & 73.92 & 74.67 & 76.33 & 73.62 & 74.52 & 72.83 \\
\hline $\mathrm{Fe}$ & 29.16 & 25.67 & 24.98 & 23.28 & 24.77 & 25.12 & 26.52 \\
\hline $\mathrm{Mg}$ & - & - & - & - & 1.26 & - & - \\
\hline $\mathrm{Si}$ & 0.39 & 0.40 & 0.35 & 0.38 & 0.35 & 0.36 & 0.65 \\
\hline Total & 100.00 & 99.99 & 100.00 & 99.99 & 100.00 & 100.00 & 100.00 \\
\hline
\end{tabular}

Table 52: Alloy $(B=2.0)$.

\begin{tabular}{|l|r|r|r|r|r|r|r|r|}
\hline wt\% & Set 53 & Set 54 & Set 61 & Set 62 & Set 69 & Set 70 & Set 77 & Set 78 \\
\hline $\mathrm{Al}$ & - & - & - & - & 0.14 & - & - & - \\
\hline $\mathrm{Ca}$ & - & 0.16 & - & - & 0.84 & 0.20 & - & - \\
\hline $\mathrm{Cr}$ & 59.46 & 95.84 & 77.71 & 91.32 & 59.99 & 75.42 & 71.69 & 94.08 \\
\hline $\mathrm{Fe}$ & 31.57 & 1.72 & 17.72 & 5.40 & 33.65 & 21.20 & 26.07 & 3.37 \\
\hline $\mathrm{Mg}$ & - & - & - & - & 3.36 & - & - & - \\
\hline $\mathrm{Mn}$ & 1.41 & - & - & - & - & - & - & - \\
\hline $\mathrm{P}$ & 3.99 & 1.14 & - & - & 0.47 & 1.04 & 0.42 & - \\
\hline $\mathrm{Si}$ & 2.65 & - & 4.57 & 2.98 & 1.55 & 2.13 & 1.83 & 2.28 \\
\hline $\mathrm{Ti}$ & 0.92 & 0.54 & - & - & - & - & - & - \\
\hline $\mathrm{V}$ & 100.00 & 100.00 & 100.00 & 100.00 & 100.00 & 100.00 & 100.01 & 100.00 \\
\hline Total & & & - & & - & & - & 0.27 \\
\hline
\end{tabular}


Table 53: Slag that penetrated into magnesia crucible $(B=1.5)$.

\begin{tabular}{|l|r|r|r|r|r|r|r|}
\hline & Set 30 & Set 31 & Set 32 & Set 33 & Set 39 & Set 40 & Set 41 \\
\hline $\mathrm{Al}_{2} \mathrm{O}_{3}$ & 6.75 & 39.47 & 1.10 & 0.84 & 1.30 & - & 3.02 \\
\hline $\mathrm{CaO}$ & 19.57 & 14.19 & 30.50 & 30.89 & 20.77 & 48.81 & 30.14 \\
\hline $\mathrm{CrO}$ & 1.49 & 8.50 & - & - & 1.00 & - & - \\
\hline $\mathrm{MgO}$ & 44.54 & 24.22 & 29.45 & 29.66 & 44.54 & 13.93 & 29.19 \\
\hline $\mathrm{SiO}_{2}$ & 27.65 & 13.62 & 38.95 & 38.61 & 32.39 & 37.27 & 37.65 \\
\hline Total & 100.00 & 100.00 & 100.00 & 100.00 & 100.00 & 100.01 & 100.00 \\
\hline
\end{tabular}

Table 54: Refractory crucible ( $B=1.5)$.

\begin{tabular}{|l|r|r|r|}
\hline & Set 22 & Set 37 & Set 38 \\
\hline $\mathrm{Al}_{2} \mathrm{O}_{3}$ & 1.41 & 1.21 & - \\
\hline $\mathrm{CaO}$ & 2.63 & - & - \\
\hline $\mathrm{CrO}$ & 1.08 & 4.67 & 1.63 \\
\hline $\mathrm{MgO}$ & 91.90 & 94.13 & 98.37 \\
\hline $\mathrm{SiO}_{2}$ & 2.98 & - & - \\
\hline Total & 100.00 & 100.01 & 100.00 \\
\hline
\end{tabular}

Table 55: Refractory disc $(B=2.0)$.

\begin{tabular}{|l|r|r|r|}
\hline & Set $\mathbf{5 0}$ & Set $\mathbf{5 1}$ & Set $\mathbf{5 2}$ \\
\hline $\mathrm{CaO}$ & 0.28 & 0.38 & 0.38 \\
\hline $\mathrm{CrO}$ & - & 0.60 & 0.56 \\
\hline $\mathrm{MgO}$ & 99.72 & 99.02 & 99.06 \\
\hline Total & 100.00 & 100.00 & 100.00 \\
\hline
\end{tabular}

